\title{
استحالة النجس إلى طاهر للانتفاع به فى الفقه الإسلامى
}

\author{
إعداد \\ د.عبده السيد أحمد الثريف \\ مدرس الفقه بكلية الثريعة والثقانون بدمنهور \\ جامعة الأزهر
}

مجلة الاراسات التربوية والإنسانية ـ كلية التربية ـ ـ جامعة دمنهور

المجلد الخامس العدد(4) - الجزء الثالث- لسنة 2013 
استحالة النجس إلى طاهر للاتنفاع به فى الفقه الإسلاهى د.عبده السيد أحمد الثريف 


\section{بسم الله الرحمن الرحيم}

\section{ثقديم}

الحمد الله الذى أمرنا بالعبادة، وبطاعته وطاعة رسله، وو عدنا بالحسنى مــع الزيادة، و الصلاة و السلام على سيدنا محمد، البالغ منتهى الثــرف و الســيادة، و على آله وصحبه الذين منحهم الله العزة و السعادة، اللهم صلى وسلم وبـــارك مكئ عليه و على آله وصحبه، ومن تبعهم بإحسان إلى يوم الدين.

$$
\text { وبعد: }
$$

فالشريعة الإسلامية الغر اء صالحة لكل زمان ومكان، و هذا ليس شعار اً يطلق أو عبارة مرسلة تقال دون دليل أو برهان، أو مسألة افتر اضية لم ير الواقع لها

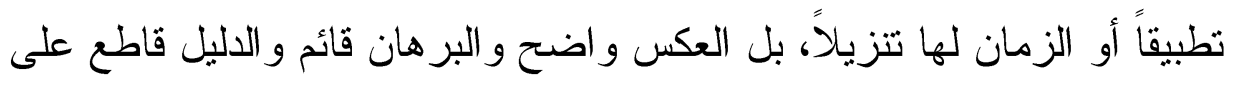

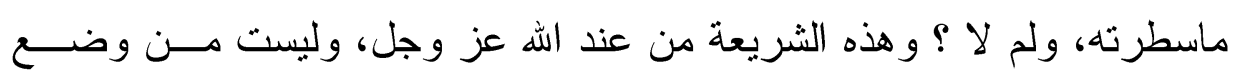
بشر يخطئ ويصيب، وقد يحكمه هو اه، فيحيد به عن الصواب، ويهوى به فى دركات الضالدل و البعد عن طريق الرشد و الهداية. ومن هنا فقد فاق الفقه الإسلامى الأنظمة الحديثة فى التعامل مع أحوال الناس

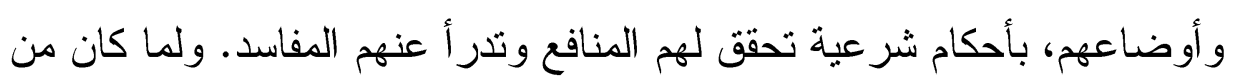
الأمور المستحدثة فى عصرنا اليوم، مالحق بأمور الناس من مستجدات، دفعت ونت

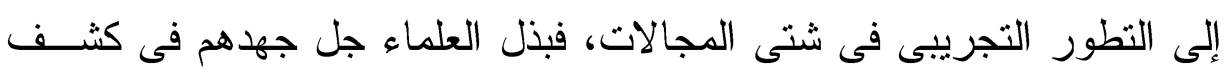

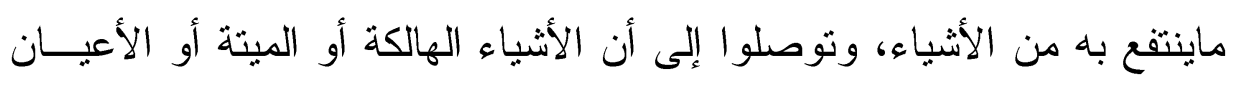

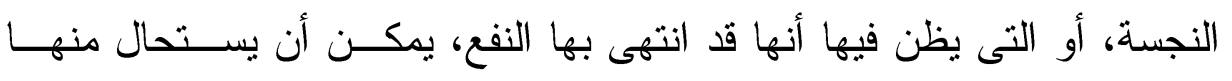
مايفيد، أو يحول بعض أجزائها إلى ماينفع مــن خــلال التطبيقــات العلميـــة و الاكتشافات الحديثة، ويلاحظ هنا أن العلم الحديث قد راعى أن الاستفادة مسن فـن الأشياء مع ندرتها هى من أسس تقدمه، وأن أحوال الناس تعــد مــن لبنــات الأطان، و هذا ليس ببعيد عن الفقه الإسلامى، بل هو الذى لفت أنظار هــــــاء

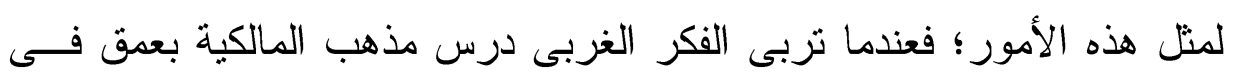
223 
العصور الوسطى، أيام ازدهار الحضارة الإسلامية فــى الأنــلس، وماأيسـام

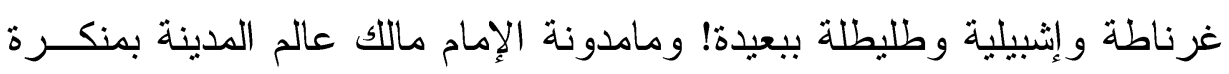

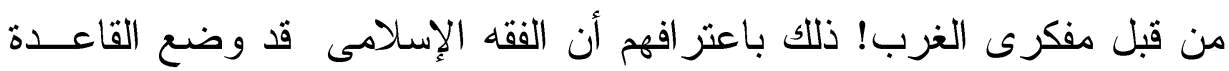

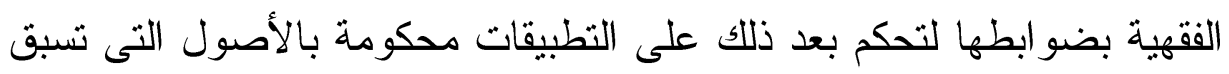

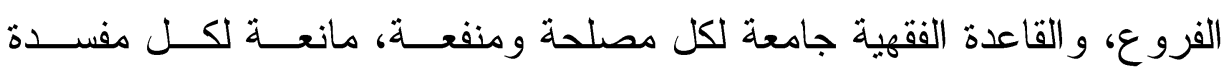

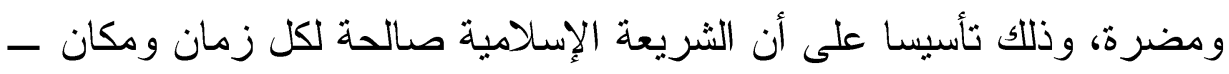

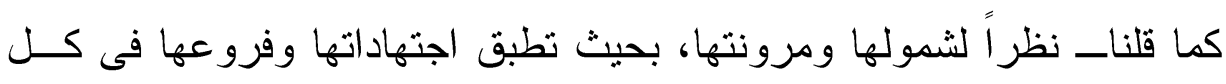

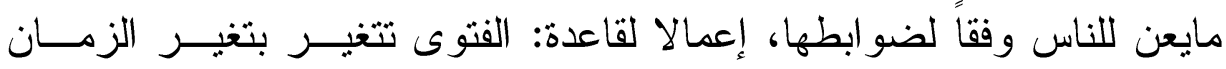

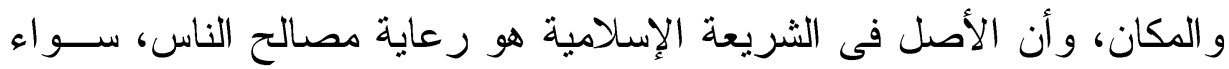
كانت بحفظ الضروريات أو الحاجيات أو التحسينيات، وكلها مقاصد شرعية.

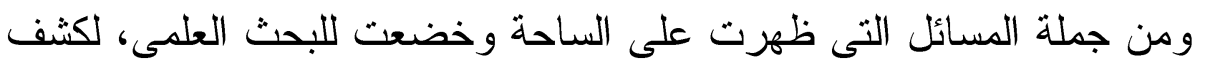

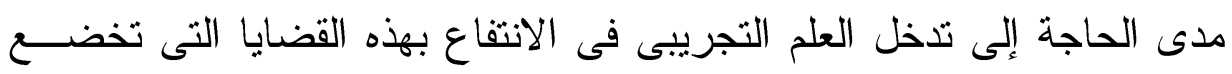

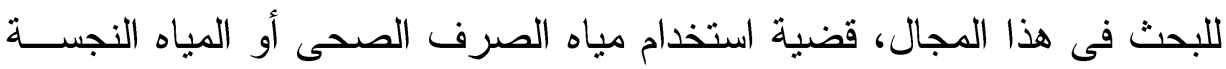

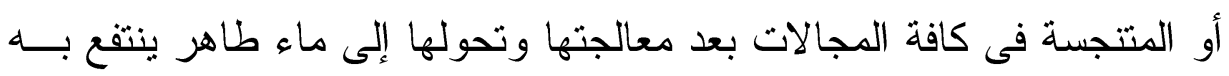

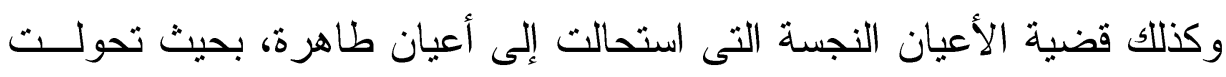

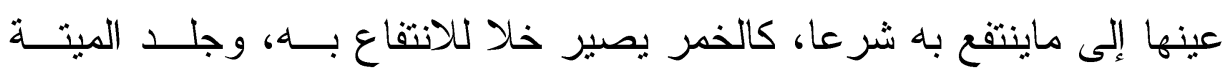

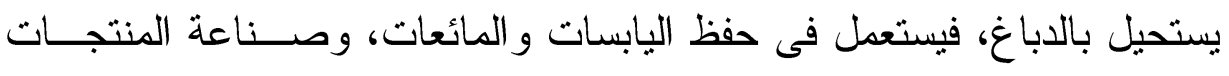

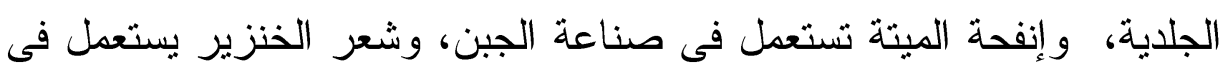

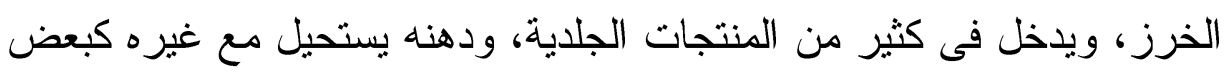
الكيماويات ليستعمل كمر اهم وكريمات ومعاجين لتنظيف الأسنان وغير ذلك.

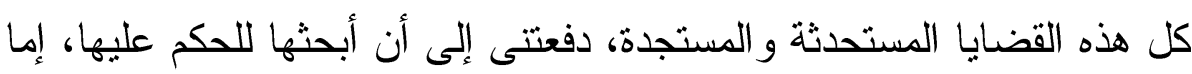

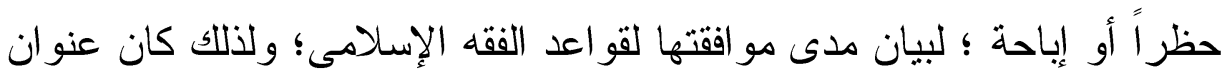
هذا البحث:" استحالة النجس إلى طاهر للانتفاع به فى الفقه الإسلامى". 
وسوف أسير بإذن الله تعالى فى هذا البحث على الخطوات الآتية:

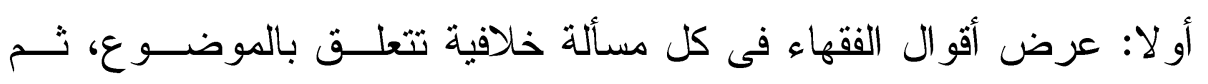

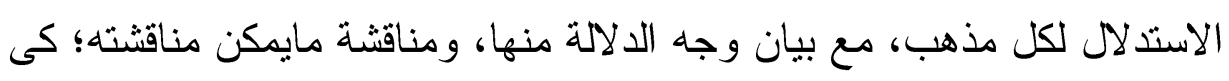

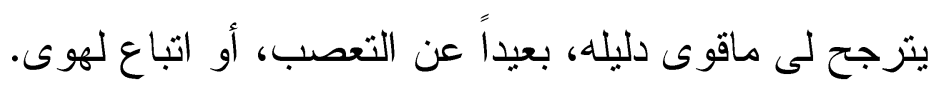

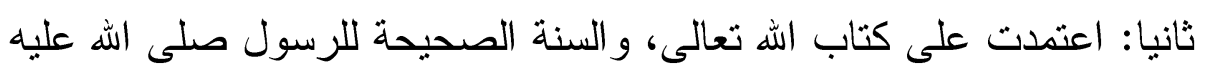

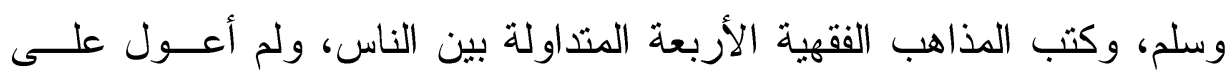
غير ها إلا نادر اً.

ثالثا: عزوت الآيات القر آنية إلى مواضعها من كتاب الله عز وجل، وخرجت الأحاديث النبوية من المصادر التى عنيت بذلك. وقد قسمت خطتى فى هذا البحث إلى مقدمة، وأربعة مباحث، وخاتمة.

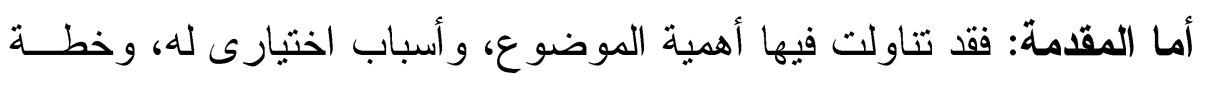
البحث و الار اسة. فأما المبحث الأول: ففى الطهارة فى الثريعة الإسلامية.

$$
\text { وقسمته إلى مطلبين: }
$$

المطلب الأول: ماهية و أهمية الطهارة فيى الشريعة الإسلامية. المطلب الثانى: عناية الشريعة الإسلامية بالنظافة. و أما المبحث الثانى: ففى مفهوم الاستحالة وتكيبفها الفقهى.

$$
\begin{aligned}
& \text { وقسمته إلى مطلبين: } \\
& \text { المطلب الأول: مفهوم الاستحالة. } \\
& \text { المطلب الثانى: تكييف الاستحالة فقها. }
\end{aligned}
$$

و أما المبحث الثالث: ففى استحالة المياه النجسة إلى طاهرة للانتفاع بها فــى الفقه الإسلامىى 
وقسمته إلى ثلاثة مطالب:

المطلب الأول: الوسائل التقليدية التى يتم بهـــا اســتحالة الميــاه

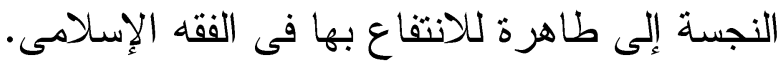

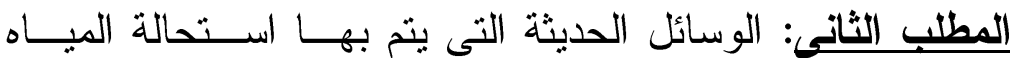
النجسة إلى طاهرة للانتفاع بها.

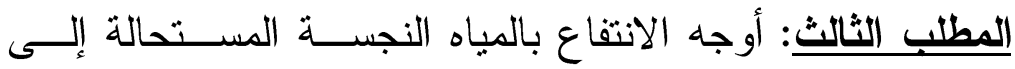
طاهرة بالطرق الحديثة فى منظور الفقه الإسلامى.

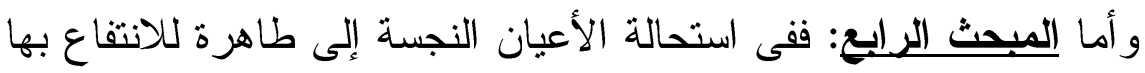
وقسمتها إلى أربعة مطالب: الإسلامى. المطلب الأول: استحالة الخمر إلى طاهرة للانتفاع بها فى الفقه الإسلامى.

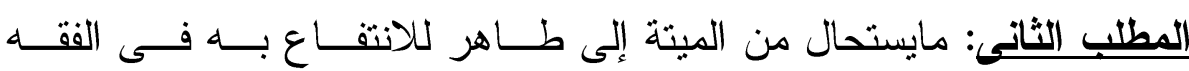
الإسلامىى. المطلب الثالث: موقف الفقه الإسلامى من الانتفاع بالخنزير فيما سوى اللحم. المطلب الرابع: موقف الفقه الإسلامى من الانتفاع بالدم المسفوح.

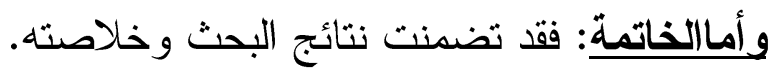

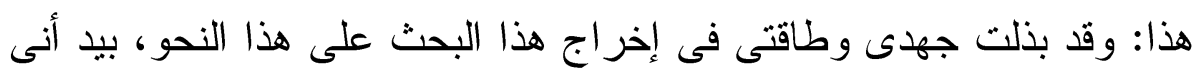

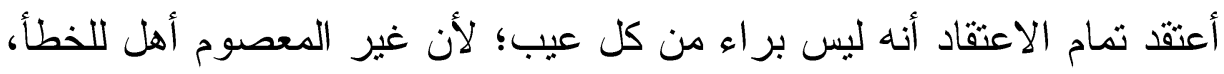

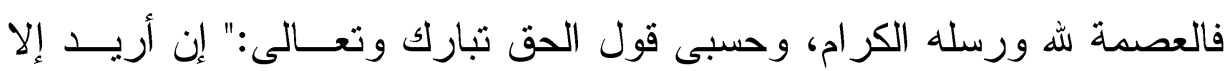
الإصلاح ما استطعت وماتوفيقى إلا بالله عليه نوكلت و إليه أنبب "(1).

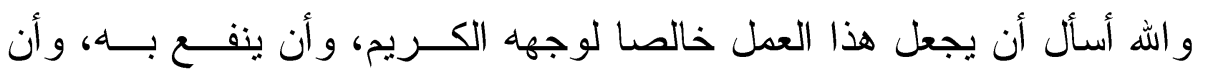

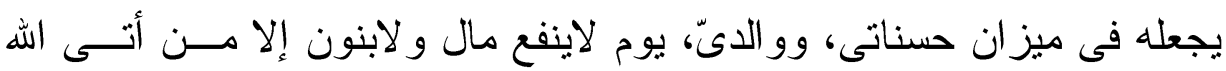


بقلب سليم، إنه ولى ذلك والقادر عليه، وهو نعم المولى ونعم النصير، وصلى اللهم على سيدنا محمد و على آله وصحبه وسلم. المبحث الأول

\section{الطهارة في الثريعة الإسلامية}

للطهارة أهمية كبيرة في الإسلام، سواء أكانت حقيقية كطهارة الثوب و البدن الإسنه

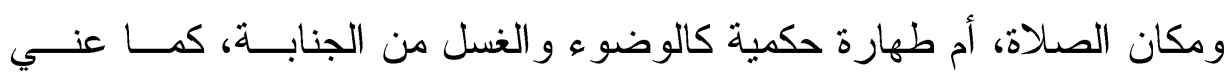

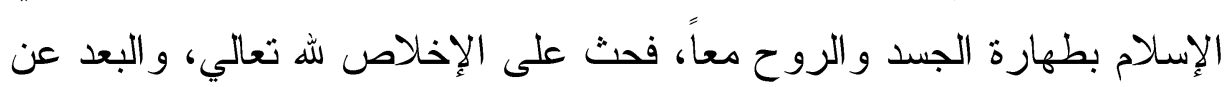

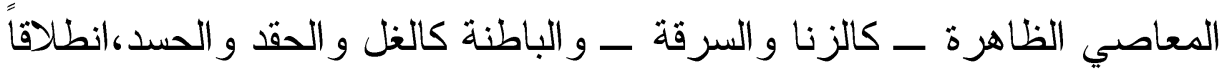

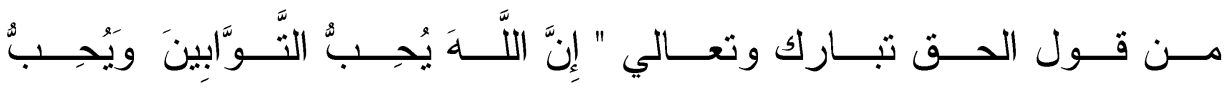

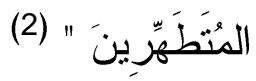
وتمتد هذه العناية لتشمل البيئة المحيطة بالإنسان، والتي هي عنوان حضارته

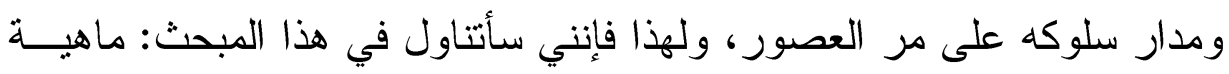

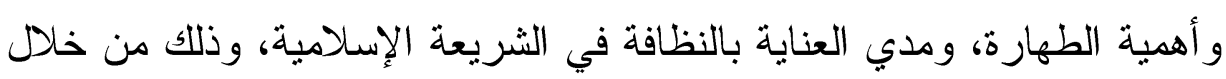
مطلبين كالتالي: المطلب الأول: ماهية وأهمية الطهارة في الشريعة الإسلامية. المطلب الثاني: عناية الشريعة الإسلامية بالنظافة. 


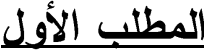

ماهية وأهمية الطهارة في الثريعة الإسلامية

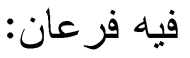

الفرع الأول: ماهية الطهارة.

الفرع الثاني: أهمية الطهارة في الثريعة الإسلامية.

\section{الفرع الأول}

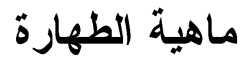

أولا: في اللغة:

الطهارة لغة: النظافة من الأوساخ والأقذار الحسية و المعنوية (3)، يقال: طهر

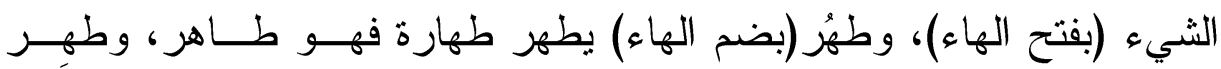
وطهير ، والجمع أطهار. (4)

\section{والاسم: الطُهر (بالضم) نقيض النجاسة. (5) ولهُ}

و الطهور (بفتح الطاء) اسم لما يتطهر به من ماء وغيره، ومنه قوله تعـالي

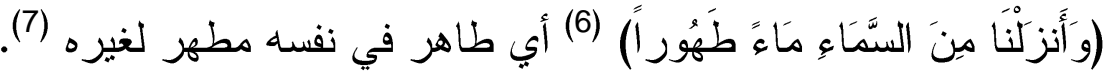
أما الطهور (بضم الطاء) فهو التطهر، وهو اسم للفعل، كالوضوء و الغسل(8)، وقال الليث: و التوبة التي تكون بإقامة الحد نحو الرجم وغيره، طهور للــذنب

تطهره تطهيرً (9).

$$
\begin{aligned}
& \text { (") مادة (طهر) لسان العرب 504/4، المصباح المنير ص18/2، تهذيب اللغة 19/6. }
\end{aligned}
$$

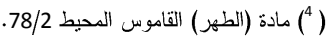

$$
\begin{aligned}
& \text { () (1) لسان العرب، المصدر السابق. }
\end{aligned}
$$

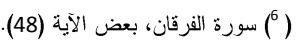

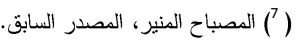

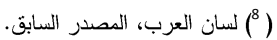

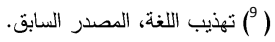




\section{ثانيا: في اصطلاح الفقهاء:}

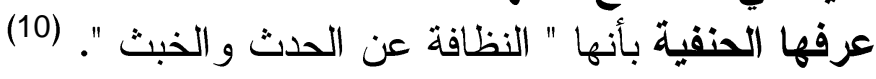

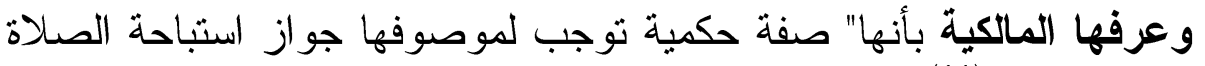
به أو فيه أوله" (11).

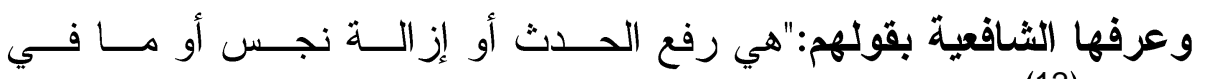

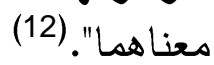
وعرفها الحنابلة بأنها:" رفع ما يمنع الصلاة من حدث أو نجاسة بالهـاء أو رفع حكمه بالتز اب". (13 وفهابلة بأنها: ويلاحظ فيما سبق من تعريفات الفقهاء للطهارة، أنها ركزت على النظافة من الن النه

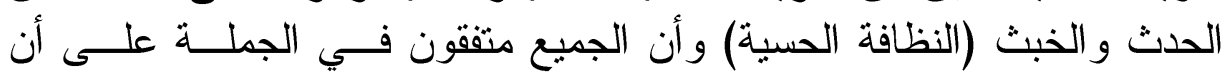

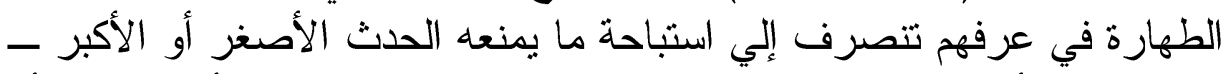

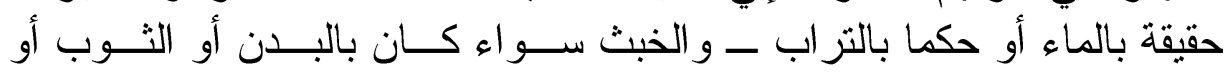

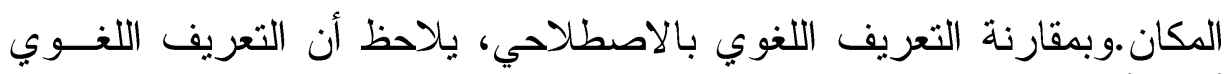

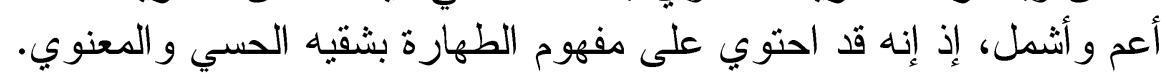

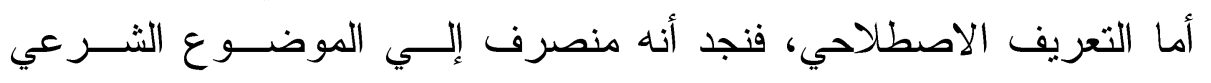
(الطهارة الحسية) وذلك أنه إذا أطلق لفظ الطهارة في لفظ الثـــار ع أو كــلام

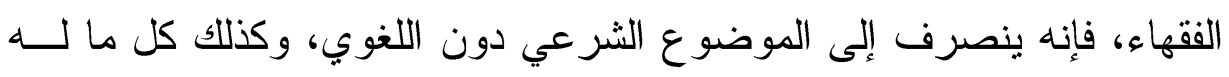

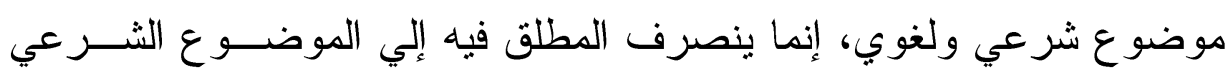

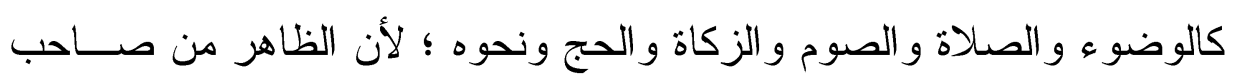

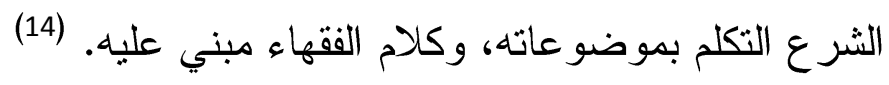

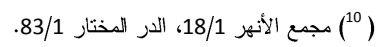

(11) هذا التعريف لابن عرفة الورغي في الحدود مع شرح الرصاع 17/1، الثرح الكبير للاردير 30/1، 31 31، مواهب الجليل 61/1.

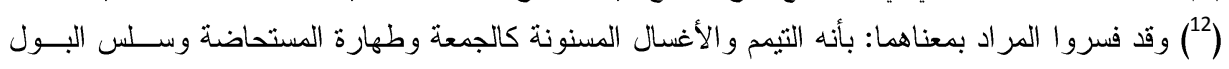


و هذا الإطلاق لا يطرد في لغة القرآن الكريم و السنة النبوية المطهرة، و إنمــــا

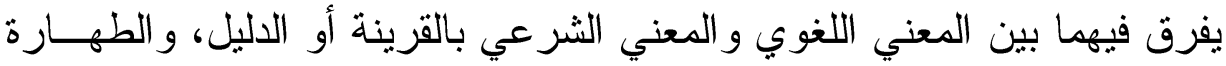

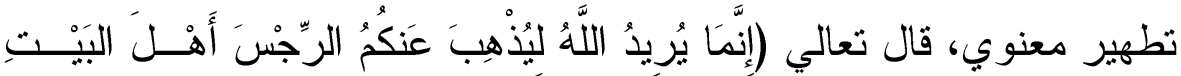

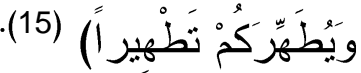

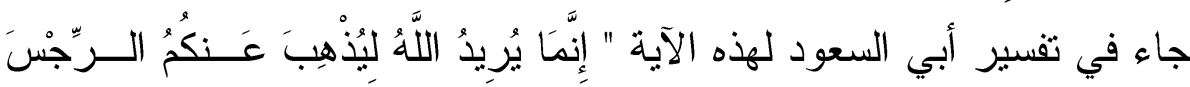

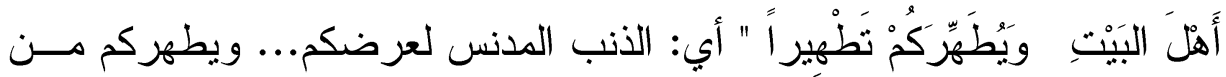
الأوزار و المعاصي تطهير أ..... " (16).

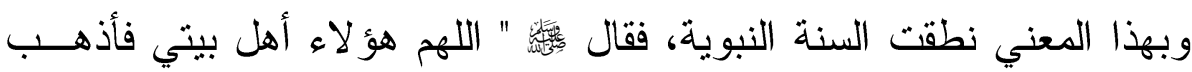
عنهم الرجس وطهر هم تطهير ا" (17).

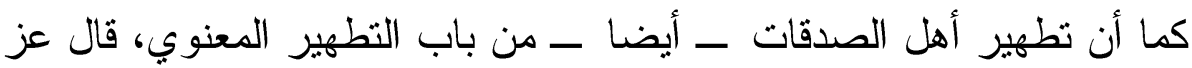

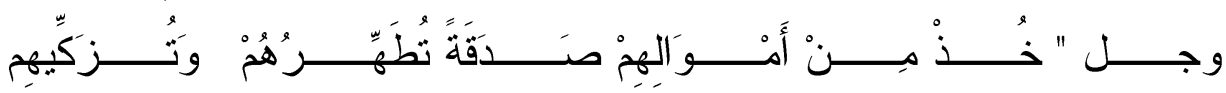
بهـا " (18) جاء في تفسير الطبري:" إيتاء الزكاة تطهير للنفوس و الأبدان مــن أدنــاس الآثام". (19)

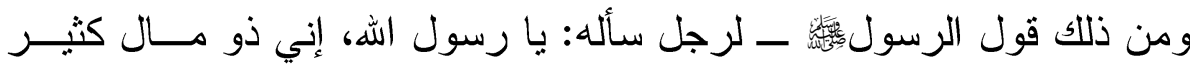

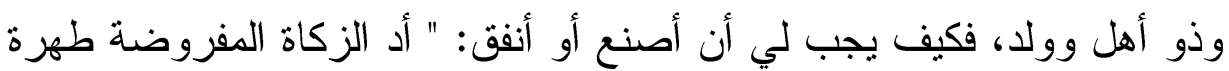
تطهرك". (20) أي: تطهر قلبك وبدنك من الذنوب ولن والآثام.

(103) سورة التوبة، بعض الآية (103)

(17)

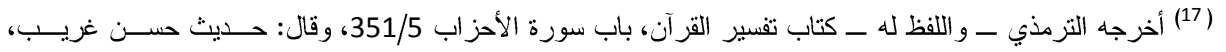

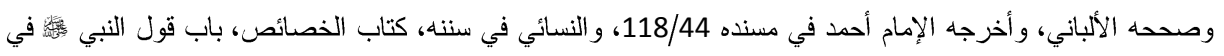

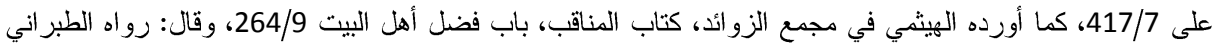

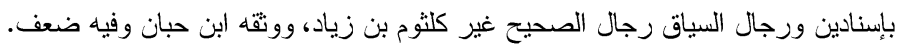

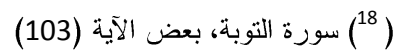

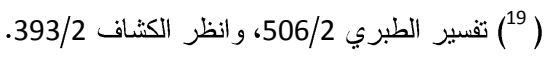
(230) أخرجه الحاكم في المستدرك، كتاب الزكاة 392/2، وقال: حديث صحيح على شرط مسلم. 
أما إذا لحق لفظ التطهير بالماء، فالمر اد به الطهارة الحسية، ومنه قوله جـلـل

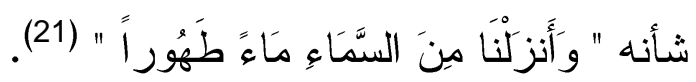

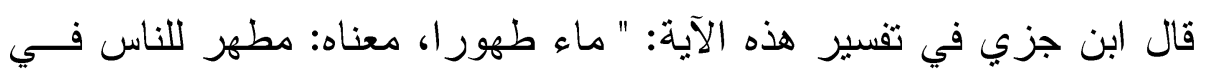

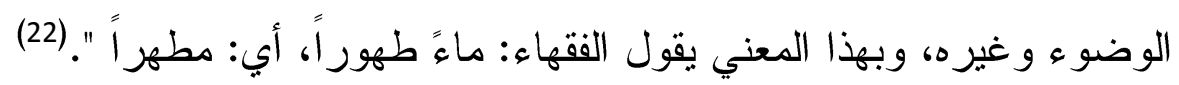

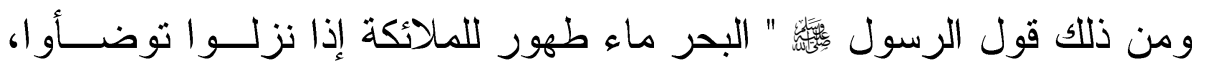

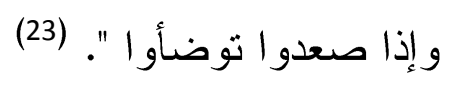
وليس معني هذا أن الفقهاء رضوان الله عليهم قد أغفلوا الحديث بالكلية عـنـ

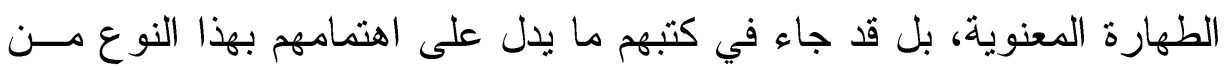

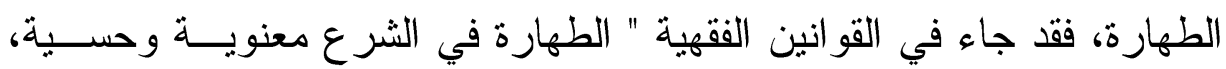
فالمعنوية طهارة الجوارح و القلب من دنس الذنوب. و الحسية: هي الفقهية التي لهي نز اد للصلاة ". (24) خلاصة القول: أن الطهارة إما طهارة حسية، وتعني نظافة البــدن والثـوب و المكان (وهي الطهارة من الخبث) ونظافة الثخص نفسه أو المصلي بأفعــال

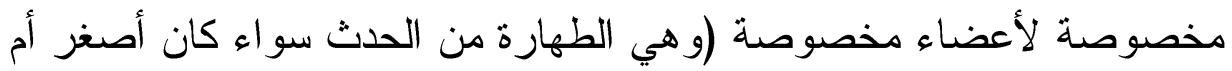

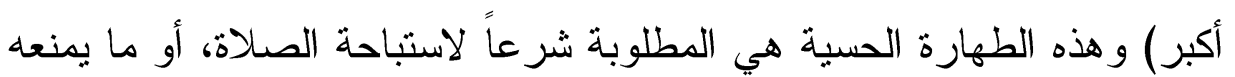

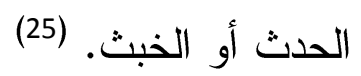

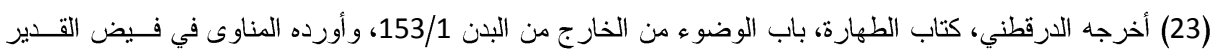


و إما طهارة معنوية، وتعني تزكية النفوس بخلو ها من المعاصــي و الــنوب الظاهرة ــ كالزنا و السرقة وشرب الخمر ــ و الباطنة كالعجب و الكبر و الرياء

و النفاق. (26)

و هذا فيما يتعلق بالجانب الفقهي بالنسبة للطهارة.

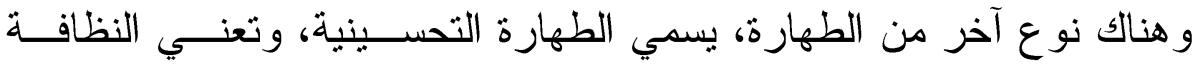

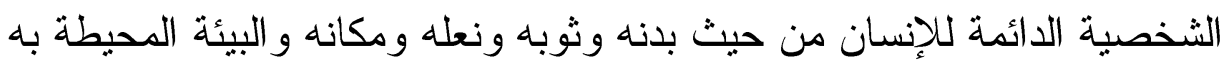

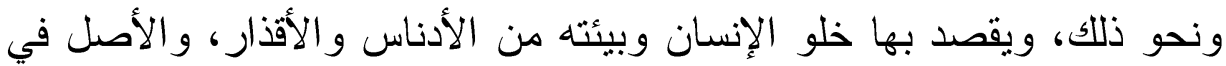

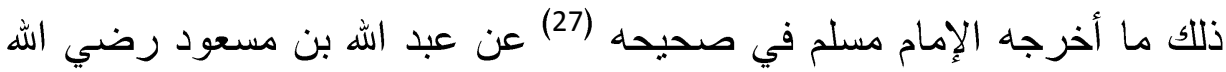

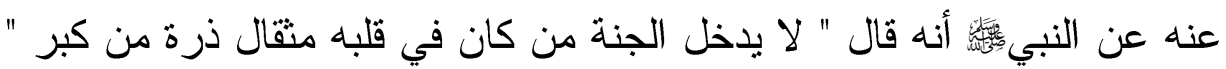
فقال رجل يا رسول الله، إن الرجل يحب أن يكون ثوبه حسنا ونعله حسنا، فقال

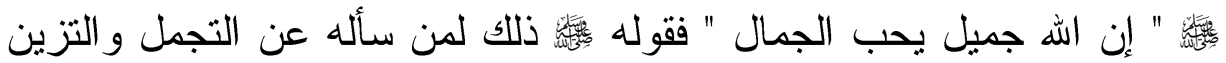
بنظافة الثوب و النعل ونحو ذلك من النظافة الثخصية أو الطهــارة التحســـينية

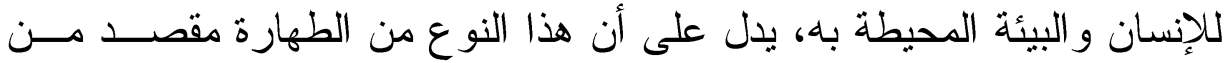
مقاصد الشريعة الإسلامية.

\section{الفرع الثاني}

\section{أهمية الطهارة في الثريعة الإسلامية}

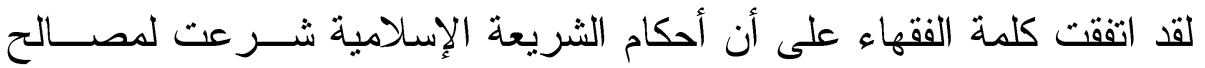

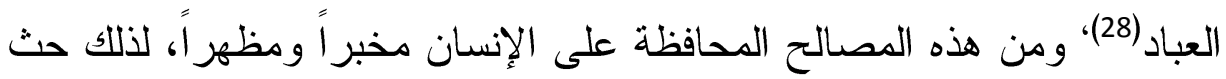

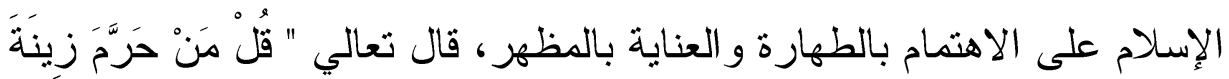

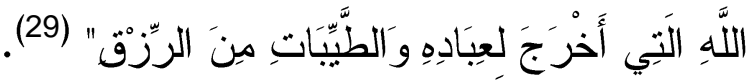


فالمر اد بالزينة في الآية، جميع أنواع التزيين من الملبس الحسـن وتتظيــف فئف البدن من جميع الوجوه، ونحو ذلك (30).

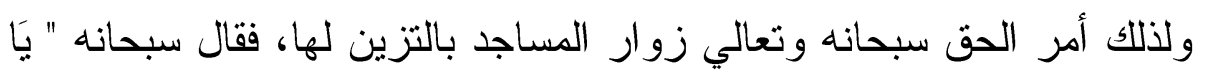

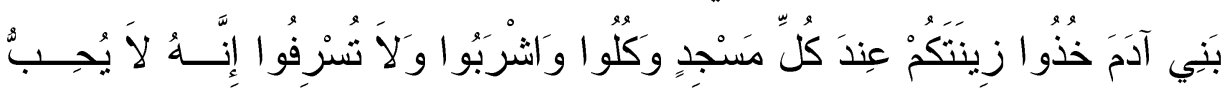

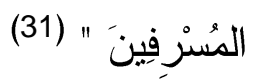
فقبل أن يحثهم المولي عز وجل على الأكل من طيب الطعام والثراب،ليقوي

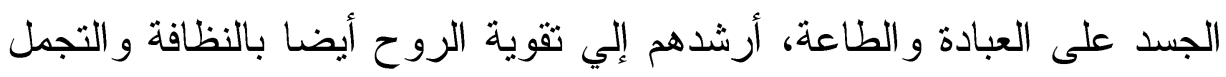

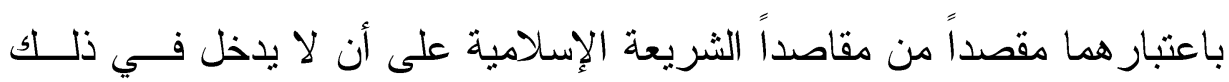

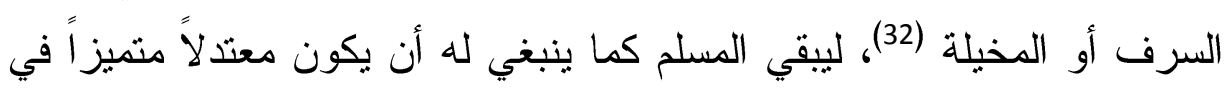
نظافته وطهره، ومن ثم فالطهارة هي أساس الزينة.

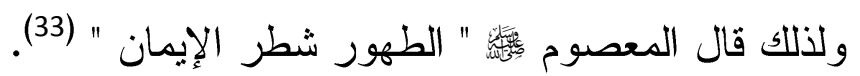

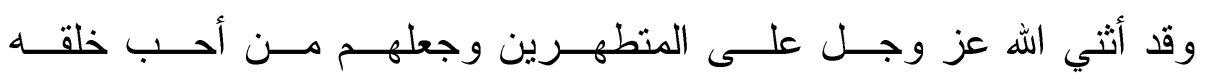

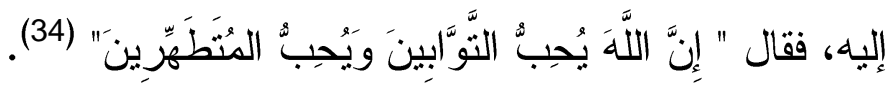

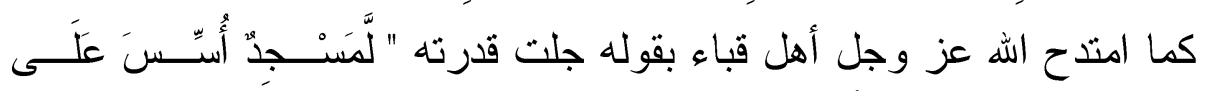

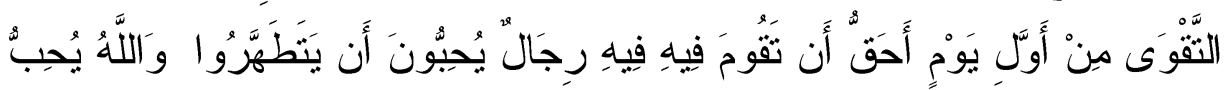

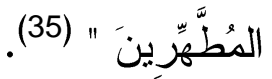


فكان مدحهم لأنهم أسسوا مسجداً على التقوى من الهه ورضوان، بالإضــافة إلي محبتهم للطهارة و النظافة (36).

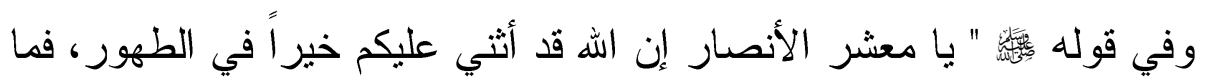
طهوركم هذا ؟ قالو ا يا رسول الله: نتوضأ للصلاة ونغتسل من الهن الجنابة، فقــال رسول الله

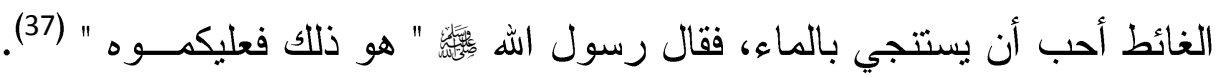
إثارة إلي الطهارة و النظافة المتمثلة في الوضوء باءه

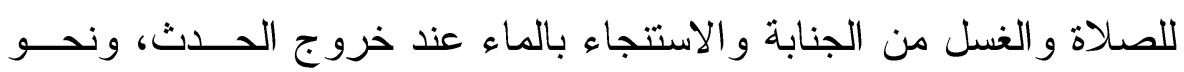
ذللك، تكسب ثناء الله ومدحه، وتورث محبته جل في علاه.

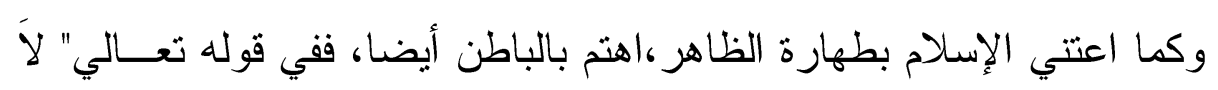

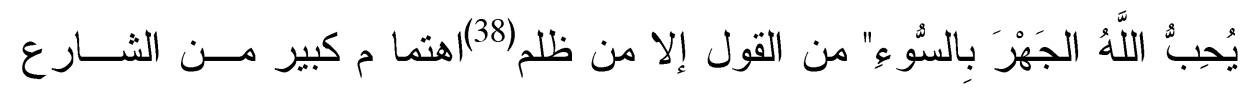

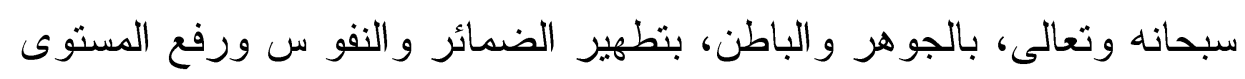

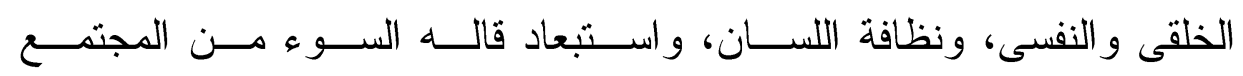

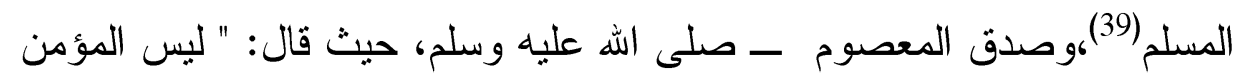
بالطعان و لا اللعان و لا الفاحش و لا البذئ "(40).

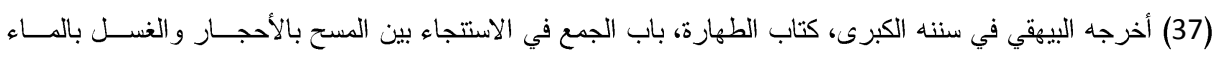

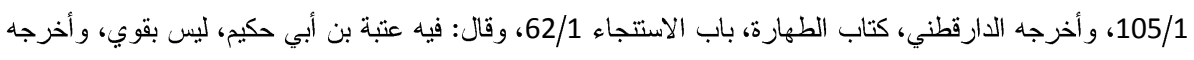

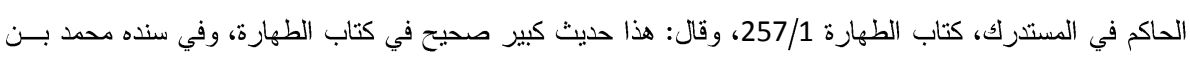

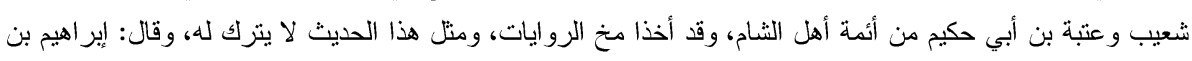

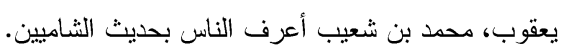

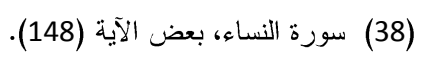

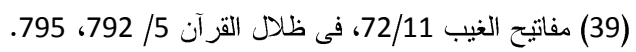

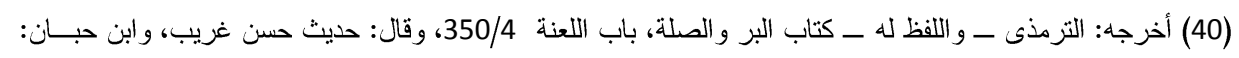

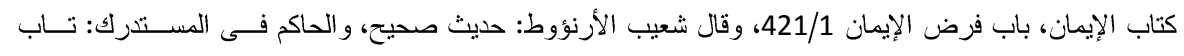

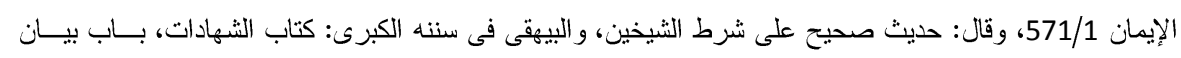
مكارم الأخلاق ومعاليها 193/10. 
و المر اد بالطعان (بالتشديد) الوقاع فى أعر اض الناس بنحـــــ ذم أو غيبــة،

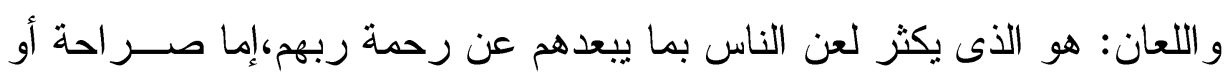

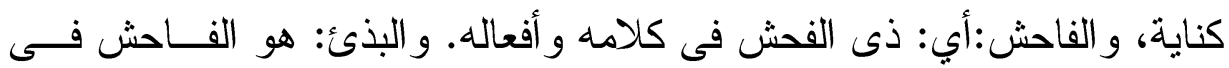
منطقة، وان كان الكلام صدقا(41). ذلك أن الإسلام يريد أن يكون المسلم متفوقا في سلوكياته وأخلاقه الفرديــة

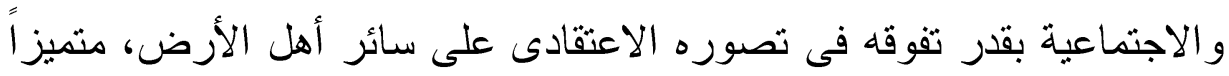

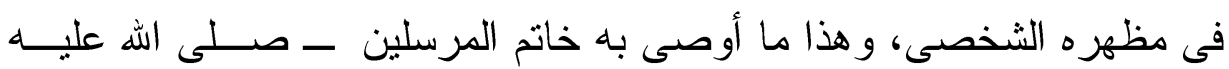

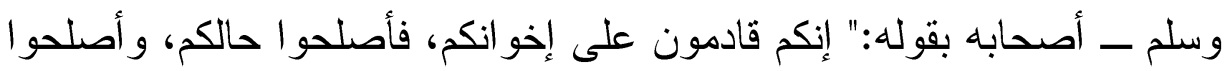

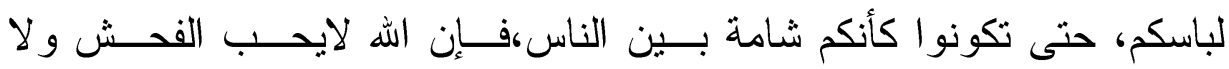
التفحش" (42). فالإسلام يريد من المسلم أن يكون فى أصلح زى و أحسن هيئة و أعظم سلوك

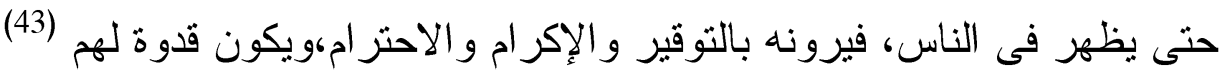

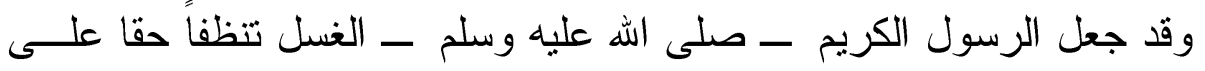

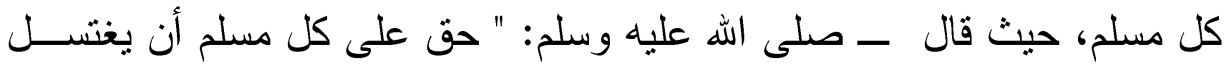
فى كل سبعة أيام، يوماً يغسل فيه رأسه وجسده " (44).

642/2 سبل السلام 198/4، فيض القير (41)

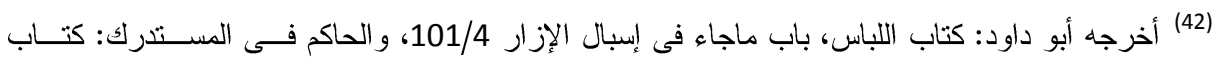

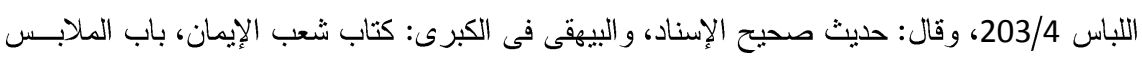

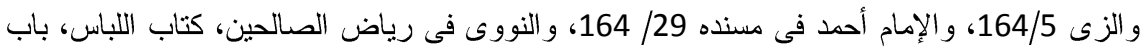

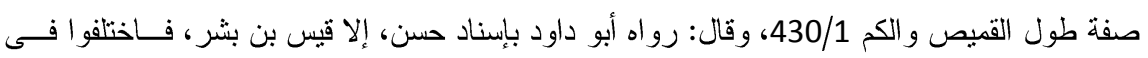


فيرشد الحديث إلى الغسل المستحب، كما قال جمهور الفقهاء، ويتمثل ذلـــك

فى مو الاة نظافة البدن كله مرة كل أسبوع على الأقل (45).

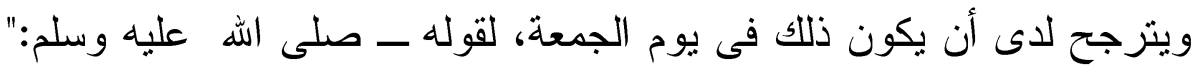

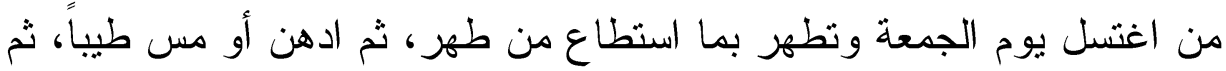
راح فلم يفرق بين اثثين، فصلى ماكتب له، ثم إذا خرج الإمام أنصت، غفر له له

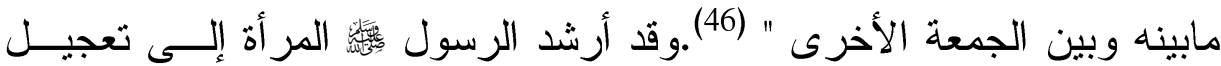

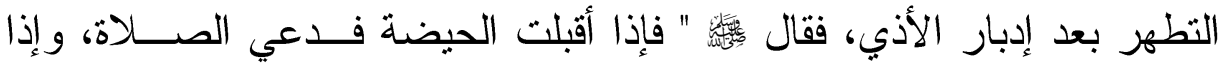

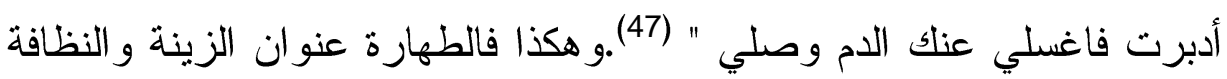

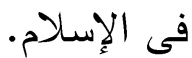




\section{(المطاب الثانى}

عناية الشريعة الإسلامية بالنظافة

للنظافة أهمية كبرى فى الإسلام،ولذلك أمر الشارع بالاهتمام بها و المحافظة

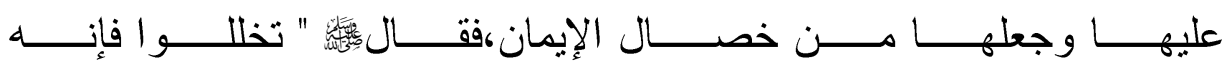
نظافة، و النظافة تذعو إلى الإيمان،و الإيمان مع صاحبه فى الجنة (48)". فالتخلل بالماء في الوضوء و غيره بالمضمضـة و الاستنشاق و غسـلـل البــدين وتخليل الأصابع ونحو ذلك، إنما هو نظافة،و النظافة مرنبطة بالإيمان، و الإيمان

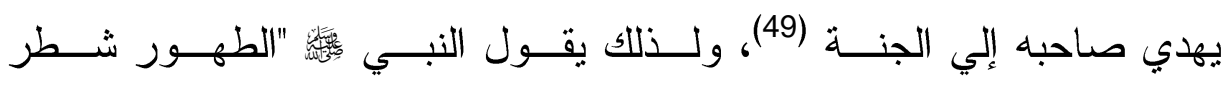

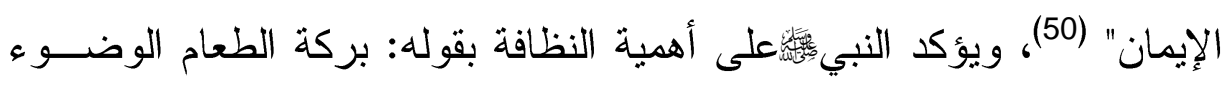

قبله و الوضو ء بعده" (51).

(48 أخرجه الطبر اني في المعجم الأوسط 215/7، وأورده المتقى الهندى فى كنز العمال، كتــاب الطهـارة،

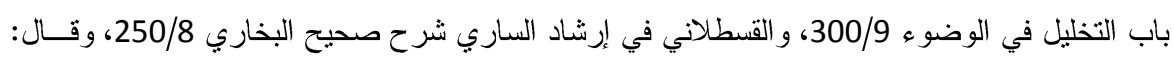

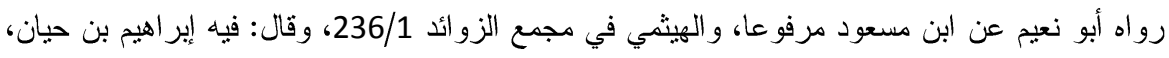

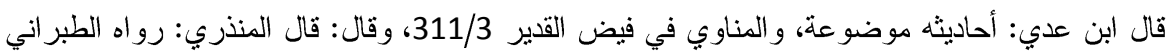

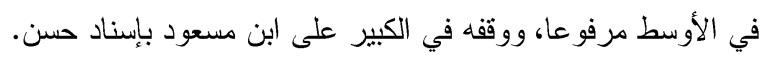

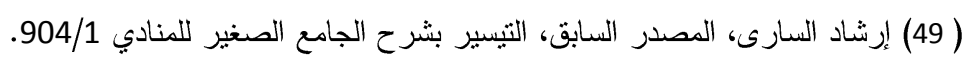

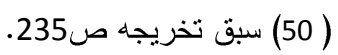

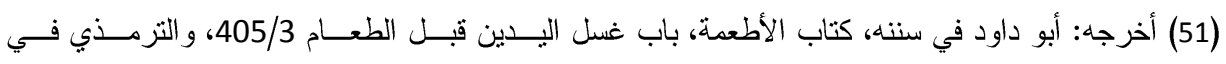

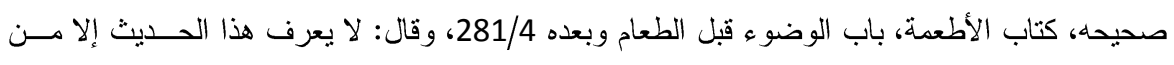

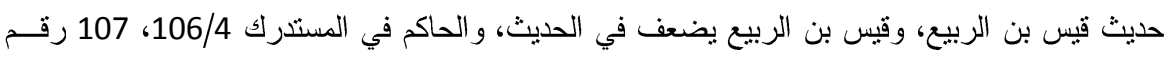

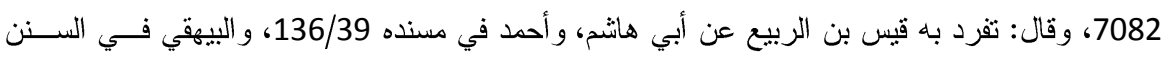

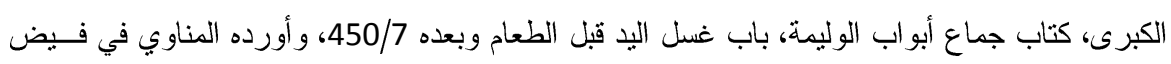

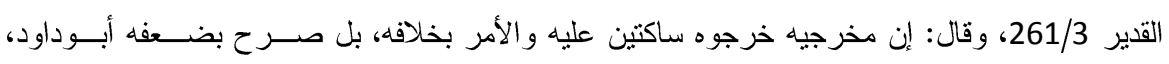

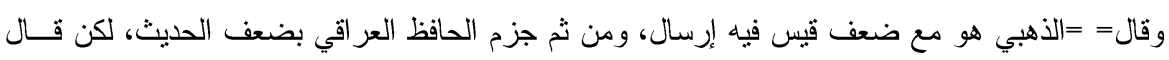

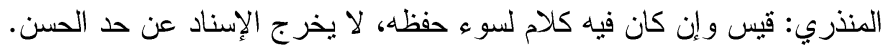


و هذا تأكيد لأهمية النظافة في الإسلام، فالوضوء قبل الطعام لأجـل غسـلـ

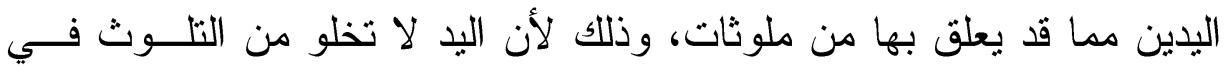

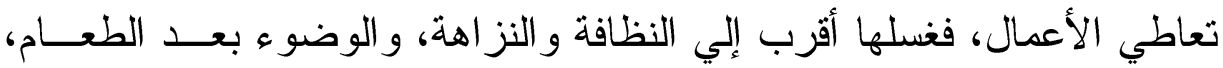
غسل اليدين من الدسومات. (52)

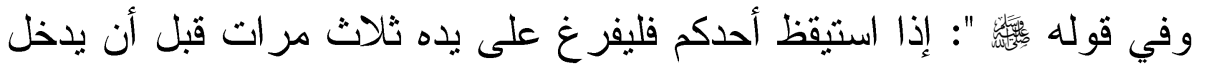

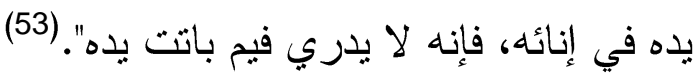
شدد : شيءلأن مظنة تلوثها حال النوم أكثر من اليقظة، حيث لا بعلم صاحبها أيسـن باتت.

$$
\text { و هكذا فالنظافة عنوان الإيمان. }
$$

ولذلك كانت دائما محل عناية واهتمام من الشارع الإسلامي، فقد اعتني فوق ما تقدم بنظافة الفم وشدد على ذلك، فقال : أو قال فليعتزل مسجدنا وليقعد في بيته"(54).

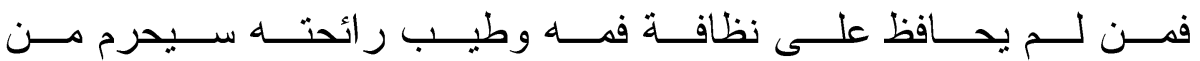
الجماعة، لئلا يؤذي مجاوريه في العبادة. (55)

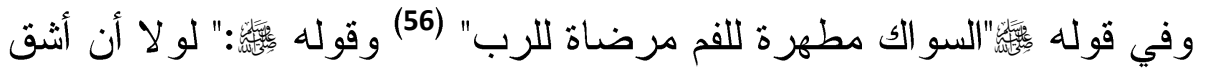
على أمتي لأمرتهم بالسو اك عند كل صلاة" (57).

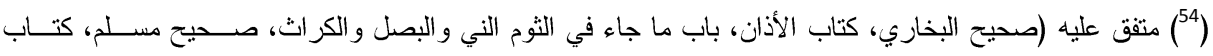

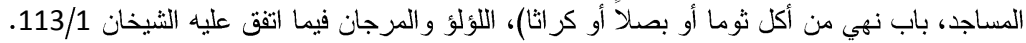

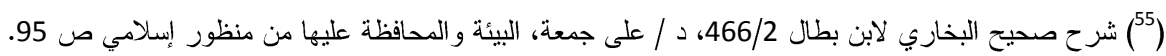

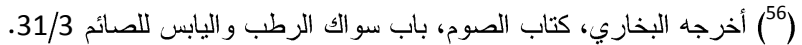

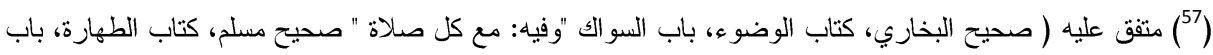
السو الك ) اللؤلؤ والمزجان (59/1. 


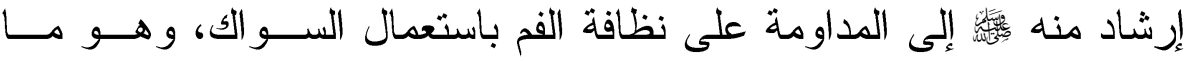

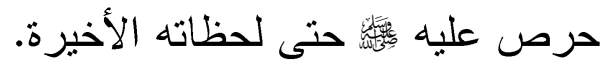
وقد أمر مَ

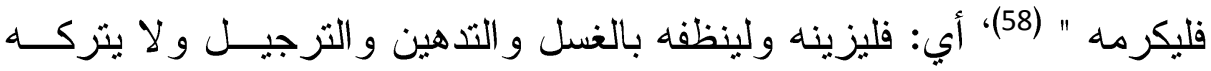

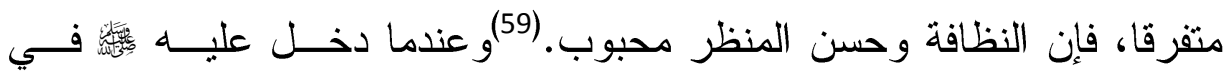

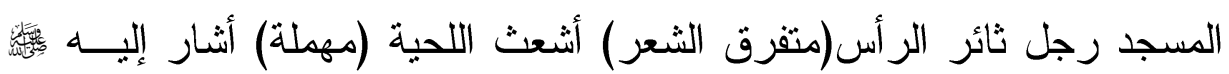

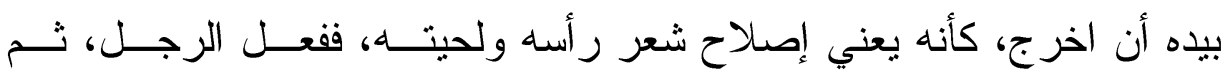

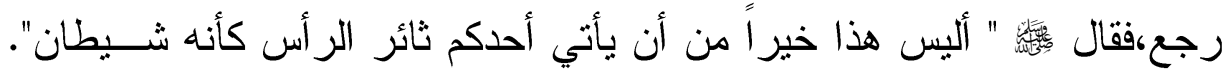

ذللك أن إهمال الشعر وترك النظافة والاغتسال، سبيل لتجمع الوسخ والآفات مما ينفر الناس. و إذا كان الإسلام قد اعتتى بنظافة البدن، فإنه قد اعتنى بنظافة الملبس أيضا،

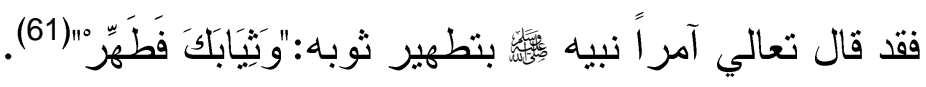
وفي كل من الثياب و الطهر وجوه:

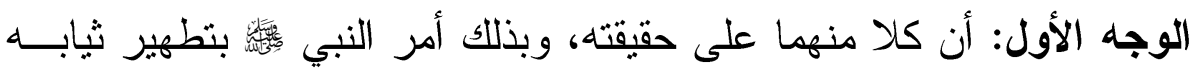
من الأنجاس و الأقذار . (62)

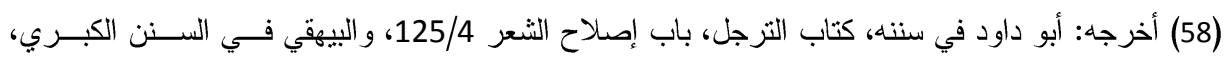

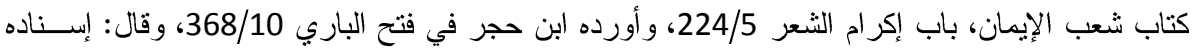

$$
\begin{aligned}
& \text { (147/11. } \\
& \text { ( (20) أخرجه مالك في الموطأ رواية يحيي بن يحي،، كتاب الثعر ، باب إصلاح الثعر 949/2. }
\end{aligned}
$$

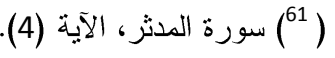

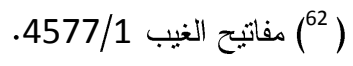


قال الإمام الثافعي: " فالمقصود بالآية على هذا الإعلام بأن الصلاة لا تجوز

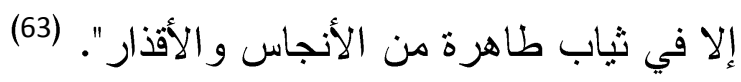

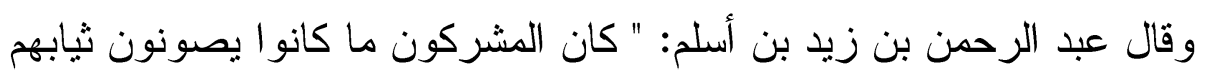

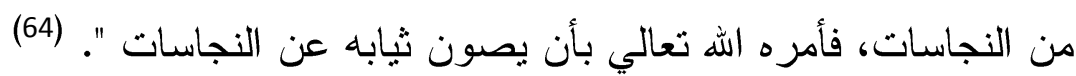

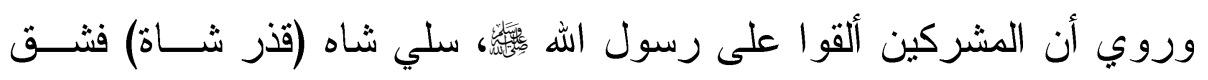

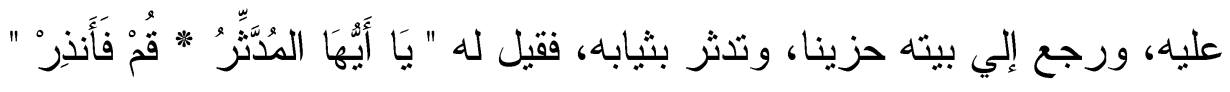

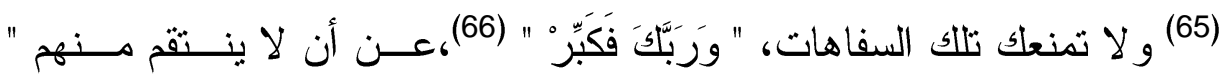

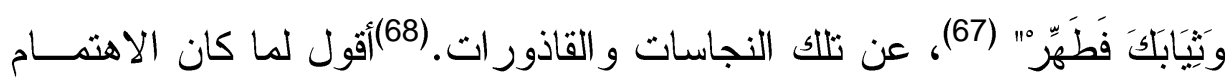
بإز الة القذر والنجاسة من الثياب في بدء الإنذار بالرسالة، دل على أن الإسلام

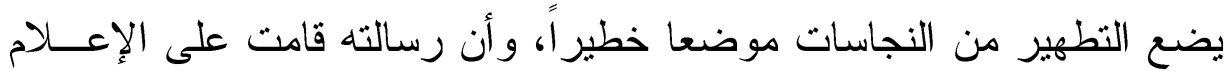
الصحي، ومنه أن إز الة القذر تكليف على سبيل الوجوب، وليس علــى ســبيل

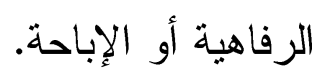

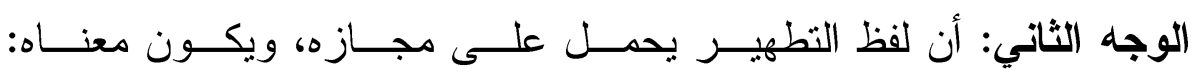

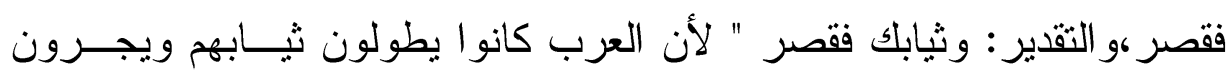

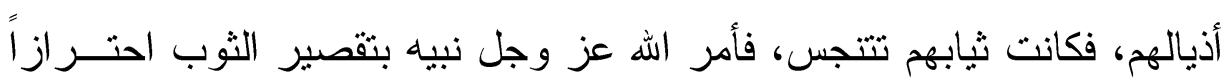
عن النجاسة. 
وقيل: يحتمل أن المراد بتطهير الثياب، أي: اكتسابها من حسـلال و المعنـي:

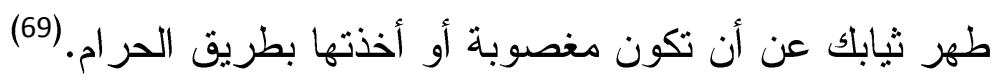

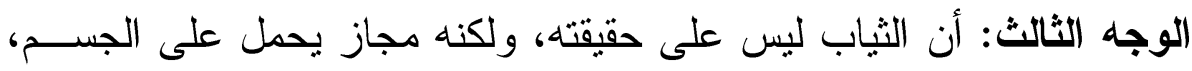

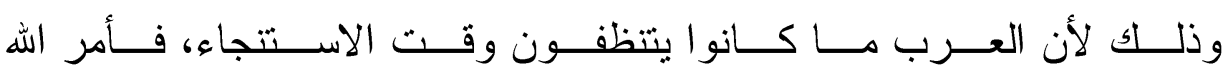

نبيه

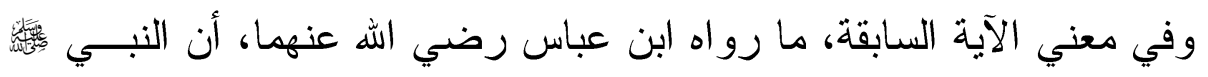

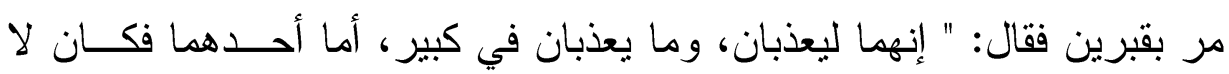

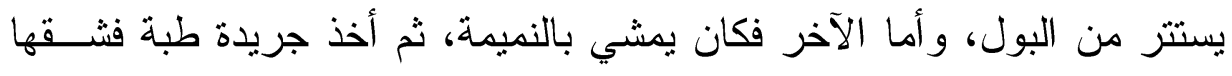

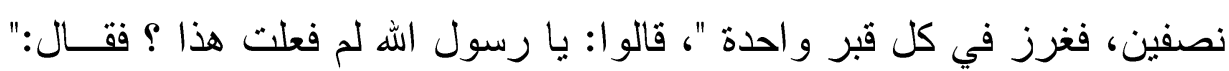
لعله أن يخفف عنهما ما لم ييبسا " (71). فقد دل هذا الحديث على الأمور الآتية: 1.عذاب القبر ، فقد صرح الحديث بإثبات عذاب القبر وهو ما عليه مذهب أهل الهون السنة، لاشتهار الأخبار بذلك.

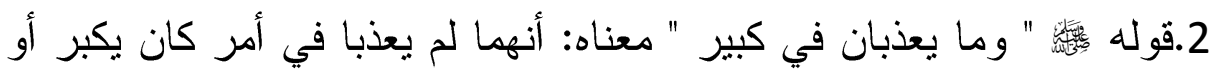

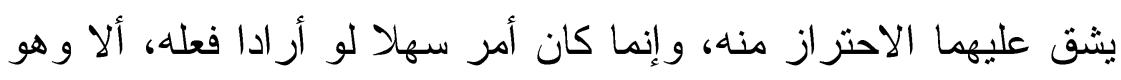

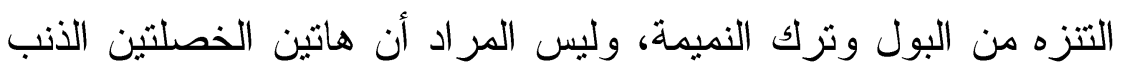
فيهما سهل لين في أمر الدين. (72)

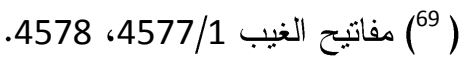

$$
\begin{aligned}
& \text { (10) }
\end{aligned}
$$

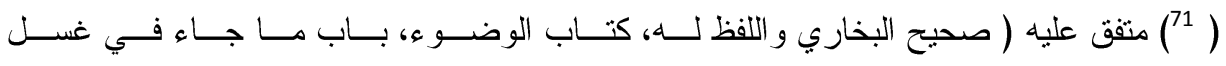

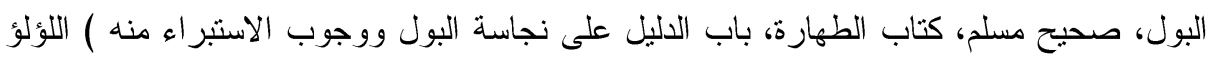
و المرجان 65/1. 19/1 (2) (2) معالم السنن للخطابي (12) 
3.قوله

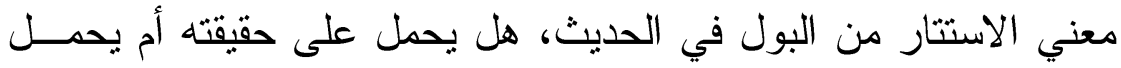
على المجاز ؟ للعلماء في ذلك وجهان: الوجه الأول: أن الاستتار يحمل على حقيقته، وهو الاستتار عن الأعين، أي: التخفي عند التبول، و على هذا الوجه يكون العذاب على كشف العولى العورة. (73)

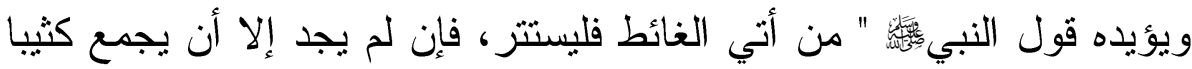

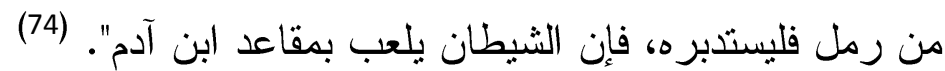

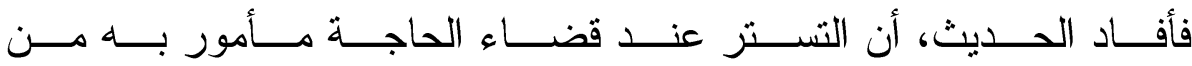

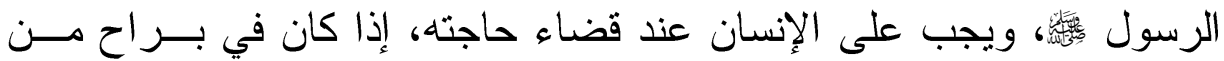

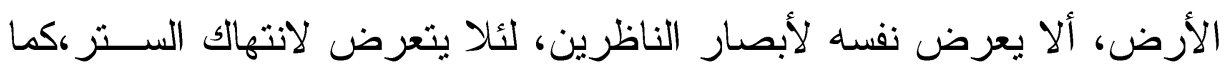
عليه أن يحتاط ويستتر خلف كثيب من رمل أو مكان مرتفع من الأرض، لئلا

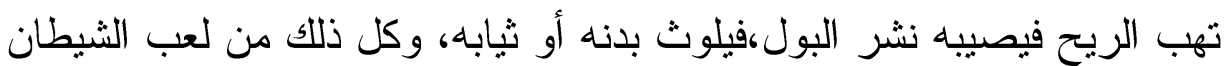

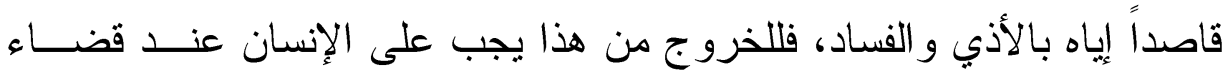
الحاجة، التستر والتخلي عن أعين الناس. (75) الوجه الثاني: أن الاستتار يحمل على المجاز ، ويكون المراد بالاستتار التنزه عن البول و التوقي منه، وعلى هذا يكون العذاب على من لم يتوق عن البــول ولم يتطهر منه ولم يتحرز عن المفسدة التي تتعلق به كانتفاض الطهارة (76).

$$
\text { (أحكام الإحكام شرح عمدة الأحكام لابن دقيق العيد 47/1) }
$$

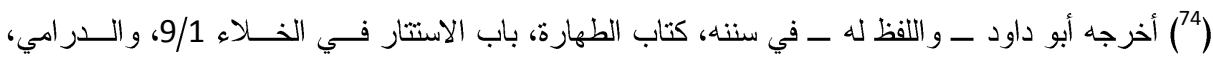

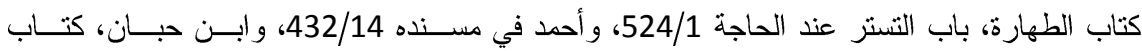
الطهارة، باب الاستطابة 257/4، والييهقي في الكبرى، كتاب الطهارة، باب الاستتار عند قضاء الحاجة

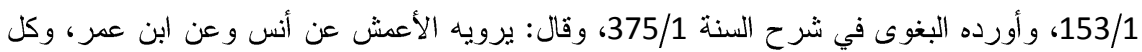


وقد رجح ابن دقيق العيد هذا الوجه (المجاز) لوجهين:

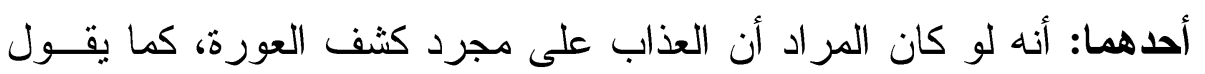

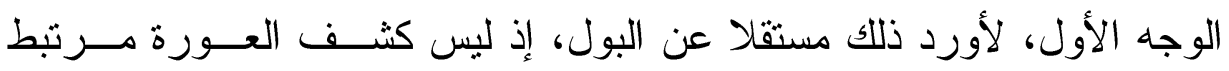

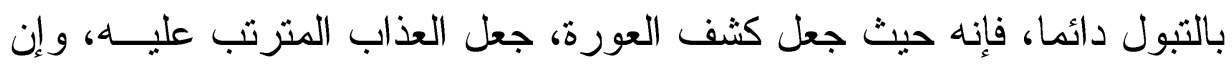
لم يكن ثمة بول. (77)

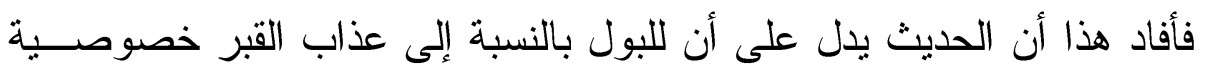

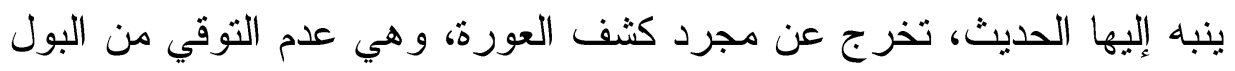
و إهمال الطهارة منه.

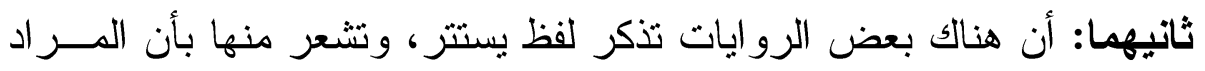

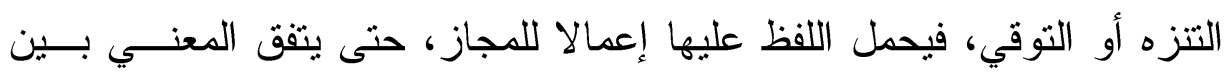

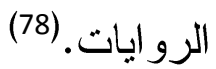

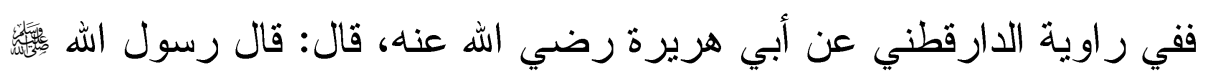

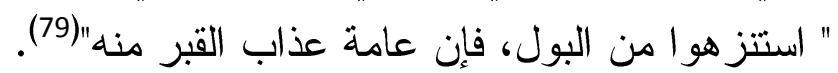

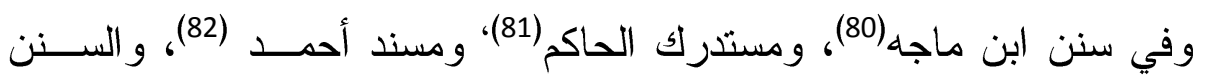
الكبرى للبيهقي (83)، قال

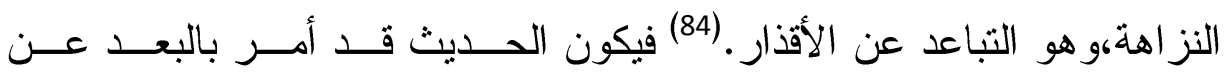

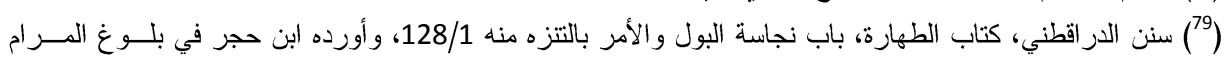
32/1 33، 33، وقال: صحيح الإسناد.

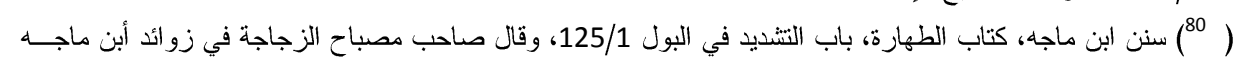

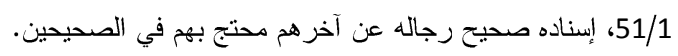

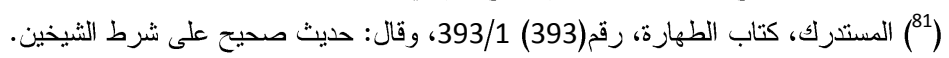
(25/15، رقم 9095 (كسند (23) السنن الكبري، كتاب الطهارة، باب نجاسة الأبو ال و الأرو اث ( ) مادة (نزه)، المصباح المنير ص 239. 


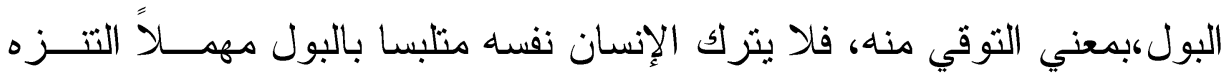

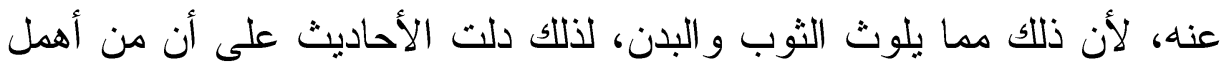

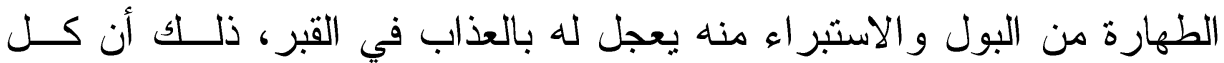

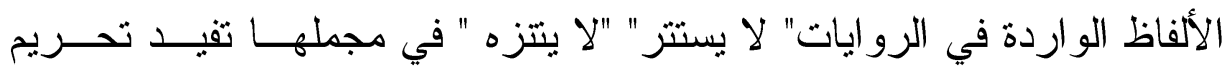

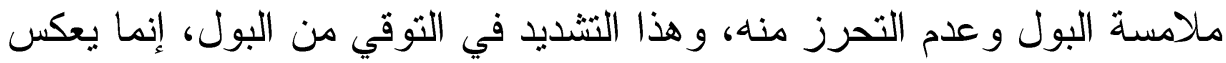

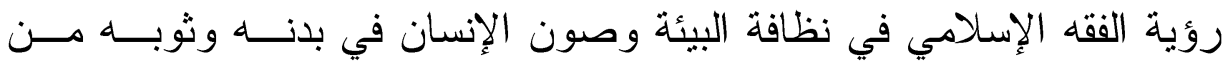

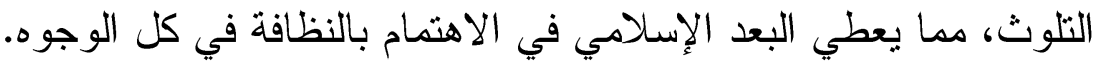

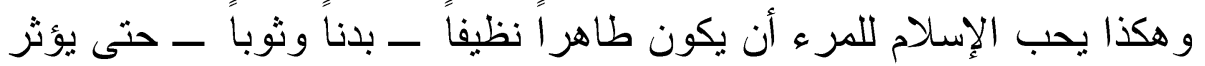
ذللك في سلوكه مع البيئة، فيحاول إصلاحها وتجميلها، وفي ذلك يبدأ الإنســان

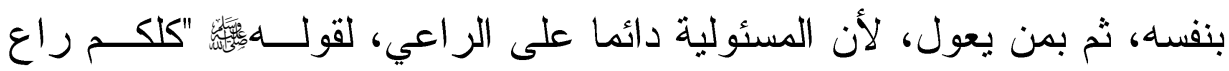

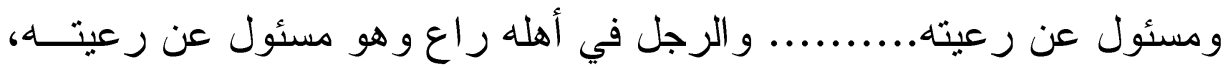
و المر أة في بيت زوجها رواعية وهي مسئولة عن رعيتها........... " (85).

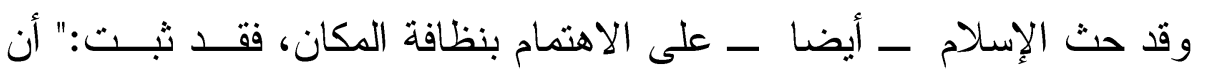
الرسول

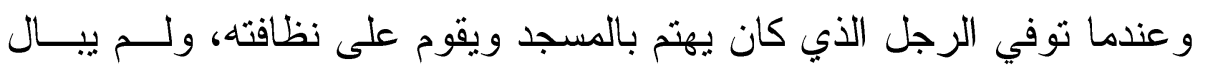

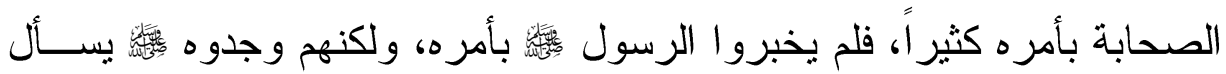

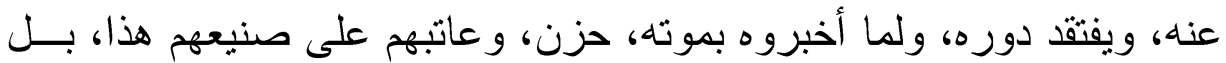

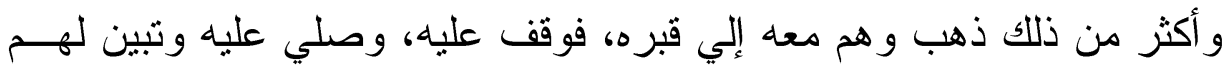
من تعظيم شأنه ومكانته، قيمة الدور الذي يقوم به من دن نظافة المسجد.

(85) متفق عليه ( صحيح البخاري ـ و اللفظ له ـ كتاب العثق، باب التطاول على الرقيق، صــيح

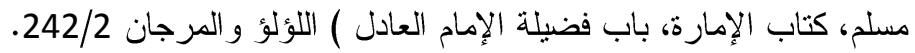

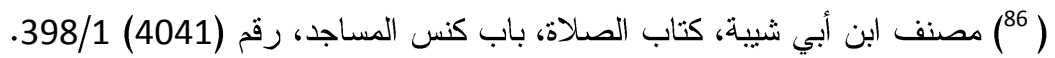

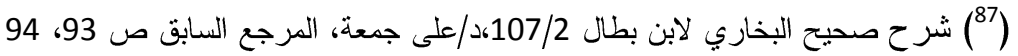
doi: 10.12816/0004230 
مما يدل على أهمية نظافة المكان في الإسلام، فعن أبي هريـرة رضــي الله

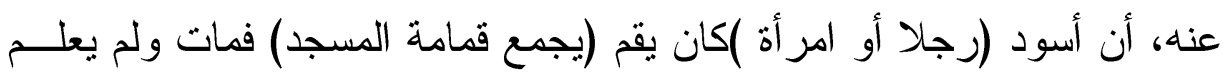

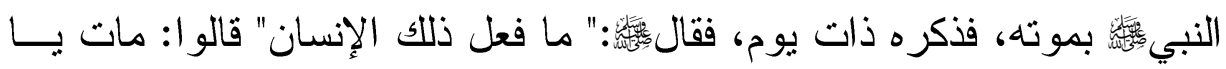

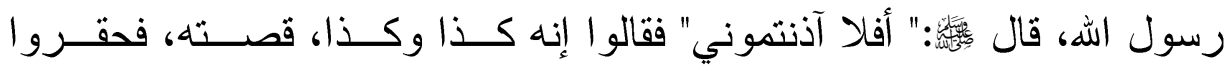
شأنه،قال بك ولا يقتصر الأمر في الإسلام على مجـرد الاهتمــام بالنظافــة الشخصــية و المكانية للإنسان فحسب، و إنما يمتذ إلـى العنايـــة بنظافـــة البيئـة بصــفة عامة،فتحض السنة النبوية على التعامل مع البيئة بصورة نظيفة، وتمنــع مــن إلقاء الفضلات و التبول في الماء أو في طرقات الناس دفعاً للأذي و التلوث

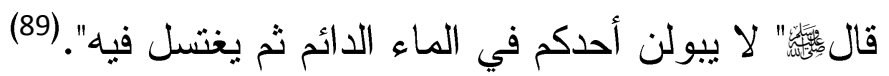
وقال "إس طريق الناس أو في ظلهم" (90). أي:يلقي فضلاته فيها أو يقضي حاجته. (91) فالطريق مسار عام، و أماكن الظل يتواري فيها الناس، اتقاء من الشمس،فمن يفسد على الناس طريقهخ أو أماكن راحتهم، فقد ألحق الضرر بالناس، ولــوث بيئتهم، فاستحق اللعن.

( ) متفق عليه (صحيح مسلم ـ و اللفظ له ــ كتاب الجنائز ، باب الصلاة على القبر ، صحيح البخاري، كتـاب

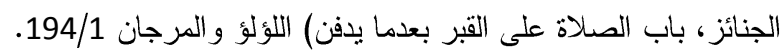

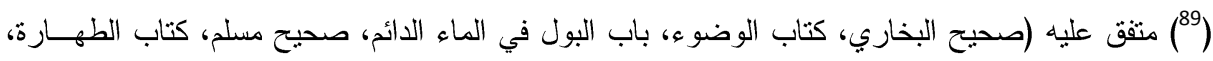

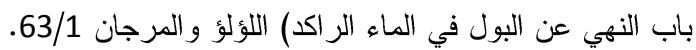

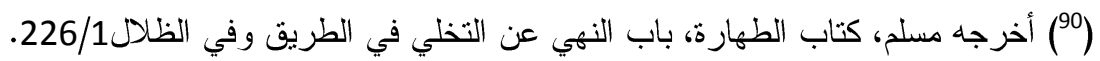
(191 ) شرح النووي على صحيح مسلم 162/3 - سبل السلام 75/1. 


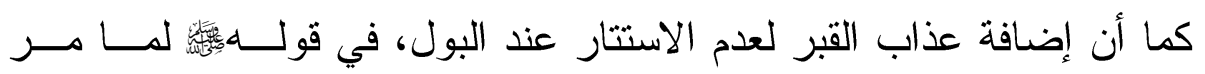

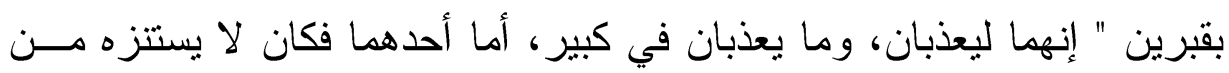

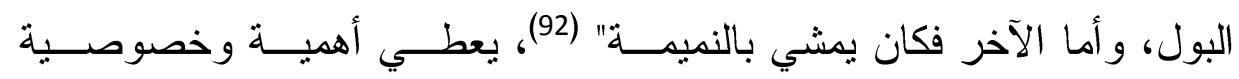

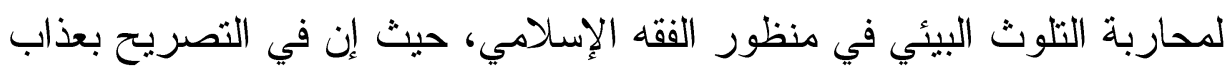

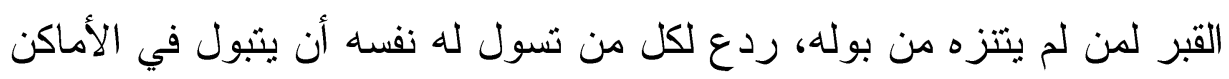

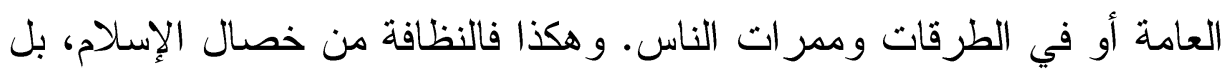

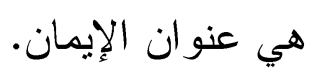

المبحث الثاني

مفهوم الاستحالة وتكييفها (لفقهي

أعرض لذلك من خلال مطلبين كالتالي:

المطلب الأول: مفهوم الاستحالة.

المطلب الثاني: تكييف الاستحالة فقهاً.

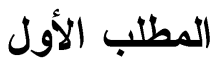

مفهوم الاستحالة

[أ] في اللغة: هي تغير الثيء عن طبعــه ووصــفه وعــدم الإمكــان. (93)

و الاستحالة تكون بمعني التحول؛ لأن التحول هو التنقل من موضع فئع إلي آخــر.

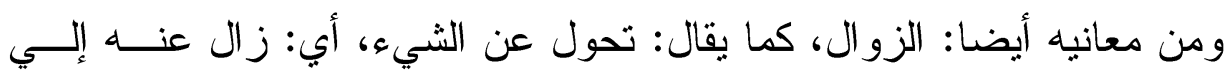
غيره.

وكذلك التغير و التبدل، و التحويل مصدر حول، وهو النقل، فالتحول مطــاوع

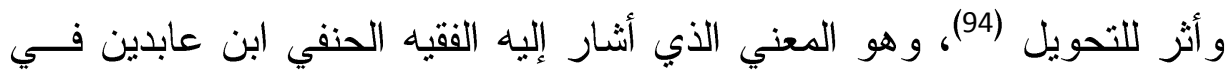

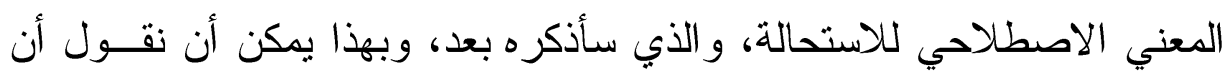

$$
\begin{aligned}
& \text { (22) سبق تخريجه ص243. }
\end{aligned}
$$

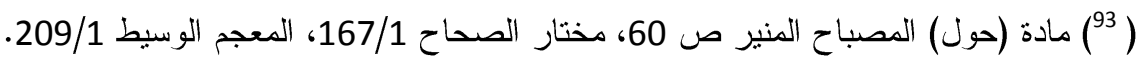

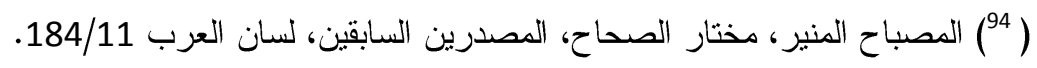

$$
\begin{aligned}
& \text { doi: 10.12816/0004230 }
\end{aligned}
$$


المعني الاصطلاحي قد يرتبط بالمعنى اللغوى، إلا أن المعنى الاصطلاحى يتميز

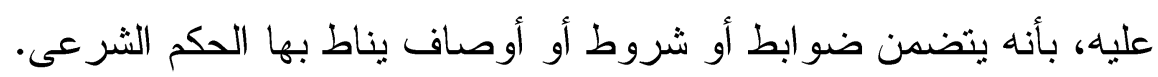

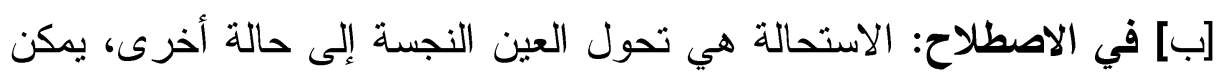

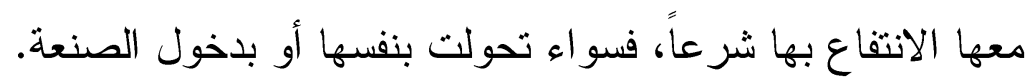

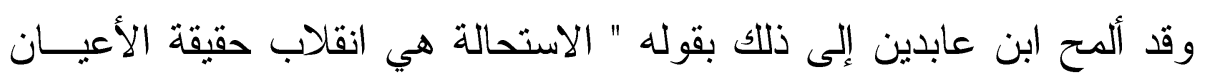
بانتفاء بعض أجز اء مفهومها أو كلها "(95).

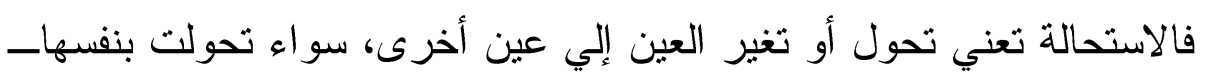

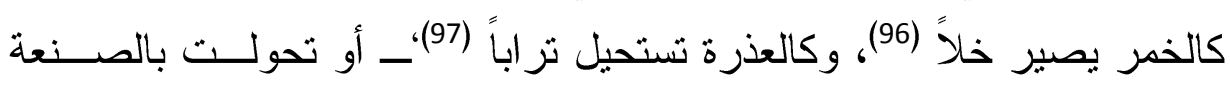
كالجلد بستحيل بدبغه. (98)

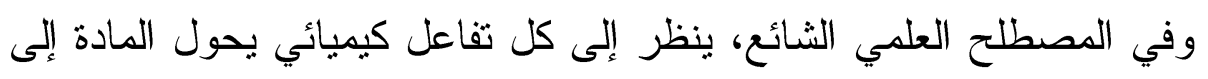

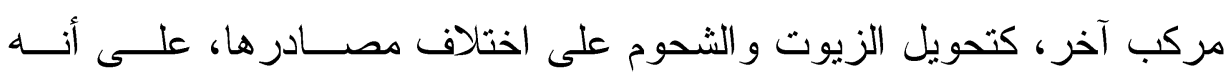

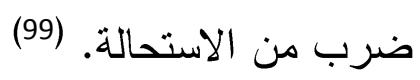
و الغرض من هذا التحول، هو بيان مدي الانتفاع بالعين النجسة بعد استحالتها

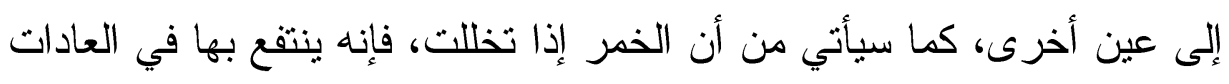

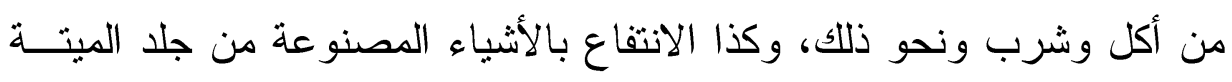

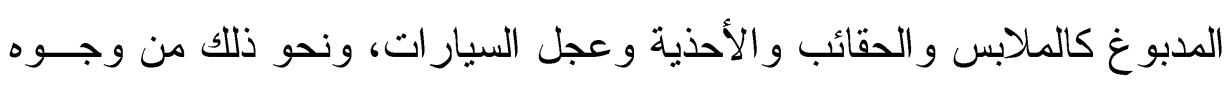

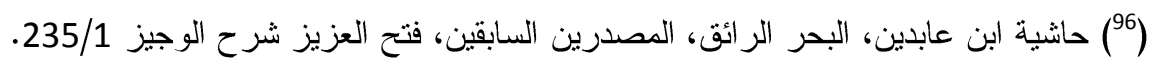

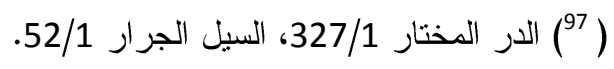

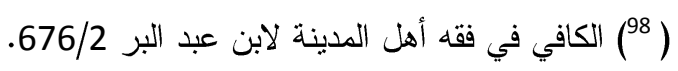

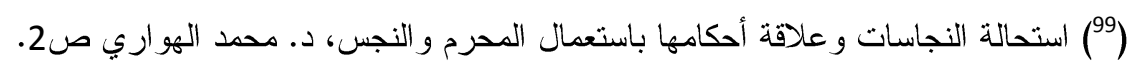


الانتفاع بالأعيان النجسة المستحالة،على النحو الذي سأفصله في محتوي البحث إن شاء الله تعالي.

\section{المطلب الثاني \\ تكييف الاستحالة فقهاً}

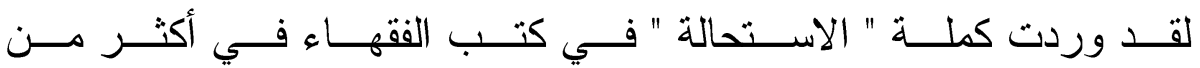

موضع، ورنها:

جاء في الار المختار : "لا يكون نجسا رماد قذر و إلا لزم نجاسة الخبز فـي

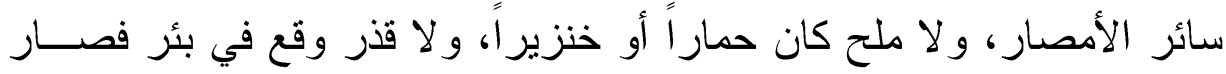

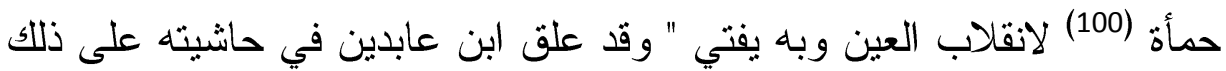

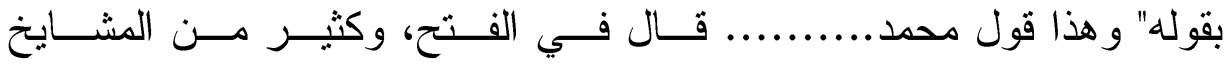

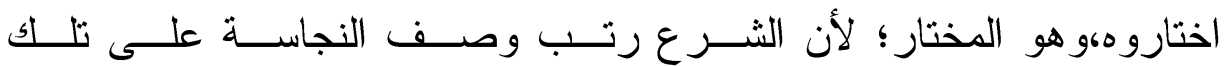

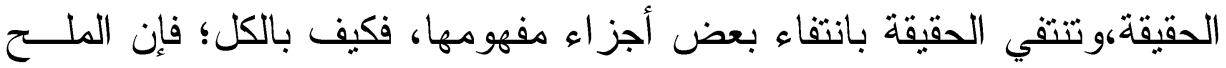

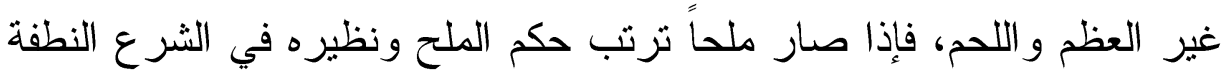
نجسة وتصير علقة وهي نجسة، وتصير مضغة فتطهـر ، و العصـيـير طـــاهر

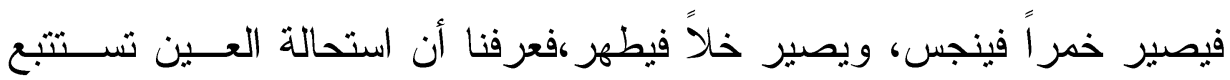
زوال الوصف المترتب عليها.(101)

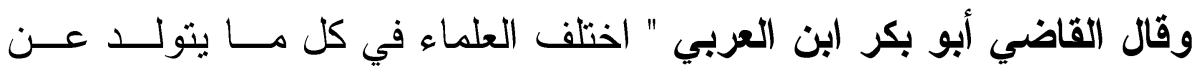

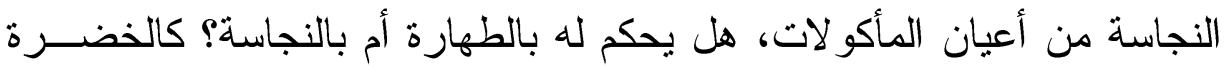

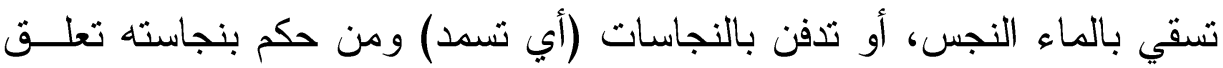

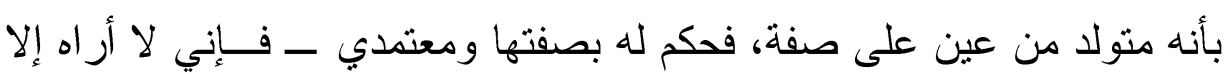

$$
\text { (100) أي تغيرت رائحته ( لسان العرب، مادة (حمأ) 61/1 ). }
$$

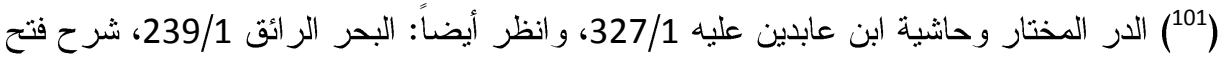

$$
\text { القدير 176/1. }
$$

doi: $10.12816 / 0004230$ 
طاهراً - أن تلك العين النجسة قد ذهبث صفاتها وتغيرت هيئتها، و إنما هـي صفات أخري، فليس الحكم على صفة يكون على أخـرى غيرهـــا، صــفات

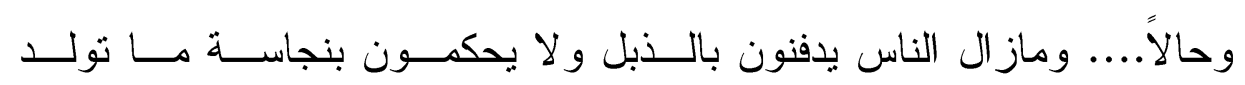
عنه " (102)

وقا علق الحطاب المالكي على جعل المسك (وهو خراج بحدث بــالحيوان تجتمع فيه مو اد تستحيل مسكاً، وتسمى النافحة)، وفأرته (الو عاء الذي يكون فيه المسك) من الأعيان الطاهرة مع أنه ميتة، لأنها يؤخذ من الحيوان حال الحياة،

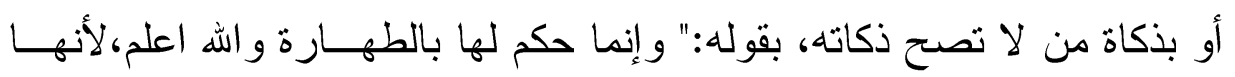
استحالت عن جميع صفات الدم، خرجت عن اسمه إلى صفات واسم يخــص بها، فطهرث لذلك، كما يستحيل الدم وسائر ما يتغذي به الحيوان من النجاسات إلى اللحم فيكون طاهر اً)(103). وجاء في الأخيرة للقر افي " قال اللخمي: قال مالك فــي الكتــاب: لا أكــره الجلالة من الأنعام، ولو كرهت ذلك لكرهت الطير الآكل للنجاسة.......... وأما النبات المسقي بالنجاسة، قال اللخمي:كر هه مالك و أباحه" (104). وقال الشنقيطي" اختلف هل انقلاب أعر اض النجاسة له تأثير في الأحكام أو

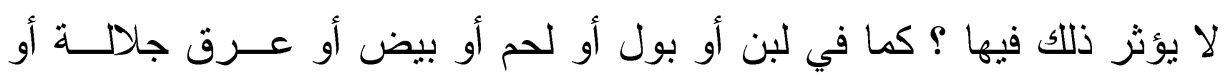

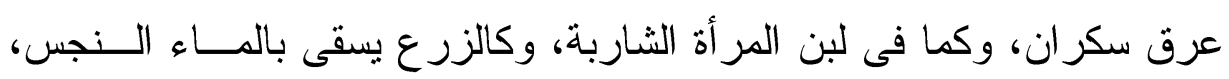

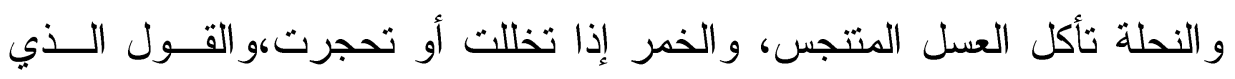

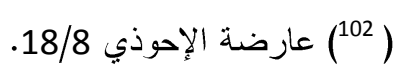

(103) مو اهب الجليل 137/1، 138، و انظر : حاثية الاسوقي و الثرح الكبير 137/1، 52/1، التاج و الإكليل . 138/1

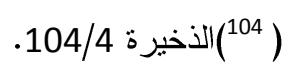


أختاره: أن يكون فيه تفصيل بين ما استحال إلى طاهر، فهو طــاهر كــاللبن

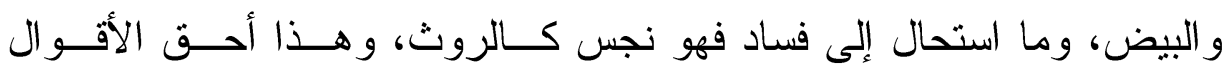
بالصحة، وهو قول يحيي بن عمر (105).

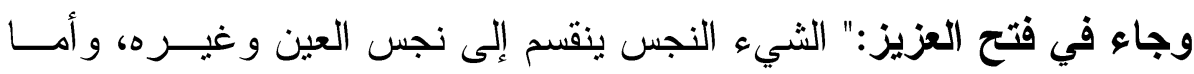

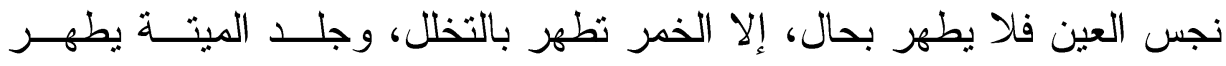

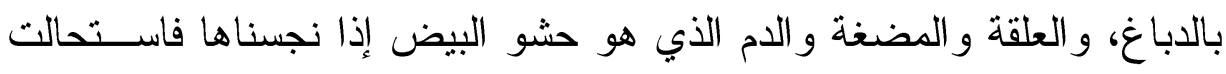

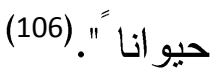

وجاء في الأشباه والنظائر للسيوطي:" لو اعتلفت الثاة حر اماً لم يحرم لبنــاً

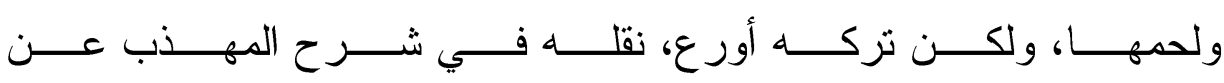
الغز الي" (107).

وجاء في مغني المحتاج: " و لا تكره الثمار التي سقيت بالمياه النجســة،و لا حب زرع نبت في نجاسة كذبل، كما في المجموع عن الأصحاب؛ إذ لا يظهر في ذلك أثرها" (108).

وقال الغزالي:"و أما الزر ع فحلال و إن كثر الذبل فيه، فإنه لا تظهر رائحتــهـ فيبه" (109).

وجاء في إعلام الموقعين لابن القيم" إن الطيب إذا استحال خبيثـاً، صـار

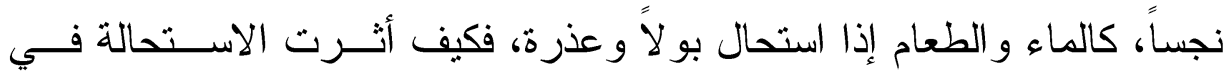

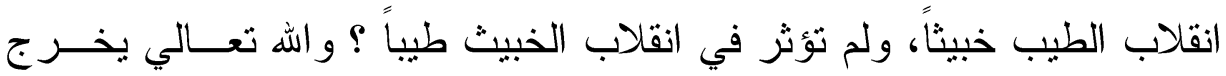

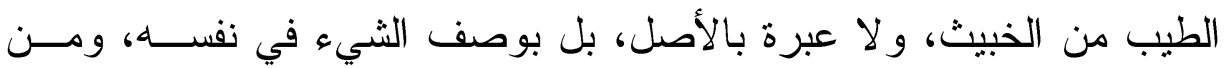

$$
\begin{aligned}
& \text { (105) إعداد المهج للاستفادة من المنهج في قو اعد الفقه المالكي ص } 30 \text { (المز }
\end{aligned}
$$

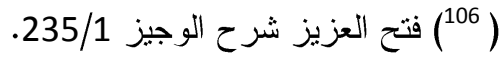

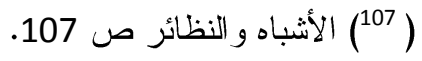

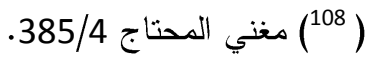

$$
\begin{aligned}
& \text { (109 (105/7) الوسيط في المذهب }
\end{aligned}
$$

doi: $10.12816 / 0004230$ 


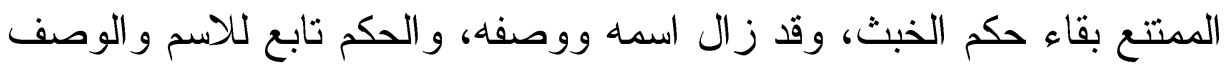
دائر معه وجوداً و عدماً " (110).

وقال شيخ الإسلام أحمد أبن تيمية: " الاستقر اء دلنا على أن كل مأن ما بــــأ الله

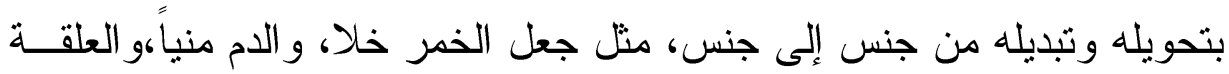

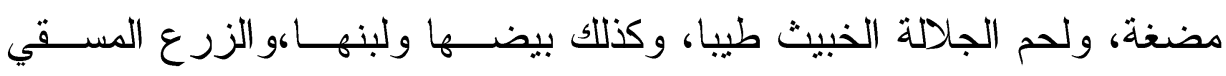

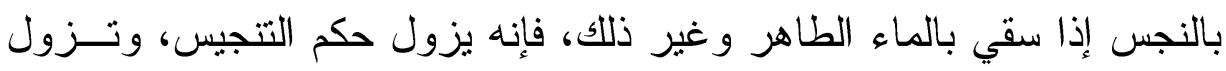
حقبقة النجس، و اسمه التابع للحقيقة، وهذا ضروري لاهي لا يمكن المنازعة فيه، فإن

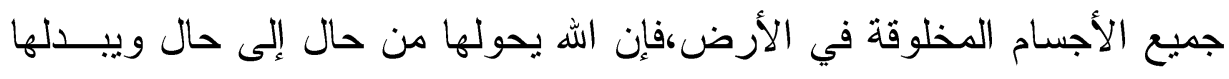

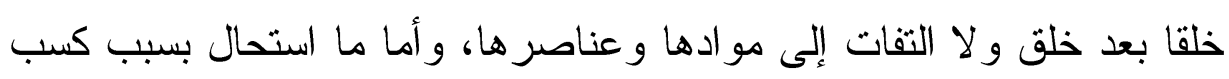

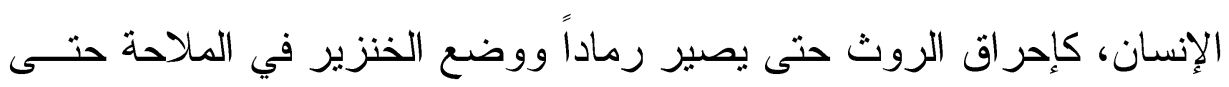
يصير ملحاً، فقيه خلاف مشهور ، وللقول بالتطهير اتجاه وظهور ". (111)

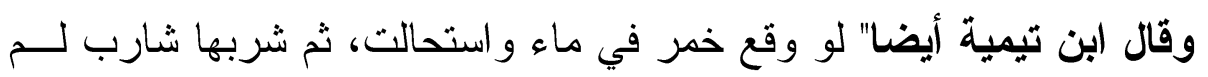

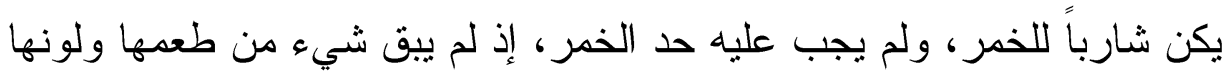

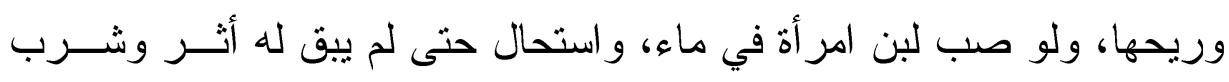
طفل ذلك الماء، لم يصر ابنها من الرضاعة بذلك" (112). وقال الإمام ابن حزم:"الحر ام إذا بطلت صفاته التي بها سمي بذلك الأسم الذي لـي

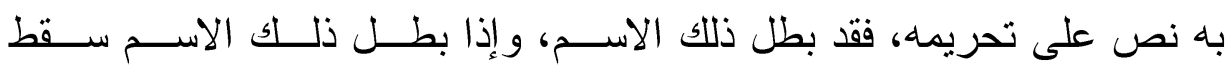
التحريم،لأنه إنما حرم ما يسمي بذلك الاسم كالخمر و الدم و الميتة، فإذا استحال

$$
\begin{aligned}
& \text { 14/2 (110) إعلام الموقعين }
\end{aligned}
$$

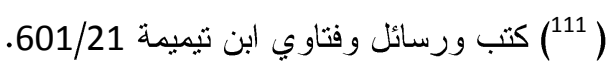

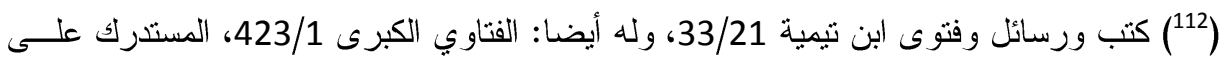
مجموع الفتاوي 12/3. 


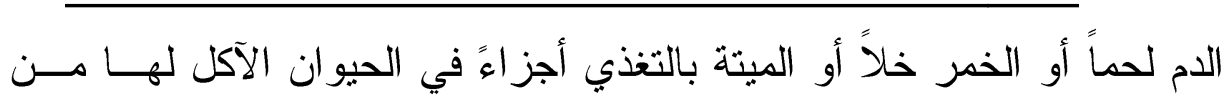

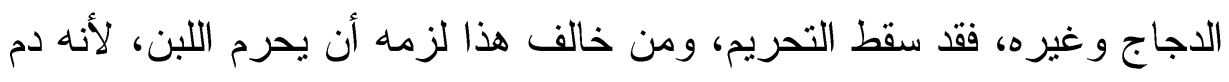

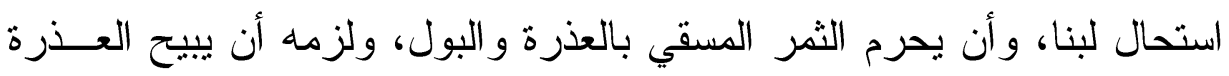

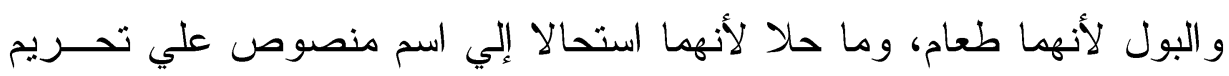

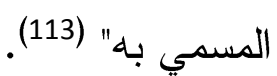
وقال الثوكاني: إذا استحال ما هو محكوم بنجاسته إلى شيء غيــر الثــيء

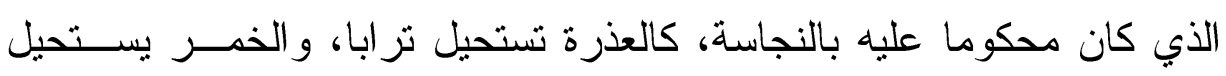
خلا،فقد ذهب ما كان محكوماً بنجاسته، ولم يبق الاسم الذي كان محكوماً عليه

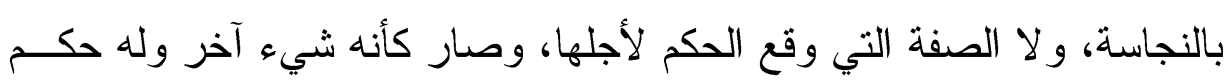
آخر" (114).

يتبين لنا من خلال هذه النصوص المتقدمــة، أن الاســتحالة اســتفعال مــن

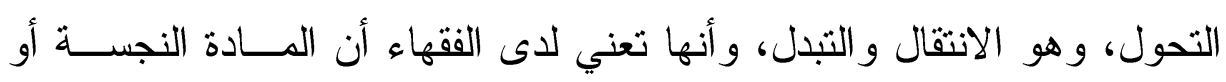

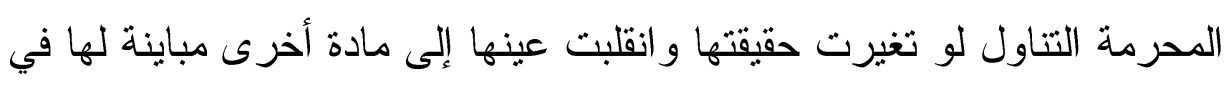

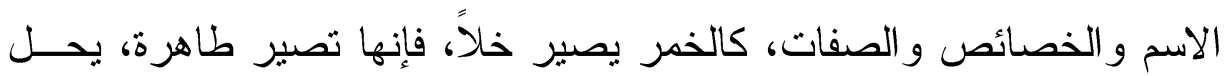

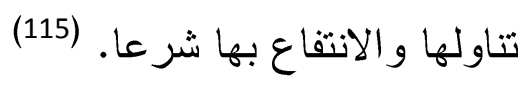

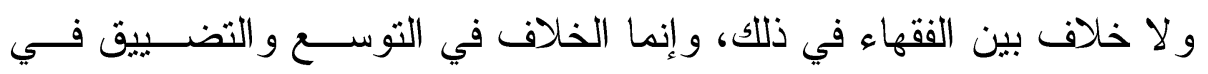

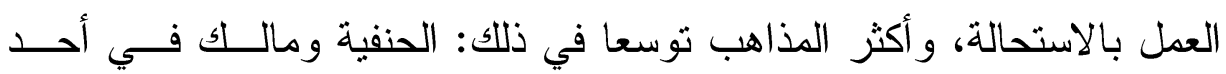

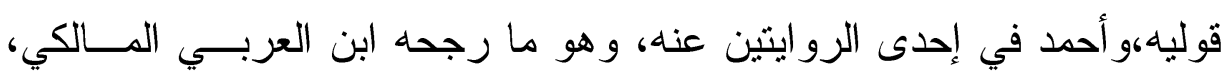

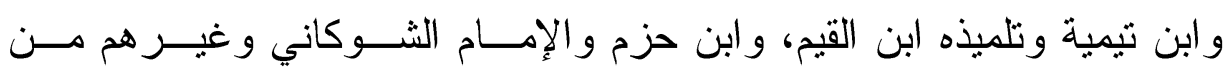
المحققين، و إن كان هناك خلاف بينهم في بعض ولين الفروع و والجزئيات.

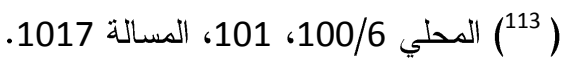

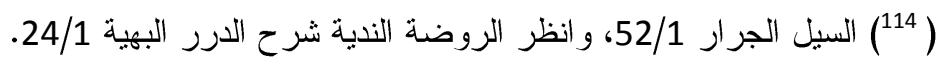

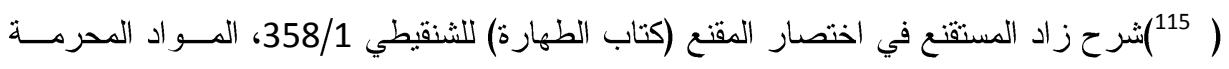

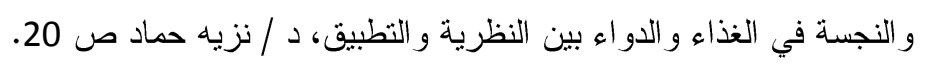
doi: 10.12816/0004230 
جاء في حاشية ابن عابدين " استحالة العين تستتبع زوال الوصــف المرتــب عليها" (116).

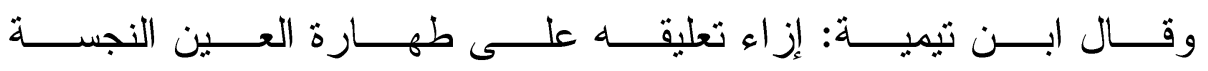

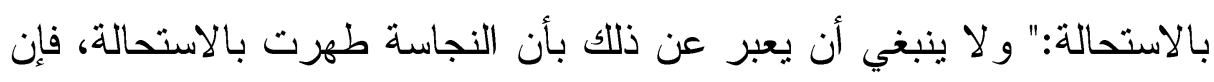

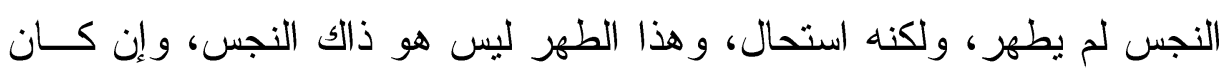
مستحيلا منه و المادة و احدة " (117).

وبناء على كل ما تقدم: فإن تكييف الفقهاء للاستحالة إنما يعني: انقلاب حقيقة

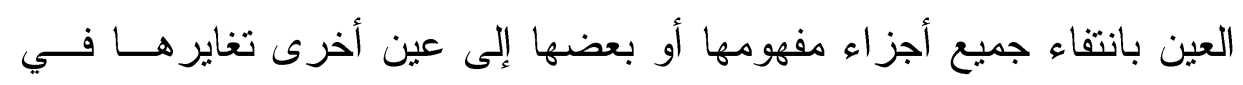

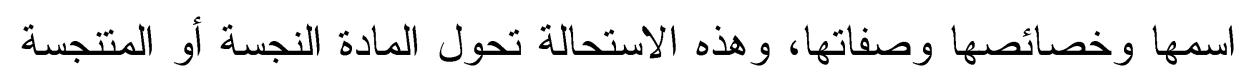

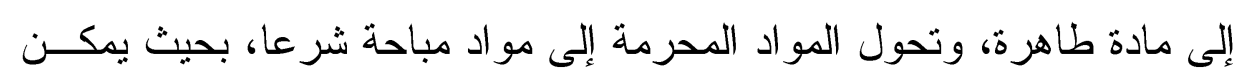

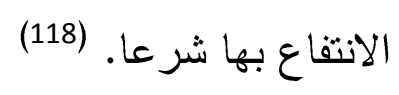

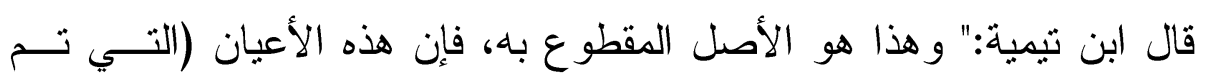

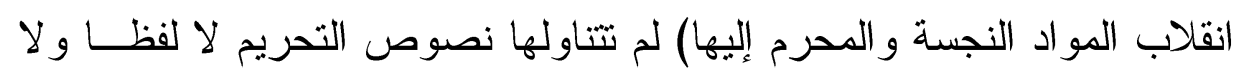

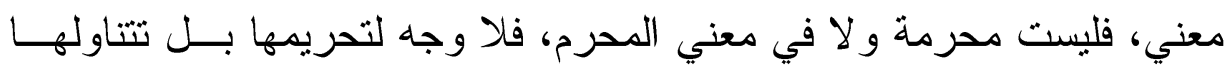

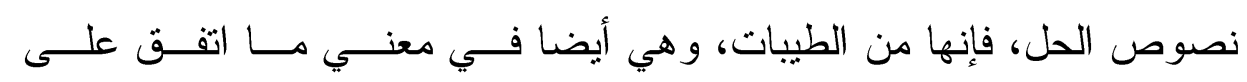
حله،فالنص و القياس يقتضي تحليلها " (119).

327/1 انشية (116)

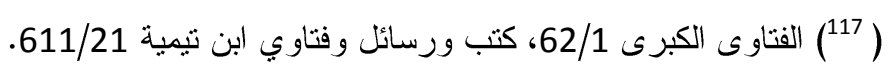

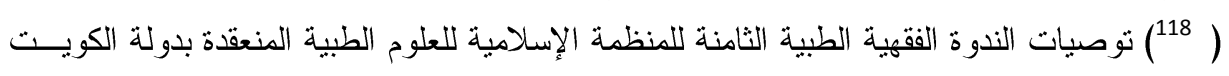

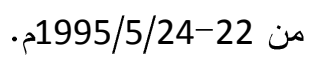
( الفتاوى الكبرى لابن تيمية 235/1، كتب ورسائل وفتاوى ابن تيمية 7/21. 


\section{المبحث الثالث}

\section{استحالة المياه النجسة إلي طاهرة للانتفاع بها في الفقه الإسلامي}

\section{تقديم:}

يليق بالبحث قبل تتاول هذا البحث، أن يبـين مفهـوم الــنجس فـي اللغـــة و اصطلاح الفقهاء.

ففي اللغة: النَّس و النِّس و النَّجس، القذر من الناس ومن كل شيء قذرته، وتقول: نجس الشيء (بكسر الجيم) ينجس نجساً فهو نجس ونجس إذا كان قذراً غير نظيف، و الجمع أنجاس (120). ونجس خلاف طهر ، و الاسم النجاسة، و النجاسة ضد الطهارة.(121). ثم فالنجس

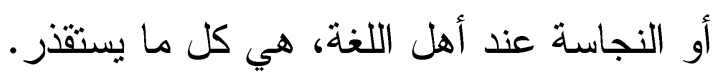
أما في اصطلاح الفقهاء:

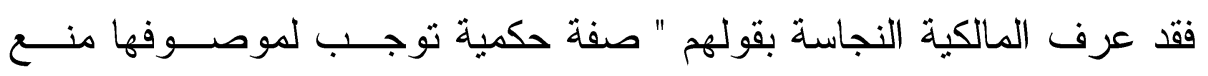
استباحة الصلاة به أو فيه " (122). و المر اد بقولهم (به) محمول المصلي (وفيه) مكان المصلي (123). و عند الثافعية، النجاسة:" مستقفر يمنع صحة الصلاة " (124). و عند الحنابلة، النجس " هو الشيء المستقذر " (125).

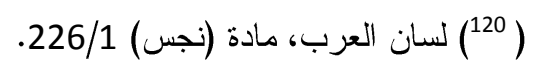

(221) المصباح المنير، مادة (نجس) ص 227، 220 نهذيب اللغة، مادة (نجس) 462/3.

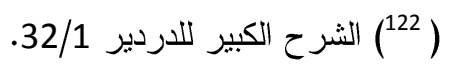

32/1 (223) حاثية الدسوقي و الثرح ح الكبير

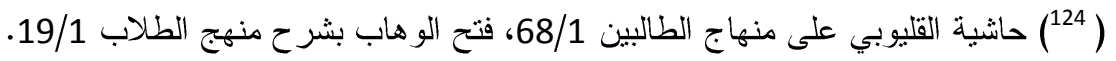

(25) شرح ز اد المستقنع للثنقيطي 2/8. 
يتبين من هذه التعريفات أن النجس أو النجاسة عند الققهاء، هو المستقذر الذي يحرم تتاوله أو تعاطيه - كالمبتة و الدم ولحم الخنزير - ويمنع جنسه استباحة الصلاة كالبول و العذرة، فكل ما اتصف بالنجاسة من الأشياء نوعين: الأول: نجس العين، كالبول و الغائط والميتة و الدم ولحم الخنزير ، وهذا يحرم

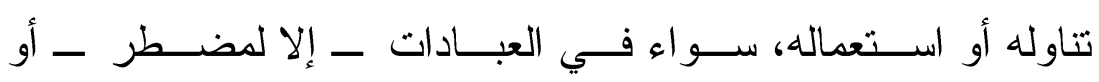
العبادات. (126)

الثاني: المتتجس، وهو ما كان غير نجس في أصله، ولكنه اكتسب النجاســة من غيره، كالماء المتتجس و الثوب المتتجس. قال الإمام الكاساني:" الماء النجس هو ما خالطته النجاسة " (127).

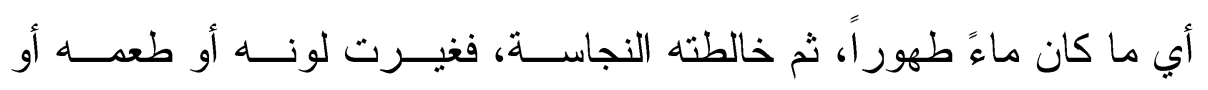
رائحته، فيحرم استعماله في العادات من أكل أو شرب أو طبخ أو عجن ونحو ذلك - إلا لمضطر - و العبادات باتفاق الفقهاء. يقول العلامة ابن المنذر :"و أجمعوا على أن الماء القليل و الكثير إذا وقعت فيه نجاسة، فغيرت الماء طعماً أو لوناً أو ريحاً، أنه نجس مادام كذللك"(128). وقال ابن رشد الحفيد" واتفقو اعلى أن الماء الذي غيرت النجاسة إما طعدــهـ

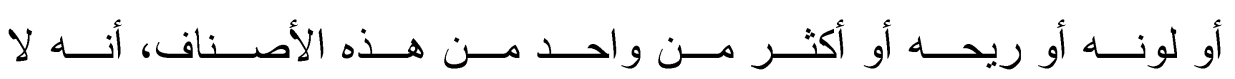
يجوز به الوضوءء ولا الطهور" (129).

$$
\begin{aligned}
& \text { (289/6، 289/6 فتح العزيز شرح الوجيز 235/1 وما بعدها. }
\end{aligned}
$$

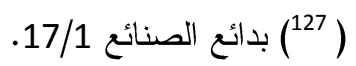

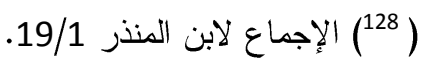

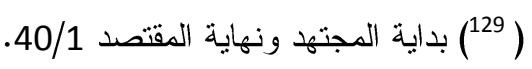


و النجاسة قد تكون حسية، وهي المشاهدة بحاسة البصر، كالبول و العذرة وقد تكون معنوية كالمعاصي الظاهرة (كالزنا و السرقة و القتل) و الباطنــة كــالكبر و الرياء و العجب و النفاق. (130)

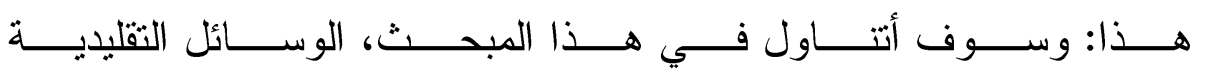

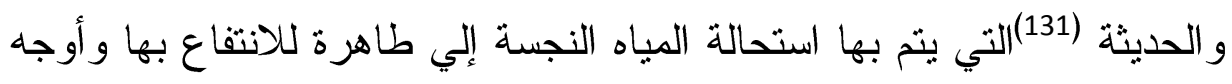

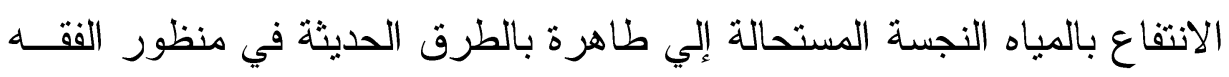
الإسلامي من خلال ثلاثة فروع كالتالى:

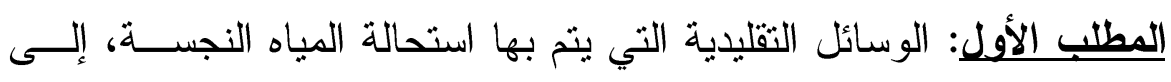

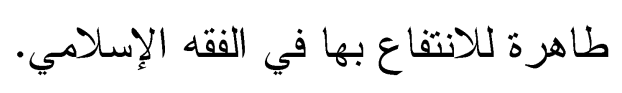

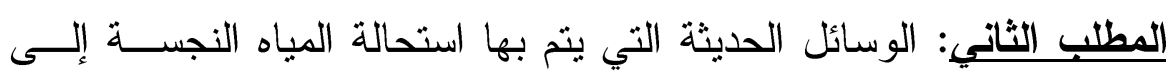
طاهرة للانتفاع بها.

المطلب الثالث: أوجه الانتفاع بالمياه المستحالة إلى طاهرة بالطرق الحديثة في منظور الفقه الإسلامي.

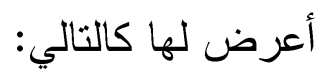

\section{المطب الأول}

الوسائل التقليدية التى يتم بها استحالة المياه النجسة إلى طاهرة للانتفاع

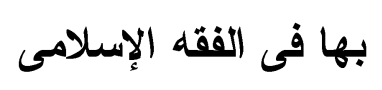

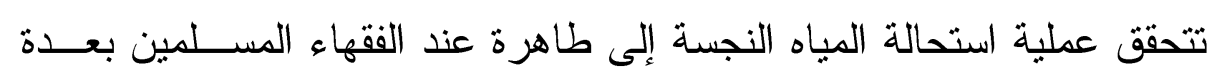

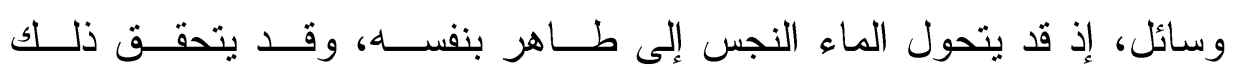

( مانشية الدسوقي على الثرح الكبير 30/1، حاشية العدوي على شرح الخرشي 60/1، روح

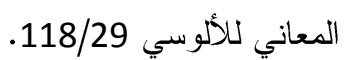

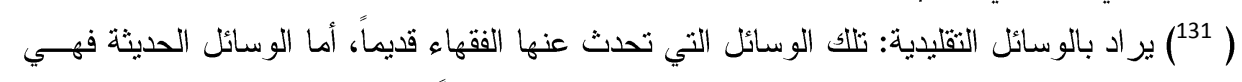

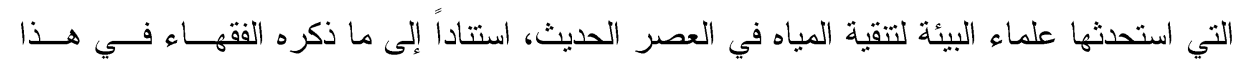




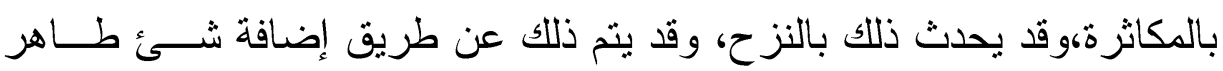

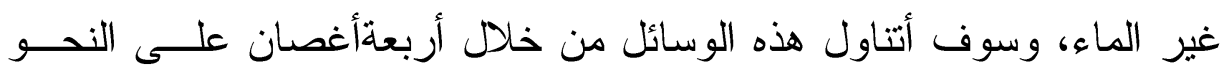
التالى:

\section{الفرع الأول}

الوسبئة الأولى: استحالة الماء النجس إلى طاهر بنفسه الاول

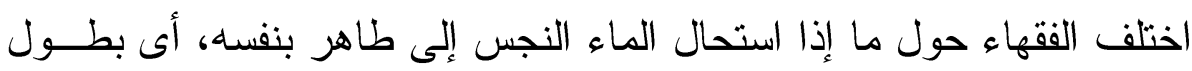

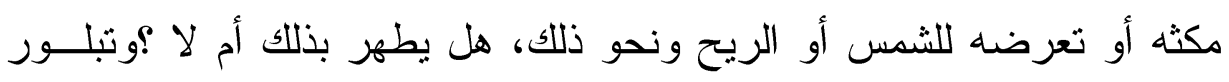

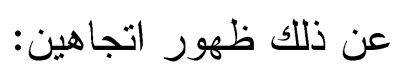

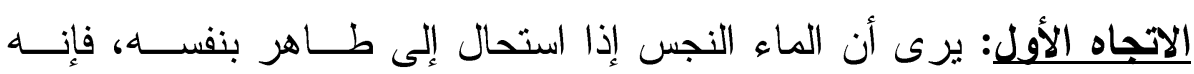

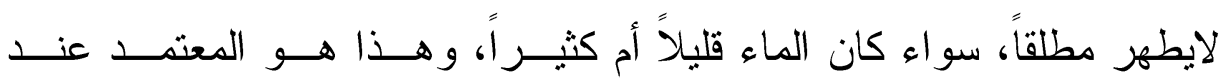

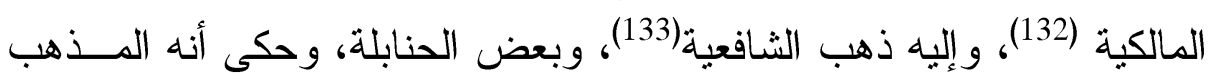
عندهم) (134).

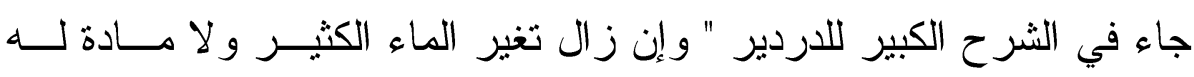

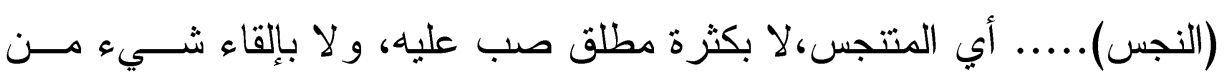
تر اب أو طين بل بنفسه...... فاستحسن الطهورية لذلك الماء........ (وعدمها) أي الطهورية..... أرجح، وهو المعتمد، و الأول ضعيف". (135)

(132) الثرح الكبير للاردير 46/1، شرح الخرشى 118/1، 80/18/1، الذخيرة 161/1، مو اهــب الجليـلـ

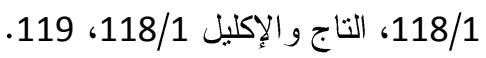
(133) الحاوى الكبير 139/1، المجموع 132/1، 13/1، روضة الطالبين 13/1/18/1، 131/، مغنى المحتاج 36/1،

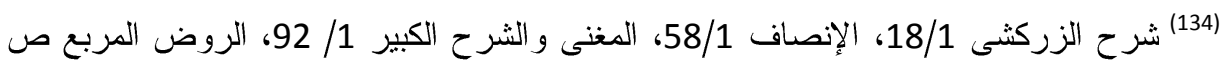
44، شرح منتهى الإز ادات 100/1.

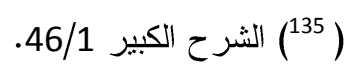


وقد استنل أصحاب هذا الاتجاه على ما ذهبوا إليــهـ بـــالمعقول، فقــالو ا: إن

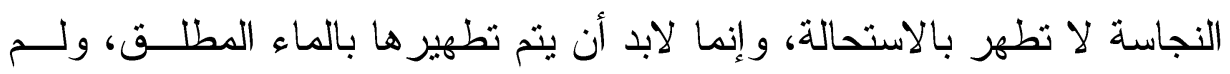

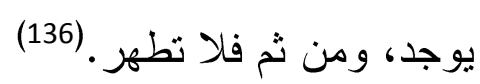

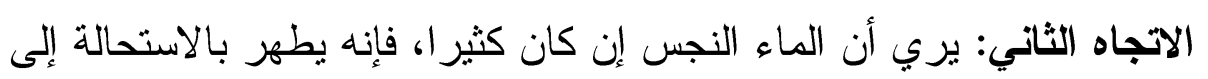

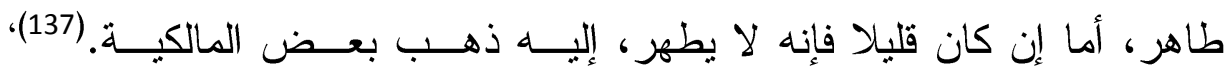

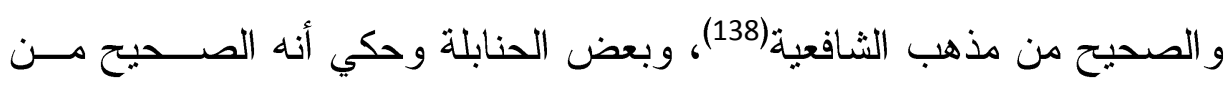

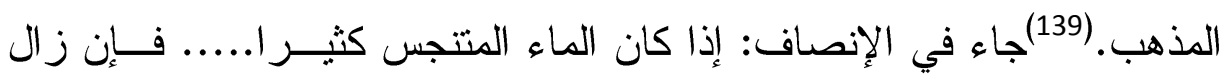
تغيره بمكثه طهر على الصحيح من المذهب، جزم به في الرعاية الكبرى، وهو الصهاه ظاهر كلام كثير من الأصحاب " (140. وقد استدل أصحاب هذا الاتجاه على ما ذهبو إلبيه بالمعقول من وجهين:

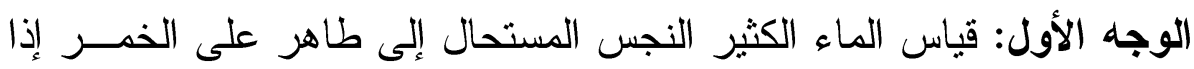
انقلبت خلاً، فكما يطهر الخمر بالاستحالة إلى خل طاهر، فئ فكذلك الماء الكثيــر (141)

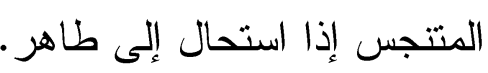

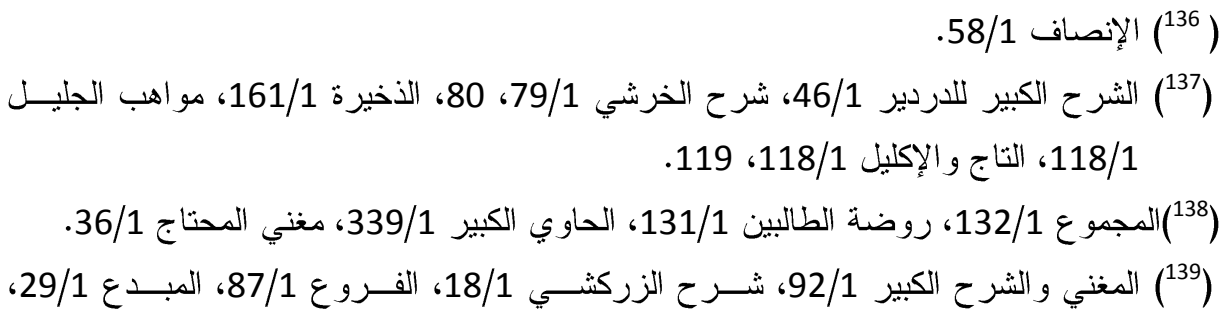

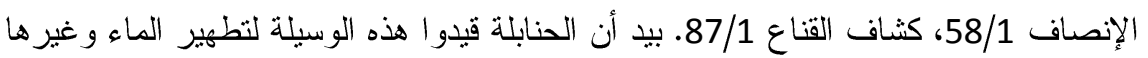

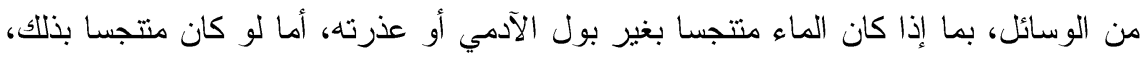

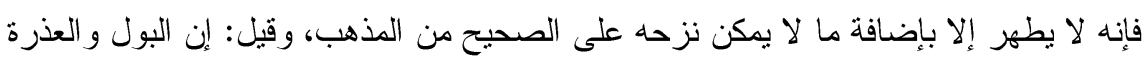

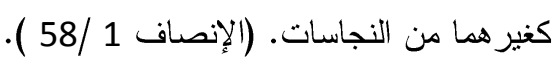
.58/1 الإنصان (258) (المغني و الثر ح الكبير ، المصدر السابق. 
الوجه الثاني: أن العلة في تتجنيس الماء الكثير هي التغير، وقد زال تتجسيه بزو ال علته كالخمر إذا صار خلاً ؛ لأن الحكم يدور مع علته وجوداً و عدماً،أما

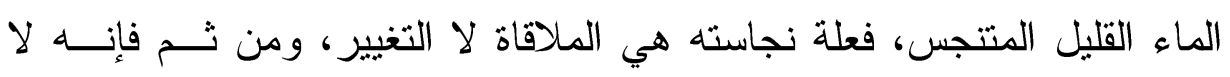
يطهر بالاستحالة إلى طاهر، لعدم زو ال علته. (142) الر اجح:

يتزجح لدي أن الماء النجس منى استحال، فالماء طاهر قليلاً كان أم كثيراً إذ إنه يدخل حالئذ فى حد الطيب الخارج عن الخبث , وقد صح قول المعصــوم صلى الله عليه وسلم: "الماء الطهور لا ينجسه شيء " (143). وهو عام في القليل

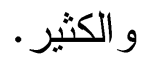

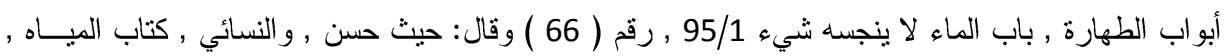

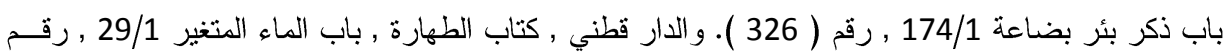
359/17 


\section{الفرع الثاني - (النجي}

\section{الوسيلة الثانية: استحالة الماء النجس إلى طاهر بالمكاثرة}

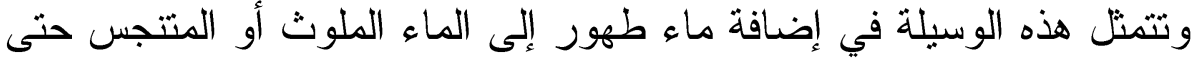

يزول عنه هذا الوصف , ويستحيل ماءٌ طهوراً , هذا ما ذهب إلهاء إليه عامة فقهاء الإسلام (144).

قال العلامة الخرمشي: " ما زال تغيره بمكاثرة ماء مطلق خالطـــهـ طهــور باتفاق " (145).

وقد استدل الفقهاء على ما ذهبو إليه بالمعقول من وجهين:

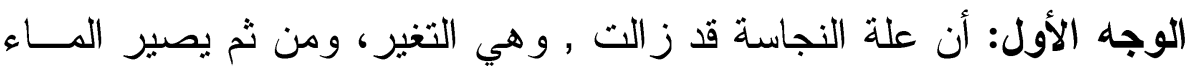

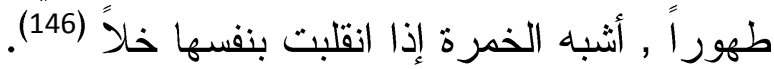

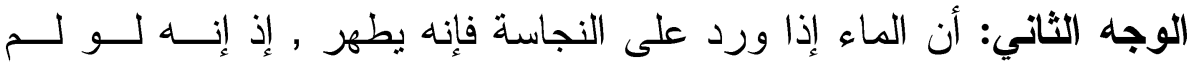

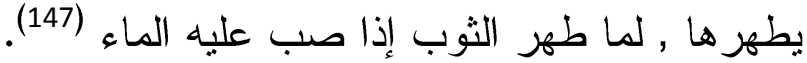
بيد أن الفقهاء قد اختلفو احول كيفية تحول الماء المتتجس بهذه الوسيلة.

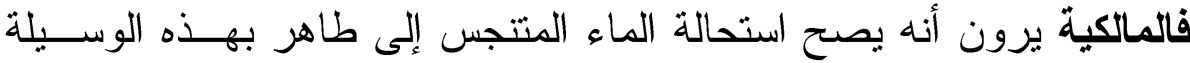

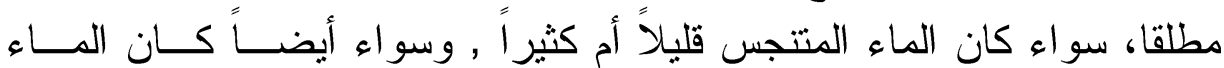
المضاف قليلاً أم كثيرًا (148).

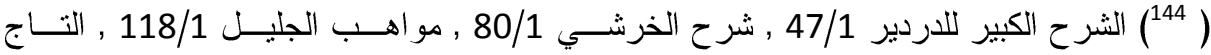

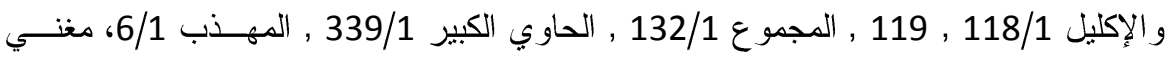

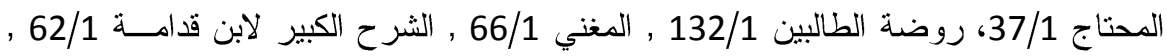

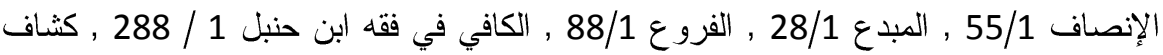

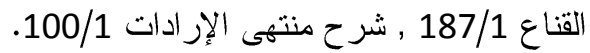

$$
\begin{aligned}
& \text { (145) شرح الخرمشي 80/1) } \\
& \text { (146) المجموع 132/1 , المهذب 6/1 6 136/1 الثرح الكبير لابن قدامة 62/1. }
\end{aligned}
$$

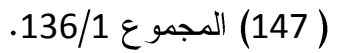

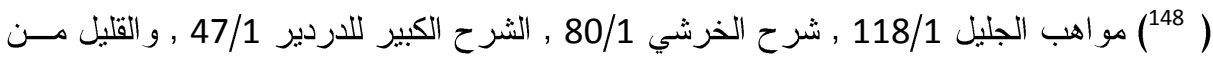

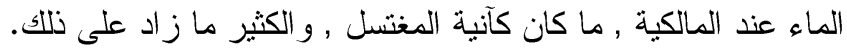


أما الشافعية: فيفرقون بين ما إذا كان الماء المتتجس قليلاً أم كثيراً وحد الماء

القليل عندهم: ما لم يبلغ قلتين (149). أما الكثير : فهو ما بلغ قلتين فأكثر (150). فإذا كان الماء المتتجس قليلاً ( أقل من قلتين ) فيشترط أن يبلغ بعد المكاثرة قلتين.

أما إذا كان الماء المتنجس كثيراً ( قلتين فـأكثر ) فإنـــهـ بســتحيل طهــوراً

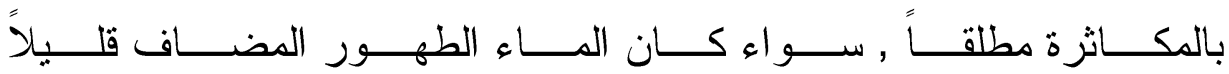

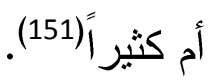

وقد استذلو ا على ذهبوا إليه بالسنة النبوية المطهرة , وهو حديث عبد الله بن عمــر ( رضـــي الله عنهمــــا ) أن النبـــي ( صـــلـى الله عليـــهـ وســلم ): قال:" إذا بلغ الماء قلتين لم يحمل الخبث " وفي رواية " لم ينجسه شيء" (152).

(149) القلة: هي الجرة , وسميت قلة , لأنها تقل بالأبدي , أي: تحمل , ويقع هذا الاسم على الكبيـرة

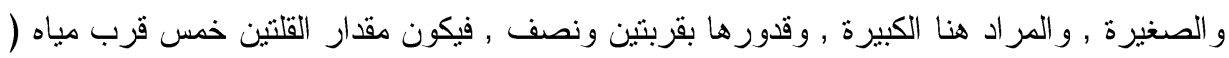

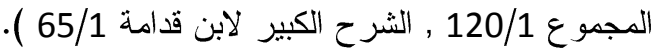

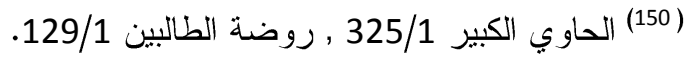

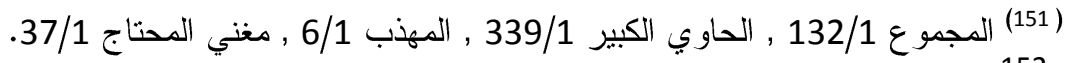

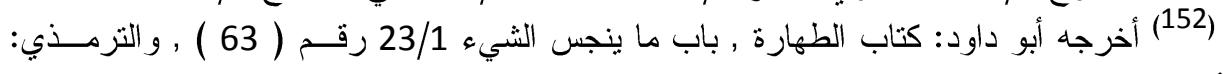

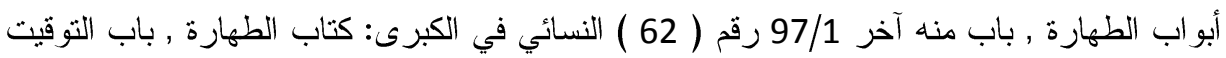

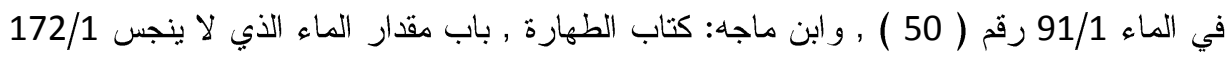

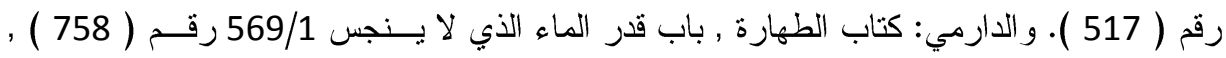

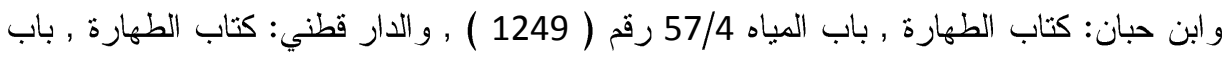

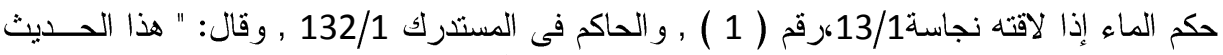

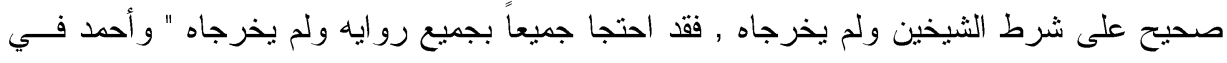

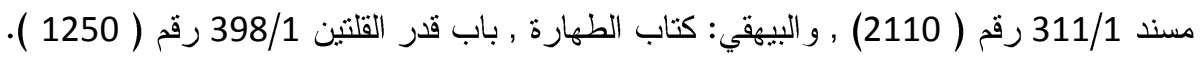
وقد اختلف في صحة هذا الحديث , فصححه جماعة من أهل الحديث منهم: الإمام ابن حجر و الحاكم و ابن دقيق العيد و الكثناوي و الخطابي , وضعفه ابن عبد البر و القاضي إسماعيل و الطحاوي و ابــن الطن

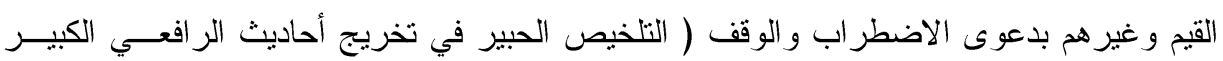
261 
وجه الدلالة: الحديث يدل على أن الماء إذا بلغ قلتين , لم يحمل الخبث , أي

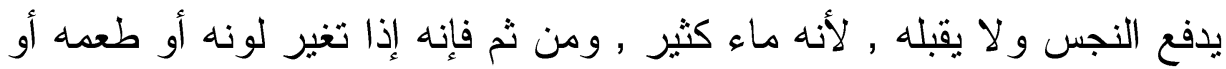

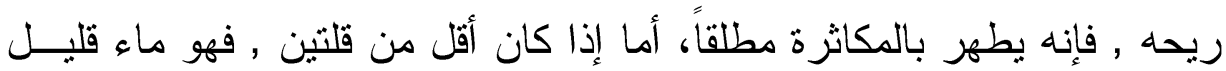

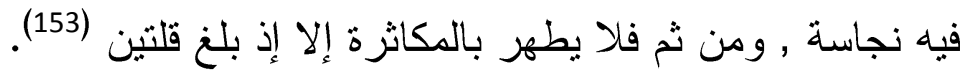

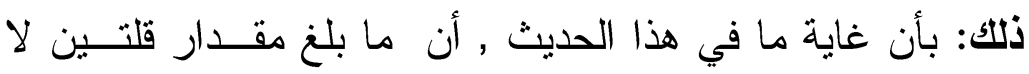

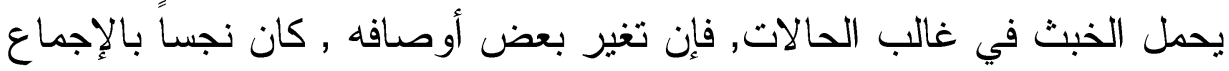

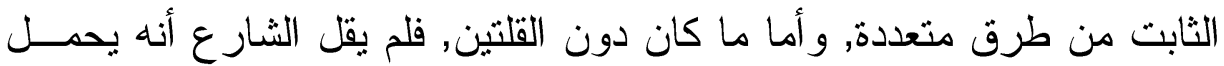

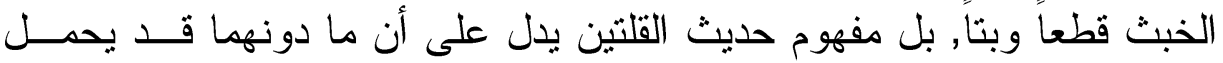

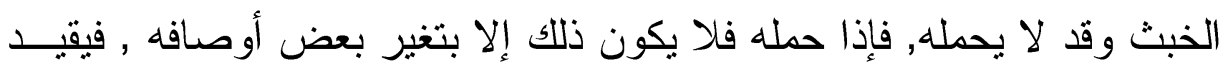

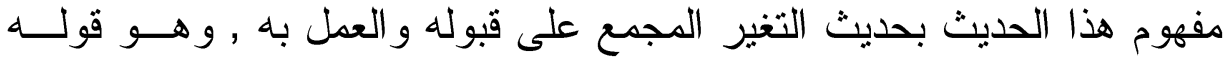

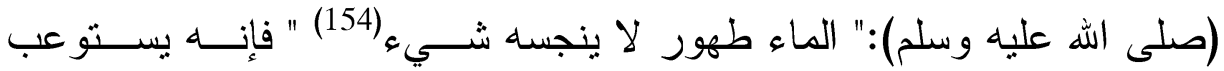
القلتين وما دونهما بإجماع العلماء (155).

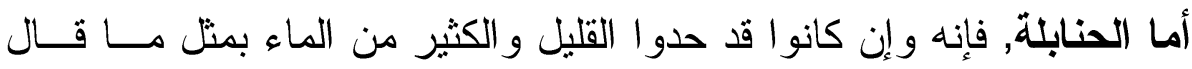
الثافعية (156), إلا أنهم يشترطون لاستحالة إنهائل الماء المتجنس طهوراً بهذه الوسيلة

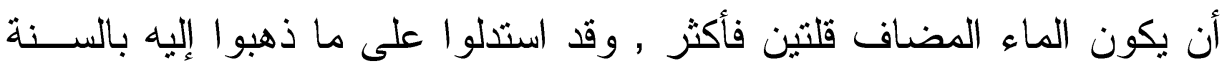
و المعقول.

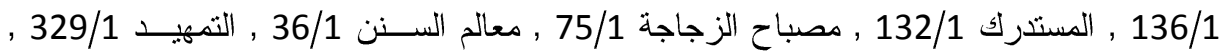
تهذيب سنن أبي داود 36/1 - 43 ).

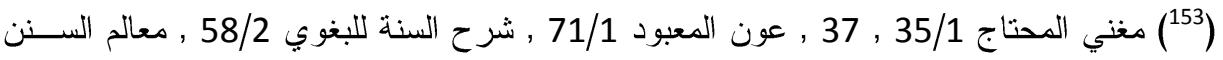
$.36,35 / 1$

$$
\text { 261) سبق تخريجه صـ (154) }
$$

37 / بتصرف من السيل الجرار 1 (155)

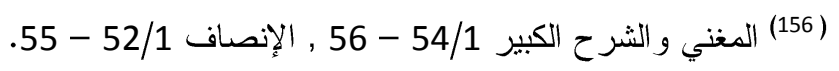


أما السنة: فحديث ابن عمر السابق عن النبي (صلى الله عليه وسلم)أنه قال:"

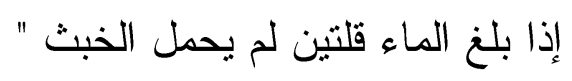
وجه الدلالة:

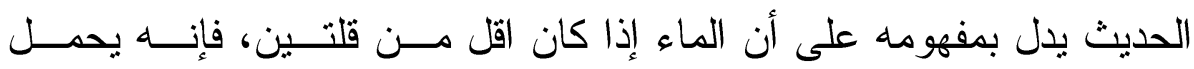

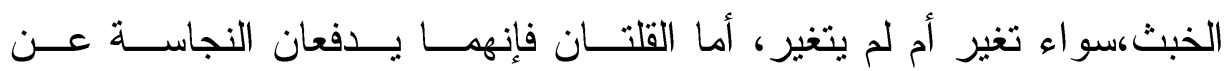

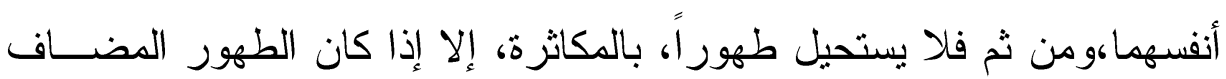
مقدار قلتين أو أكثر. (157)

أجيب عن هذا الاستدلال: بما أجيب به على استدلال الشافعية آنف الذكر. أما المعقول: فاستدلو ا به فقالو ا: إن القلتين لا تحملان الخبث ولابل ولا تتجسان إلا

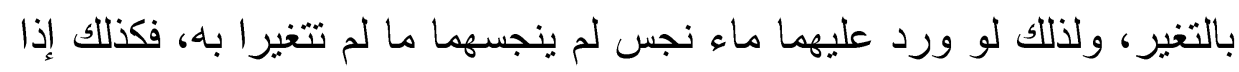
كانتا واردتين، ومن ضرورة الحكم بطهارتهما، طهارة ما اختلطا بهها. (158) والر اجح: - والج

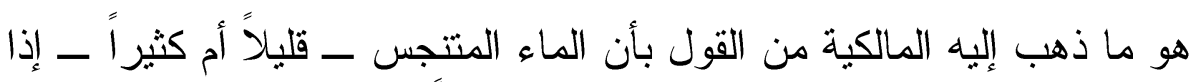

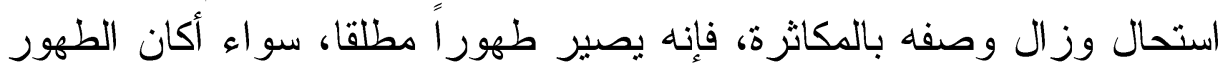

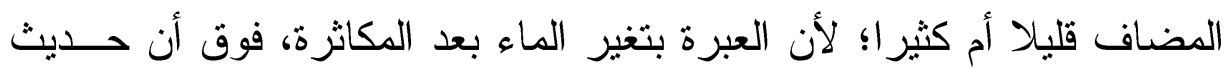

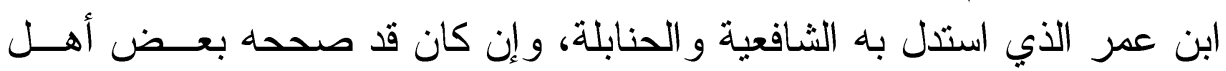

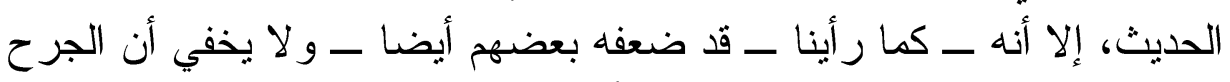

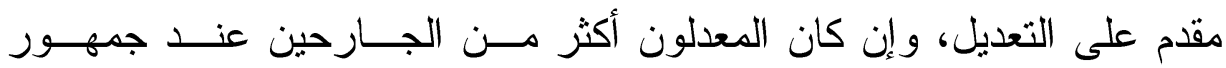
الأصوليين (159)، فلا يدفعه تصحيح بعض كان المعدون المحدثين له. له.

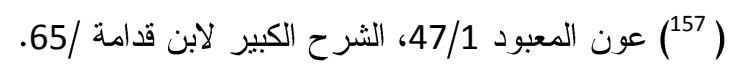

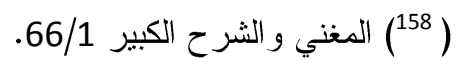
(159) إرشاد الفحول 184/1 ـ ـ الإبهاج في شرح المنهاج 322/2، رفع الحاجب عن مختصر ابـن

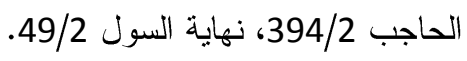




\section{الفرع الثالث}

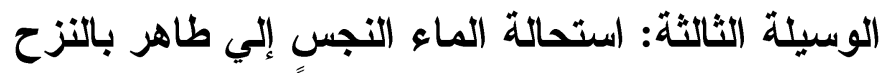

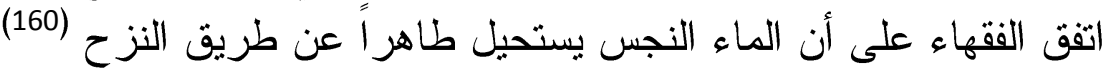

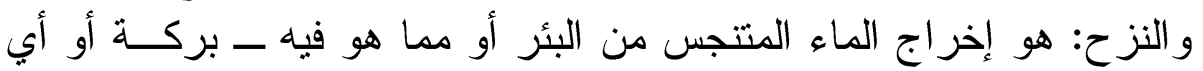

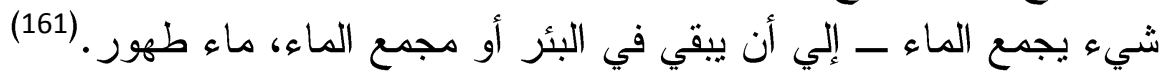

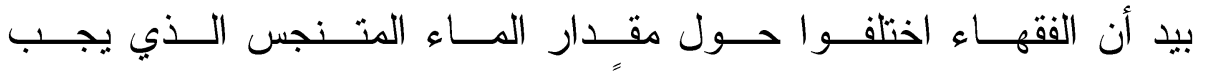

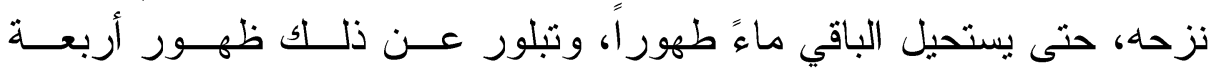
اتجاهات: الاتجاه الأول: يري أن الماء المتنجس لا يستحيل طهورًا إلا بنزح جميع الماء

$$
\text { إليه ذهب الحنّز الحنية. (162)، وبعض المالكية (163). }
$$

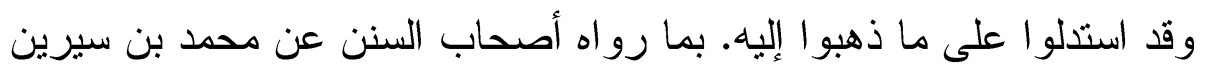

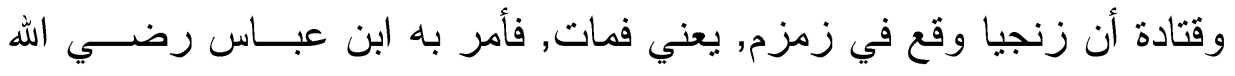

(160) بدائع الصنائع 74/1، مو اهب الجليل 115/1، المجموع 132/1، المغني 66/1.

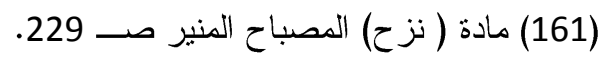

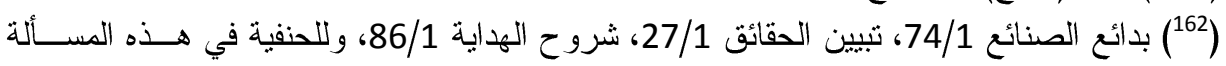

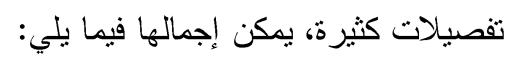

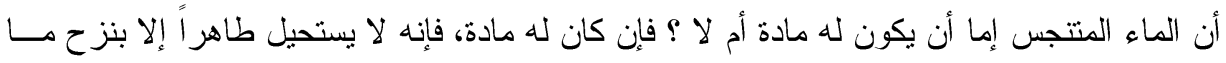

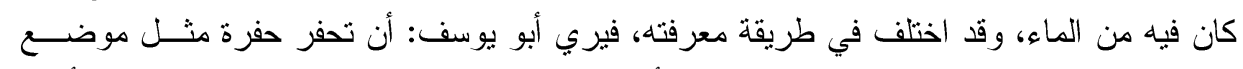

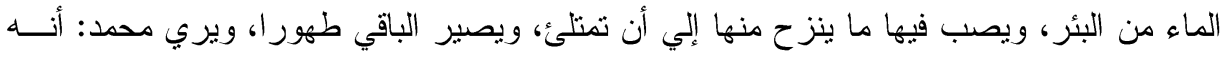

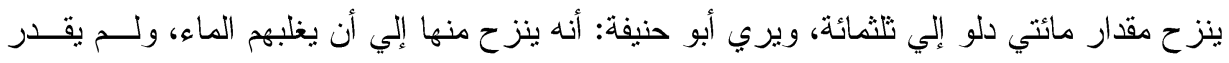

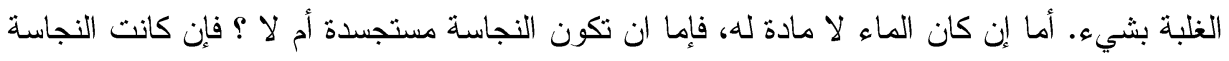

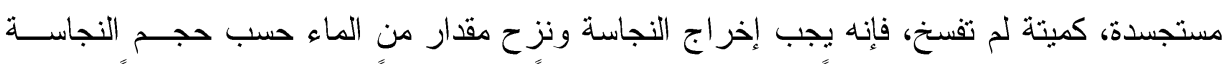

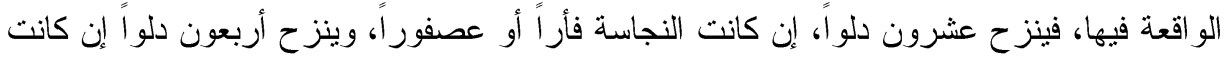

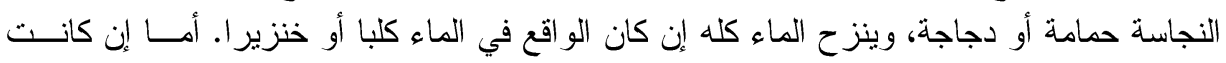

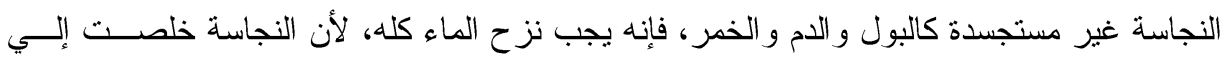

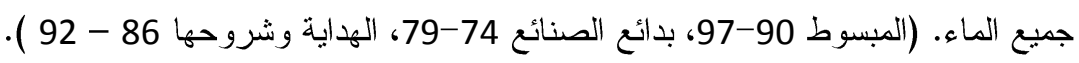

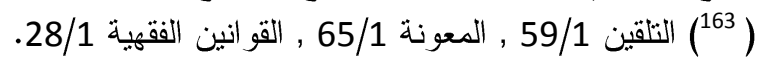
doi: 10.12816/0004230 
عنهما, فأخرج و أمر بها أن تنزح (164). وبما روى عن هشيم عن منصور عن

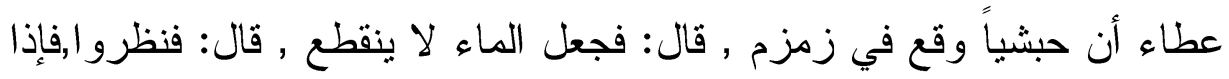

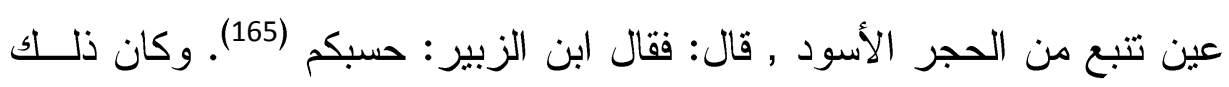

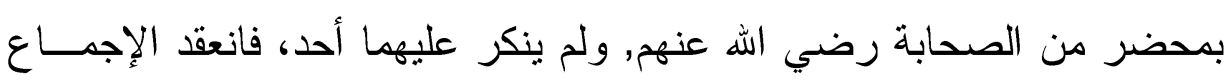
عليه (166).

\section{نوقش هذا الاستدلال من وجوه:}

الوجه الأول: أن هذا خبر ضعيف لا يصح الاحتجاج به , يؤيد ذلك ما يلي:

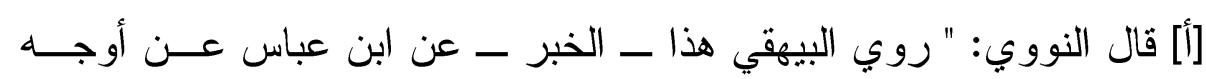

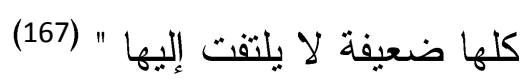

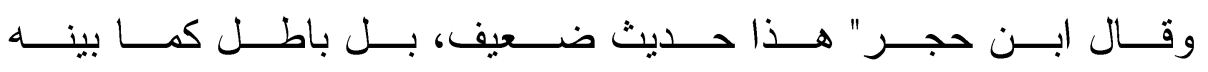
النووي " (168). وقال البيهقي تعليقا على رواية ابن سيرين وقتادة لهذا الخبر : "

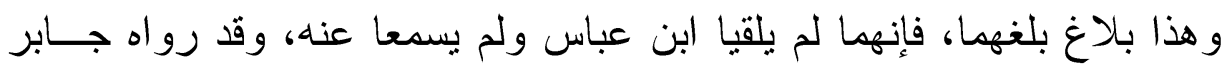

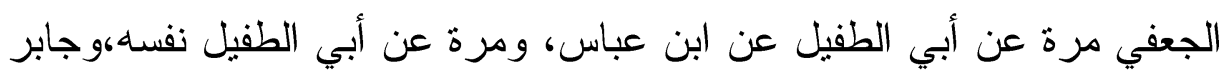

(164) أخرجه الدار قطني من طريق ابن سيرين , كتاب الطهارة , باب البئر إذا وقع فيهــا حيـــوان

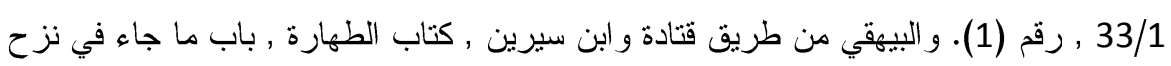

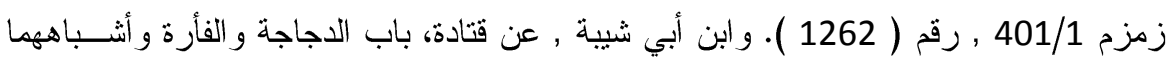

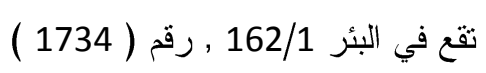

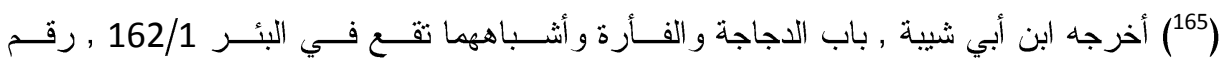

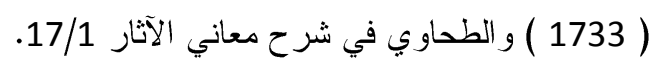

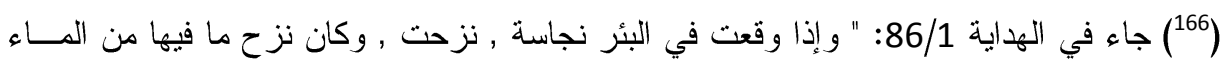

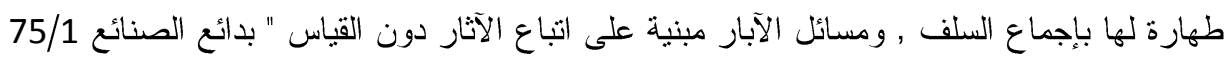


الجعفي لا بحتج به. ورو اه ابن لهيعة عن عمرو بن دينار، وابن لهيعة لا يحتج (169) ب.

أجيب عن ذلك:...... بأن بعض علماء الحديث و غير هم قد صحح هذا الأثر

وذكروا أن ابن أبي شيبة و الطحاوي قد روياه عن عطاء بسند صحيح. (170) [ب] زعم أهل العلم من سكان مكة.... أنهم لا يعرفون هذا الخبر عـن ابـن عباس، فكيف يصل إلي أهل الكوفة، ويجهله أهل مكة. قال أبو عبد الله الشافعي: " لا نعرفه عن ابن عباس، وزمزم عندنا، ما سمعنا بهذا، وقد سمعت سفيان بن عيينة يقول: أنا بمكة منذ سبعين سنة، لم أر أحــداً صغيراً و لا كبيراً، يعرف حديث الزنجي الذي قالو إنه وقع في زمسزم، مهـا سمعت أحداً يقول نزح زمزم " (171). وقد علق النووي على ذلك بقوله:" وهذا سفيان كبير أهل مكة، قد لقي خلائق من أصحاب ابن عباس، وسمعهم فكيف يتو هم بعد هذا صحة هذه القصة، التي من شأنها إذا وقعت أن تشيع في الناس، لا سيما أهل مكة، لا سيما أصــحاب ابن عباس وحاضروها، وكيف يصل هذا إلى أهل الكوفة ويجهله أهل مكة"(172).

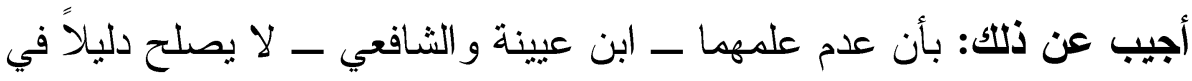
دين الله تعالي، ثم إنهما لم يدركا ذلك الوقت، فبينهما وبينه قريب مــن مائــة

$$
\begin{aligned}
& \text { 401/1 (السنن الكبري (169) } \\
& \text { (170) مرفاة المفاتيح 404/2، شرح فتح القدير 91/1، مصنف ابن أبي شيبة 162/1، شر ح معاني } \\
& \text { الآثار 17/1. }
\end{aligned}
$$

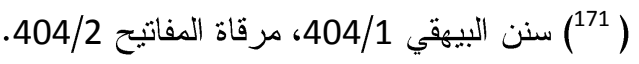

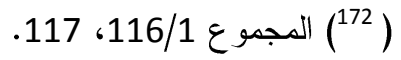

$$
\begin{aligned}
& \text { doi: } 10.12816 / 0004230
\end{aligned}
$$


وخمسين سنة، وكان إخبار من أدرك الو اقعة و أثبتها أولي من قولهـــــ " (173). لأن الخبر المثبت مقدم على النافي، كما قال علماء الأصول (174).

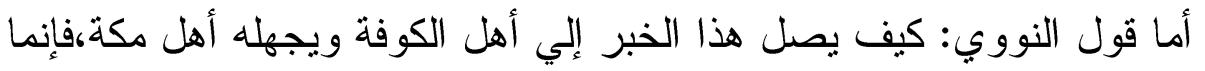

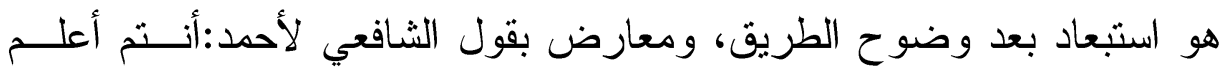

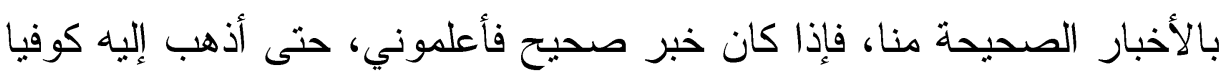

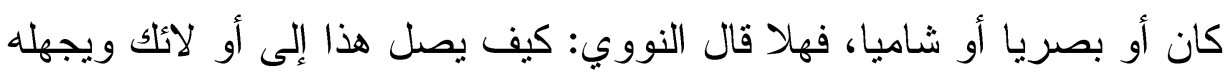

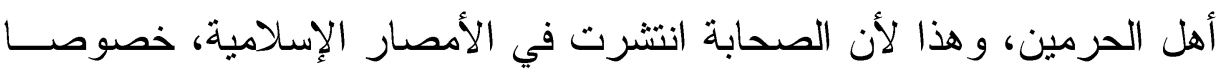
العر اق. (175)

الوجه الثاني: لو سلمنا بصحة هذا الأثر، فإنه يحمل على أن ماء زمزم قـــ تغيرت بموت الزنجي فيها، لأن دمه ظهر على وجه الماء حتى رئي فيه. (176)

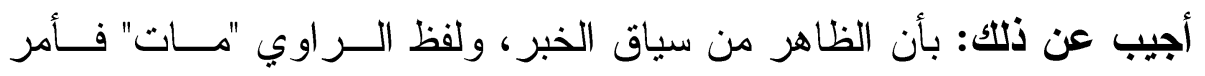

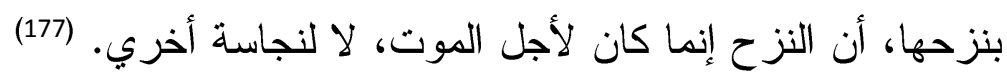

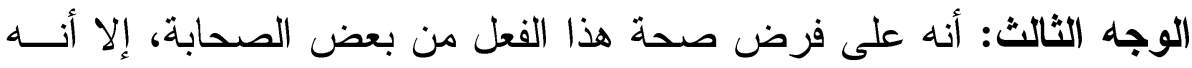

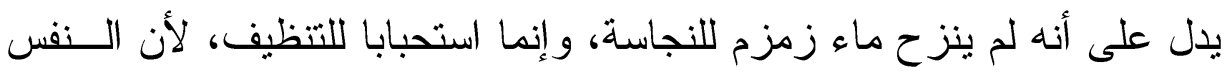

$$
\begin{aligned}
& \text { (173)نصب الر اية 129/1، شر ح فتح القدير 91/1، مرقاة المفاتيح 404/2، 405. } \\
& \text { (174) البحر المحيط في أصول الفقه 273/2، التحبير شرح التحرير 1350/3، شرح الكوكب المنير } \\
& .113 / 2 \\
& \text { (175) نصب الر اية 130/1، مرقاة المفاتح 2/2 405، شرح فتح القدير 91/1. }
\end{aligned}
$$

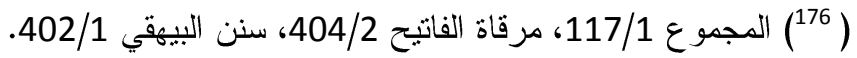

$$
\begin{aligned}
& \text { (177) شرح فنح القدير 91/1، مرقاة المفاتيح 404/2، } 405 \text { (117/1 }
\end{aligned}
$$


تعافه، وزمزم للشرب، ويؤيد ذلك ما رواه عبد الله ابــن عبــاس رضـــي الله

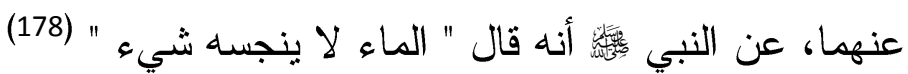

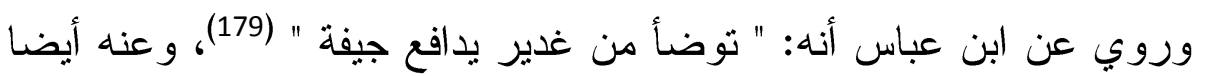

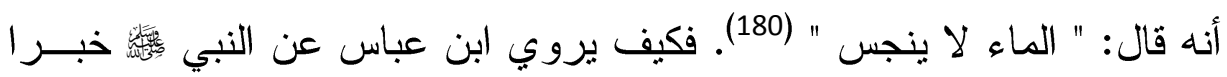
او يفعل أو يقول شيئا ويتركه. (181)

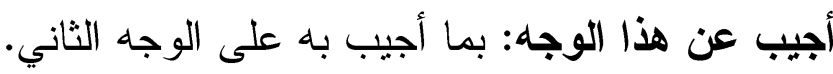

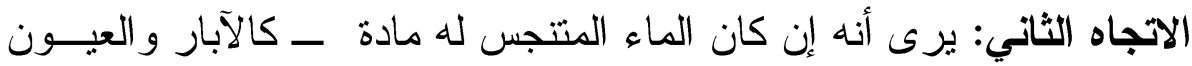

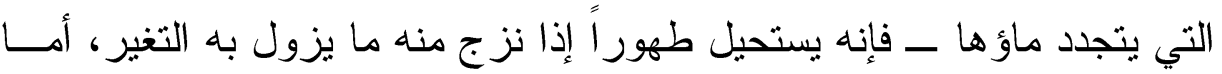

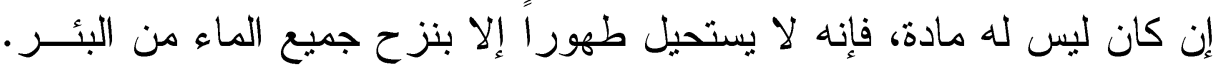

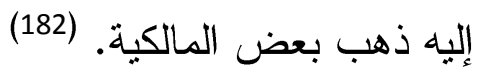

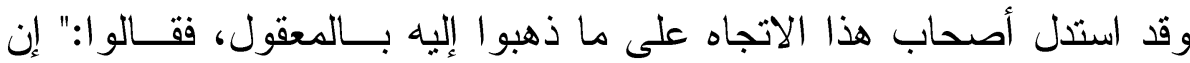
النجاسة لا تزول إلا بإضافة الماء الطهور، وليس حاصلاً ذلك بالنسبة للهــاء

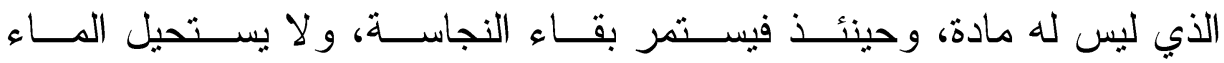
طهوراً.

( أخرجه الإمام مالك في الموطأ ــ رواية محمد بن الحسن ــ أبو اب الصــلاة، بـاب الرجـل و والمر أة يتوضآن من إناء واحد، 83/1، رقم (35).

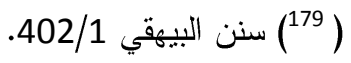

$$
\begin{aligned}
& \text { (180) (المصدر السابق. } \\
& \text { (181) المجموع 117/1، سنن البيهقي 402/1. }
\end{aligned}
$$

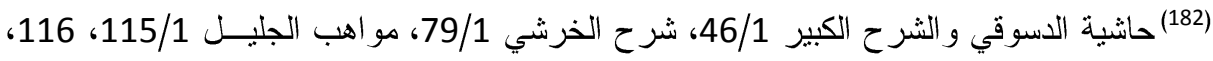

$$
\text { التاج و الإكليل 115/1. }
$$

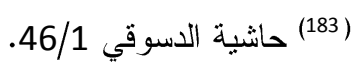


أجيب عن ذلك: بأن ما قلتموه من التفريق بين ما له مادة من المياه وما ليس

له مادة، وحصر التطهير بالمكاثزة بالماء المطلق دون غيره، كلاهما تعــوزه الدقة ويحتاج إلي " دليل..... " (184)

الاتجاه الثالث: يري أن الماء المتتجس يستحيل طاهراً بالنزح إذا زال تغيره بذلك، بشرط أن يبقي بعد النزح مقدار قلتين فأكثر، فإن بقي أقل من قلتين فلا يطهر مطلقا، سواء ز ال تغيره أم لا. إليه ذهب الشافعية (185) الحنابلة (186) بعدين

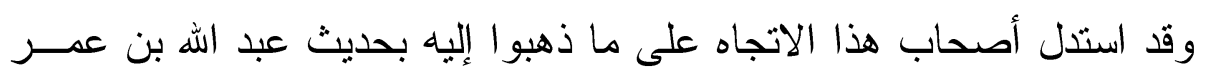

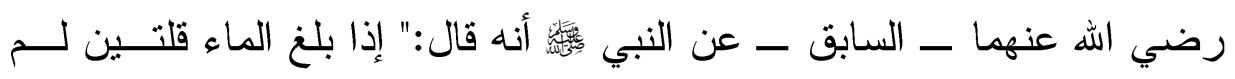
يحمل الخببث " (187).

جهة الدلامة: الحديث يدل بمفهومه على أن الماء القليل - وهو ما دون القلتين - يحمل الخبث ويتتجس مطلقا، سو اء تغير أو لم يتغير، بخلاف الكثير وهو ما

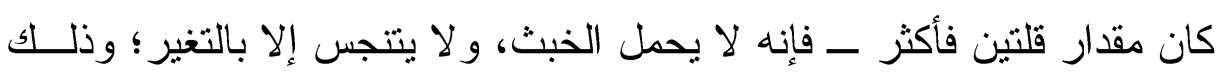

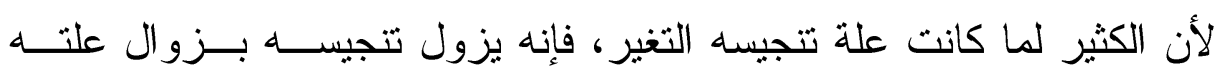

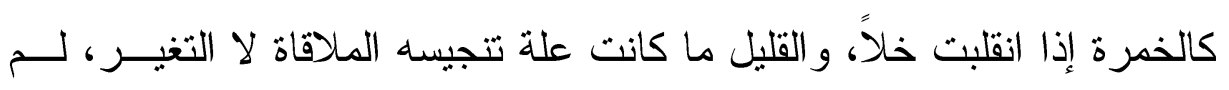
يؤثز زو ال تغيره في زو ال التتجيس(188).

(184) أحكام البيئة في الفقه الإسلامي، دكتور اه " قدمت إلى كلية الشريعة، جامعة الإمام محمد بــن

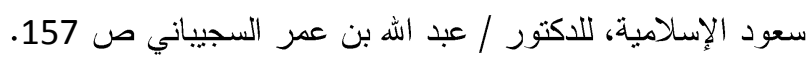

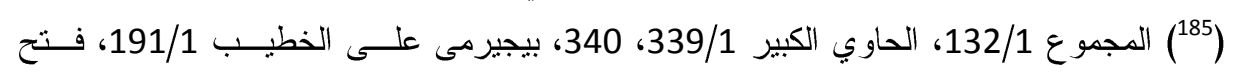

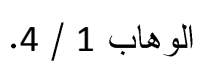

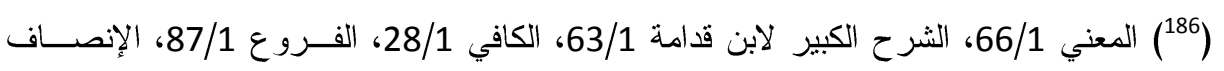

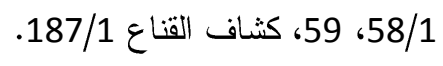

$$
\begin{array}{r}
\text { سبق تخريجه ص263 ( } \left.{ }^{187}\right) \\
\text { 66/188 } \left.{ }^{188}\right)
\end{array}
$$


يجاب عن ذلكك: بما أجاب به البحث سابقا، بأن حديث القلتين و إن كـــان قــــ

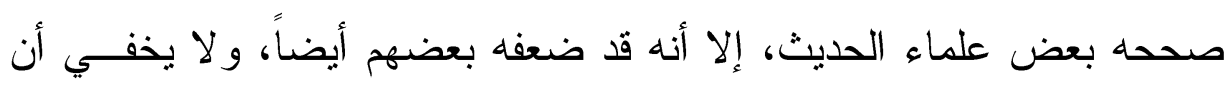

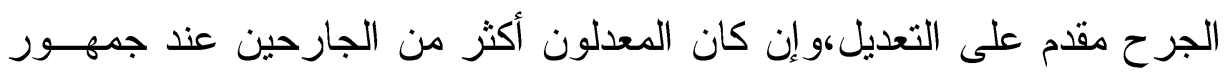

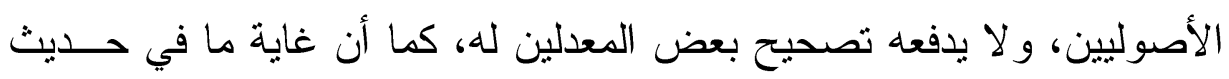

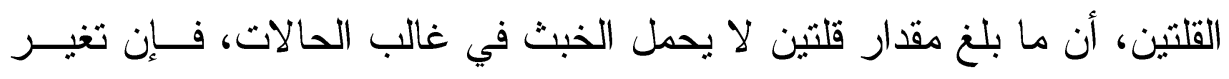

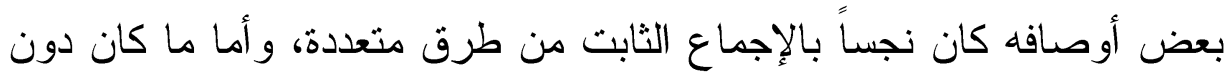

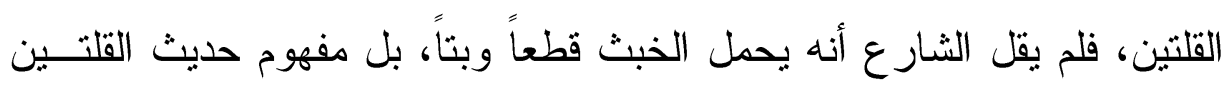

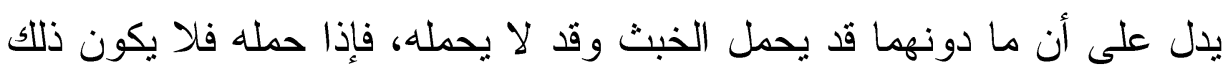

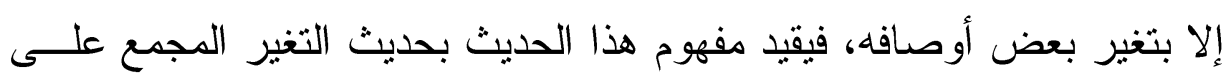

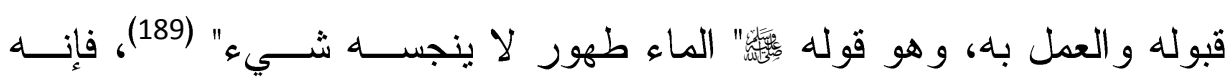

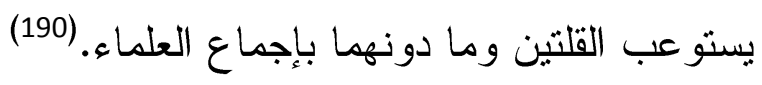

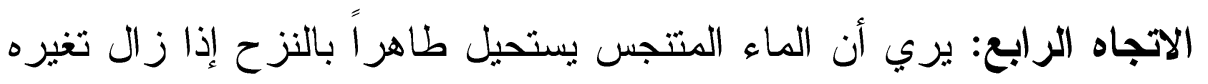

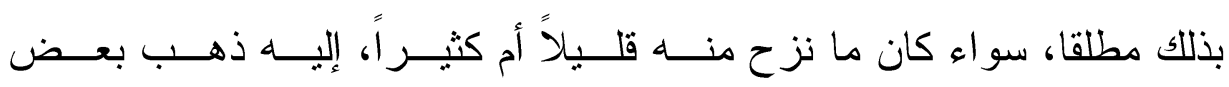

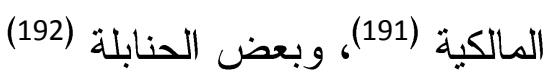
وقد استدل أصحاب هذا الاتجاه على ما ذهبو إلبه بالمعقول فقالو ا: إن الحكم

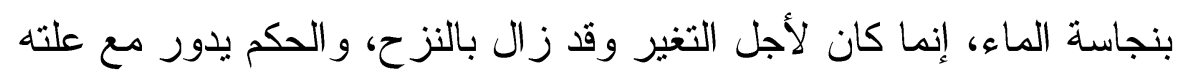

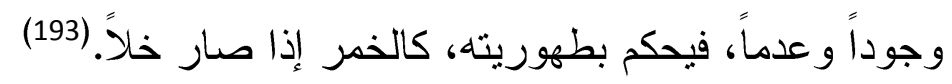

$$
\begin{aligned}
& \text { (189) سبق نخريجه ص } 261 . \\
& \text { (190) انظر ص264 من من هذا البحث. }
\end{aligned}
$$

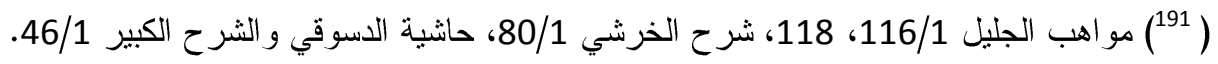

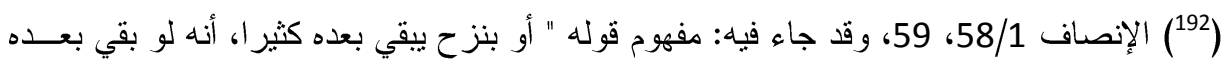

قليل أنه لا يطهر، وهو المذهب، وقيل: يطهر ".

doi: $10.12816 / 0004230$

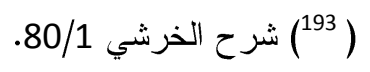




\section{الراجح:}

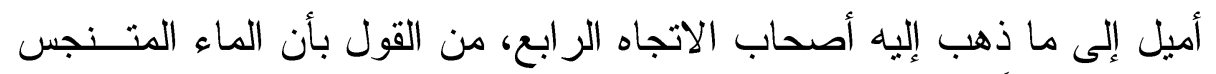

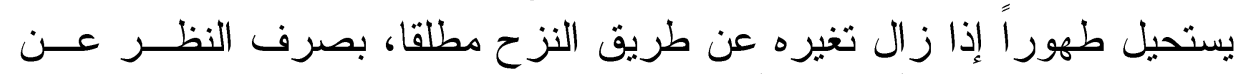

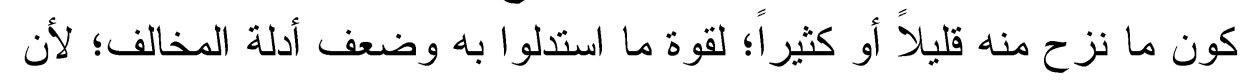

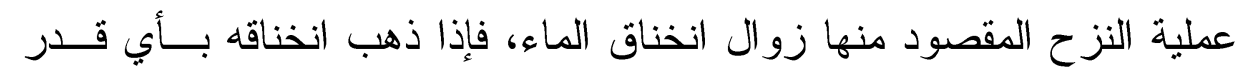
منزوح، وزال تغيره بالنجاسة، طهر لزو ال سبب التنجيس.

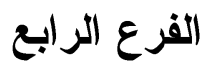

الوسيلة الرابعة: استحالة الماء النجس إلى طاهر عن طريق إضافة شيء

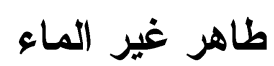

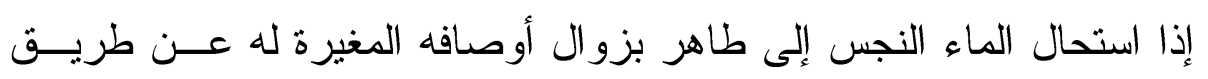

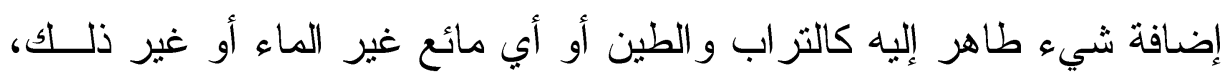

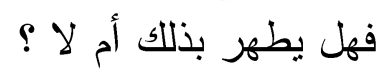

اختلف الفقهاء في هذا الثأن، وتمخض عن ذلك ظهور ثلاثة اتجاهات:

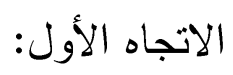

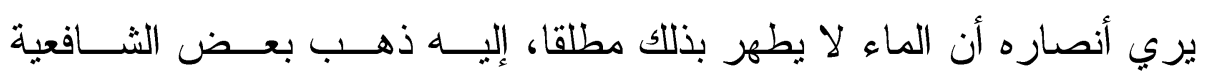

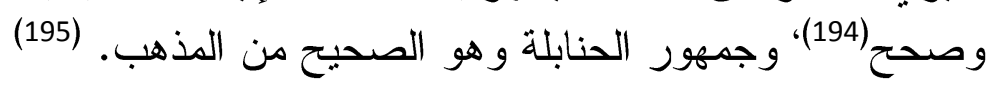

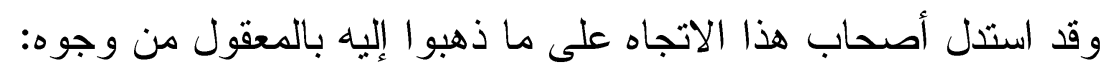

\section{الوجه الأول:}

أن المطروح فى الماء المتنجس من تراب أو غيره لا يــدفع النجاســة عــن فئس

نفسه، فعن غيره أولي. (196) فئرو الماء

( 194 المجموع 133/1، روضة الطالبين 131/1، الحاوي الكبير 339/1، المهذب 6/1، مغني

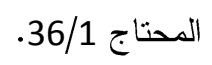

(67/1، 67/1، الشرح الكبير لابن قدامة 62/1، الإنصاف 59/1، 59/1، الفروع 88/1، الكافي

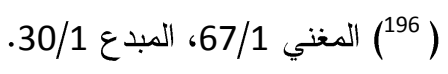




\section{الوجه الثاني:}

أن الملقي في الماء المتنجس ليس بطهور، فلا يحصل به الطهــارة كالمـــاء

\section{يجاب عن هذين الوجهين:}

بأن الماء و إن كان الأصل في التطهير، إلا أنه لا يتمتع بهذه الخاصــبة دون غيره، بل يحصل التطهير بغيره أيضاً.

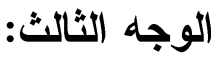

أننا لا ندري أن أوصاف النجاسة قد زالت أم غلب عليها المطروح فسترها، و إذا كان الأمر كذلك فالأصل بقاؤها. (198) يجاب عن هذا الوجه:

بأن المضاف من غبر الماء إذا حدث به زوال أوصاف الماء المتغير الثلاثة

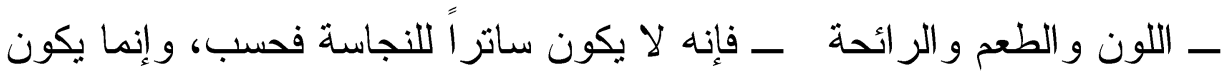
مزيلاً لها أيضا، فالمدار على التغير، كما ذكر البحث سلفاً. الاتجاه الثاني: - التان

يري أنصاره أن الماء المتنجس بطهر بما يضاف إلبه إذا كان المضاف تراباً

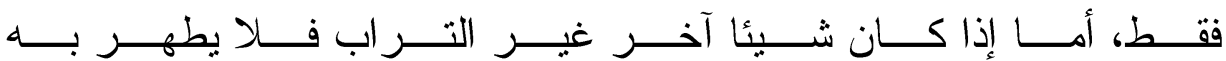
الماء، إليه ذهب بعض الثافعية.(199)، وبعض الحنابلة. (200) وقد استدل أصحاب هذا الاتجاه: على ما ذهبو ا إليه بالمعقول فقالو ا: إن التز اب لا ينفك من الماء غالبا، وهـــ قر ار له، فقد يتغير الماء دع كونه فيه، فإذاز ال التغير لحصول التزاب فيه، دل 
على استهلاك النجاسة بزو ال تغير ها، وأن التراب قد جذبها إلي نفسه حتى لـــ يقيق في الماء شيء منها. (201) أجيب عن هذا الاستدلال:بأنه لا يمكن التسليم بأن التراب له خاصـية عـن أله

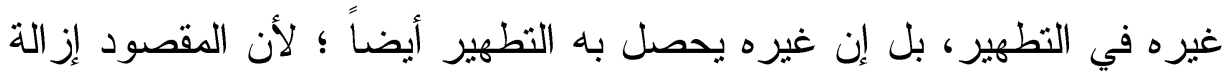

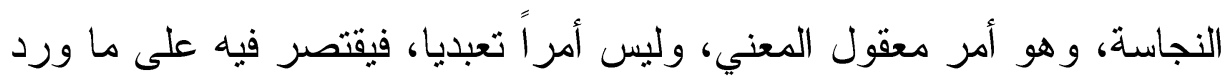
في الشرع. (202)

الاتجاه الثالث: يري أنصاره أن الماء المتتجس يطهر بما يضاف إليه من كل

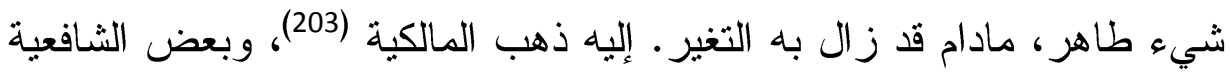

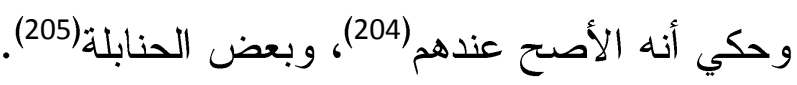
وقد استدل أصحاب هذا الاتجاه: علي ما ذهبوا إليه بالمعقول فقالوا: إن علة

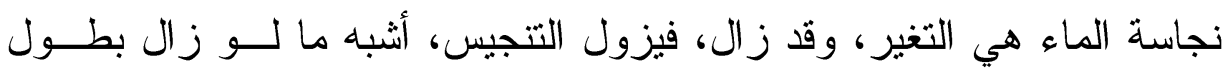

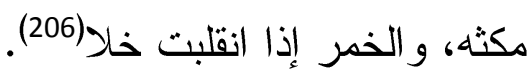

(201) الحاوي الكبير 339/1، مغني المحتاج (202/1)

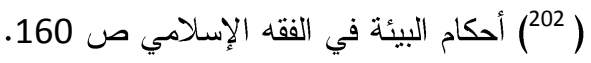

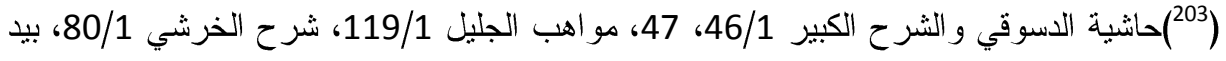

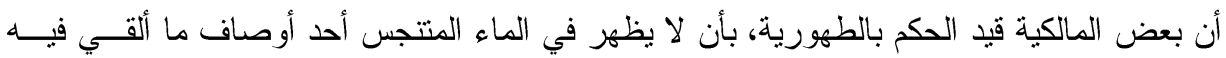

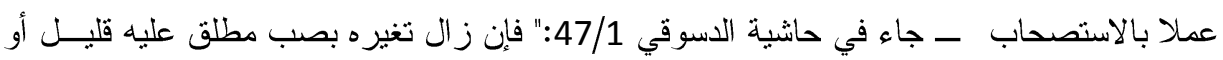

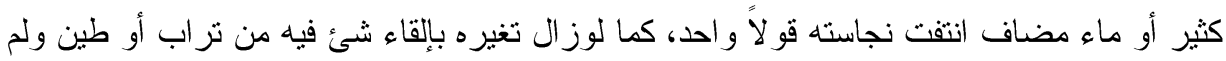

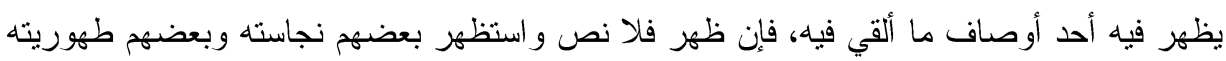

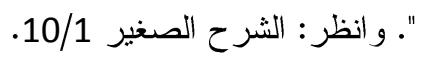

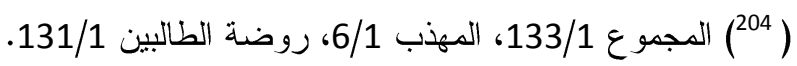

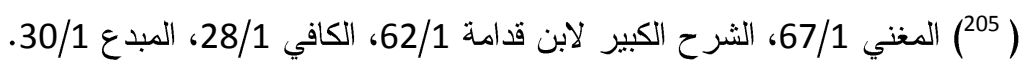

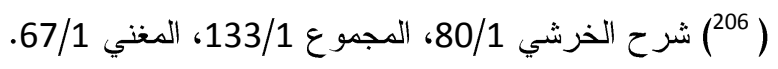


استحالة النجس إلى طاهر للانتفاع به فى الفقه الإسلاهى د.عبده السيد أحمد الثريف

الر اجح: أراني أميل إلي ما ذهب إليه أصحاب الاتجاه الثالث من القول بـأن الماء المتنجس إذا ألقي فيه شئ طاهر - جامد كالتراب و الطين أو مائع كالخل

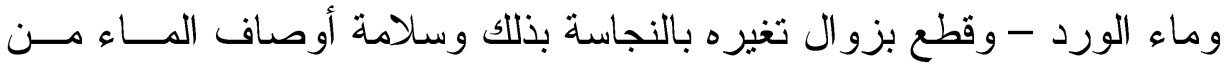
النجاسة، فإنه يكون طاهر ا، وذلك لقوة ما استدلو ا به وسلامته مــن المناقثـــة و الاعتر اض، وضعف أدلة الاتجاهين الآخرين و الرد عليهما. 


\section{المطلب الثاني}

\section{الوسائل الحديثة التي يتم بها استحالة المياه النجسة إلي طاهرة}

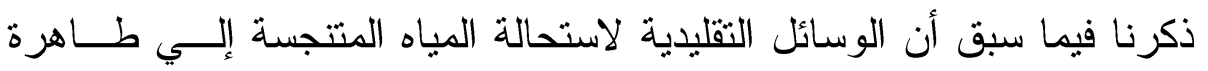

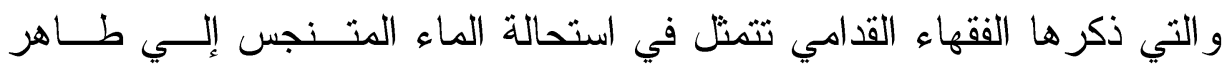

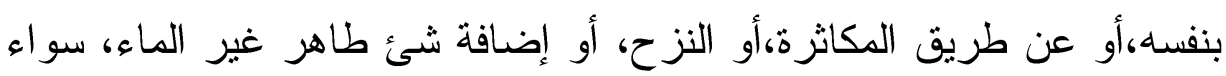

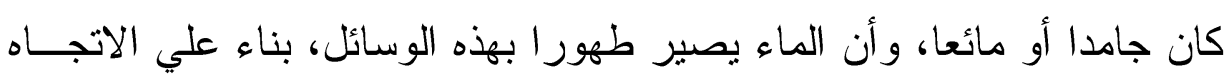
الر اجح في الفقه الإسلامي، بيد أن التقدم العلمي الذي شهدنه معظم دول العان العالم المهاء

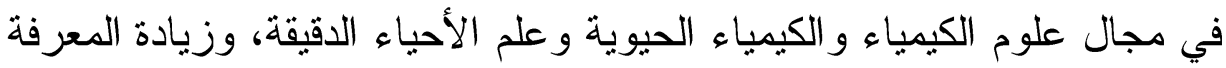

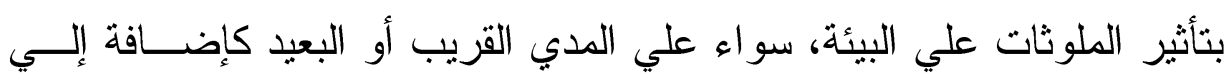

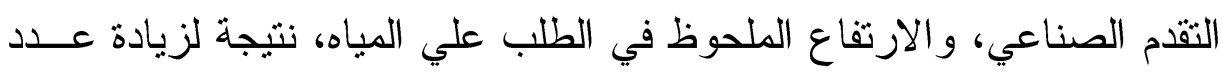

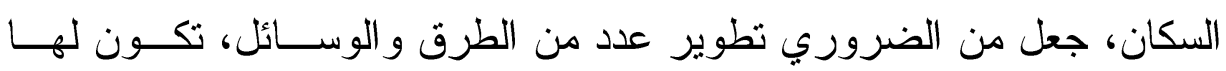

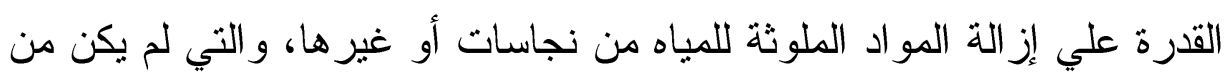
السهل إزالتها بالطرق التقليدية القديمة، لتكون ر افدا صالحا لاستعمال هذه المباه في سائر أنو اع الاستعمال.

وتتمثل المياه الملوثة في زماننا بنسبة كبيرة في مياه الصرف الصحي، الصنا،

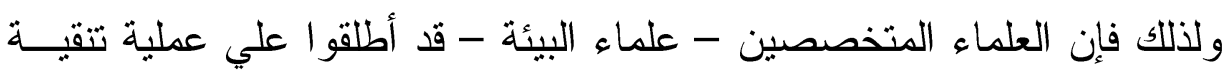
المياه الملوثة، معالجة مياه الصرف الصحي. ويقصد علماء البيئة بمعالجة المياه: عملية تنقية المياه من الثوائب و المــــواد العالقة و الملوثات و المو اد العضوية لتصبح صالحة لإعادة الاستخدام (207). 
مصادر مياه الصرف الصحي وملوثاتها:يتم تجميع مياه الصرف الصحي من عدة مصادر، وتعتمد الكميات التي يتم جمعها من تللك المصادر علي المصــدر مئر ونوعية نظام التجميع المستعمل فيها. ومن مصادر تلك المياه ما يلي:

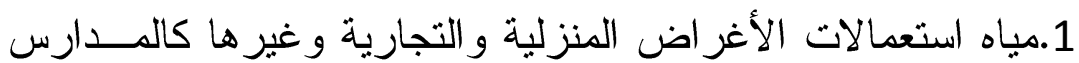

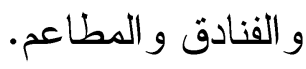

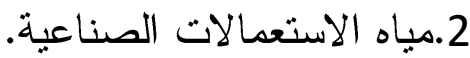
3.مياه الأمطار في حالة دمج شبكة المجاري بشبكة تصريف السيول. 4.المياه المتسربة من عدة عناصر صلبة وذائبة، يمثل الماء فيها نسبة 99.9\%، و البقية عبارة عن ملوثات أهمها:

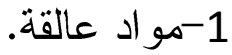
2 - مو اد عضوية قابلة للتحلل. 3 ـ كائنات حية مسببة للأمر اض. 4- مو اد مغذية للبنات، نتزوجين، فوسفور ، بوتاسيوم. 5 ـــ مو اد عضوية مقاومة للتحلل. 6 7

\section{طرق معالجة المياه عند علماء البيئة:}

تشتمل عملية معالجة مياه الصرف الصحي علـي عـــدة مر احسلـل فيزيائيــة وكيماوية وبيولوجية، لتصبح صالحة لإعادة الاستخدام، بيد أن درجة المعالجة مباه لهذه المياه، تتحدد حسب نوعية الاستخدام، فإذا كان الاستخدام آدميا، فإن درجة 
التنقية تكون عالية، بعكس ما إذا كانت المياه سنستعمل في المجال الزراعي أو الصناعي (209).

وتتمنل عملية معالجة المياه لاي علماء البيئة في المر احل الآتية: المرحلة الأولي: المعالجة التمهيدية أو الميكانيكية: تتمنل المعالجة في هذه المرحلة علي فصل وتقطيع الأجز اء الكبيرة الموجودة

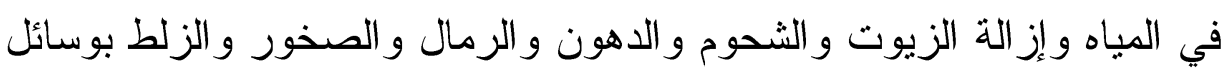

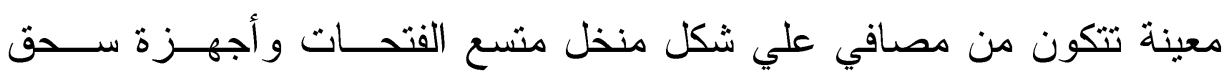

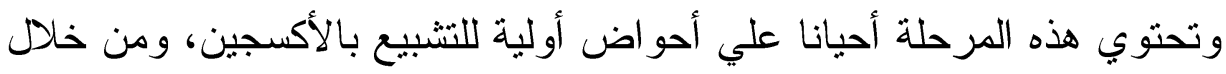

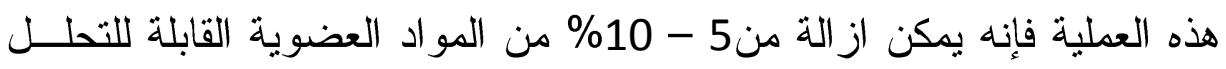
إضـافة إلي2 - 20\% من المواد العالقة، ولا تعد هذه النسب من الإز الة كافيـــة لغرض استعمال المباه في أي نشاط. المرحلة الثانية: المعالجة الأولية:

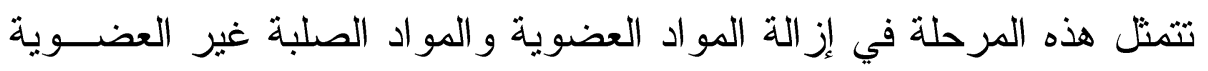

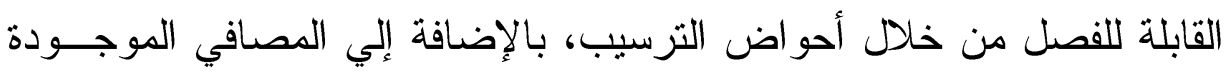

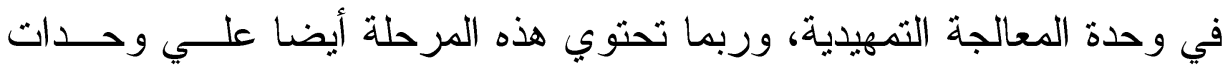

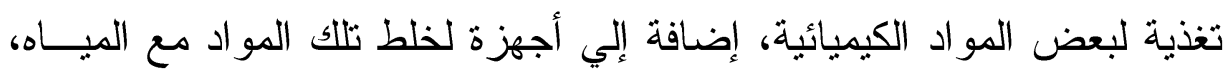

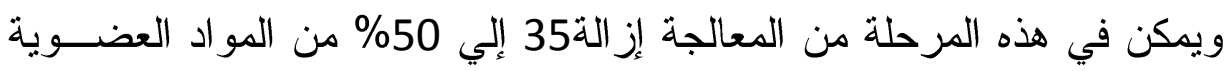

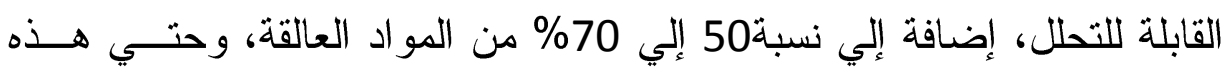
الدرجة من المعالجة، فإن الماء لا يز ال غير صالح للئه للاستعمال.

(209) المرجع السابق، استعمال مياه الصرف الصحي المعالجة للأغر اض الزر اعيـة، د. عبـــــ الله السليمان محمد الحديثي ص 11. 


\section{المرحلة الثالثة: المعالجة الثانوية:}

وتتمثل هذه المرحلة في استحالة المياه المعالجة من خلال المرحلتين السابقتين

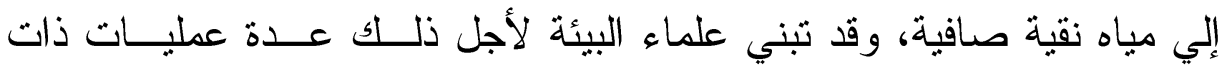

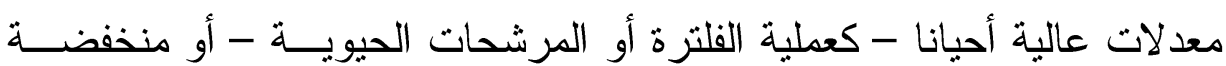
أحيانا أخري، كالمعالجة بالعو امل الطبيعية مثل الرياح و الأمطــار و الحـــرارة

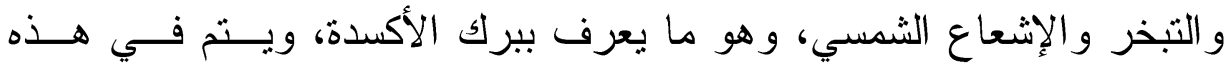

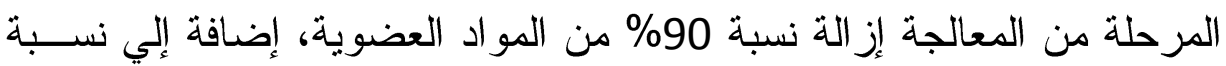
\% \% من المو اد العالقة.

\section{المرحلة الر ابعة: المعالجة المثقدمة: لهاءة}

يتم تطبيق هذه المرحلة من المعالجة، عندما تكون هناك حاجة إلي ماء نقـي

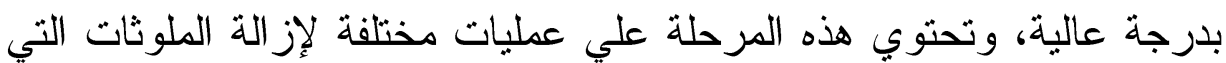
لا يمكن إز التها بالطرق السابقة، وتتضمن هذه العمليات ما يلي:

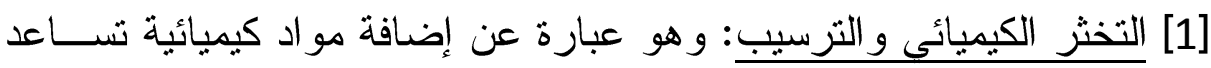

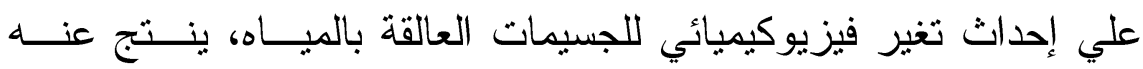

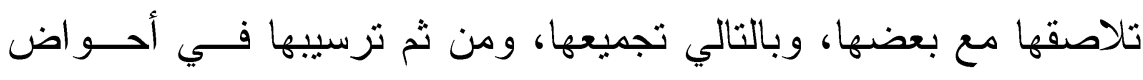
الترسيب نظر الزيادة حجمها.

[2] الترشيح الرملي: وهو عبارة عن عملية تسمح بنفاذ الماء خــلال وسـطـ رملي بسماكة لا تقل عن 50 سم، ويتم من خلال هذه العملية إز الة معظم

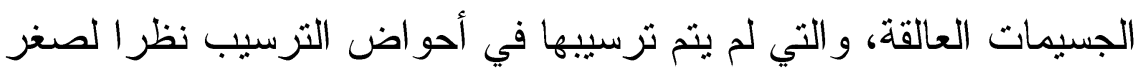

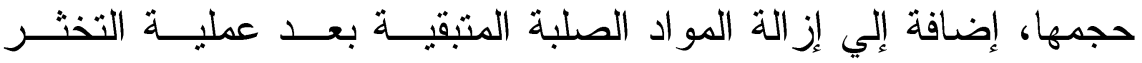
الكيميائي.

[3] الامتصاص الكربوني: ويتم في هذه العملية استخدام كربون منشط لإز الة المواد العضوية المذابة، حيث يتم تمرير المياه من خلال خز انات تحتوي

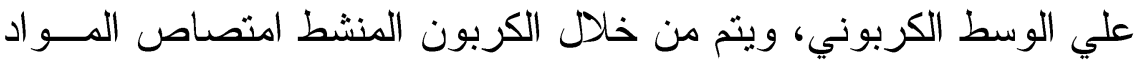


العضوية المذابة الموجودة في مياه الفضلات، وبعد تشبع الوسط الكربوني ألتي يتم إعادة تنشيطه بو اسطة الحرق أو استخدام مو اد كيميائية.

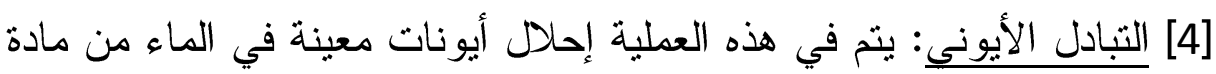

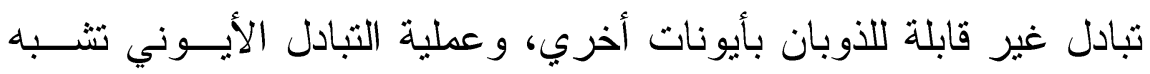

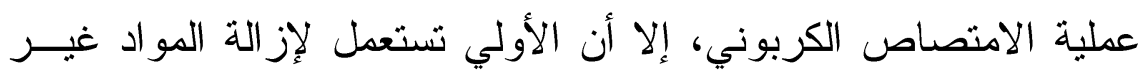
العضوية.

[5] التتاضح العكسي: يتم في هذه العملية ضخ الماء تحت ضغط عــال مــن

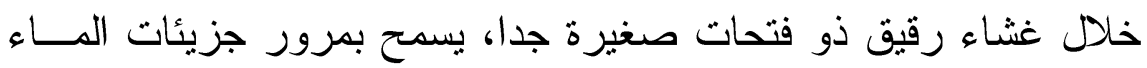
فقط، ويمنع مرور جزيئات الأملاح. المرحلة الخامسة: التطهير: يتم في هذه المرحلة قتل جميع الكائنات الحية الدقيقة المسببة للأكر اض بعدة وسائل من أهها: الحرارة والتشخين أو الأشعة فوق البنفسجية، أو حقن محلول الكلور إلي حوض التطهير بجرعات لا تضر بالإنسان أو الحيوان، حتي يــنت التأكد من سلامة المياه من الجر اثثم (210).

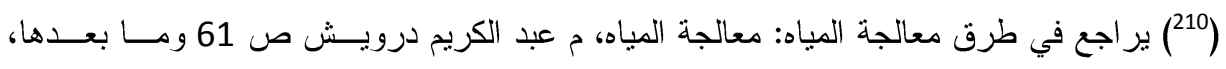

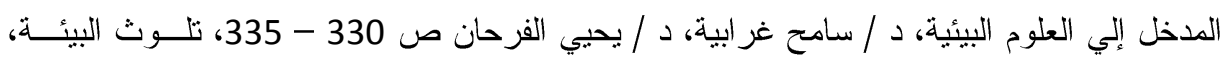

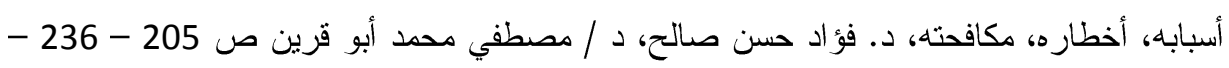

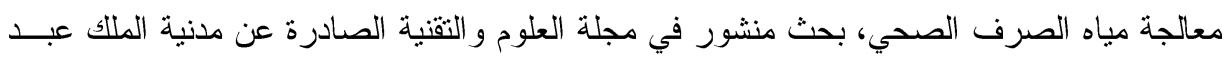

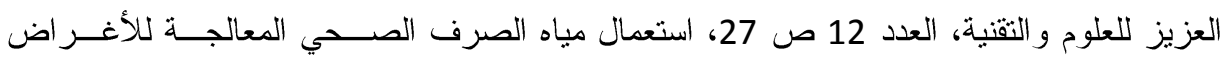

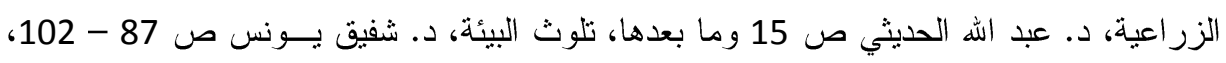

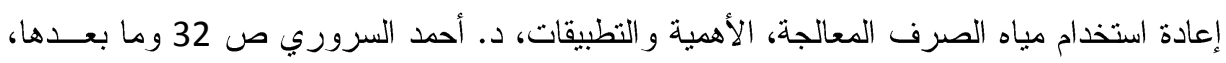
المو ارد المائية غبر التقليدية في الوطن العربي، م علي مبدي اللبدي ص 62 وما بعدها. 


\section{المطاب الثالث}

\section{أوجه الاتتفاع بالمياه النجسة المستحالة إلي طاهرة}

\section{بالطرق الحديثة في منظور الفقه الإسلامي}

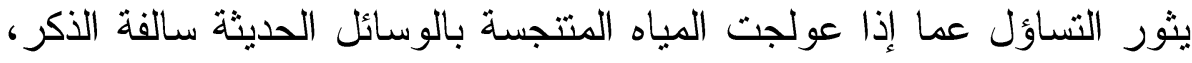

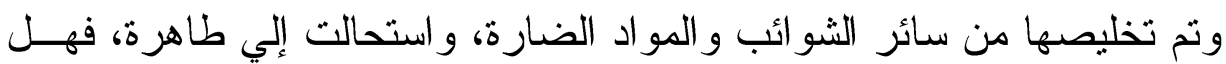
يجوز الانتفاع بها أم لا بن باتِ

للإجابة علي هذا التساؤل، ينبغي التفرقة بين ما إذا كانت هذه المياه المعالجة

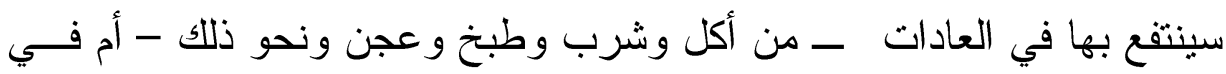

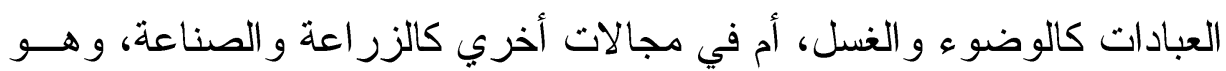
ما سيعرض له البحث من خلال النقاط التالية:

[أ] الاتتفاع بالمياه المستحالة إلي طاهرة بالطرق الحديثة في العادات:

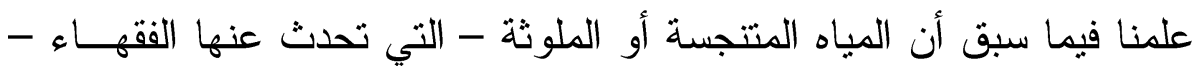
تتمثل في زماننا بنسبة كبيرة في مياه الصرف الصحي، إذ إنها عبارة عن ماء

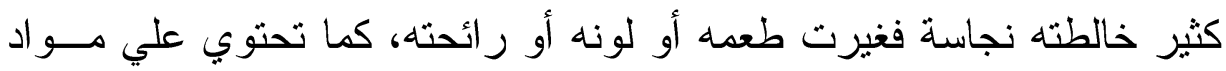

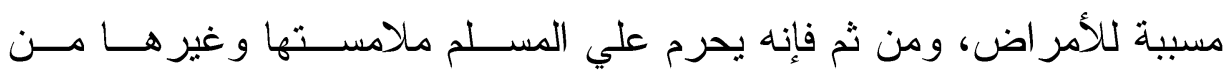

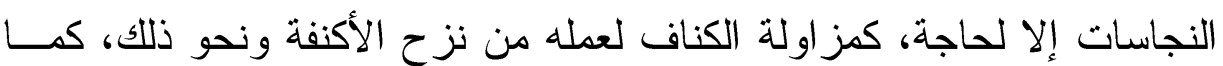

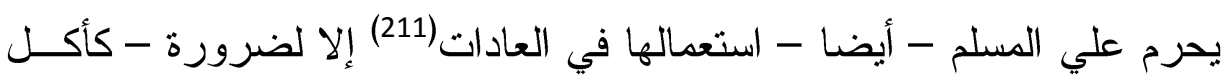
الميتة للمضطر وشرب الخمر لإز الة غصة - و هي تقدر بقدر ها(212). كما لا يجوز استعمال هذه المياه في العبادات كالوضوء و الغسل، وقد حكيـي

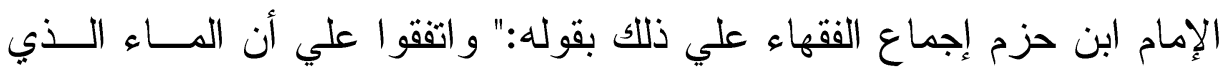

(121) كتب ورسائل وفتاوي ابن تيمية 16/21، وقد جاء فيها: " كل نجس محرم الأكل ".

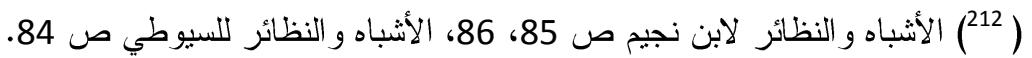
doi: 10.12816/0004230 
حلت فيه نجاسة، فأحالت لونه أو طعمه، فإن شربه لغير ضرورة و الطهـارة

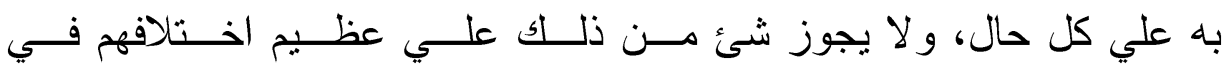
النجاسات" (213). فإذا ما استحالت هذه المياه المتنجسة أو الملوثة بالطرق الحديثـة - ســالفة الذكر - إلي طاهرة، فهل يجوز استعمالها في العادات أم لا ؟

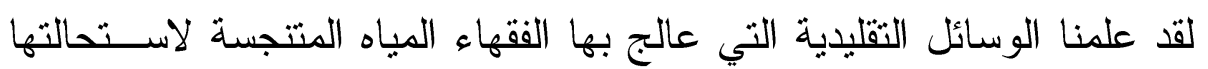

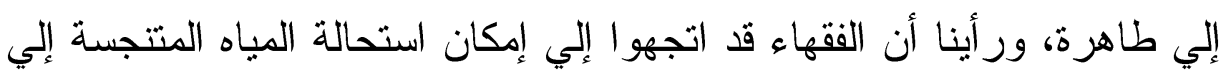
طاهرة عن طريق المكاثرة بالماء الطهور (214).

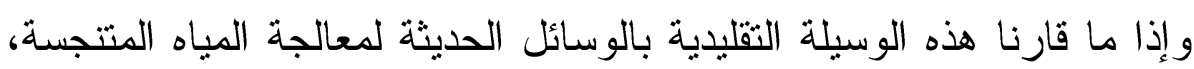

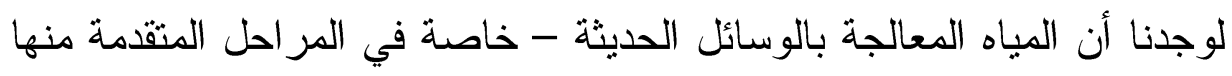
- أجدر بالحكم بالطهارة من المعالجة بالمكاثرة كوسيلة تقلبديــة ؛ لأن الميــاه

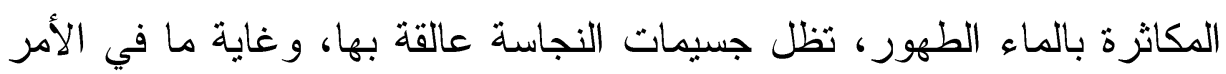
أنها تختفي - فقط - بسبب كثرة الماء(215). بالماء لطهات أما الوسائل الحديثة - خاصة في مر احلها المتقدمة - فإنه يتت معهــــا إز الـــة جميع الجسيمات النجسة العالقة بالماء، بحيث لا يكون لها وجود علئ الئه الإطلاق.

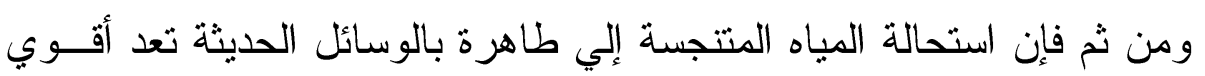

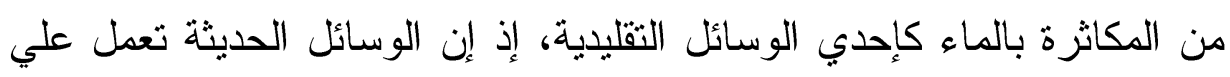

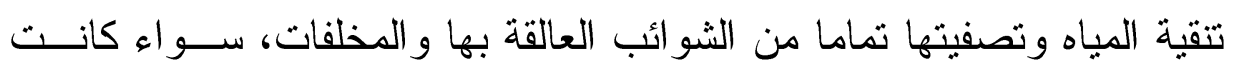

$$
\begin{aligned}
& \text { (19) } 19 \text { مر اتب الإجماع لابن حزم صن } 19 .
\end{aligned}
$$

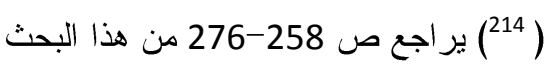

$$
\begin{aligned}
& \text { (215) أحكام البيئة في الفقه الإسلامي ص } 170 .
\end{aligned}
$$


طاهرة أم نجسة، بحيث تبدوا وكأنها لا فرق بينها وبين ما نزل من السماء أو

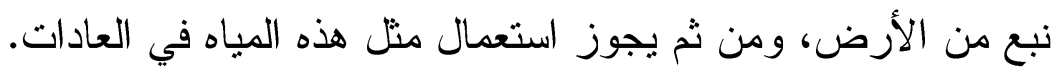

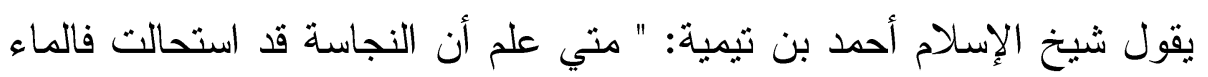

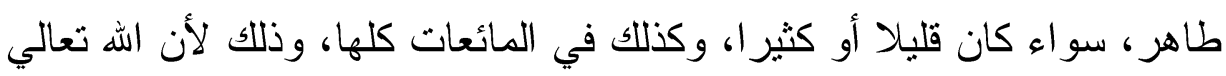

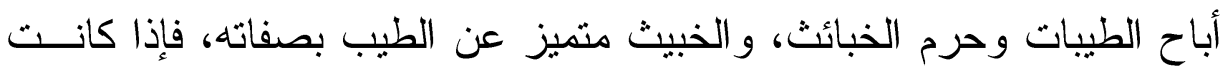
صفات الماء وغيره صفات الطيب دون الخبيث، وجب دخوله في الحلا دون ونير ون

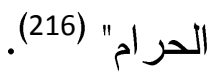

وقد علمنا فيما سبق - أيضـا - أن بعض الفقهاء قد ذهبـــوا إلــي أن الميــاه المتتجسة تستحيل طاهرة عن طريق إضافة شئ طاهر غير الماء إليها كالتراب و الطين ونحو ذلك، حتي ولو ترتب علي ذلك تغير لون الماء(217).

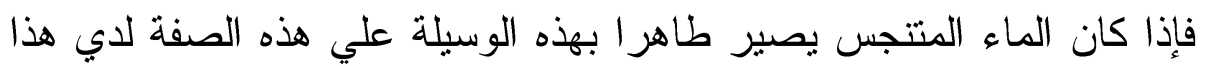

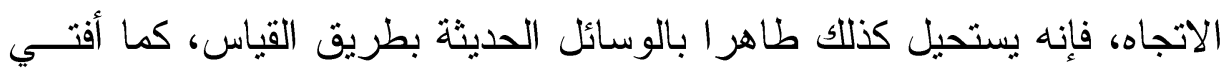

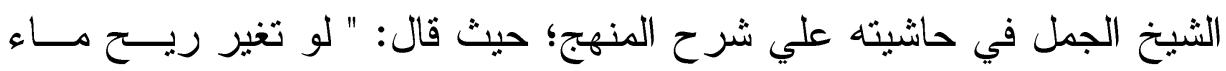

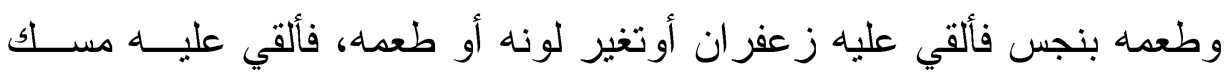
فز ال تغيره طهر ، وقس علي ذلك " (218). فقوله: " وقس علي ذلك " أي: أجر هذه الطريقة في التطهير بأي سائل له قوة

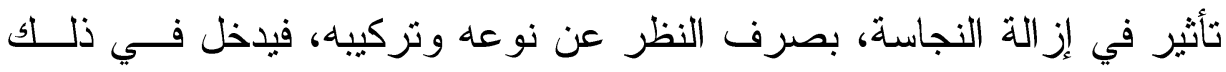

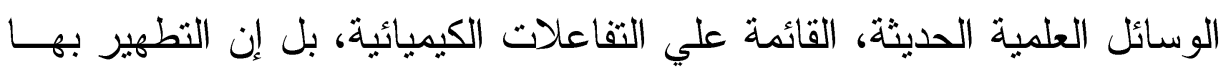

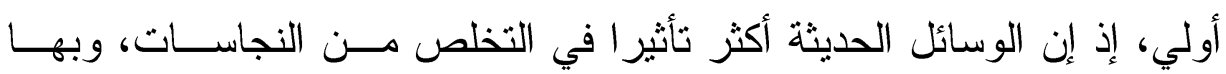

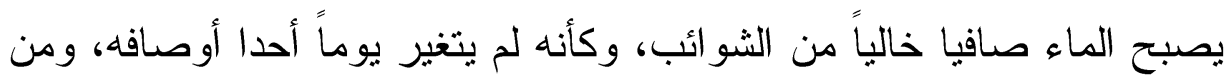

(32/21 (216) كتب ورسائل وفتاوي ابن تيمية (217) ير اجع ص 274 ، 365من هذا البحث.

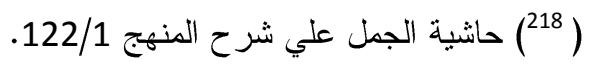


ثم يجوز استعمال مثل هذه المياه في العادات من أكل أو شــرب أو طــبخ أو عجن أو نحو ذلك.

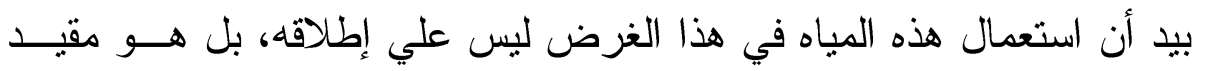

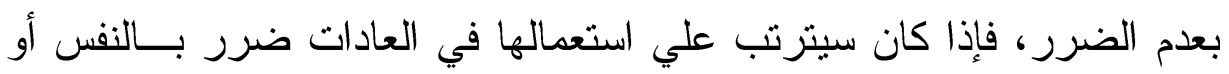

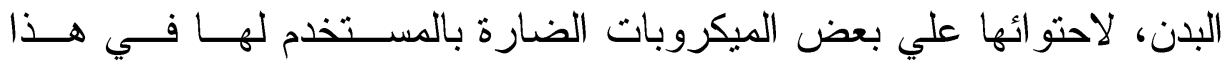

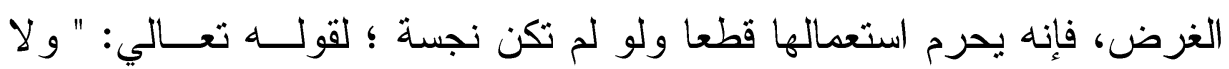

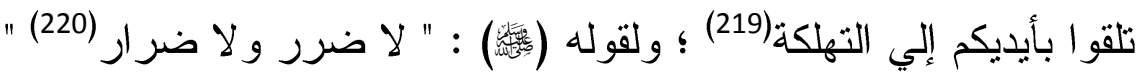
هذا: ولما كانت هذه المياه، مما تتفر منه الطباع، وتستقذره النفــوس، فإنـــهـ يستحسن الاستغناء عنها، متي وجد غيرها من المياه الباقية علي أصل خلقتها، احتياطا للصحة و اتقاء للضرر، و هذا ما نادي به كبار العلماء بالمملكة العربية

(195) (195).

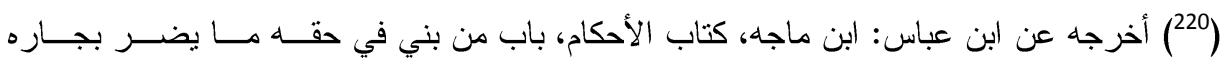

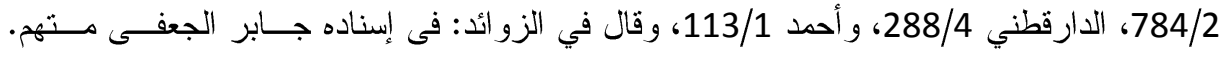

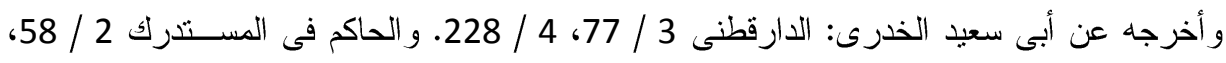

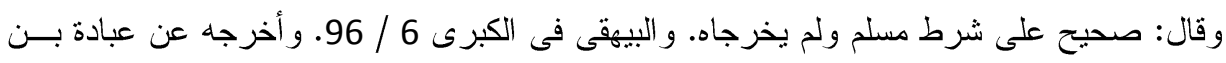

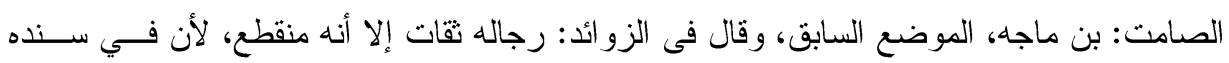

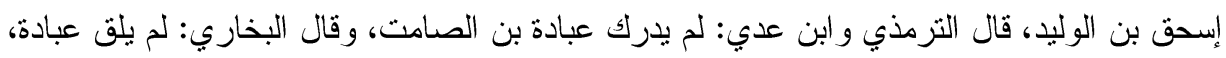

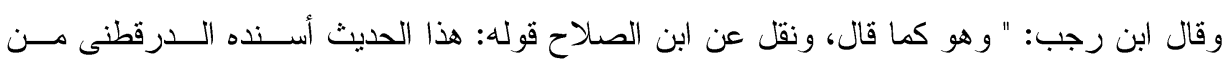

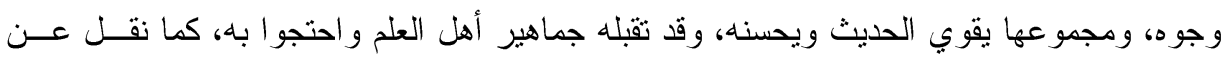

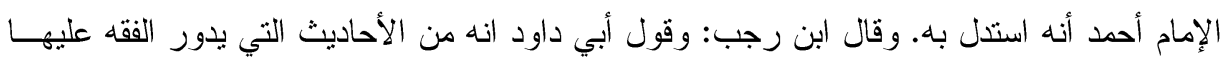
283

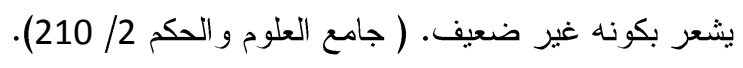


السعودية، عندما أفتو الجواز الاستفادة من المباه المعالجة بالوسائل الحديثة في العادات و العبادات(221).

\section{[ب] الانتفاع بالمياه المستحالة إلي طاهرة بالطرق الحديثة في العبادات:}

علمنا فيما سبق أن الوسائل الحديثة لاستحالة المياه المتتجسة إلي طاهرة أكثر تأثير ا في التخلص من النجاسات من الوسائل التقلبدية التي تحــدث عنها الفقهاء، حيث تصير بها المياه صافية خالية من أي شائبة، كالمباه الباقية علي أصل خلقتها. وقد تبين للبحث صلاحية هذه المباه للانتفاع بها في العادات بضو ابط معينة. ومن ثم فإنه يجوز الانتفاع بها - أيضا - في العبادات، فيجوز استعمال هذه المباه في رفع الحدث بنوعيه - الأصغر و الأكبر - وحكم الخبث، لأنـــه مـــاء طهور، بل قد يكون استخدام هذه المباه في العبادات أخف منـــهـ فــي مجـــال العادات ؛ لأن النفوس تتفر من استعمال هذه المياه في العادات دون العبادات. بيد أنه يجب علي المسلم أن يحتاط لنفسه عند استخدامه لهذه المباه في مجال العبادات، لأنه يتوقف علي طهورية هذه المياه صحة طهارته، وبالتالي صــحة عبادته التي تثوقف صحتها علي الطهارة.

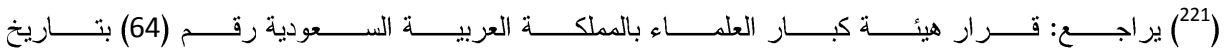

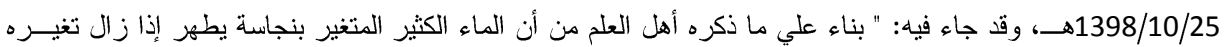

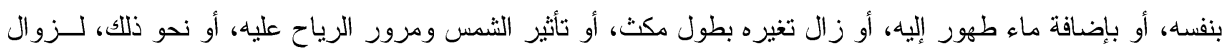

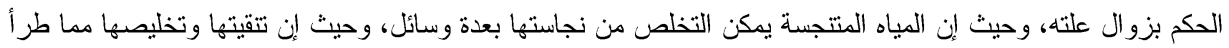

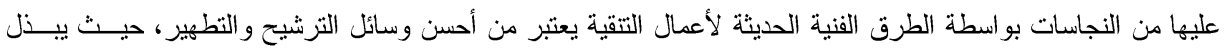

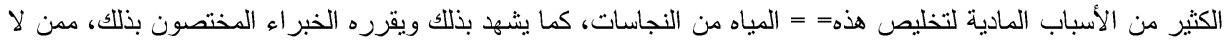

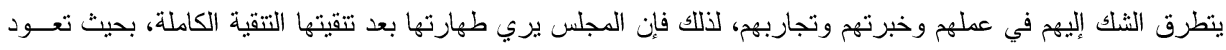

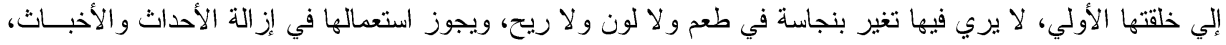

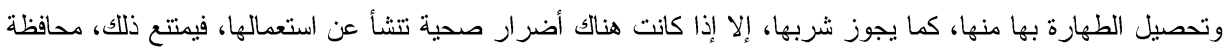

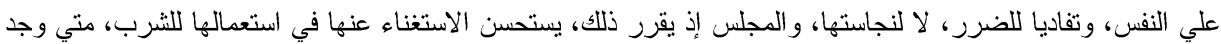
إلي ذلك سبيلا، احتياطا للصحة، و اتقاء للضرر، وتنزها عما تستقزره النفوس، وتنفر منه الطباع 11. doi: $10.12816 / 0004230$ 


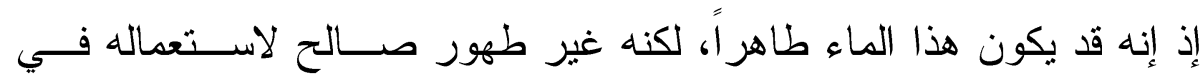

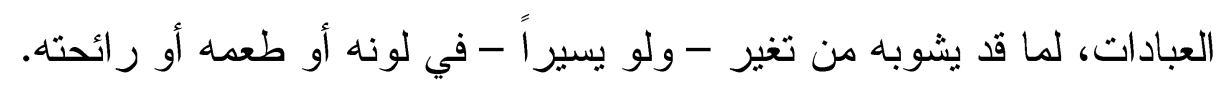

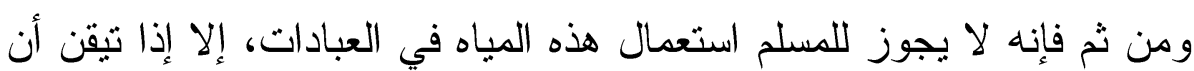

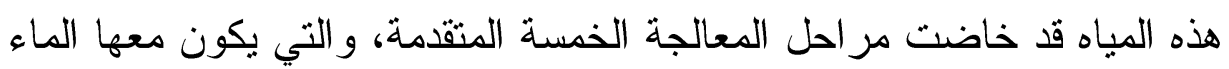
صافياً، كأنه باق علي أصل خلقته، لم يتغير أحد أوصافه.

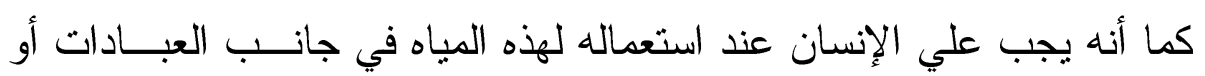
التحسينيات (النظافة) أن يكون علي يقين تام من صلاحية هذه المياه للاستعمال

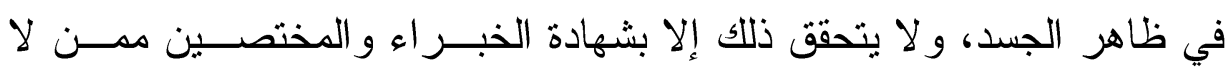

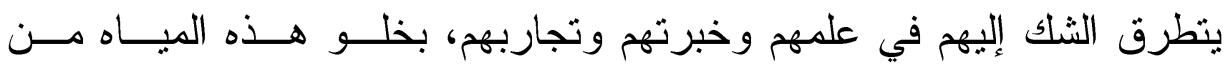

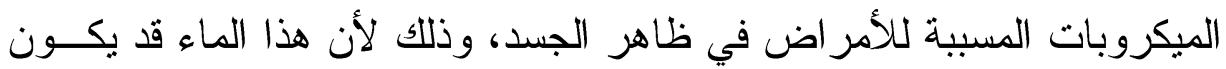
طهور ا، لكنه يترتب علي استعماله في ظاهر الجسد ضرر به، نظر الاحتو ائه

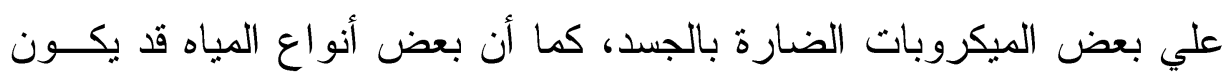

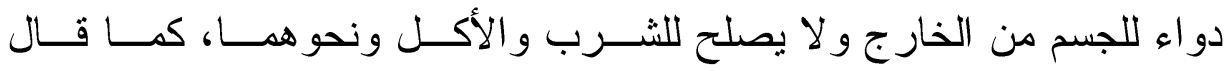
الفقهاء (222).

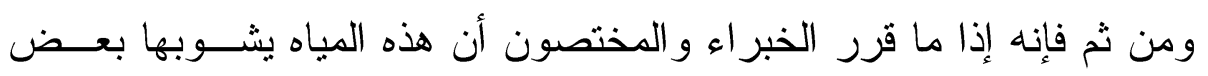

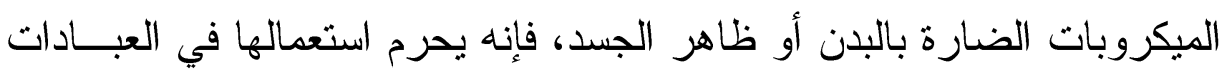

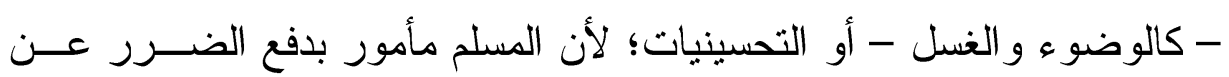

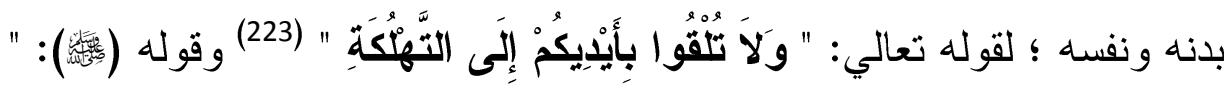

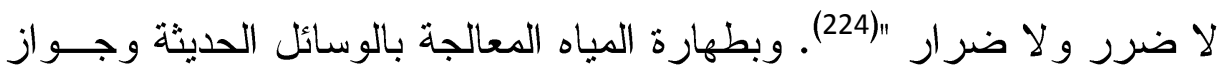


استعمالها في مجال العبادات، صدرت الفتوي من هيئة كبار العلماء بالمملكــة

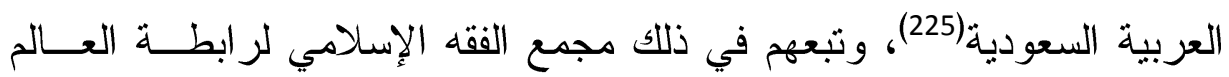
الإسلامي (226).

[ ] الاتتفاع بالمياه المستحالة إلي طاهرة بالطرق الحديثة فـــ مجــال الزراعــة

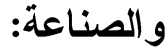

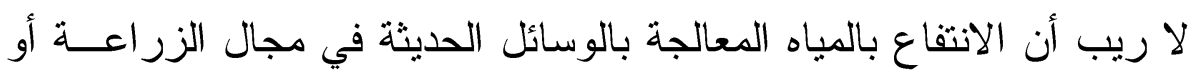
الصناعة أخف منه في مجال العبادات أو العادات، إذ إن استخدام هذه المياه في

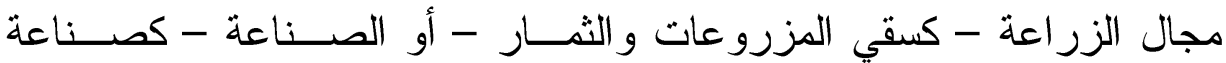
الأسمدة - من الأمور المقبولة في كثير من المجتمعات، كما أن الحاجـــة إلــي المياه المعالجة لاستخدامها لأغر اض الزر اعة أو الصناعة أكثر من الحاجة إليها

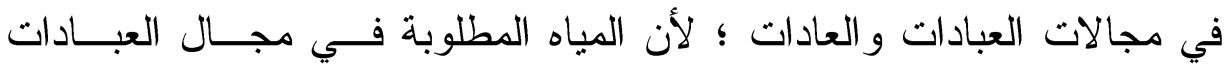
و العادات أقل بكثير من المياه المحتاج إليها في مجال الزر اعة و الصناعة(227).

(225) سبق ذكر نص هذه الفتوب هامش ص 285 ، 286 ص66، 67 من هذا البحث.

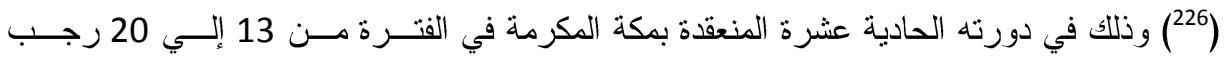

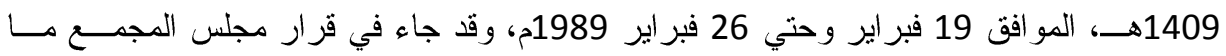

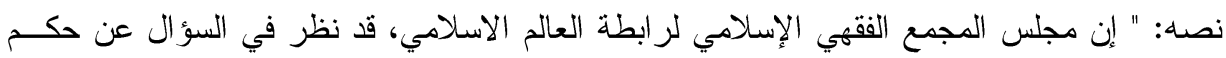

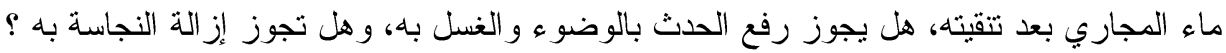

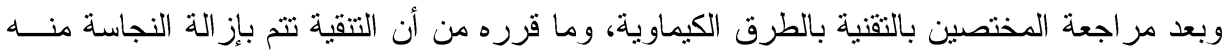

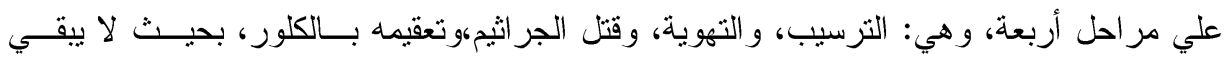

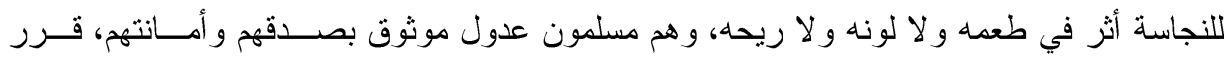

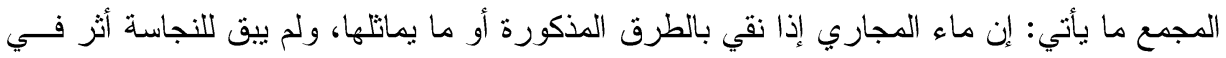

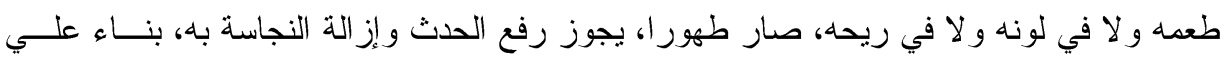

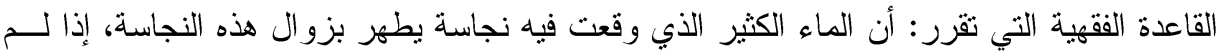

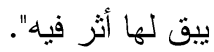
(287) معالجة مياه الصرف الصدي، بحث منشور في مجلة العلوم و التقنية عدد 12صاص30. doi: 10.12816/0004230 
ولهذا نجد كثير ا من دول العالم ذات الموارد المحــدودة للميـــاه تلجــأ إلــي استعمال المياه المعالجة في مجال الزر اعة والصناعة، بل إن بعض دول هذه الدابل الدول لجأت إلي استخدام مباه الصرف الصحي دون معالجة(228. و السؤال الذي يطرح نفسه: هل يجوز شرعا استخدام المياه المعالجة بالوسائل دئل داه

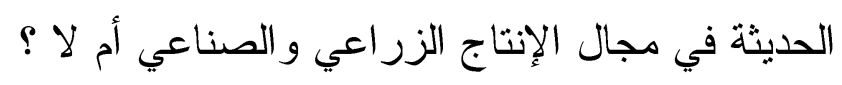

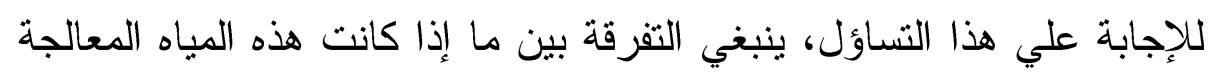

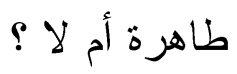

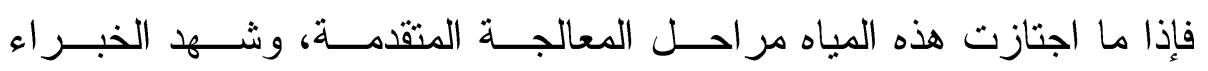

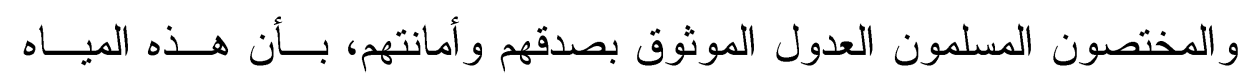

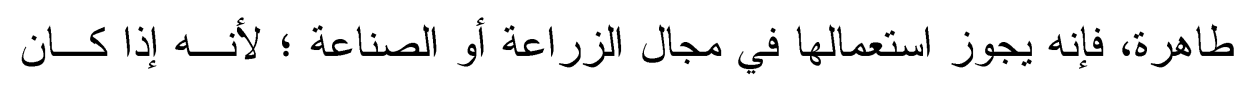

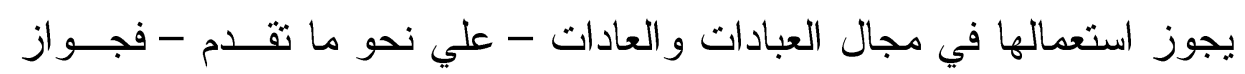

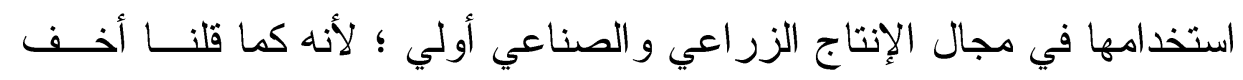
بكثير من الاستخدام في مجال العبادات و العادات.

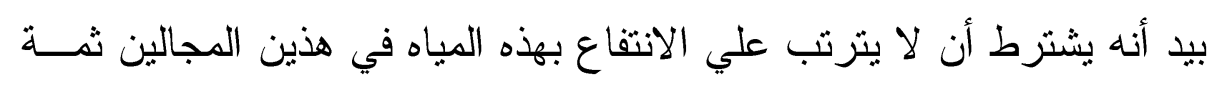

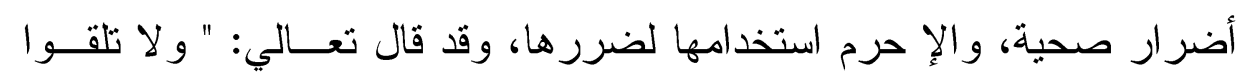

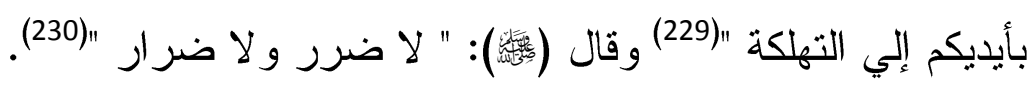

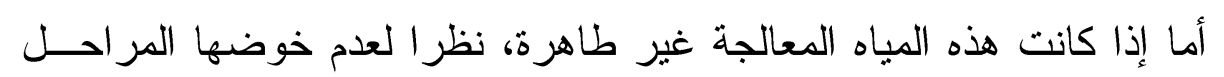

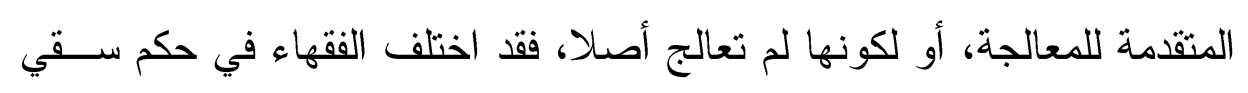

$$
\begin{aligned}
& \text { (228) المو ارد المائية غير النقليدية في الوطن العربي ص } 8 . \\
& \text { (229) سورة البقرة، بعض الآية (195). }
\end{aligned}
$$

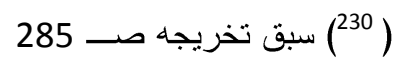


الزروع و الثمار بها أو تسميدها بما تحتويه من فضلات وعذرة الناس، وتبلور

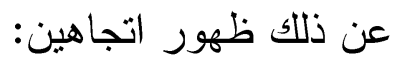

\section{الاتجاه الأول:}

يري أنصاره أنه يجوز سقي الأرض الزراعية وتسميدها بالنجاسـات، وأن

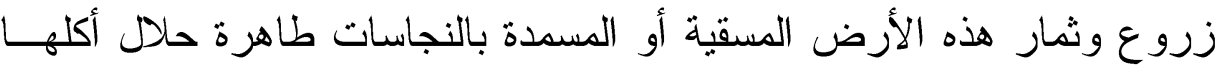

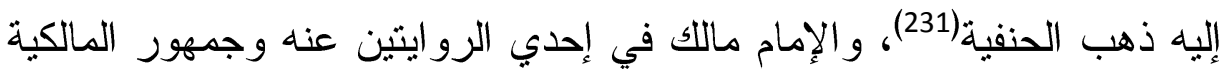

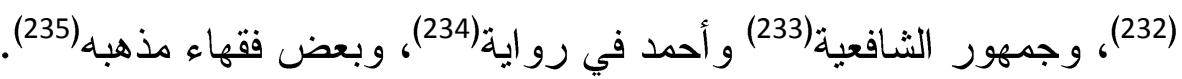
وقد استـل أصحاب هذا الاتجاه علي ما ذهبو ا إلبه بأدلة من الســــة و الأثــر

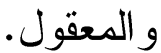

341/6 حاشية ابن عابدين

(232) الذخيرة 188/ 188، التاج و الإكليل 138/1 حيث جاء فيه: " الماء النجس يسقي بـ شجر أو بقل فالتثر و البقل طاهرتان... " و انظر أيضا: مو اهب الجليل 138/1، حاشية الدسوقي و الثرح حالكبيـر

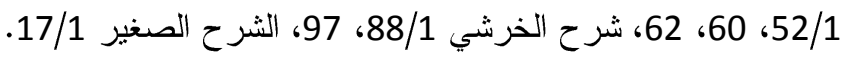

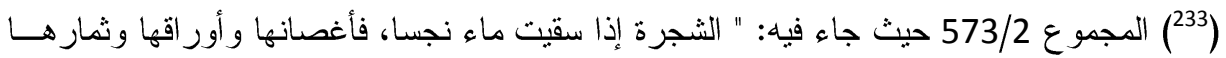

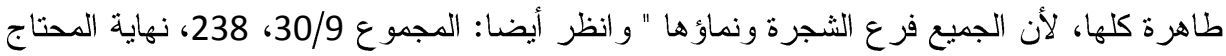

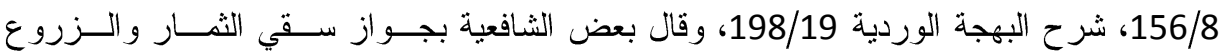

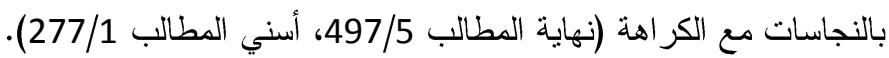

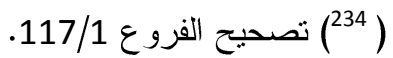

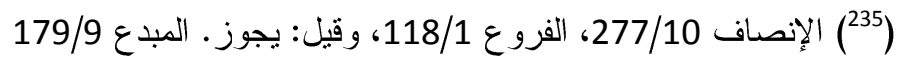

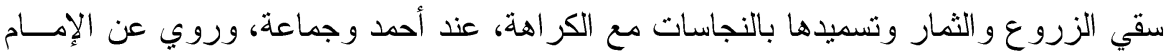

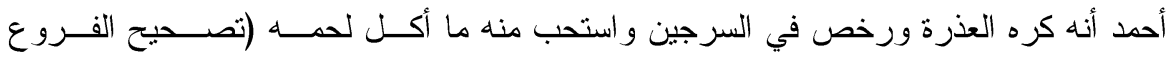
117/1، الفروع 378/10، المبدع 177/9). 


\section{أما (السنة:}

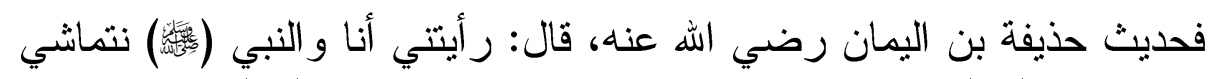

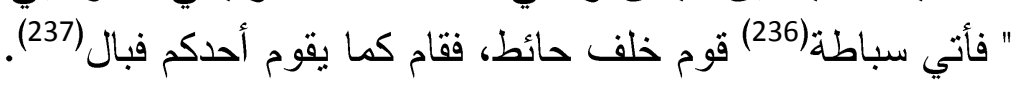

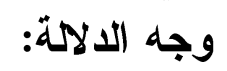

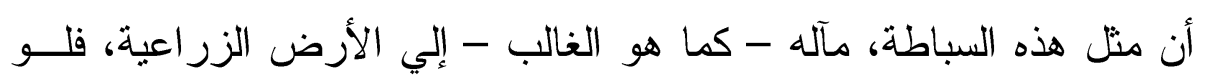

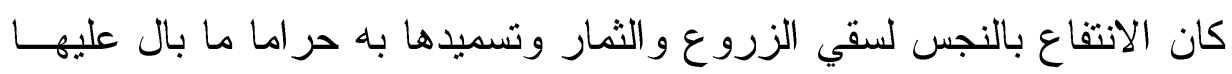

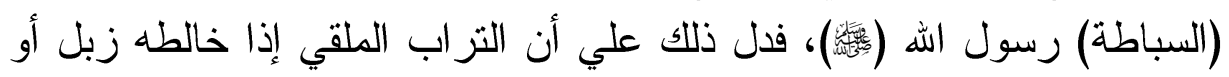

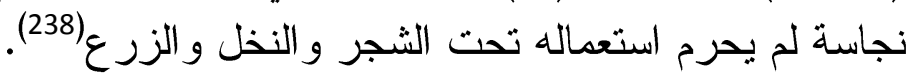

\section{وأما الأثر:}

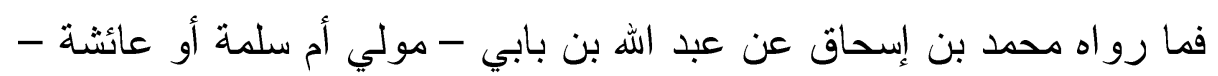

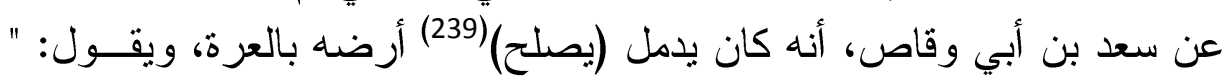
مكتل عرة مكتل بر "(240).

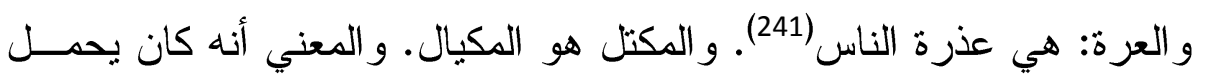
مكيالا من عذرة الناس، ليصلح أو يسمد به أرضده (242).

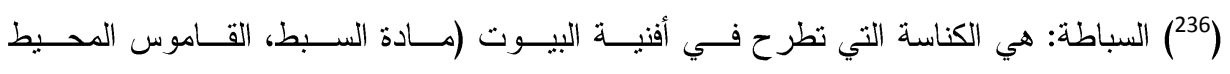
. (361/2 (237) متفق عليه و اللفظ المسلم (أخرجه البخاري، كتاب الوضو ء، باب البول عند صاحبه والتشـتر

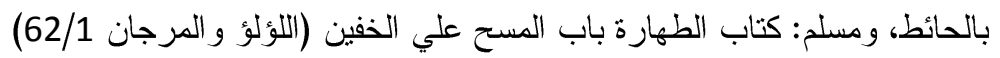

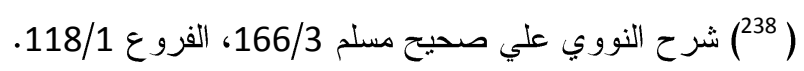

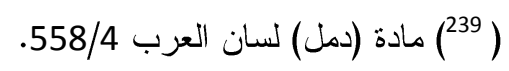

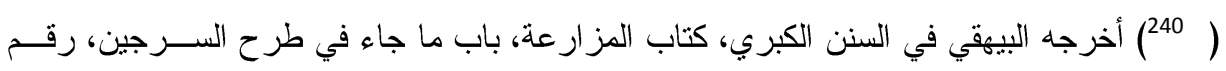

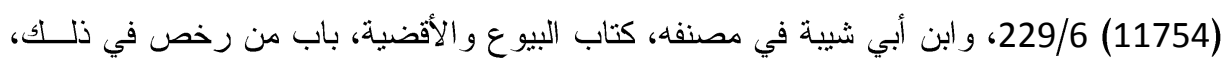

$$
\begin{aligned}
& \text { رقم (22367) 485/4. } \\
& \text { (241) مادة: (عرر) لسان العرب 555/4. }
\end{aligned}
$$

(242 السنن الكبري للبيهقي، المصدر السابق، لسان العرب، المصدر السابق. 


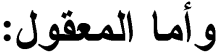

فاستدلو ا به فقالو ا: إن النجاسة تستحيل في باطن الزروع و الثـــار، فتطهـر

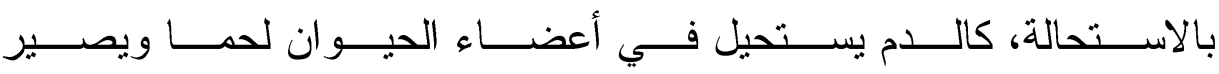
لبناب(243).

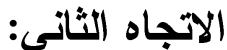

يري عدم جواز سقي الأرض الزراعية أو تسميدها بالنجاسات، وأن الزروع

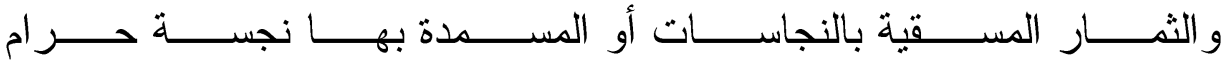

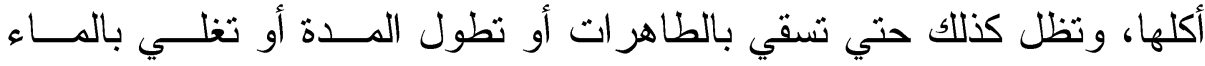

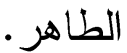

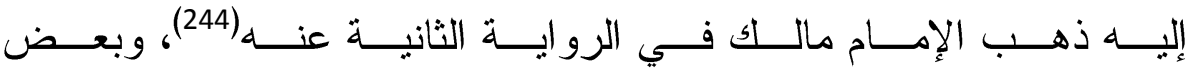

الثافعية(245)، و الإمام أحمد في الرواية الثانية عنه، وبعض فقهاء مذهبه(246) وقد استدل اصحاب هذا الاتجاه علي ما ذهبو إليه بأدلة من الأثر و المعقول:

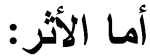
فما رواه عكرمة عن ابن عباس رضي الله عنهما أنه قــال: " كنــــ نكــري

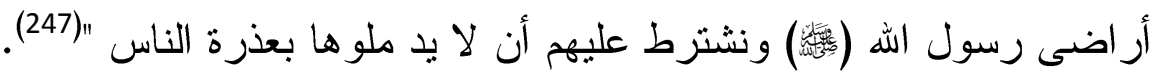

(243) المغني و الثرح الكبير 500/10، الإنصاف 138/10 277/10، المبدع 179/9، كثاف القناع 194/6.

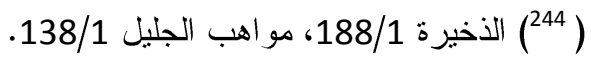

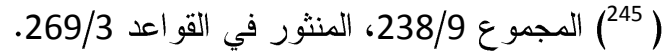

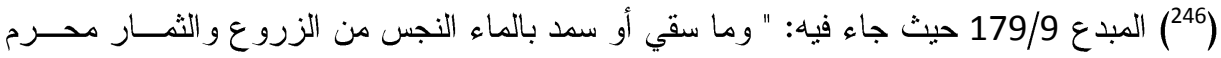

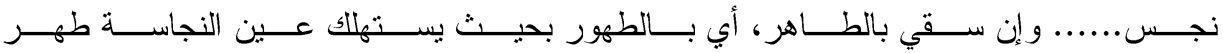

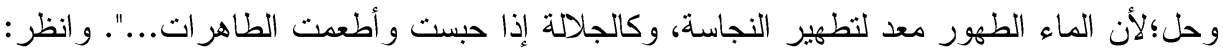

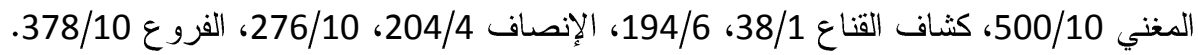

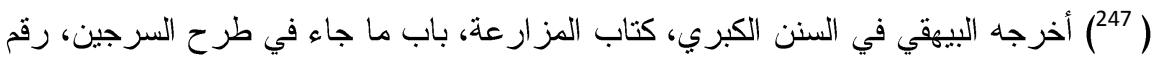
.139/6 (12097) 
وجه الدلالة: أنه لو لا أن ما يزرع في الأرض المسمدة بالنجاسات يحرم، لم

$$
\text { بكن في الاشتر اط فائدة(248). }
$$

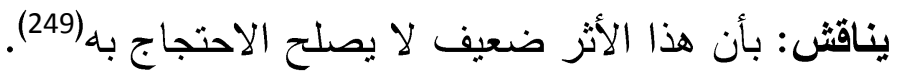
أما المعقول:

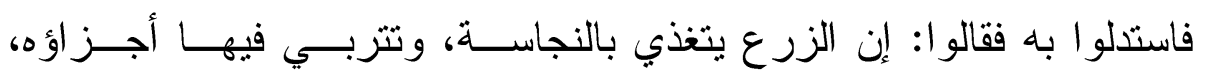

والاستحالة لا تطهر (250).

يناقش: بأن الاستحالة تطهر، فالنجاسة تستحيل في باطن النبات، كما يستحيل الدم في أغضان الحيوان لحما، ثم يصير لبناً.

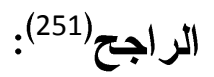

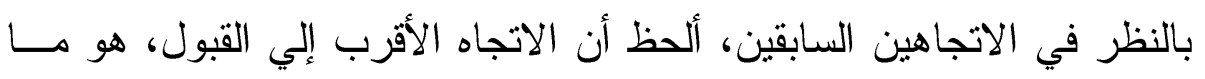

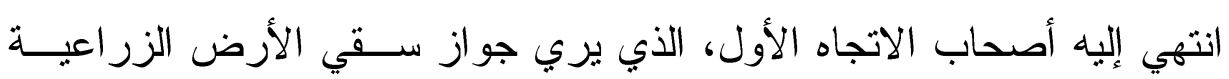

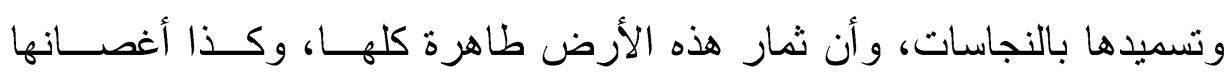

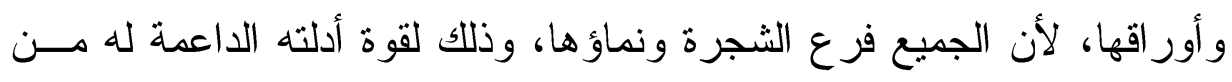

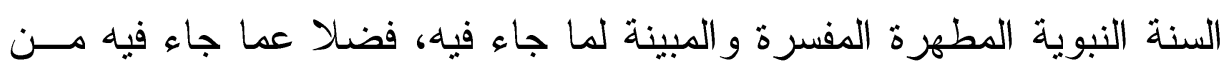
قول الصحابي ودلالة العقل عليه، وسلامته من الطعون، ومما يدعو البحث إلي

$$
\text { (248) المبدع 179/9، كثاف القناع 194/6. }
$$

(249) التلخيص الحبير 78/2، وقال الألباني: أخرجه البيهقي من طريق الحجاج بن حسان عن أبيه

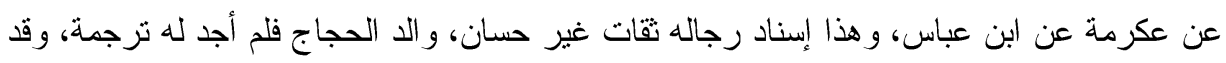

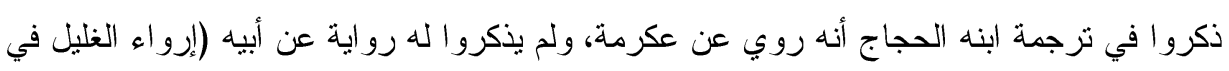

$$
\text { (250) المريج أحاديث منا السبيل 219/8) }
$$

(251) مال إلي هذا الترجيح أيضا: الدكتور عبد الله السحيباني في أحكام البيئة في الفقه الإسلامي ص 
ترجيح هذا الاتجاه أيضا، أنه يساهم إلي حد كبير في علاج مشكلة مياه الــري التي تعاني منها كثير من دول العالم في العصر الحديث ؛ نظر القلة مواردهــــا

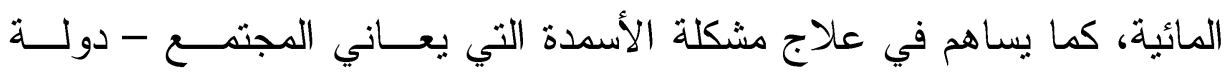

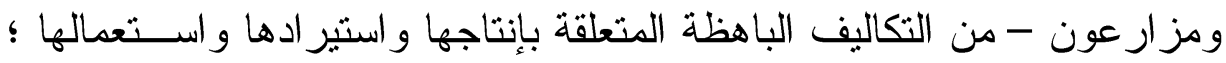

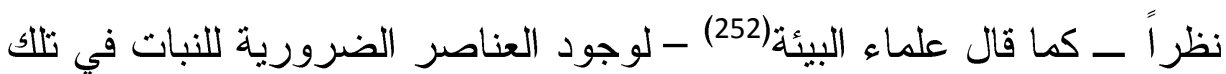
المباه. وبناءً علي هذا الاتجاه الراجح، فالزروع و الثمار المسقية بالنجاسات طاهرة

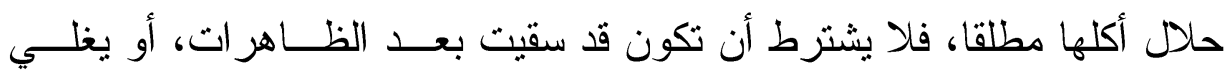

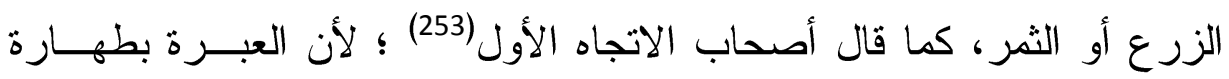

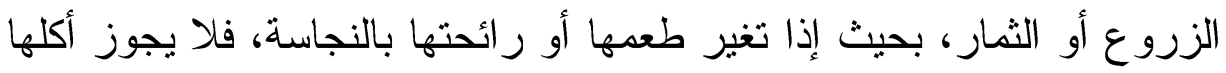
حينئذ لنجاستها: كما أنه إذا ترتب علي السقي أو التسميد بالنجاسة نجاسة ظاهر

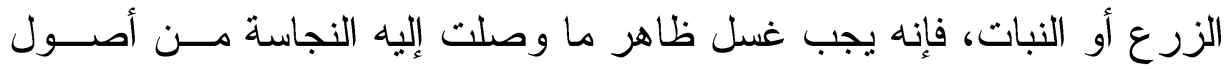

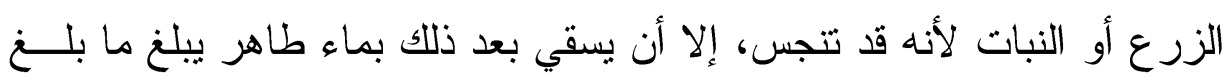
إليه النجس و المنجس، فلا يغسل بعد ذلك (254).

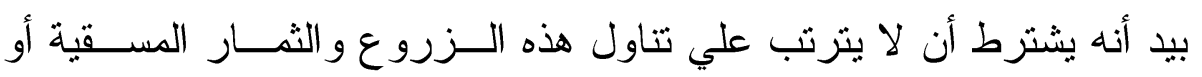
المسمدة بالنجاسة ضرر صحي، و إلا حرم تتاولها مطلقا ؛ لقوله تعالي: " وَلاً

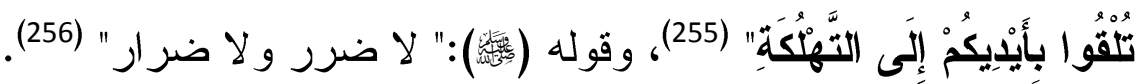

(252) معالجة مياه الصرف الصحي، بحث منشور في مجلة العلوم و الثقنية، الصادرة عن مدينة الملك

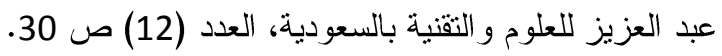

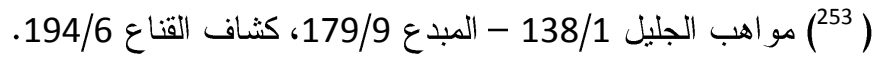

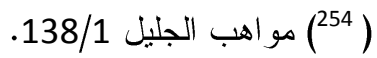
(195) (195).

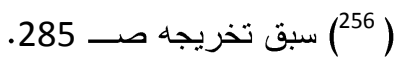


أما عن حكم استعمال مياه الصرف الصحي غير الطــاهرة - نظــــرا لعـــدم

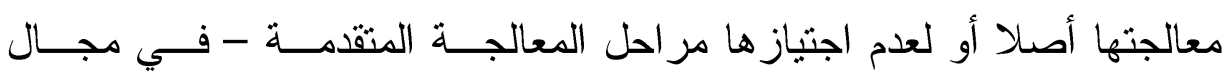
الصناعة.

فإنه إذا كان لا يترتب علي استعمال هذه المياه في هذا المجال أية أضـــرار

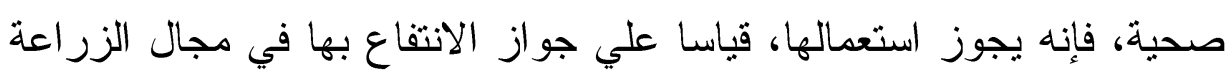

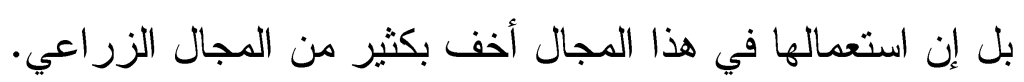

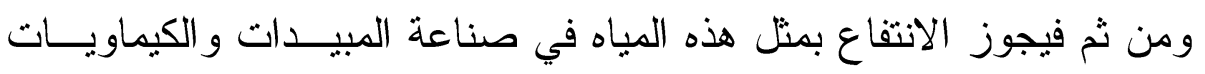
خاصة الأسمدة ؛ نظر الوجود العناصر الضرورية للنبات في ثلك المباه(257).

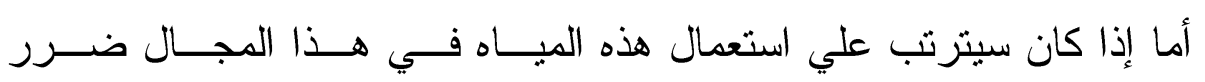
صحي،فإنه يحرم حينئذ استعمال هذه المياه لضرر ها.

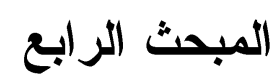

استحالة الأعيان النجسة إلي طاهرة للانتفاع بها في الفقه الإسلامي

$$
\text { أعرض لذلك في المطالب الآتية: }
$$

المطلب الأول: استحالة الخمر إلي طاهرة للانتفاع بها في الفقه الإسلامي. المطلب الثاني: ما يستحال من الميتة إلي طاهر للانتفاع به في الفقه الإسلامي. المطلب الثالث: موقف الفقه الإسلامي من الانتفاع بالخنزير فيما سوي اللحم. المطلب الر ابع: موقف الفقه الاسلامي من الانتفاع بالدم المسفوح. مون. 


\section{المطب الأول}

استحالة الخمر إلي طاهرة للانتفاع بها في الفقه الاسلامي

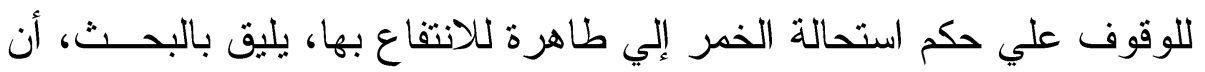

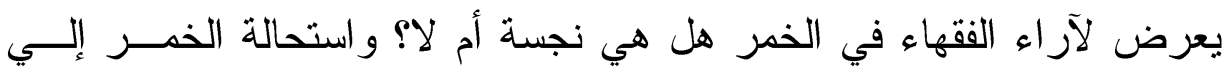

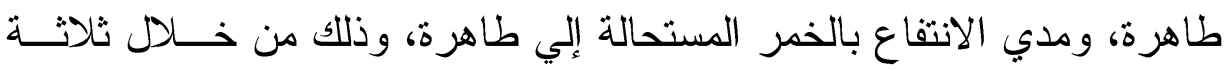

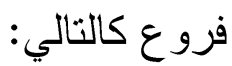

الفرع الأول: آراء الفقهاء في نجاسة الخمر . الفرع الثاني: استحالة الخمر إلي طاهرة للانتفاع بها في الفقه الإسلامي. الفرع الثالث: الانتفاع بالخمر المستحالة إلي طاهرة في الفقه الإسلامي. الفرع الأول: آراء الفقهاء في نجاسة الخمر

من المعلوم أن شرب الخمر حرام علي كل مسلم ومسلمة، فمن شربها فإنــهـ يستحق العقوبة المقررة لهذه الجريمة. و الأصل في ذلك الكتاب و السنة و الإجماع.

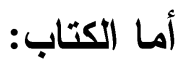

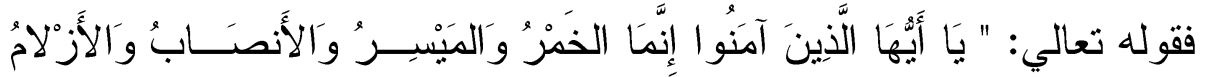

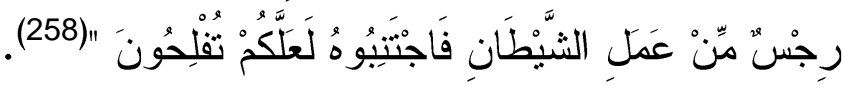
وأما السنة:

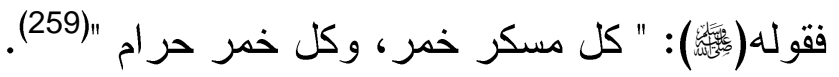

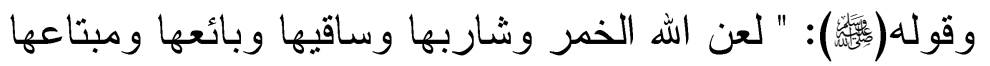
و عاصر ها ومعتصو ها وحاملها و المحمولة إليه "(260)

(90) (258) سورة المائدة، الآية (250).

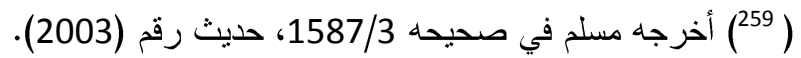

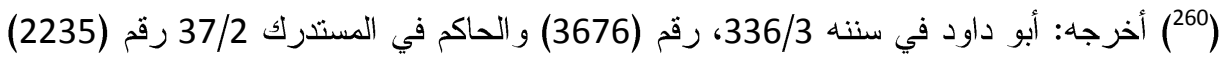
و أحمد في مسنده 9/10 رقم (5716) و البيهقي في سننه الكبرى 327/5، 3236/3، رقم (10559). doi: $10.12816 / 0004230$ 


\section{وأما الإجماع:}

فقد أجمعت الأمة علي تحريم الخمر علي المسلم، وأنه إذا شربها يجب إقامة الحد عليه(261).

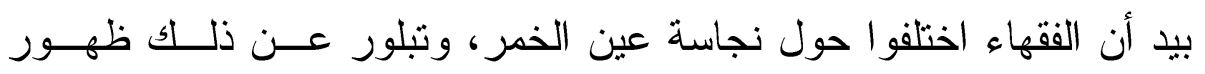
اتجاهين:

الاتجاه الأول: يري أنصاره أن الخمر نجسة العين نجاسة مغلطـــة، كـالبول

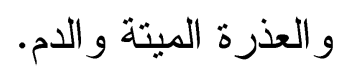

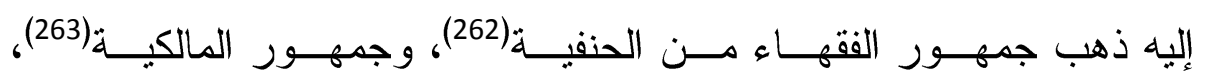
و الثافعية(264)، و الحنابلة (265).

وقد استدل أصحاب هذا الاتجاه علي ما ذهبوا إليه بأدلة من الكتاب و المعقول. أما الكتاب:

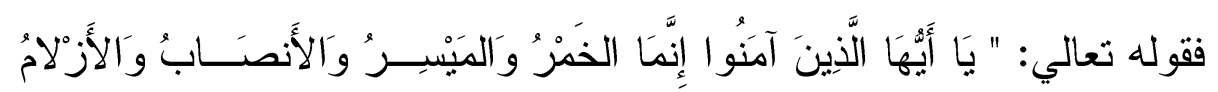

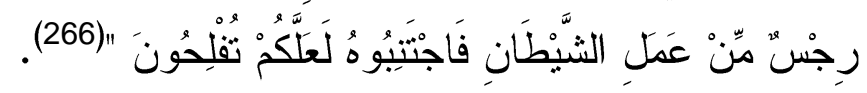

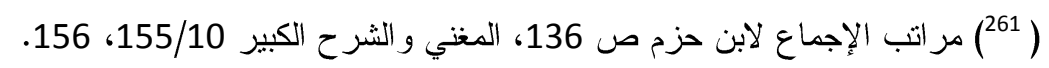

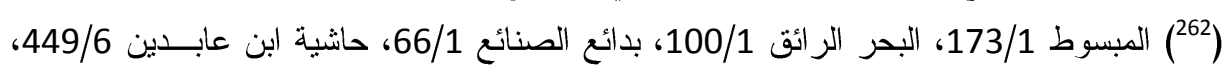
تكملة شرح فتح القدير 28/9.

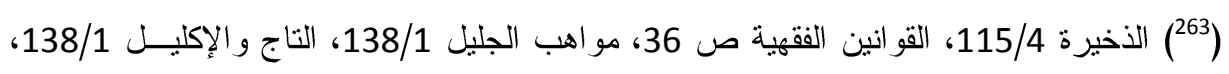

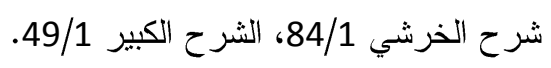
(264) المجموع 563/2، روضة الطالبين 122/1، مغني المحتاج 110/1، شرح ح جلاد الدين المحلي وحاثيتي قليوبي وعميرة عليه 68/1، وقد حكي الإمام القرطبي عن المزني صاحب الثناجي الثافعي القول

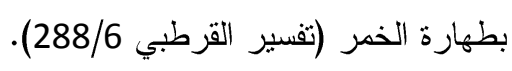

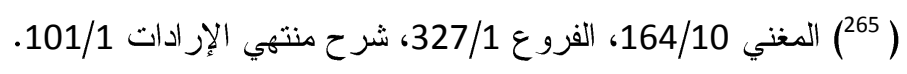

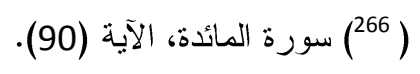




\section{وجه الدلالة:}

أن الله عزوجل سمي الخمر رجساً، و الرجس هو النجس، كما أنـــهـ ســبحانه

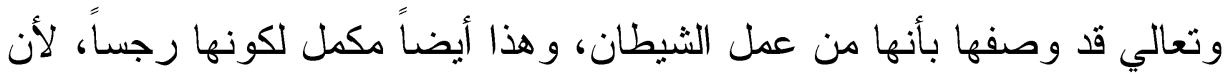

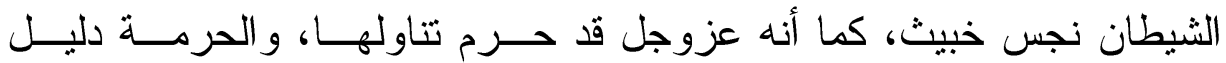

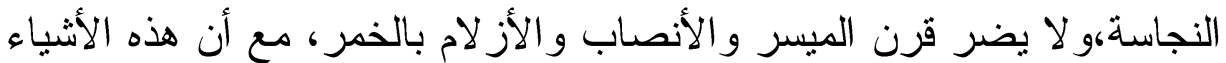

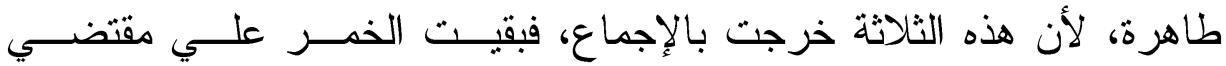
الكلام (267)

نوقش هذا الاستدلال: بأن القول بنجاسة الخمر حكم شرعي و لا نص فبه،و لا

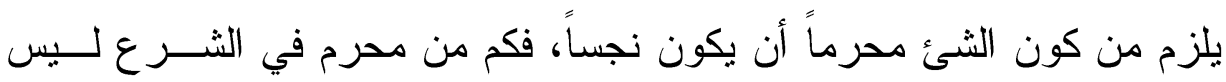
(268)

\section{أجيب عنه من وجهين: - أنسي}

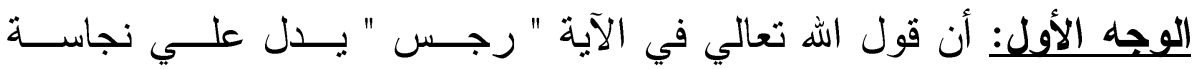
الخمر؛ لأن الرجس في اللغة النجاسة.

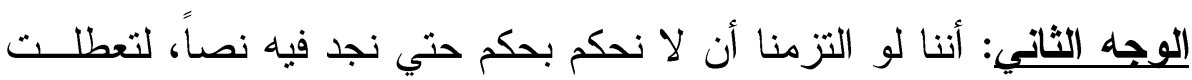

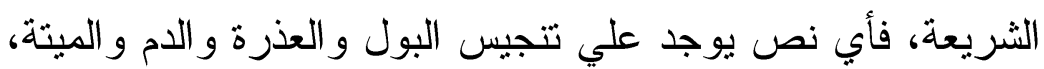

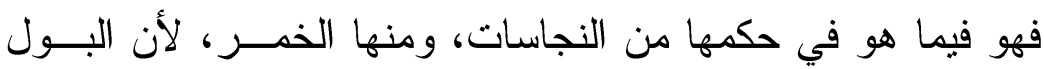
و العذرة و الدم و الميتة، إنما هي الظو اهر و العمومات و الأقيسة (269)

(267) تفسير الفخر الر ازي 1704/1، تفسير القرطبي 287/6، بدائع الصنائع 66/1، حاثية ابـنـ عابدين 449/6، تكملة شرح فتح القدير 289/6.

$$
\begin{aligned}
& \text { (268) تفسير القرطبي عابن 289/6. } \\
& \text { (269) }
\end{aligned}
$$




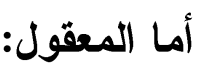

فاستدلو ابه فقالو ا إنه لو كانت الخمر طاهرة، لفات الامتنان بكــون شــراب

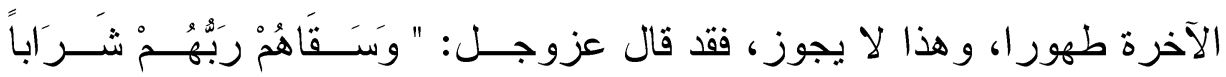

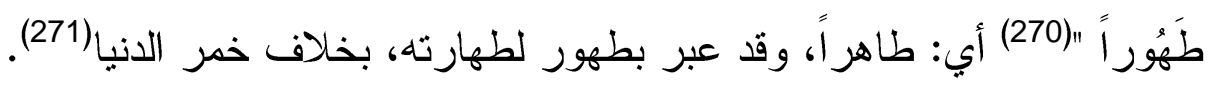

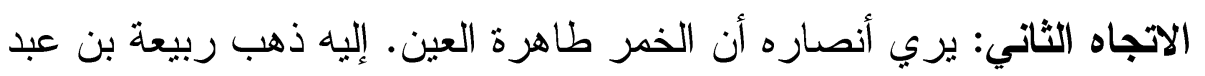

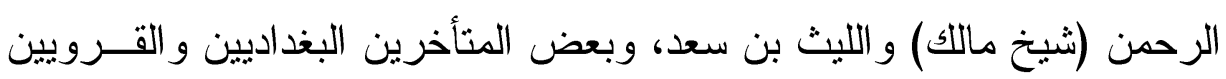
من المالكية(272).

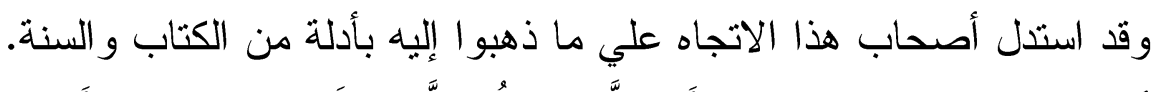

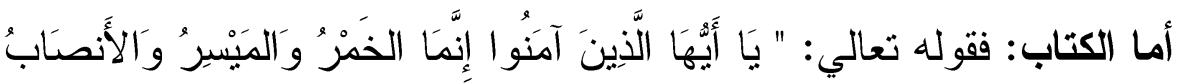

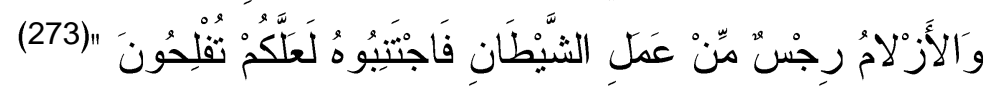

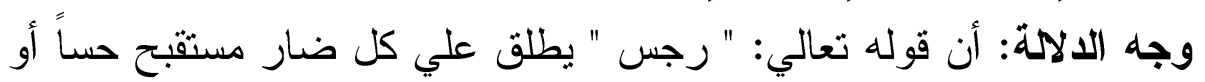

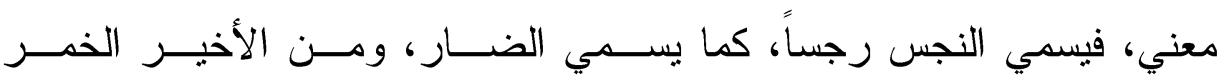
و الميسر و الأنصاب و الأزلام (274).

يناقش: بأننا لا نسلم بأن الرجس معناه الضار ؛ لأن الأن الرجس فى اللغة: هــــ

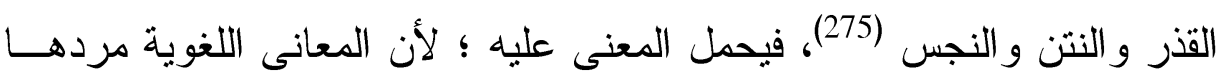
إلى أهل اللغة. 


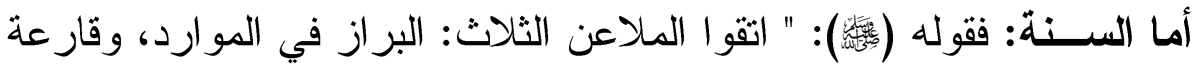
الطريق، و الظل "(276).

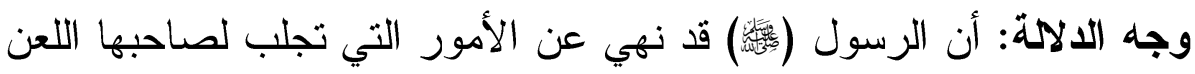
و الثنم و السب، ومنها البول و التبرز و إلقاء النجاسات في طريق المسلمين، فلو كانت الخمر نجسة ما سفاك الصحابة رضوان الله عليهم الخمر - عند نزول آية ولية تحريم الخمر - في طرق المدينة(277). نوقش هذا الاستدلال من وجوه:

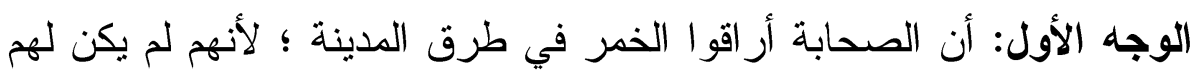

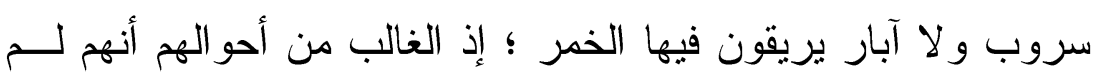

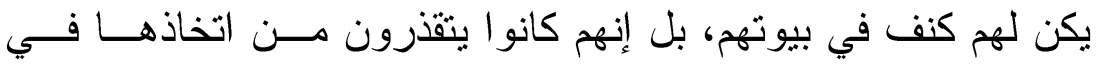

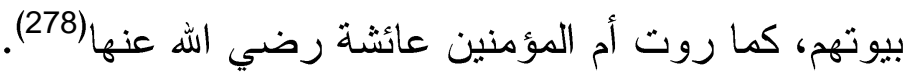

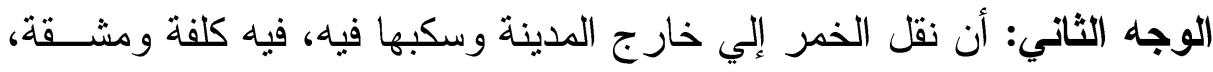
كما يلزم منه تأخير ما وجب علي الفور ، وهذا لأل يجوز (279). الوجه الثالث: أن طرق المدينة كانت واسعة، ولم تكن الخمرة من الكثرة بحيث

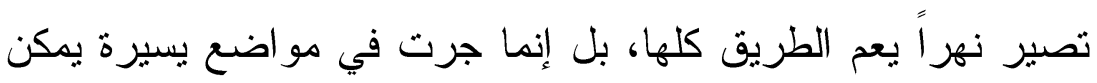
التحرز عنها(280).

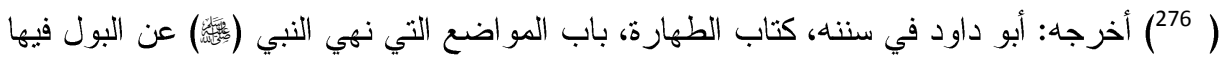
7/1 رقم (26) وقال الألباني: حديث حسن، و ابن ماجه، كتاب الطهارة، باب النهي عن الخلاء علي

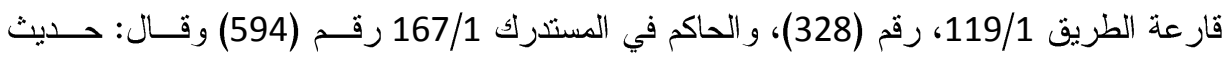

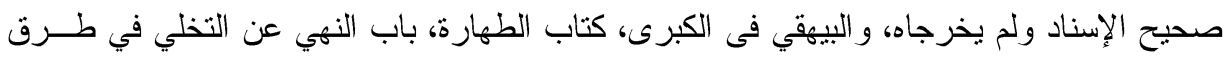
الناس 97/1، رقم (480).

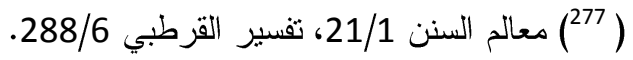
(289/9 (278) تفسير القرطبي (289) 288/6 (289) تفسير القرطبيز (280) تفسير القرطبي 288/6، 289. 


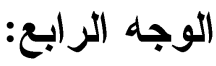

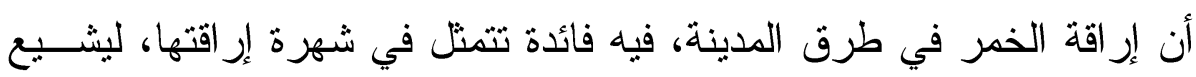
العمل على مقتضي تحريمها من إتلافها، و أنه لا ينتفع بها.

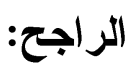

هذا: و الذي بطمئن القلب إلي رجحانه، هو ما ذهب إليه أصـــاب الاتجــاه

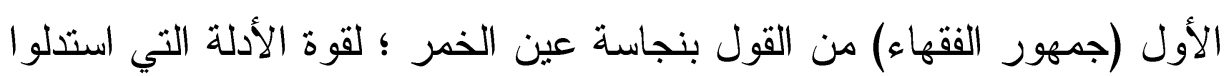

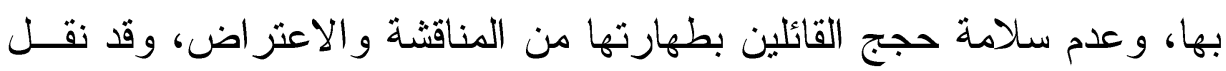
الشيخ أبو حامد الإسفر اييني الإجماع على نجاسة الخمر. (282) الفرع الثاني

\section{استحالة الخمر إلي طاهرة للانتفاع بها في الفقه الإسلامي}

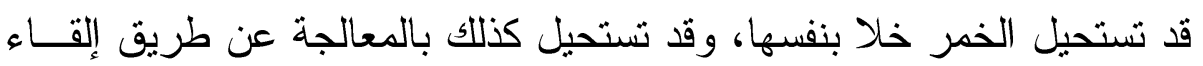

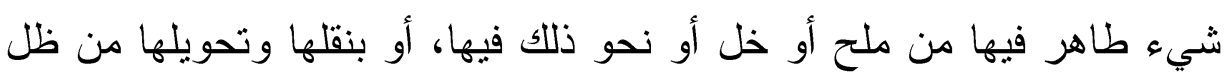
إلي شمس أو عكسه، أو بكثف رؤوسها وتعريضها للحر أو الريح، أو نحسو ونه ذلك.

فاذا استحالت الخمر خلا، فهل تكون طاهرة يحل اكلها و الانتفاع بها أم لا ؟

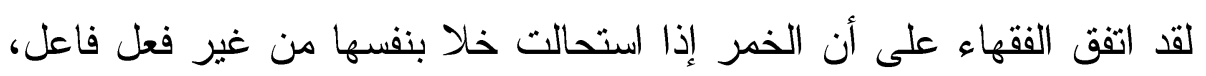
فإنها تكون طاهرة، يحل الانتفاع بها مطلقا. (283)

$$
\begin{aligned}
& \text { (281) تفسير القرطبي 289/6. } \\
& \text { (282) مغني المحتاج 110/1. }
\end{aligned}
$$

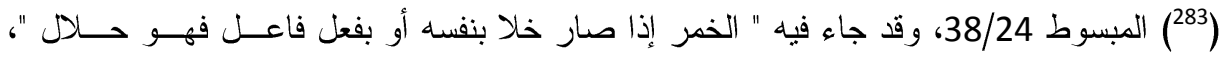

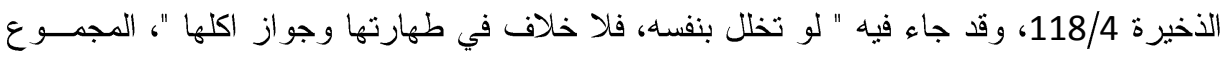
299 
بيد أنهم اختلفو افى طهارتها وحلها إذا استحالت خمر ا بالمعالجة وتبلور عن ذلك ظهور اتجاهين:

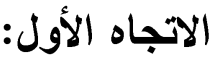

يري أنصاره أن الخمر إذا استحالت خلا بالمعالجة عن طريق إلقــاء شــيء طاهر فيها أو بنقلها وتحويلها أو تعريضها للحر أو الريح، فإنها تكون طــاهرة يحل الانتفاع بها.

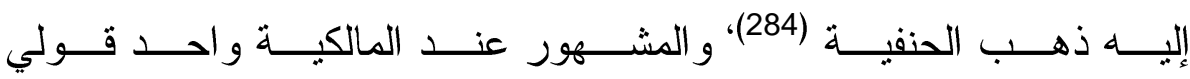
ماللك(285)، ووجه عند الحنابلة، وبه قال عطاء وعمرو بن دينــار و الحسـارث العكلي (286.).

وقد استدل اصحاب هذا الاتجاه على ما ذهبوا اليه بأدلة من السنة و المعقول.

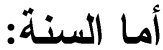

[أ] ما روي عن أم سلمة رضي الله عنها أنها قالت: قال رســول الله الدباغ يحل من الميتة كما يحل الخل من الخمر " (287).

574/2، وقد جاء فيه " الخمر نظهر بالاستحالة إلي خل " المغني 165/1، وقد جاء فيه " و إن قلب

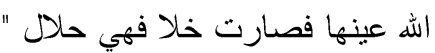

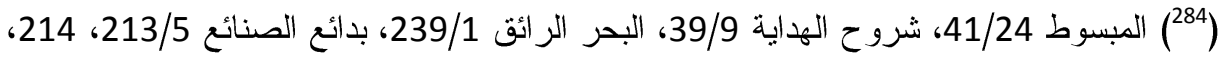

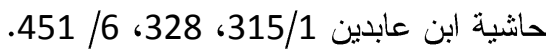

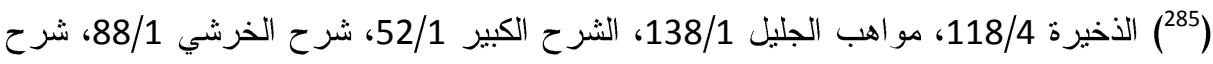

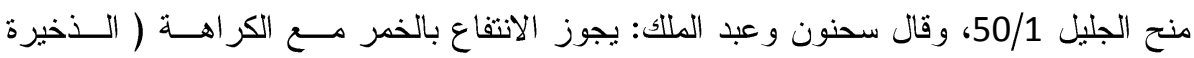

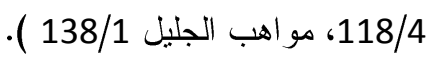

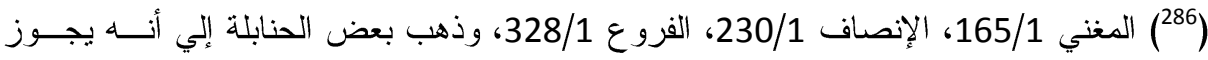

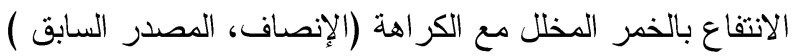

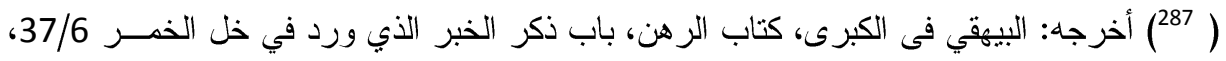

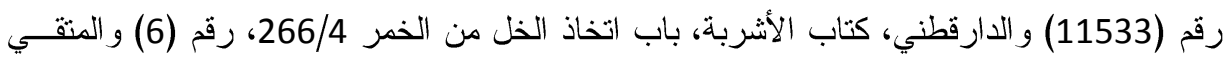
doi: $10.12816 / 0004230$ الهندي في كنز العمال 419/9، وقل (1533) (26768) 


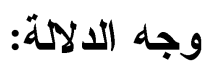

الحديث يدل دلالة واضحة على أن الخمر إذا خلت،، فإنها تكون حلالاً (288). نوقش هذا الاستدلال من وجهين:

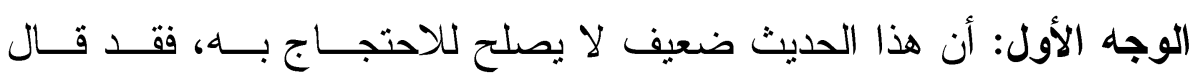

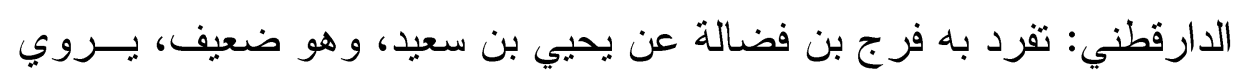

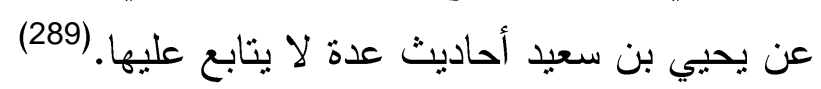

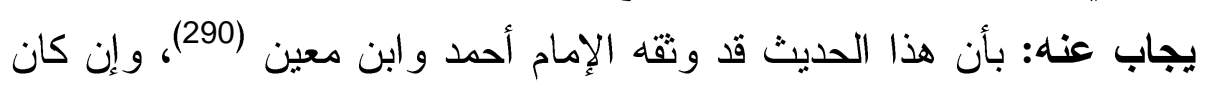
التجريح مقدم على التعديل عند التعارض. (291) الوجه الثاني:

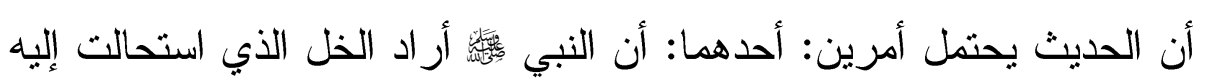

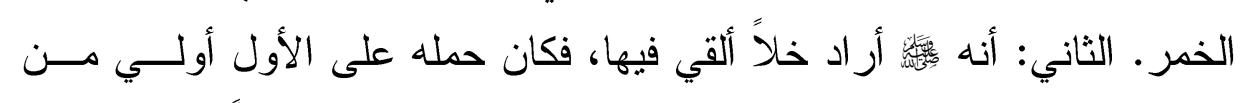

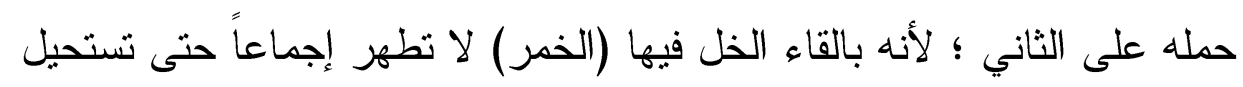

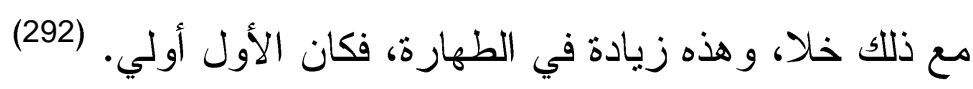

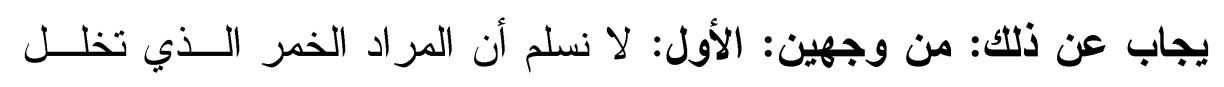

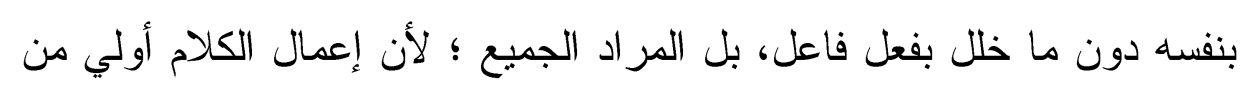
إهماله. (293)

(288) سنن البيهقي 37/6، المبسوط 44/24. تبيين الحقائق 48/6.

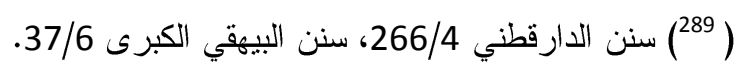

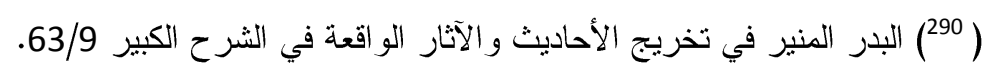

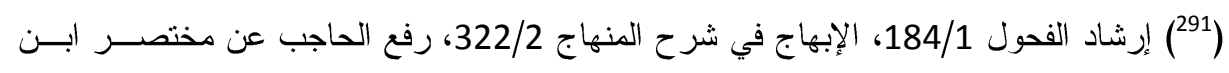

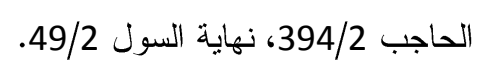

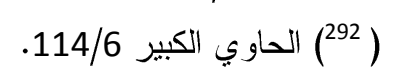

(293) الأشباه و النظائر لابن نجيم ص 135 135، الأثباه و النظائر للسيوطي ص 128. 


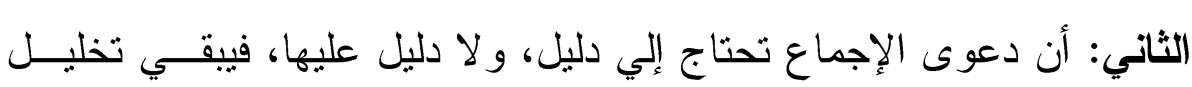
الخمر على الإباحة مطلقاً.

[ب] ما أخرجه الإمام مسلم عن أم المؤمنين عائشة رضي الله عنها، أن النبي (294) و (294).

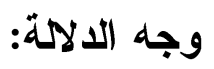

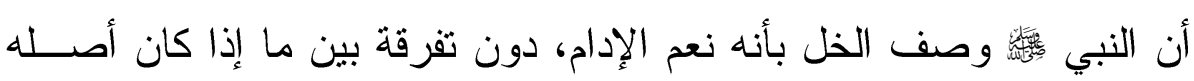

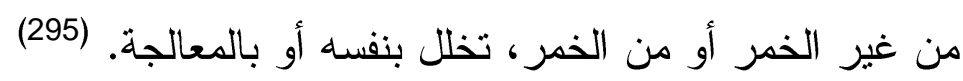
نوقش هذا الاستلال من وجهين:

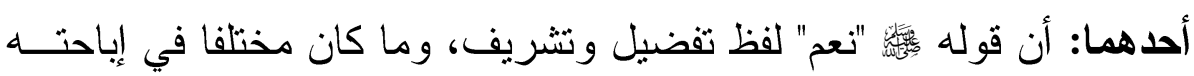
لا يستحق التفضيل و التثريف، وتخليل الخمر مختلف فيه، فلم يجز أن يكــون داخلا في عموم لفظ ينافيه. (296)

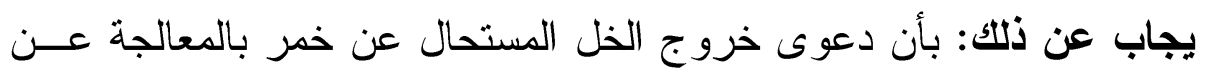

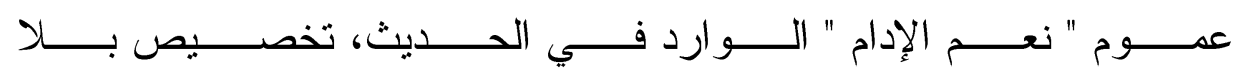

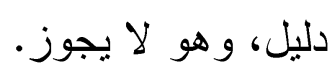

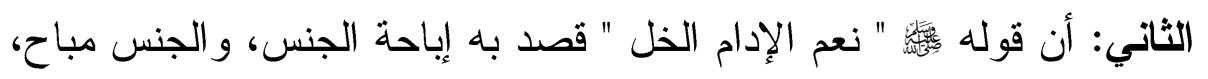

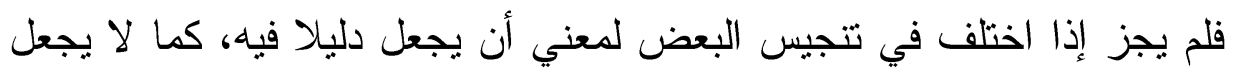

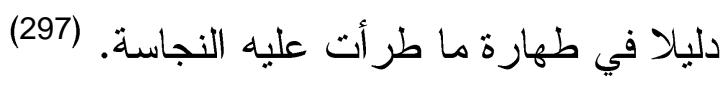

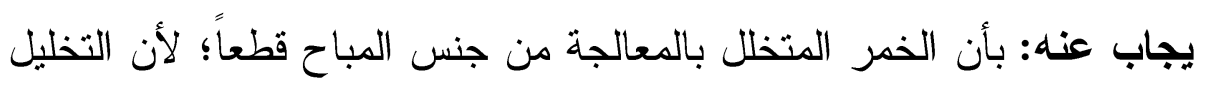

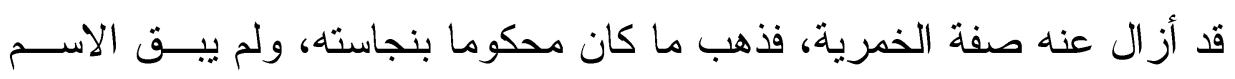

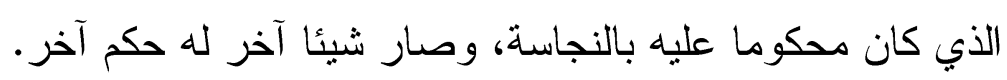
(294) صحيح مسلم، كتاب الأطعمة، باب فضيلة الخل و التأدم به 163/3، رقم (2051)

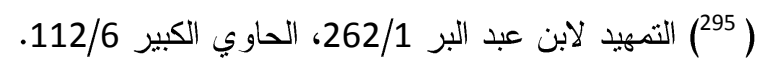

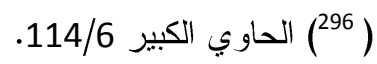
(297)

doi: $10.12816 / 0004230$ 


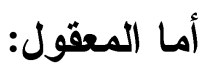

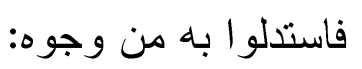

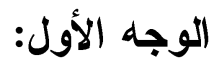

أن الخمر عين نجست لعارض، فجاز أن تطهر باستحالتها خلا بفعل الآدمي، كجلد الميتة فإنه يطهر بالدباغ وهو فعل آدمي (298).

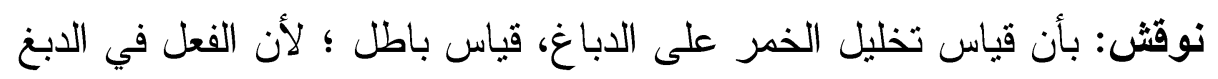
غير محظور، فجاز أن بطهر به، وفي الخمر محظور، فلم يجز أن بطهر بهاه، كذبح الثاة في غير مذبحها. (299) أجيب عنه:

بأن الخمر جوهر فاسد، وإصلاحه بإز الة صفة الخمرية عنه، و التخليل إزالة

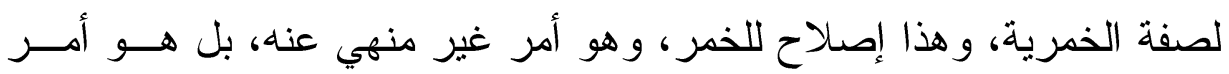
مشروع، وهو كدبغ الجلد، فإن عين الجلد نجس، ولهذا لا يجوز بيعه. (300)

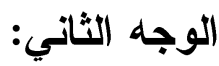

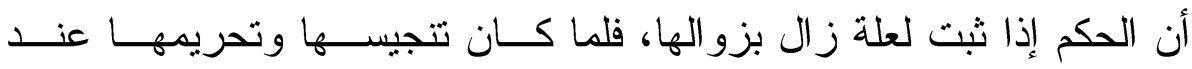
المخالف لحدوث الثدة فيها، وعندنا لانطلاق اسم الخمر عليها، وكان تخليلهـ يزيل الثدة منها، وينقل اسم الخمر عنها،وجب أن يزيل تتجيسها وتحريمها.(301) نوقش: بأن نجاسة الخمر قد زالت بالتخليل، و إنما بقي نجاسة الخل.(302)

$$
\begin{aligned}
& \text { (298) المبسوط 42/24، تكملة شرح فتح القدير ـ (39/9. }
\end{aligned}
$$

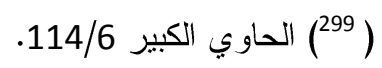

$$
\begin{aligned}
& \text { (400) المبسوط 44/24، ثبيين الحقائق 48/6. } \\
& \text { (35/24، 401 الهداية 39/9، الحاوي الكبير 112/6. 112/6. }
\end{aligned}
$$

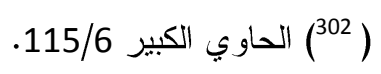


يجاب عنه: بأنه إذا كانت النجاسة قد ذهبت عن الخمر بالتخليل، فيجــب أن تتخلع عن الخل من باب أولي ؛ لأن الخل قد استحال عنها، فيأخذ حكمها. الوجه الثالث:

أن من حكم الخمر مع تتجيسها وتحريمها، تفسيق متتاولها ووجوب الحد على شاربها، فلما كان تخليلها مانعا من تفسيق متتاولها ومسقطا لوجوب الحد على

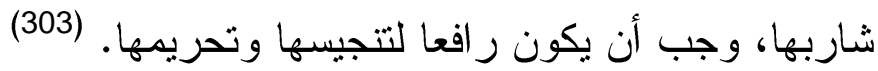

\section{نوقش}

هذا الوجه بما نوقش به الوجه الثاني، ويجاب عنه بما أجيب عن الثاني. الوجه الر ابع: أن تخليل الخمر على ضربين: تخليل بطرح شيء فيها،وهيه تخليل

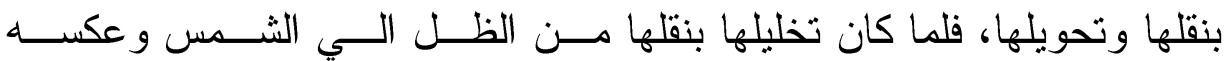

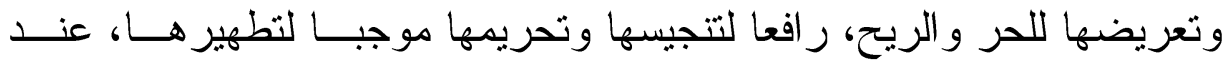
بعض الثافعية وبعض الحنابلة، وجب كذللك أن يكون تخليلها بطر ح شيء فيها

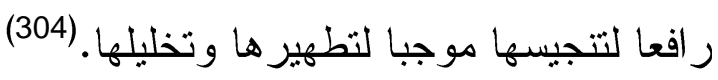

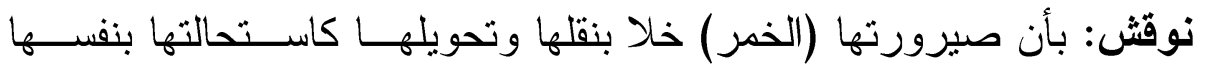

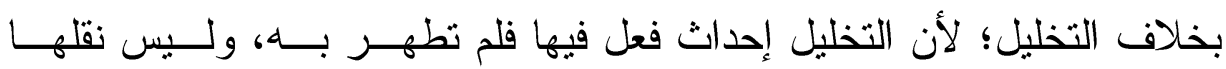
وتحويلها إحداث فعل فيها، فجاز أن تطهر به. (305)

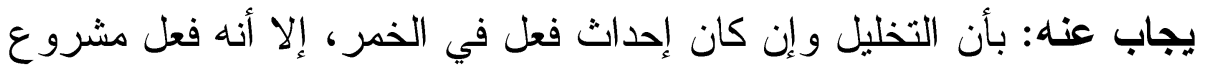

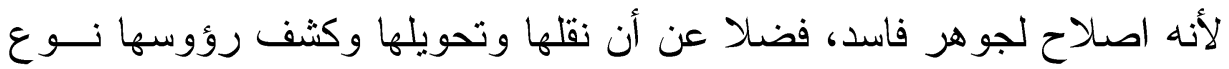
من المعالجة كإحداث فعل فيها، فتطهر في الحالة الثانية كالأولي. 
الاتجاه الثاني:

يري أنصاره أن الخمر إذا استحالت خلا بالمعالجة، فلا تطهر، و لا يحل أكلها أو الانتفاع بها.

(307)

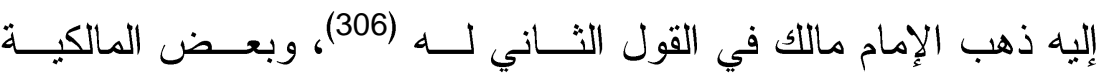

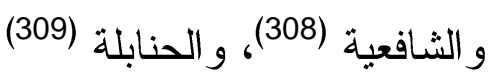
وقد استدل اصحاب هذا الاتجاه على ما ذهبوا اليه بادلة من السنة و الإجمــاع

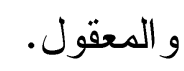

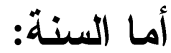

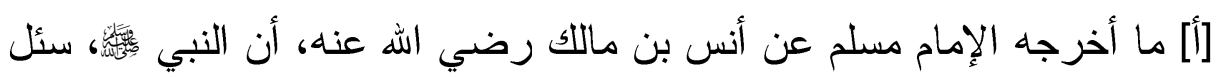
عن الخمر تتخذ خلاً، فقال " لا " (310.

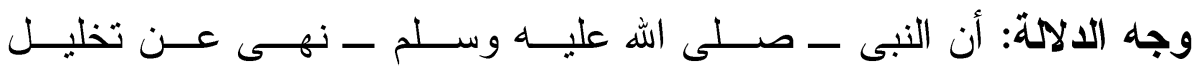

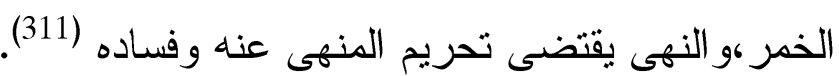

139/1.

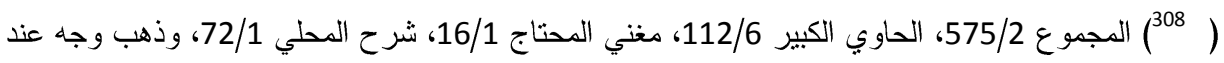

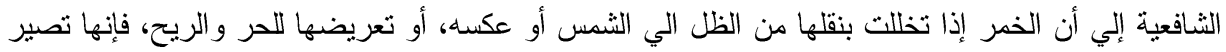

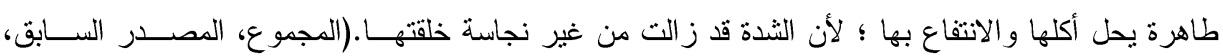

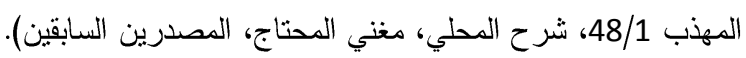

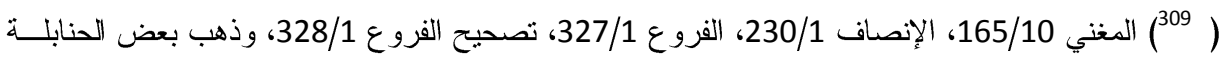

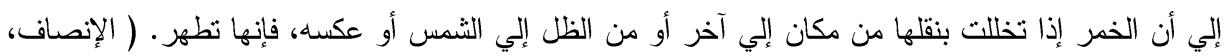
وتصحيح الفروع، المصدرين السابقين).

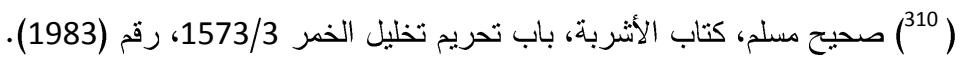
(1311) شرح السنة للإمام النبوى، الحاوى 113/6، المغنى 561/10. 


\section{نوقش هذا الاستدلال من وجهين:}

الوجه الأول: أن النهى عن تخليل الآ من وجهن: الخمر فى الحديث، المر اد به أن بستعمل

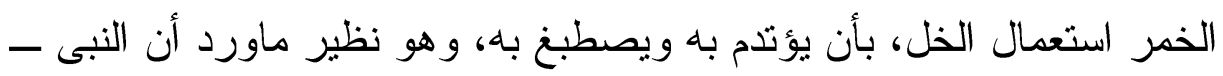

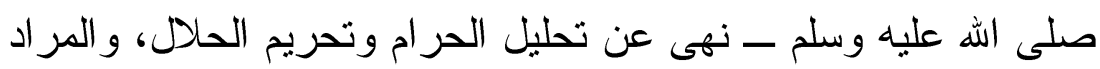

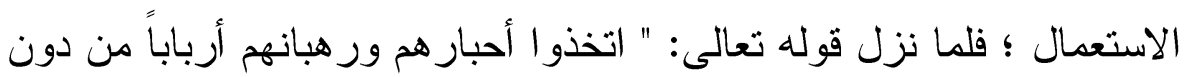

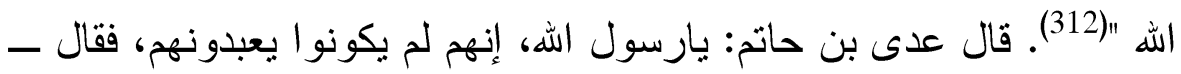

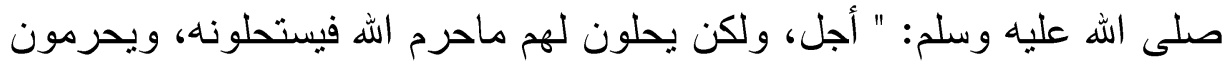

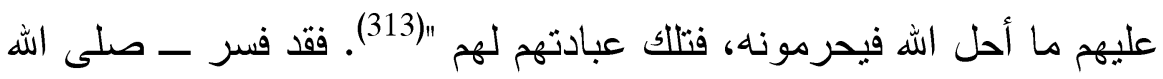
عليه وسلم _ الاتخــاذ بالاستعمال (314).

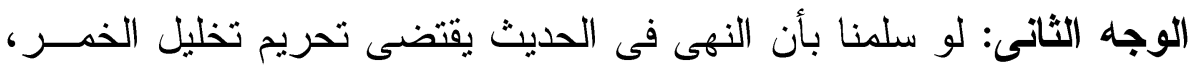

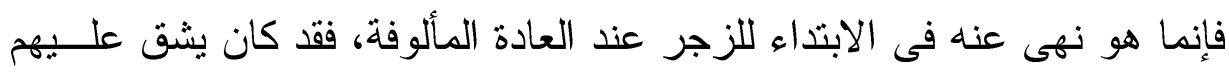

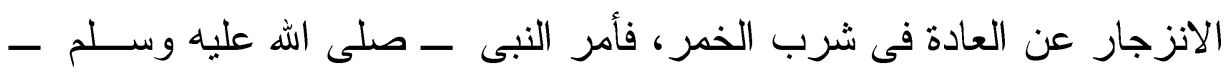

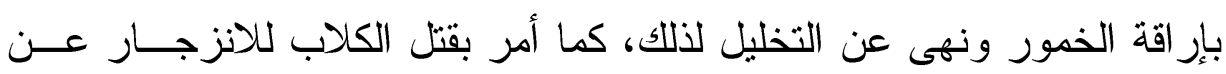
العادة المألوفة فى اقتناء الكلاب (315)

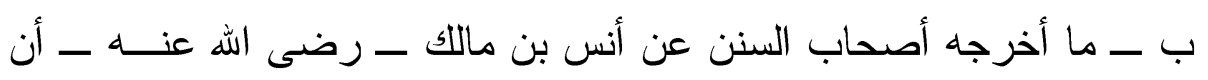

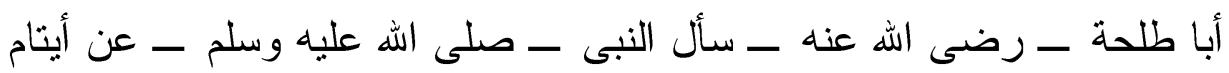

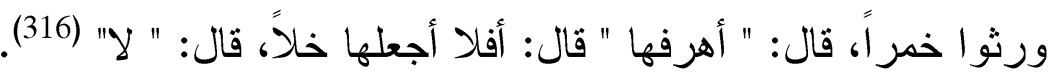

$$
\text { سورة التوبة، بعض الآية (31). }
$$

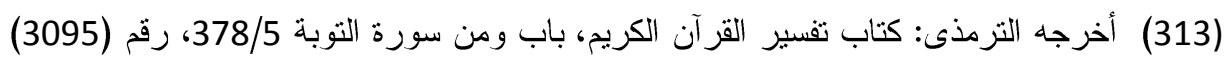

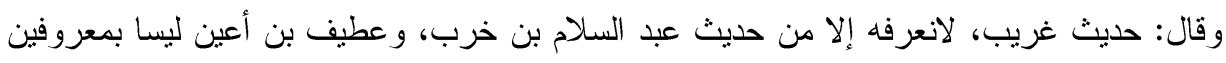

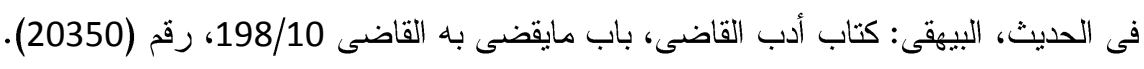

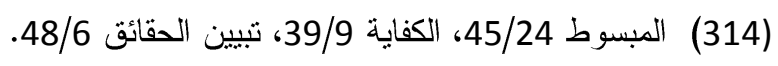

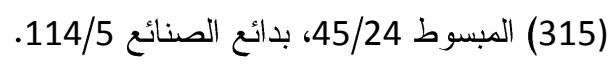

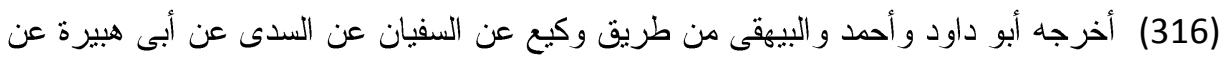

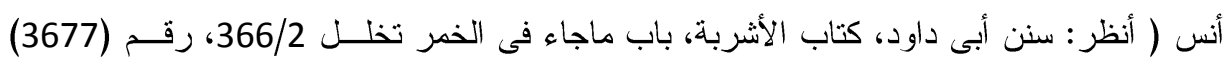
وقال: الألبانى: حديث صحيح. مسند أحمد 226/19، رقم (12189). سنن البيهقى، كتاب الــرهن، doi: 10.12816/0004230 


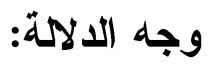

أـــ أن النبى ـ صلى الله عليه وسلم ــ منعه من تخليلها، ولو كان تخليلها سبياً لطهارتها و إباحتها لأمر به ولم يمنع منه.

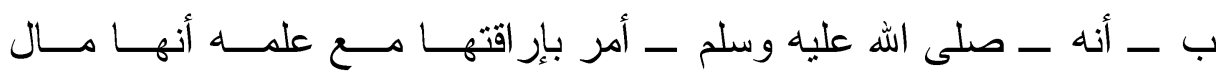
يتيم،و أمو ال اليتامى يجب حراستها، فلو كان التخليل سبياً لطهارتها و إباحتها

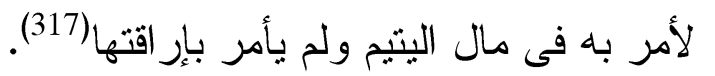

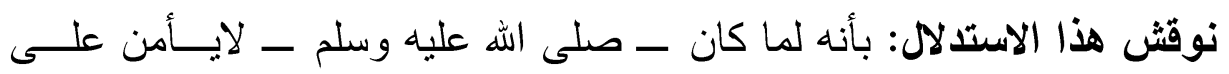

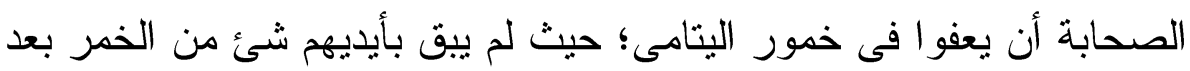

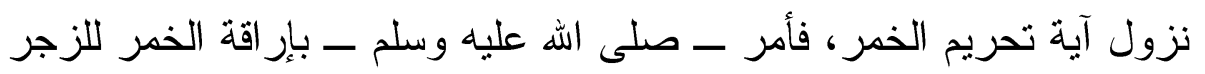

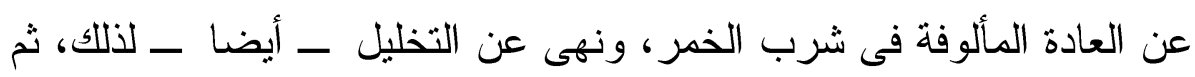
إن الواجب على الوصى المنع من إفساد مال اليتيم لا إصلاح مافسد منه، ألا

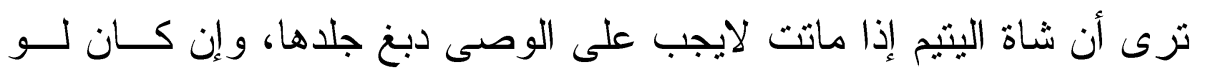

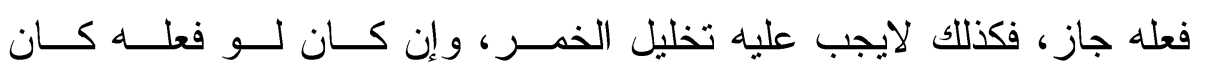
جائز | (318).

أما الإجماع: فقد روى أسلم ـ مولى عمر بن الخطاب ـ رضى الله عنه ـ عن عمر أنه صعد المنبر فقال:" لايحل خمر أفسدت حتى يبدى اله فسادها،فعند

باب العصبر المرهون بصير خمراً 37/6، رقم (11529). و أخرجه الترمذى فـى ســنـه: كتــاب

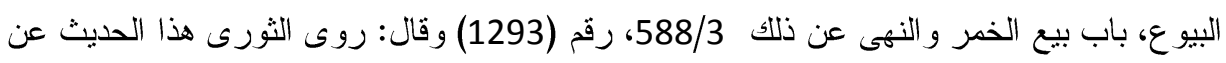
السدى عن يحيى بن عباد عن أنس أن أبا طلحة كان عنده، وهذا أصح من حديث الليث.

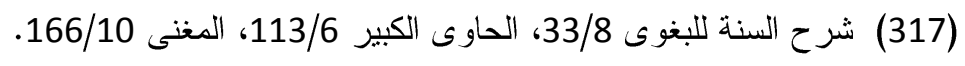
(318) المبسوط 45/24، 46، بدائع الصنائع 114/5. 
ذللك يطيب الخل، و لابأس على امرئ أن يبتاع خلاً وجده مع أهل الكتاب مالم يعلم أنهز تعدوا إفسادها " (319).

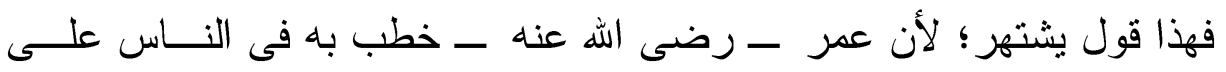
المنبر دون نكير، فكان إجماعا.

ومعنى كلام عمر :أن الخمر إذا خللت فصارت خلاً، لم يحل ذلك الخل، لكن لو قلب اله الخمر خلاً بغير علاج آدمى، حل ذلك الخل، وهذا معنى قولــه: "

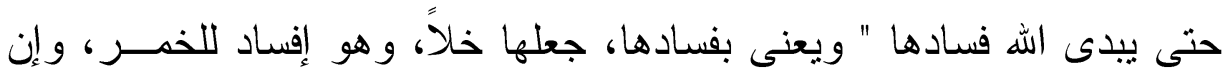

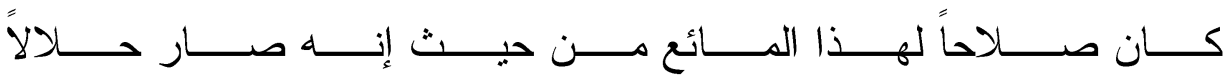
ومالةً (320).

يناقش: بأننا لانسلم الإجماع ؛ فقد خالف عمر بعض الصــحابة، فقــد روى

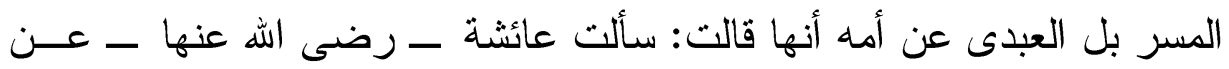
خل الخمر، قالت: " لابأس به، هو إدام " (321).

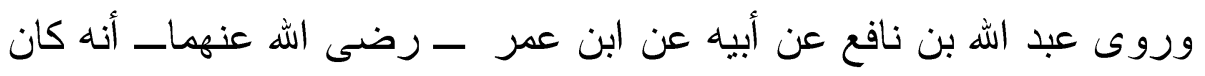

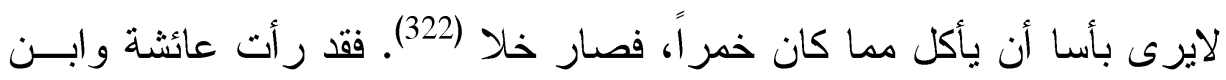

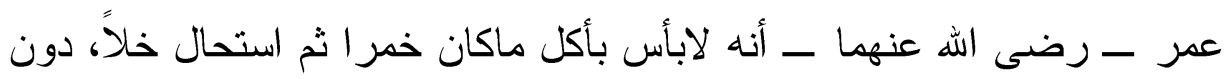
تفرقه بين ما إذا كان قد استحال بنفسه أو بفعل آدمى. أما المعقول: فاستدلو ا به من وجهين:

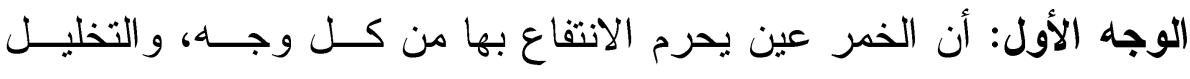
تصرف فيها على قصد التمول، فيكون حر اماً كالبيع و الثر اء، وكما لو ألقى فى الثى

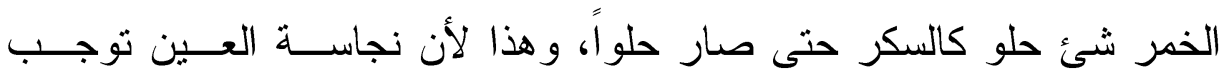

$$
\begin{aligned}
& \text { (319) سنن البيهقى الكبرى 63/6، رقم (11201) كنز العمال 453/5، رقم (41797). }
\end{aligned}
$$

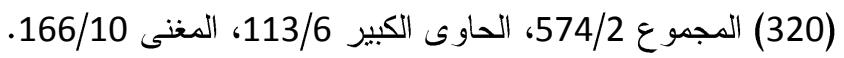

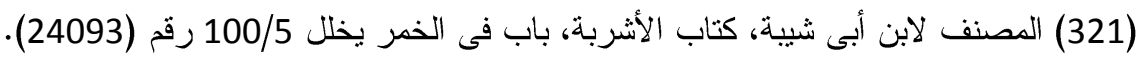

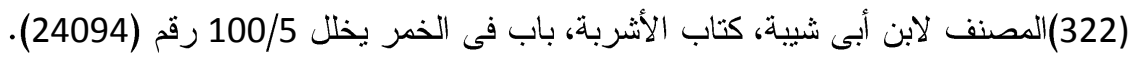

$$
\begin{aligned}
& \text { doi: 10.12816/0004230 }
\end{aligned}
$$




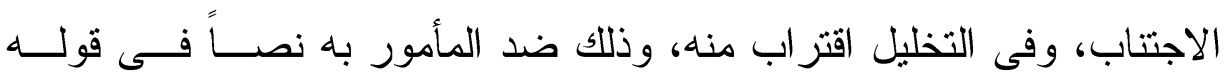

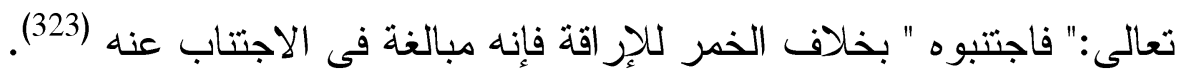
نوقش: بأن التخليل ليس بتصرف فى الخمر على قصد التمول، بل هو إتلاف

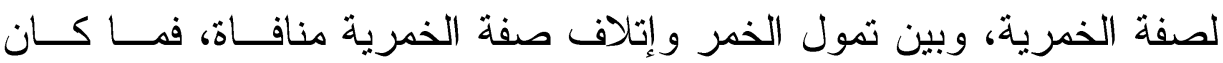

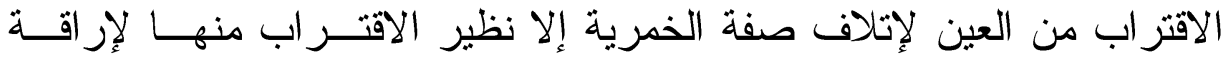
العين،وذلك جائز شرعاً.

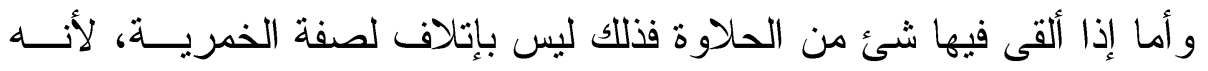

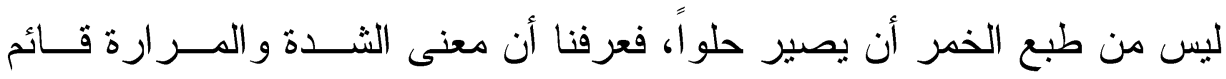

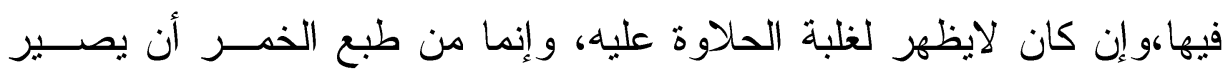
خلا،فيكون التخليل إتلافاً لصفة الخمرية (324). الوجه الثانى: أن مايلقى فى الخمر يصبر نجساً بملاقاة الخمر إياه، ومايكون

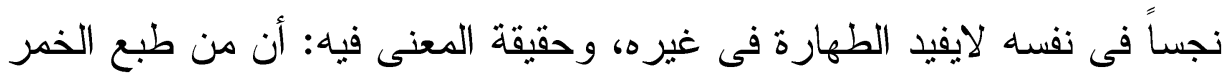

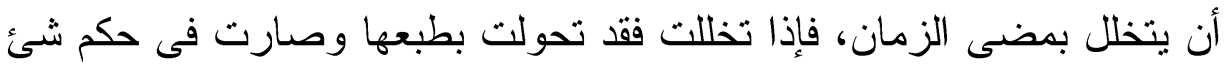

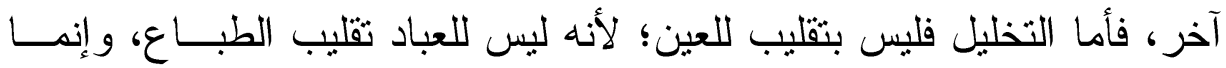

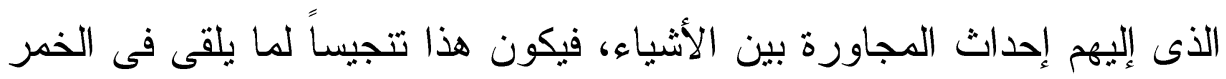

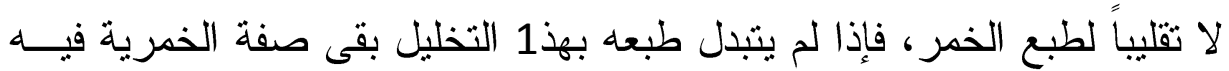
و إن كان لم يطهر، و هذا بخلاف جلد الميتة إذا دبغ، فإن نجاسة الجلد بما اتصل

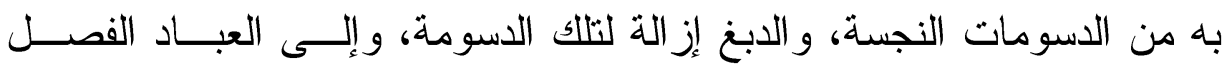

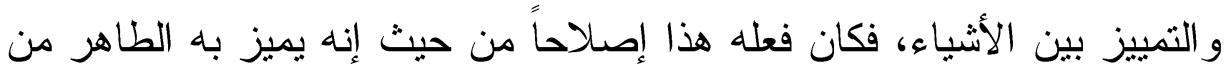


النجس، أما نجاسة الخمر فلعينها لا لغير اتصل بها، و إنما تتعدم هـــه الصــفة بتحولها بطبعها و لا أثز للتخليل فى ذلك (325). نوقش هذا الوجه من وجوه الوجه الأول: أن المقتضى لتتجيس الخمر ومالابسها هو وصف الإنه الإسكار وقد ذهب بالتخليل، فيطهر ما فى أجزاء الدواء المعالج به، فلا ينجس الخل (326). الوجه الثانى: نحن نسلم أن تقليب الطباع ليس إلى العباد، و إنما إليهم إحداث المجاورة، ولكن إحداث المجاورة بين الخل و الخمر يقوى على إتـلاف صــفة إلها

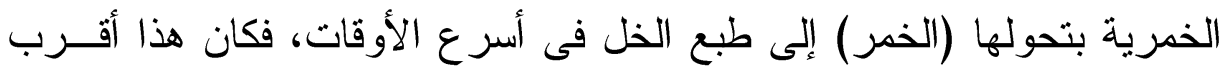

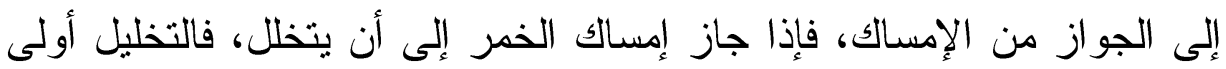
بالجواز (327).

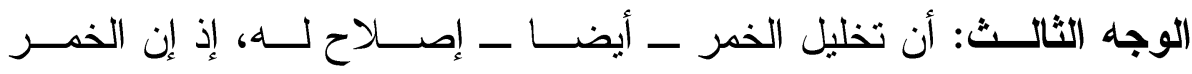

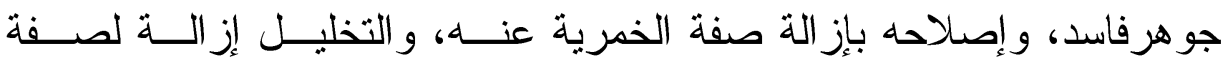
الخمرية، ومن ثم فهو إصلاح له، وهو كدبغ الجلد، فإن عين الجلد نجس، ولهذا لايجوز بيعه، ولو كانت النجاسة لما اتصل به من الاســومات لجــوز بيعـهـ

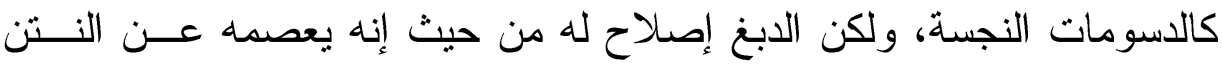
و الفساد، ومن ثم فتخليل الخمر جائز شرعاً كدبخ الجلد (328).

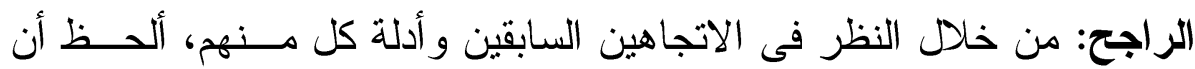
الاتجاه الأقرب للقبول هو ما انتهى إليه أصحاب الاتجاه الأول، الذى ذهب الإن إلى

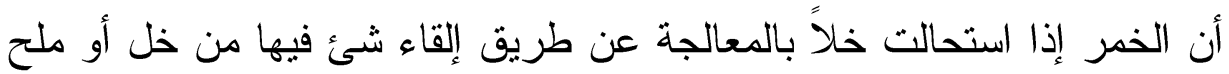

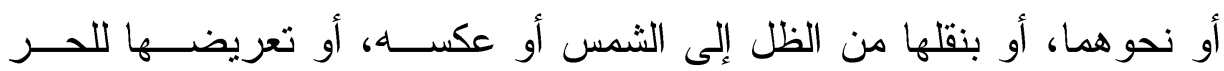


و الريح، فإنها تصيرطاهرة، يحل أكلها و الانتفاع بها، و إنما كان هذا الاتجاه هو

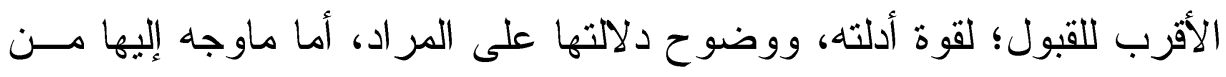
اعتز اضات، فقد نم الاجابة عليها.

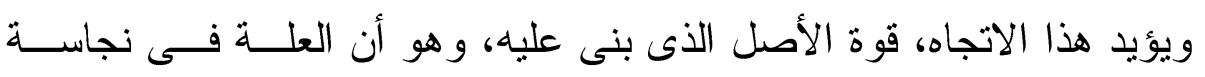

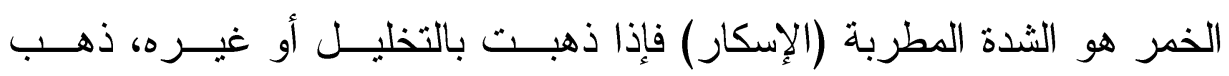
التنجيس، فالتحريم و النجاسة يدور ان مع العلة وجوداً و وعدماً.

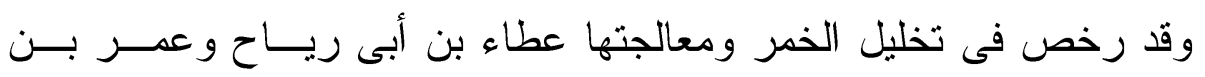
العزيز، رضى الله عنهما (329).

أما الاتجاه الثانى: فقد سبق بيان ضعفه، والإجابة عن أدلته بما يكفى إن شاء الله تعالى.

\section{الفرع الثالث}

الاتتفاع بالخمر المستحالة إلى طاهرة فى الفقه الإسلامى

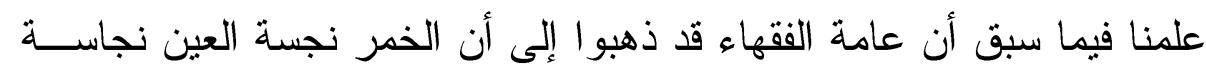

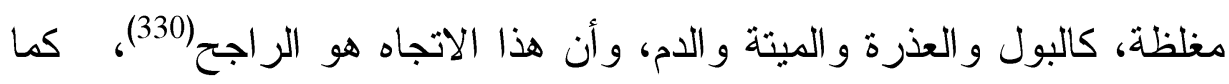

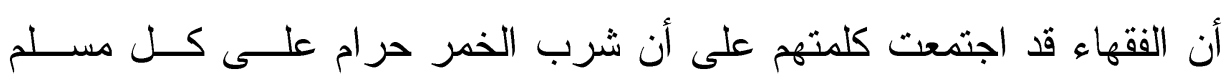
ومسلمة، وأن من شربها يستحق العقوبة المقررة لهذه الجريمة (331). 
وبناء على ذلك: فإن الخمر يحرم استخدامها فى أغراض الأكل والشرب إلا

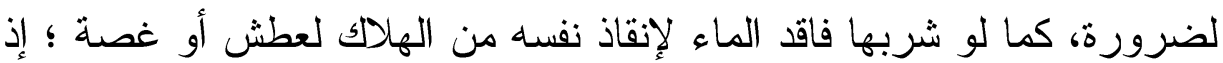
الضرورات تبيح المحظورات (332)، بيد أن الضرورة تقدر بقدر ها (333).

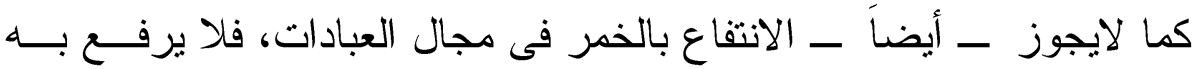

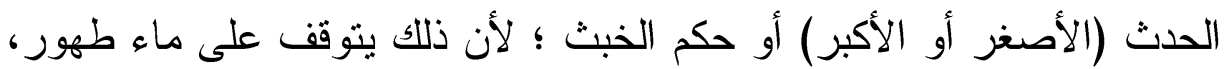

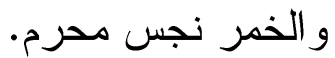

أما الانتفاع بالخمر فى الأغراض الأخرى، فقد ذهب جمهور الفقهاء إلى أنه

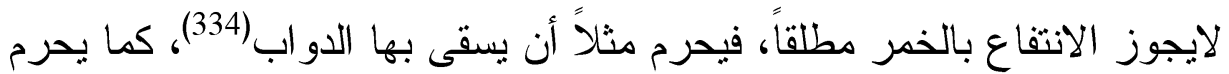

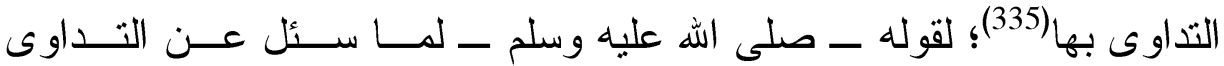
بالخمر ،قال:" إنه ليس بدو اء ولكنه داء "(336).

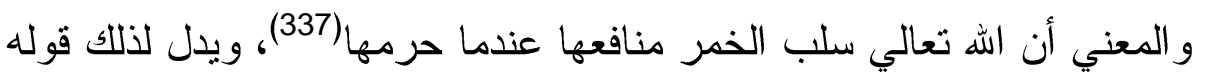

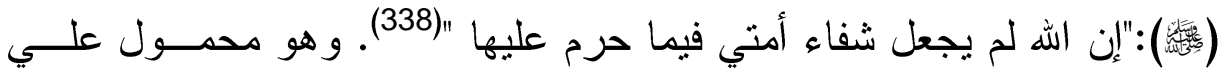

(332) الأشباه و النظائر لابن نجيم ص 85، الأشباه و النظائر للسيوطى ص 843 84.

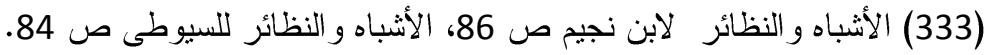

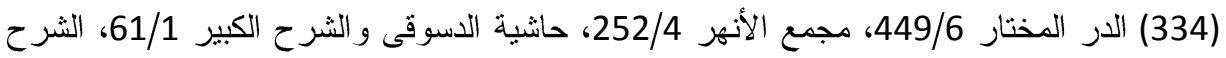
الصغير 17/1، المجموع 51/9، كثاف القناع 116/6.

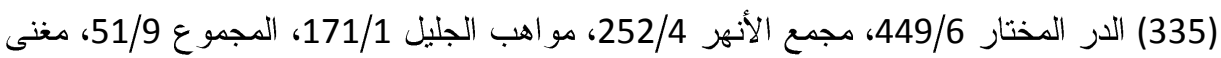

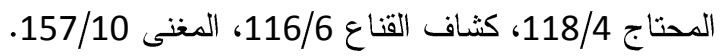

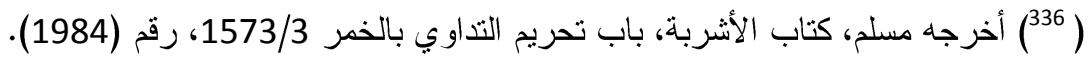

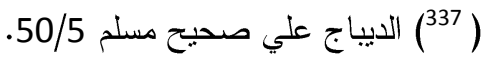

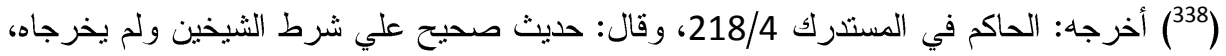

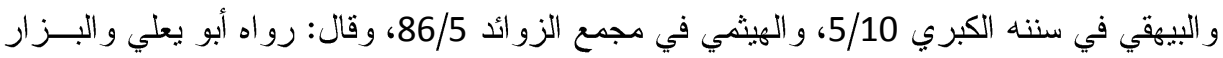

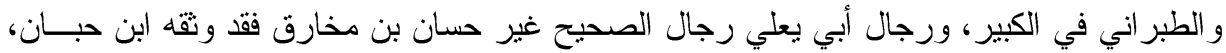
و ابن حجر في فتح الباري 339/1 - ـو أورده القسطلاني في إرشاد الساري 300/1 300، و المناوي فــي

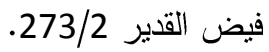
doi: $10.12816 / 0004230$ 


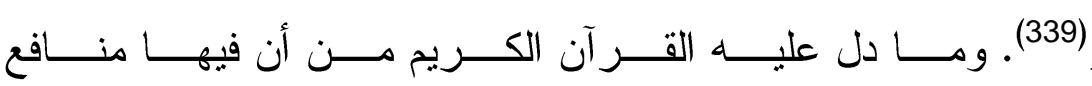

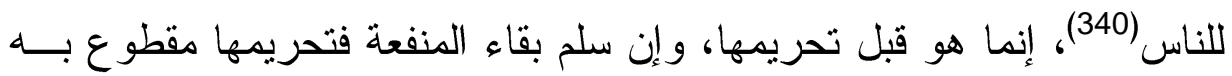

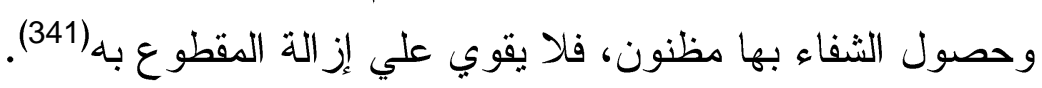

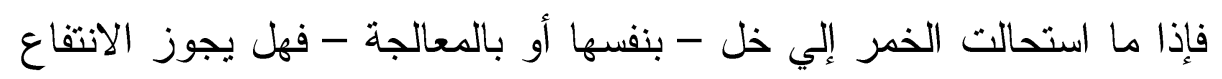

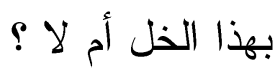

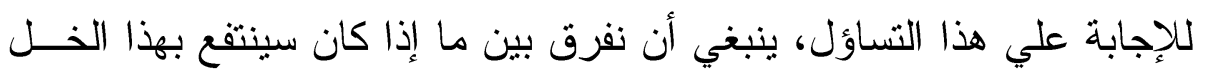
في العادات من أكل أو شرب أو التذاوي به أو نحو ذلك أم في العبادات.

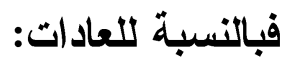

فإذا كان الخمر قد استحال إلي هذا الخل بنفسه، فإنه يجوز الانتفاع بهذا الخل

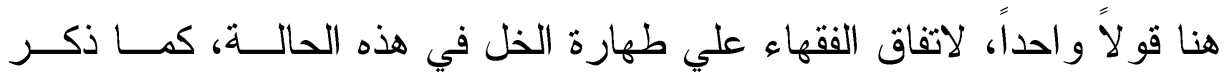

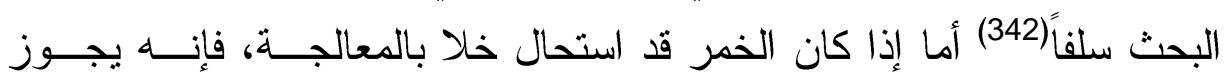

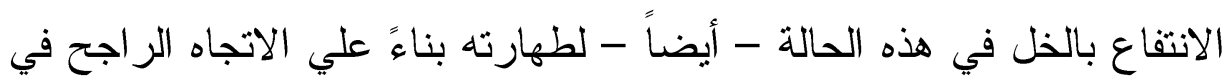

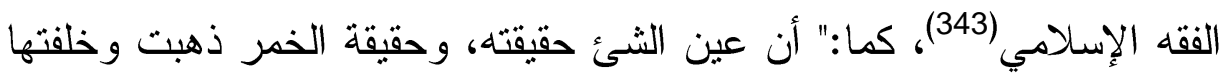
أخري، و هي الخل، فتطهر"(344) ومن ثم يجوز الانتفاع بها في العادات.

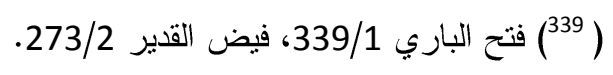

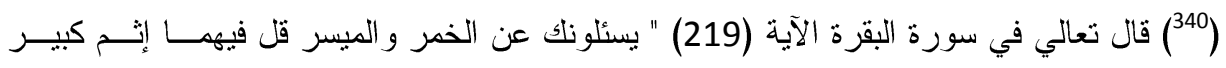
ومنافع للناس و إثمهما أكبر من نفعهما...... ".

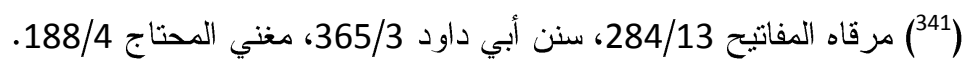

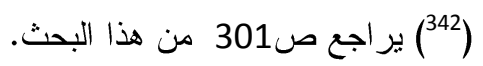

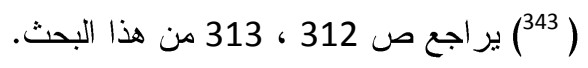

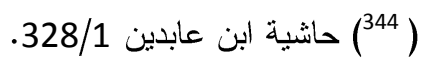


وقد ذكرت كتب السنة، أن الصحابة رضوان الله عليهم لم يجدوا حرجاً فـي

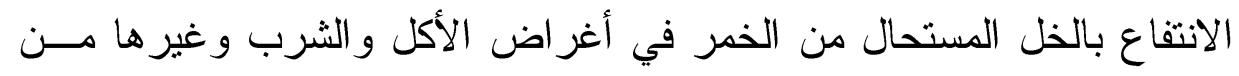
أمور العادات ومن ذلك:

[أ] ما رو اه: المسربل العبدي عن أمه، قالت: سألت أم المؤمنين عائشة ــ الماد

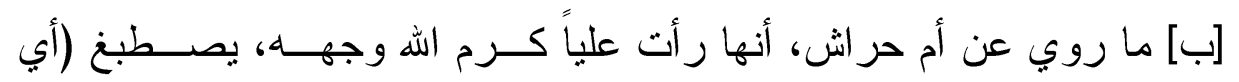

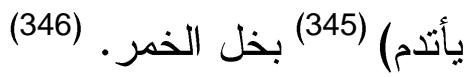

[ج] ما روي عن عبد الله بن نافع عن أبيه عن ابن عمر رضي الله عنهـــا،

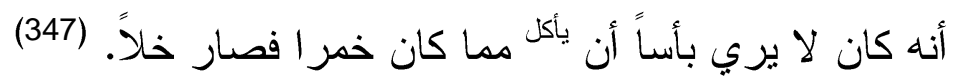

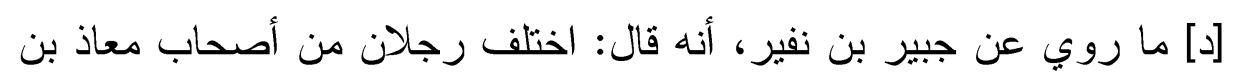

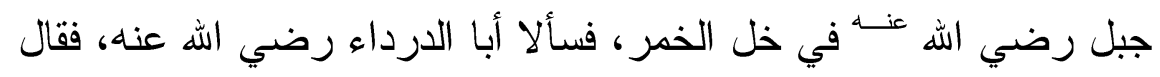

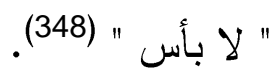

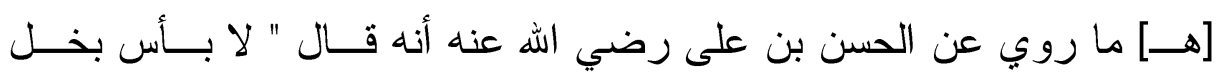
الخمر " (349).

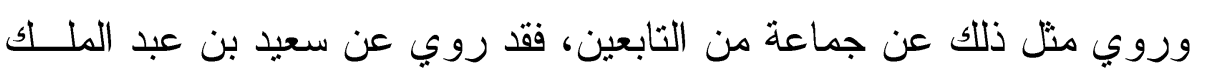
أنه قال: رأيت سعيد بن جبير يصطبغ بخل الخمر. (350) وروي عن ابن سيرين، أنه كان لا يري بأسا بخل الخمر . (351)

$$
\begin{aligned}
& \text { (345) لسان العرب 56/6، 437/8. }
\end{aligned}
$$

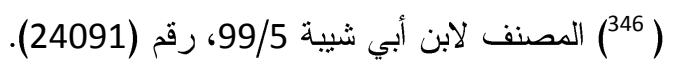

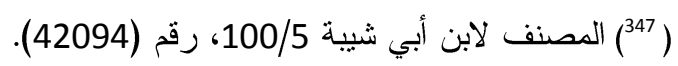

$$
\begin{aligned}
& \text { (248) المصنف لابن أبي شيبة 100/5، رقم (24092). }
\end{aligned}
$$

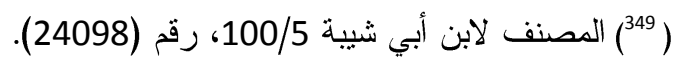

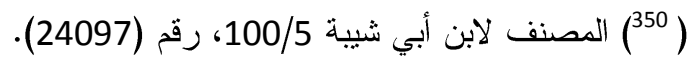

$$
\begin{aligned}
& \text { (314) المصنف لابن أبي شيية 100/5، رقم (24096) رمث (2006). }
\end{aligned}
$$


بيد أنه لابد عند الحكم بجواز الانتفاع بالخل المستحال من الخمر في أغر اض ها

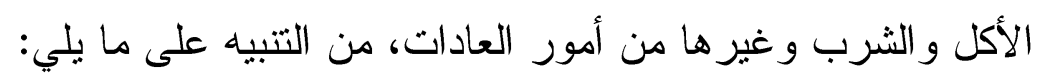

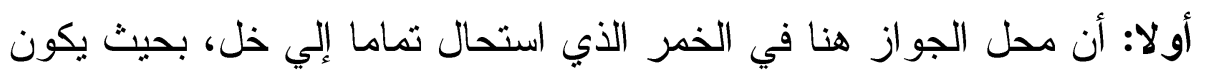

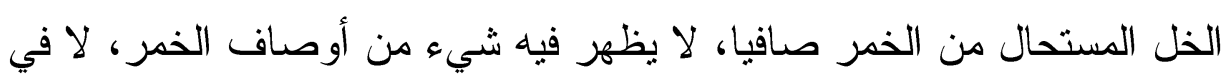
لونه و لا طعمه و لا ر ائحته.

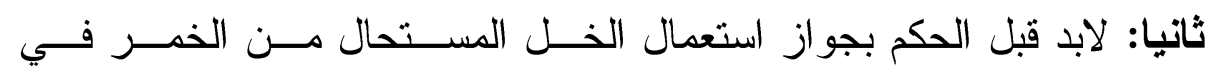

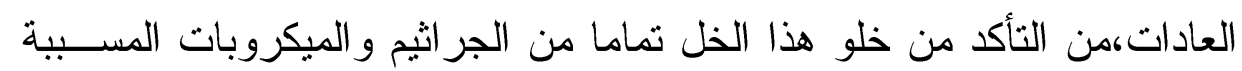

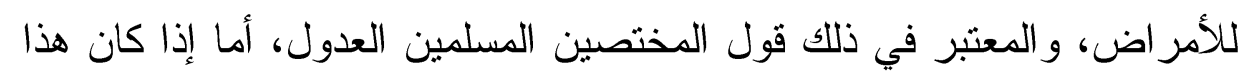

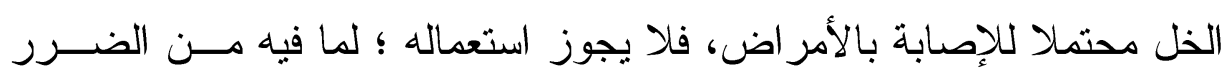

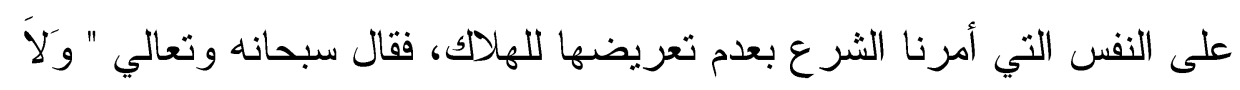

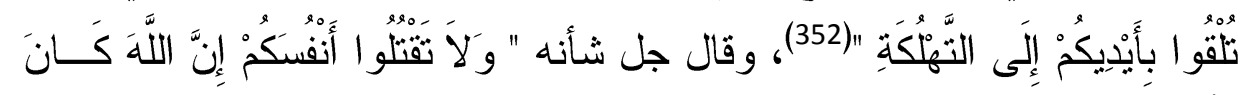

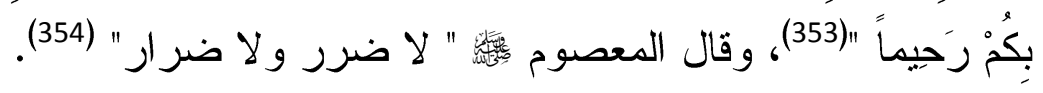

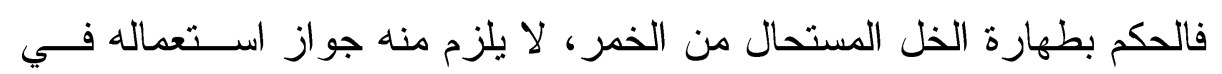

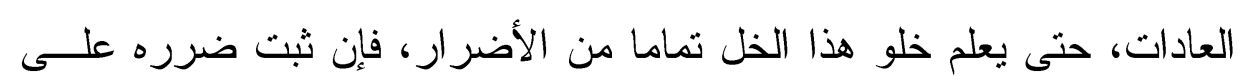

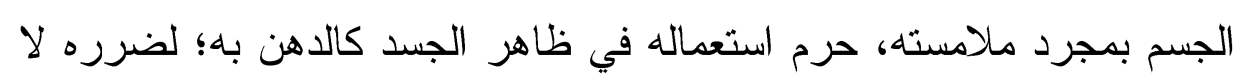

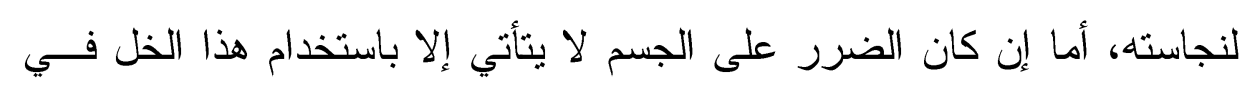

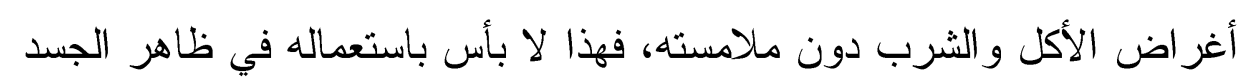


لأن ما يصلح لاستخدامه للجسم من الخارج، قد لا يصلح لتتاوله داخل الجســ

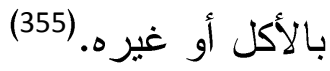
وإن كان الضرر سيأتي من استعمال الخل المستحال من الخمر في العـادات

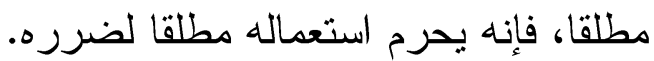

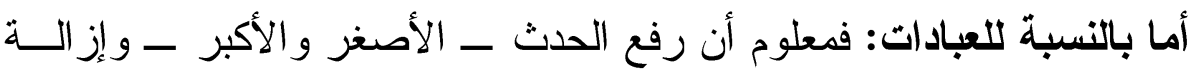
الخبث، لا يكون الا بالماء المطلق أو الطهور (356)، والخل عموما، مائع أو ماء الاء

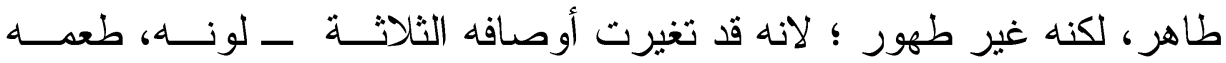
رائحته ــ عن أوصاف الماء المطلق، ومن ثم فلا يستعمل في العبادات مطلقا.

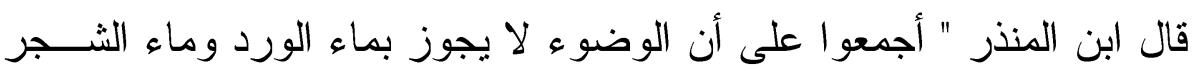
وماء العصفر (357)، و لا يجوز الا بماء مطلق يقع عليه اسم الماء ". (358)

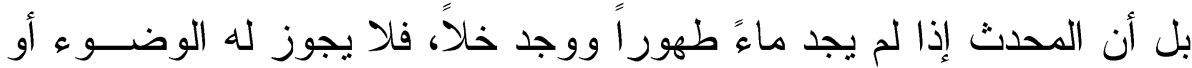
الغسل منه؛ لأنه فاقد للماء الطهور، ومن ثم فينتقل إلي التيمم، إذا وجد الصعيد الطاهر، فإذا لم يجد الصعيد الطاهر، فإنه لا يستعمل الخل أيضاً، ويكون فاقداً للطهورين، فتجري عليه أحكام فاقد الطهورين.

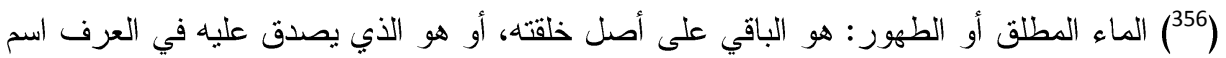

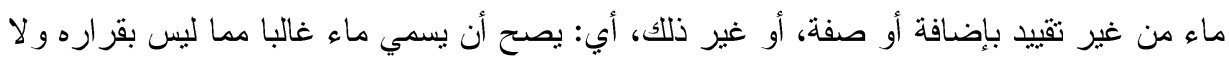

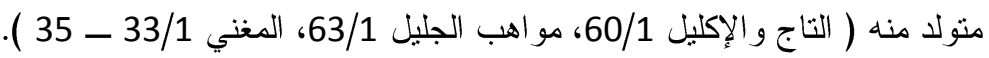
( (357) العصفر: نبات بأرض العرب (لسان العرب، مادة (عصفر) 581/4 ).

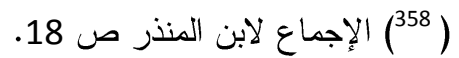




\section{المطلب الثاني \\ ما يستحال من الميتة إلي طاهر للاتفاع به في الفقه الإسلامي}

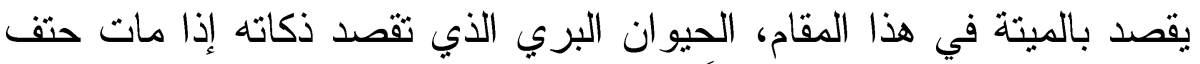

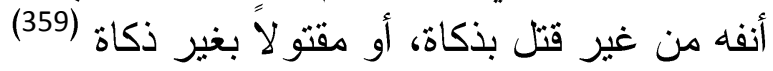

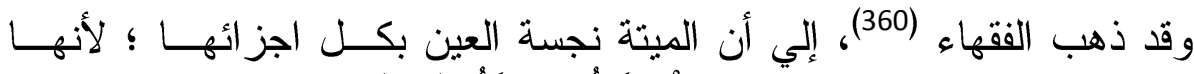

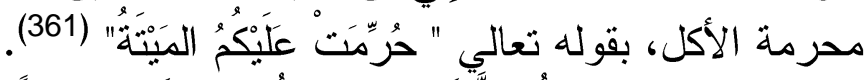

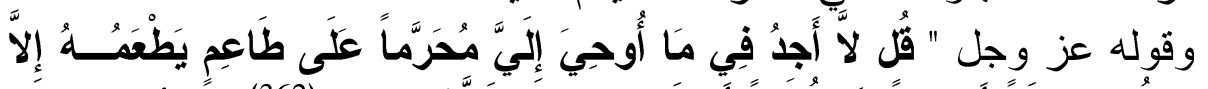

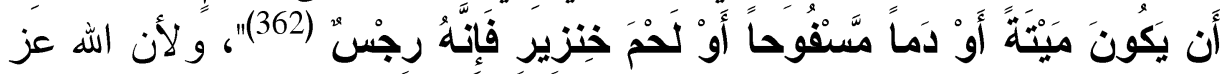

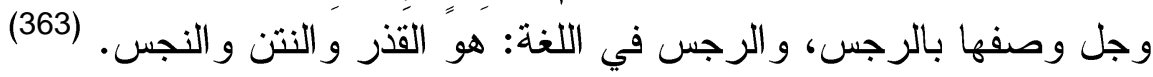

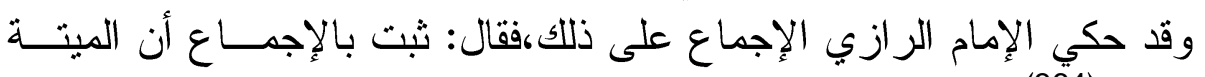
نجسة " (364). هذا: وقد بحث الفقهاء موضوع ما يستحال من الميتة للانتفاع به في مســائل

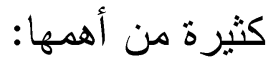
[أ] استخدام إنفحة (365) الميتة في تحضير الجبن. [ب] استحالة جلد الميتة بالدباغ.

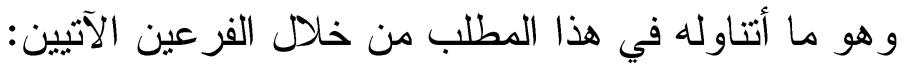

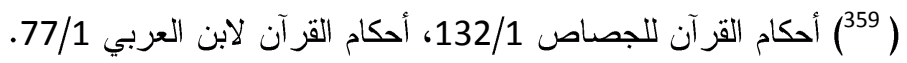

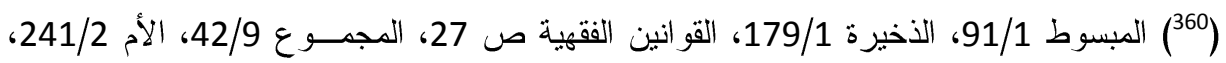

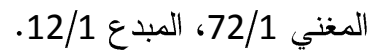
(361) بعض الآية (3) من سورة المائدة.

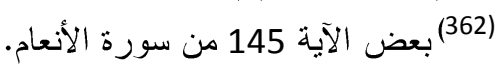

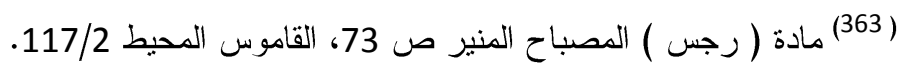

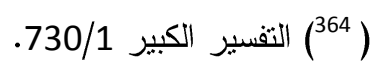
(365) الإنفحة ( بكر الهمزة وقد تثدد الحاء وقد تكسر الفاء ) و المنفحة و البنفحة شيء واحئ احد يستخرج من بطن الجدي الراضع أصفر فيعصر في صوفه فيخل به الجين ( حاشية ابن عابدين 206/1 ). 317 
الفرع الأول: استخدام إنفحة الميتة في تحضير الجبن في الفقه الإسلامي. الفرع الثاني: استحالة جلد الميتة بالدباغ، وما يترتب عليه من آثار في الفقه

\section{القرع الأول}

\section{استخدام إنفحة الميتة في تحضير الجبن في الفقه الإسلامي}

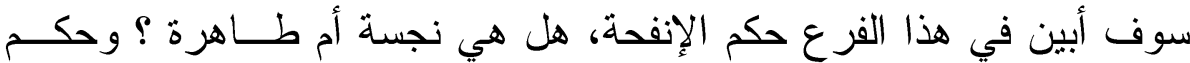
تتاول الجبن المصنوع بها، وذلك من خلال غصنين كالتالى: الغصن الأول

\section{حكم الإنفحة}

اتفق الفقهاء على أن إنفحة الخنزير نجسة؛لأن ميتته وجميع أجزائه نجسة (366).

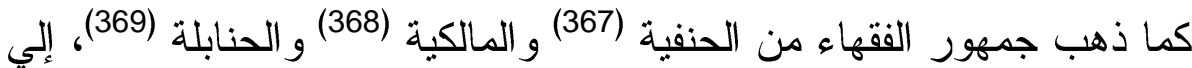

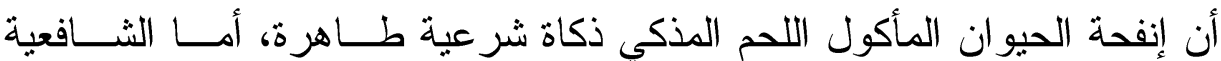

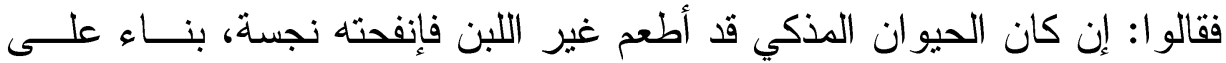
الأصل في المستحيلات في الباطن، بيد أنه يعفى عنها في صناعة الجبن نظر الهرب

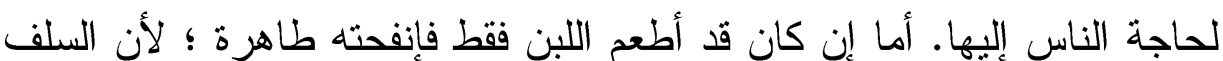
لم بز الو ا يجبنون بها، و لا يمتتعون من أكل الجبن المعمول بها. (370) بيد أن الفقهاء اختلفوا في إنفحة ميتة غير الخنزير، و الحيوان المذكي ذكـــاة غير شرعية، وتمخض عن ذلك ظهور اتجاهين:

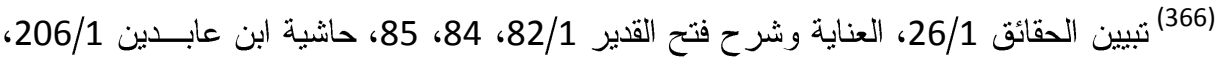

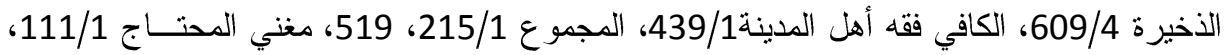
روضة الطالبين 132/1، المغني 73/1.

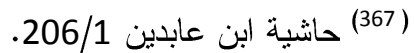

(368) مو اهب الجليل 122/1، شرح الخرشي 85/1، الثرح الكبير 50/1، التاج و الإكليل 120/1/1.

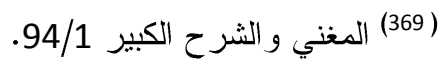

(370) المجموع 570/2، مغني المحتاج 114/1، روضة الطالبين 127/1، حاثية القليوبي 72/1. doi: $10.12816 / 0004230$ 


\section{الاتجاه الأول:}

يري أنصاره أن إنفحة الميتة والحيوان المذكي ذكاة غير شرعية نجسة. إليه ذهب أبو يوسف ومحمد من الحنفية (371).

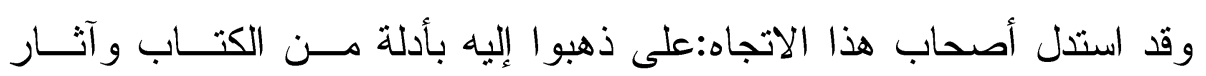

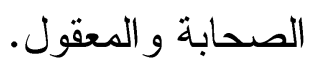
أما الكتاب:

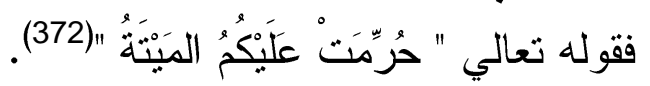

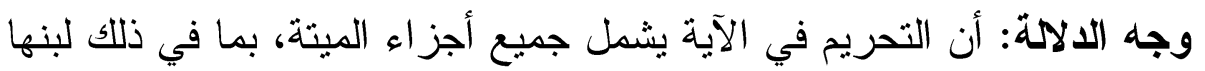

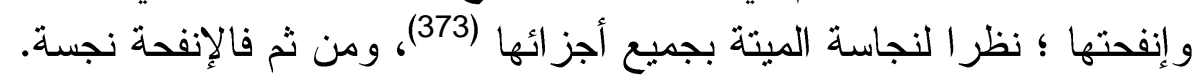
أما آثار الصحابة: فمنها:

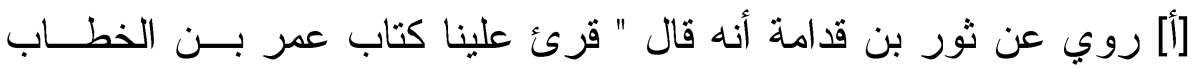

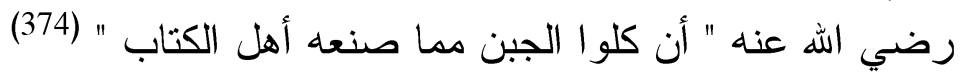

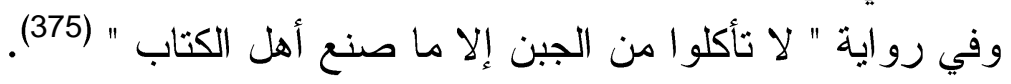

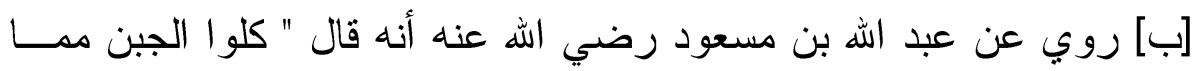
صنع المسلمون و أهل الكتاب " (376).

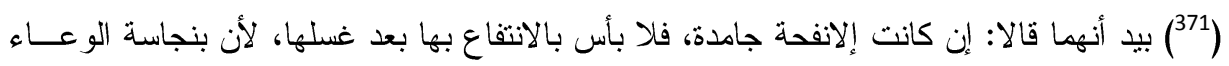

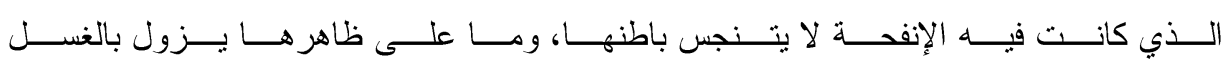

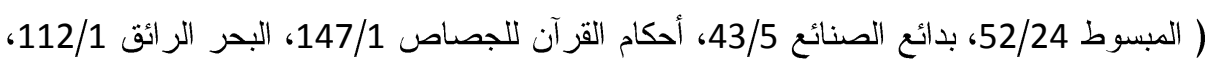

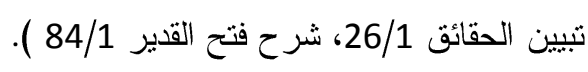

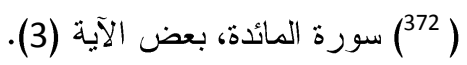

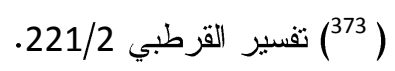

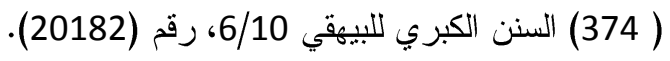

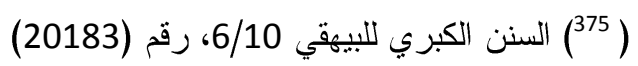

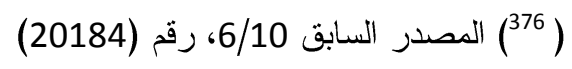


[ج] سئل عبد الله بن عمر رضي الله عنهما عن الجبن، فقال " كل ما صــنع المسلمون و أهل الكتاب " (377)

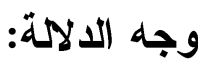

أن حل أكل الجبن مقيد بأن يكون مصنو عا بمعرفة المسلمين و أهل الكتاب في

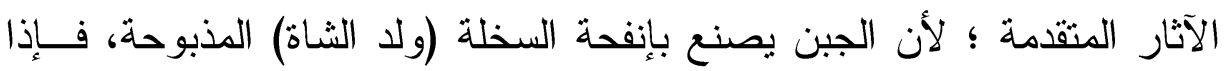

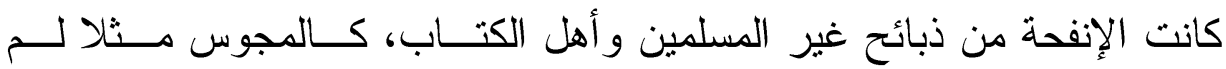

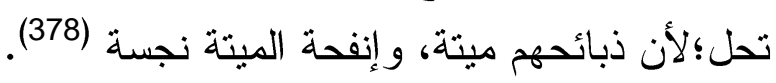

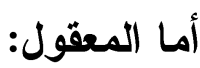

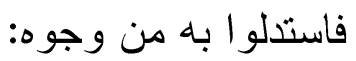
الوجه الأول: أن الإنفحة مائع في وعاء نجس، فكان فان نجسا، كما لو حلب في و عاء نجس.

\section{نوقش هذا الاستدلال من وجهين:}

الأول: أن موضع الخلقة لا ينجس بالمجاورة لما خلق فيه، و الدليل على ذلك:

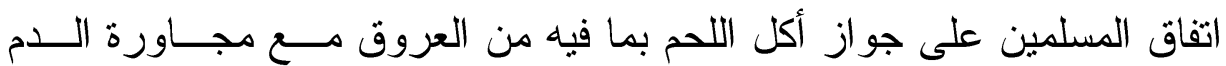
لدو اخلها من غير تطهير و لا غسل لذلك. الثاني: أن الله عز وجل أخبرنا بخروج اللبن من بين فرث ودمه، وهما نجسان

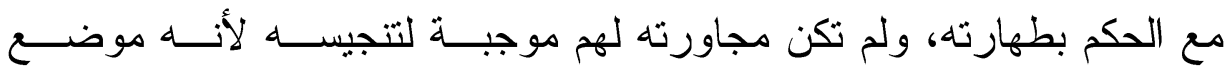
الخلقة. (380)

الوجه الثاني: أن هذا المائع (الإنفحة) لو أصاب الميتة بعد فصله عنها لكان نجسا، فكذلك بعد فصله. (381)

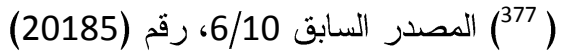

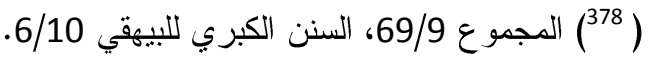

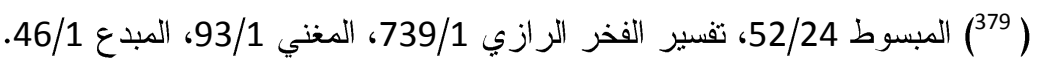

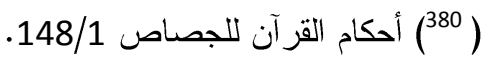

$$
\begin{aligned}
& \text { 93/1. } \\
& \text { doi: } 10.12816 / 0004230
\end{aligned}
$$




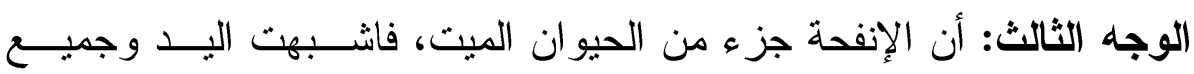
أجز اء هذا الحيوان في النجاسة. (382)

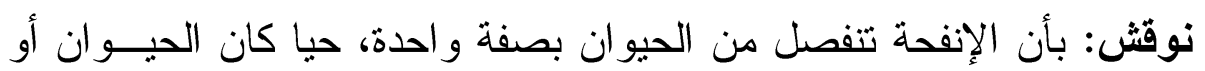

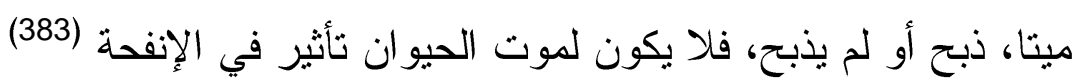

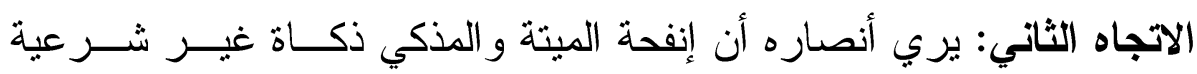

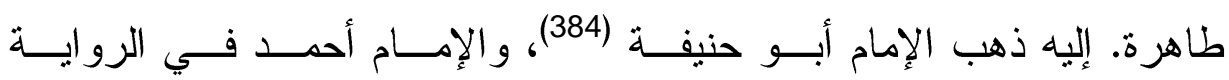
الثانية عنه. (385)

وقد استدل أصحاب هذا الاتجاه على ما ذهبوا إليه بأدلة من الســنة وآثــار

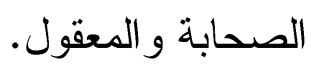

\section{أما السنة: فأحاديث كثيرة منها:}

[أ] روي شريك عن جابر الجعفي عن عكرمة عن ابــن عبــاس رضـــي الله

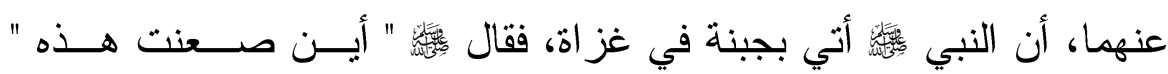

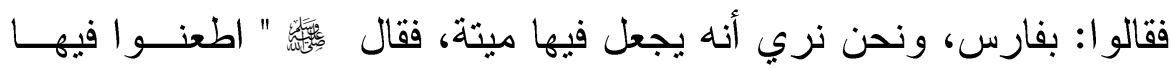
السكين و اذكرو السم الله عليها وكلو ا " (386).

$$
\begin{aligned}
& \text { (570/2. } \\
& \text { (52/24. }
\end{aligned}
$$

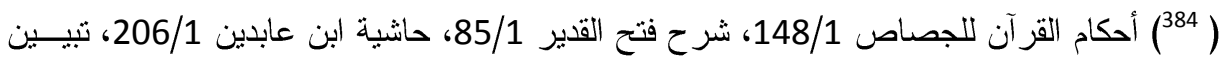

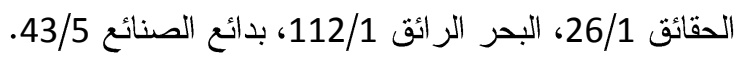

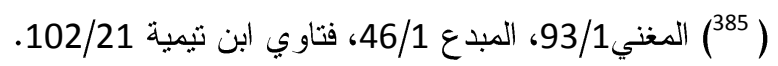

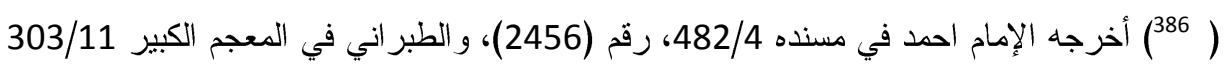

$$
\text { | رقم (11835) و الهيثمي في مجمع الزو ائد 55/5، رقم (8025) (2025) }
$$


وجه الاستدلال: أن النبي :

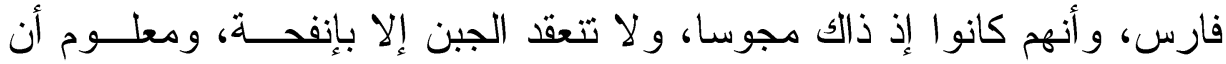
ذبائح المجوس ميتة، فتبت بذلك أن إنفحة الميتة طاهرة (387).

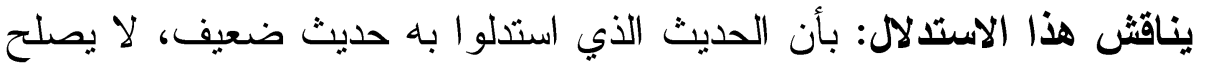

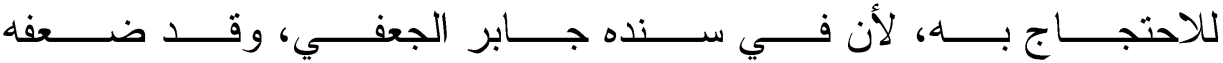

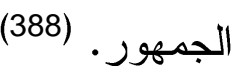

يجاب عنه: بأن جابر الجعفي قد وثقه بعض علماء الحديث، فقد قال الهيثمي

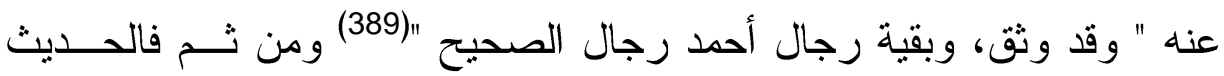
صالح للاحتجاج به. [ب] روي عن ميمونة زوج النبي : الجبن، فقال " ضع السكين و اذكر اسم الله عليه وكل " (390)

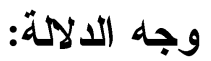

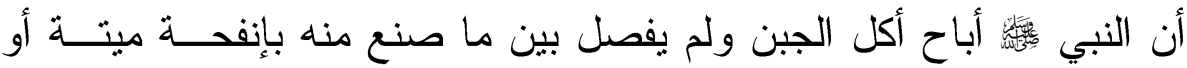
غير ها، فثبت بذلك بأن الإنفحة جميعا طاهرة " (391). يناقش: بأن الحديث الذي استدلو ا به حديث ضعيف لان لإنوم به به حجة، لأن في سنده أحمد بن الفرج الحجازي، وقد ضعفه محمد بن عوف و ابن عدي (392).

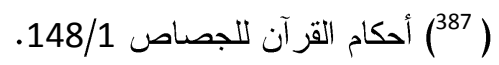

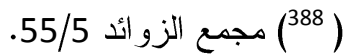
(389 (389) (المصدر السابق، نفس الموضع.

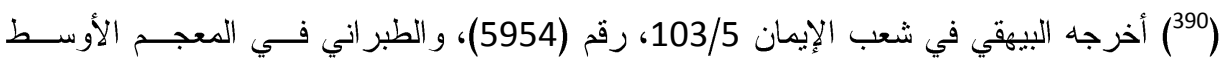

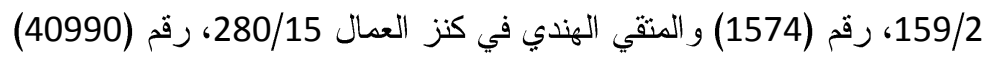

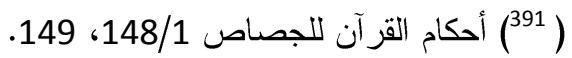

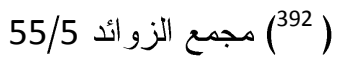


يجاب عنه: بأن أحمد بن الفرج الحجازي قد وتقه ابن أبي حاتم، فضلا عـنـ أن بقية رجال الحديث ثقات " (393)، ومن ثم فالحديث يصلح للاحتجاج بهان.

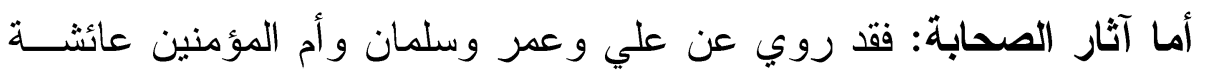

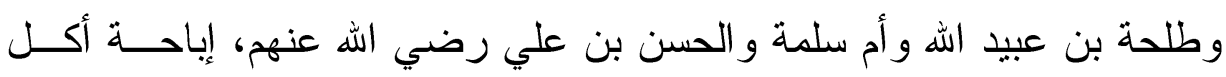

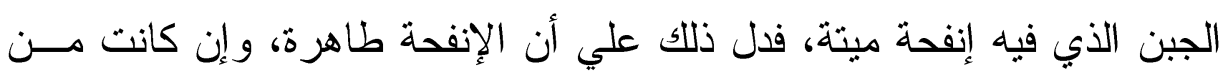
ميتة(394).

أما المعقول: فاستدلو ا به فقالو ا: إن إنفحة الميتة كإنفحة المذكاة ذكاة شرعية،

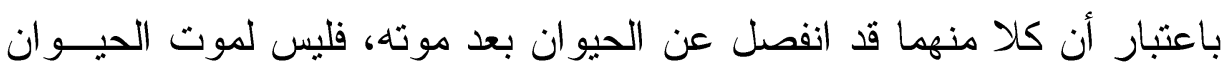
تأثير في الإنفحة(395).

الر اجح: بعد استعر اض ما استدل به للاتجاهين في حكم إنفحة الميتة و المذكي

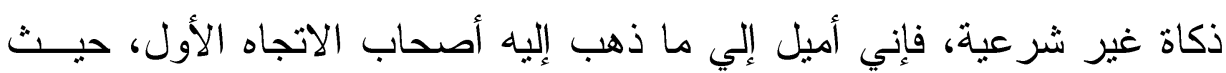

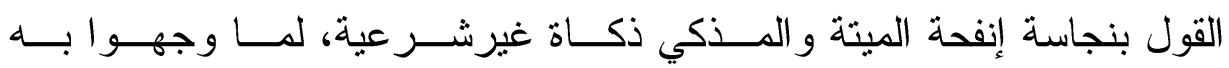

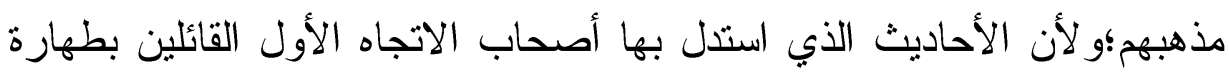

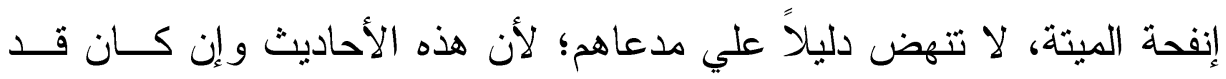

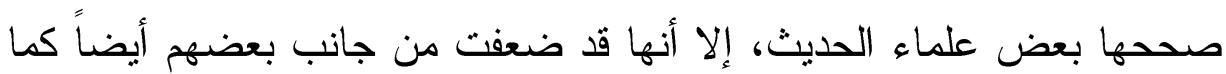

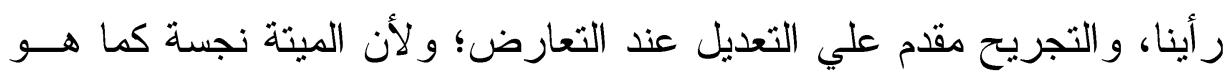
معلوم وهذا الحكم بشمل جميع أجزائها، بما في ذلك إنفحتها. 


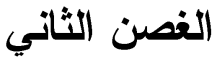 \\ حكم تناول الجبن المصنوع بالإنفحة}

اتفق الفقهاء علي أن الجبن المصنوع بإنفحة حيوان مذكي ذكاة شرعية،طاهر لإلهر يحل أكله (396).

بيد أنهم اختلفوا في حكم تتاول الجبن المصنوع بإنفحة الميتـــة أو الحيــوان المذكي ذكاة غير شرعية، وتبلور عن ذلك ظهور اتجاهين: الاتجاه الأول:

يري أنصاره أن الجبن المصنوع بإنفحة الميتة و الحيوان المذكي ذكاة غيــر

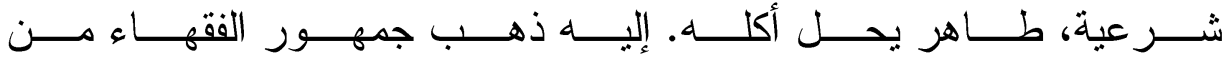

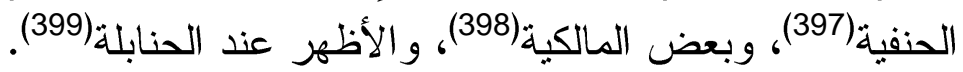

وقد استدل أصحاب هذا الاتجاه علي ما ذهبو الإليه: بالسنة و آثار الصحابة الصنابة

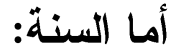

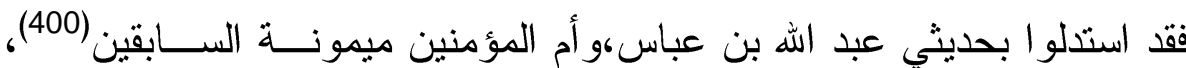
اللذين استدل بهما القائلون بطهارة إنفحة الميتة، وقالو إنها إنه مادامت هذه الإنفحة

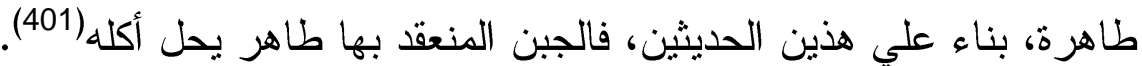

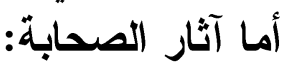
فقد استدلو ا بما استدل به القائلون بطهارة إنفحة الميتة، من أنه قد روي عـن

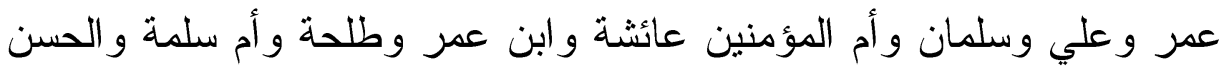

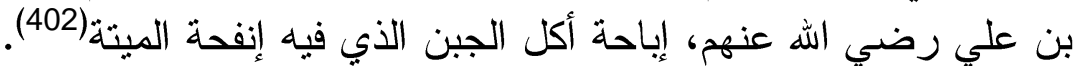

(50/1) بدائع الصنائع 43/5، شرح الخرشي 85/1، مواهب الجليل 122/1، الثرح الكبير للــدردير $.50 / 1$ (206/1 2067، أحكام القر آن للجصاص 148/1 148/1، ماثية ابن عابدين 149.

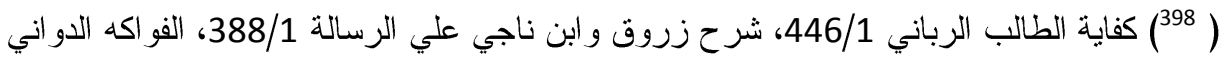
$.404 / 1$

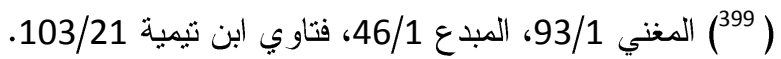
(400) ير اجع ص 119، 120 منلق هذا البحث. (401 (أحكام ارآن للجصاص 148/1، 140، 149.

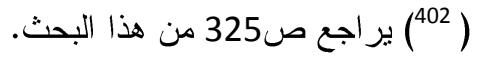


واستدلوا أيضاً: بما روي أن امر أة من هذذان سألت أم المـــؤمنين أم ســلمة

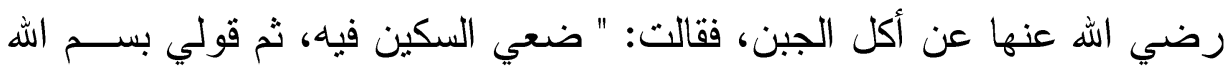
عليه وكلي "(403).

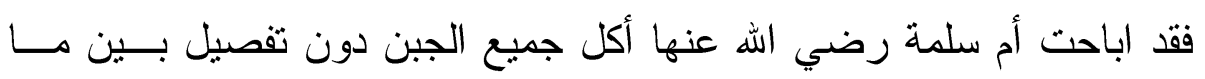

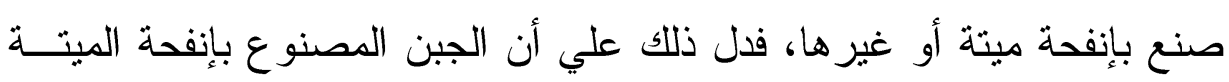
طاهر يحل أكله.

الاتجاه الثاني: يري أنصـاره أن الجبن المصنوع بإنفحة الميتــة والحيـــوان المذكي ذكاة غير شرعية، نجس لا يحل أكله.

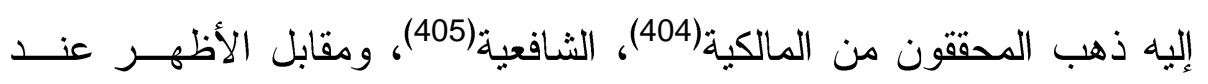
الحنابلة، وهو الرواية الثانية عن الإمام أحمد (406).

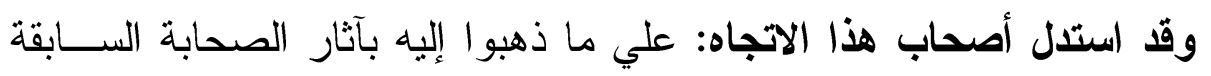

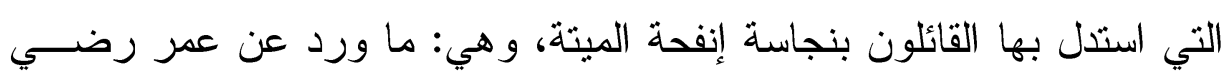

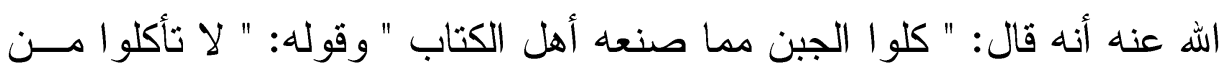
الجبن إلا ما صنعه أهل الكتاب " وقول عبد الله بن مسعود رضي الله عنــه: "

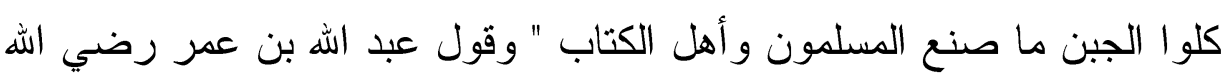
عنهما لما سئل عن الجبن: " كل ما صنع المسلمون وأهل الكتاب "(407).

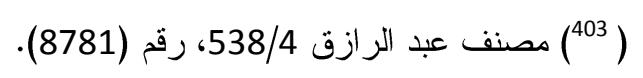

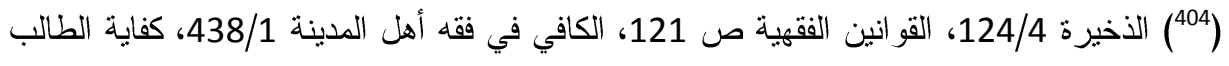

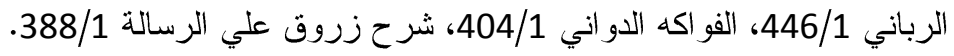

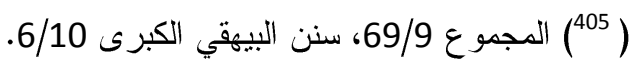

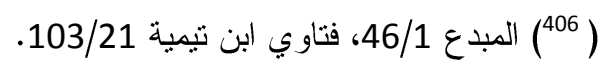
(407) ير اجع ص 321 ، 322 من هذا البحث. 


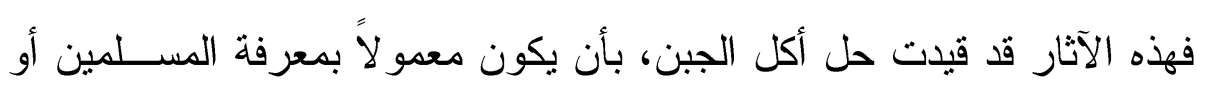
أهل الكتاب، وذلك لأن الجبن يصنع بإنفحة ما يذبح من صغار البهائم كما هو

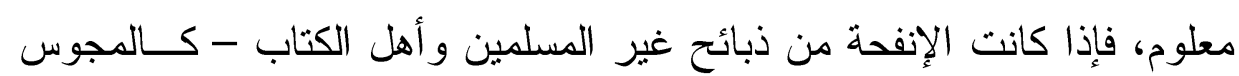

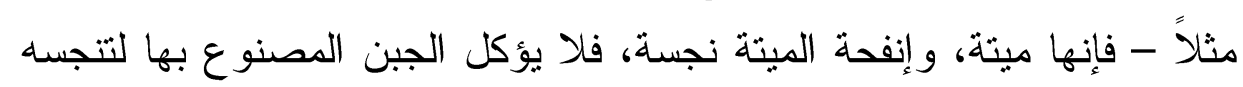

$$
\text { بهاب(408). }
$$

كما استدلوا أيضاً: بما روي عن عبد الله بن عمر رضي اله عنهما، أنه سئل

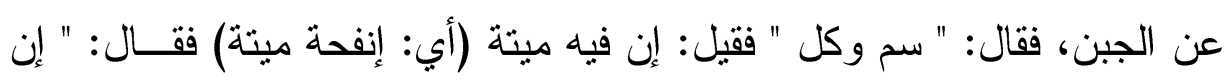
علمت أن فيه ميتة فلا تأكله "(409).

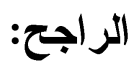

أر اني أميل إلي ما ذهب إليه أصحاب الاتجاه الأول، من القول بجواز تتاول

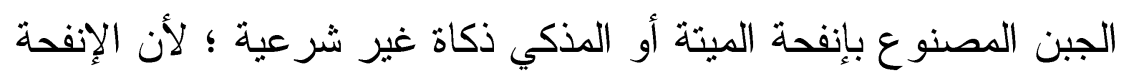

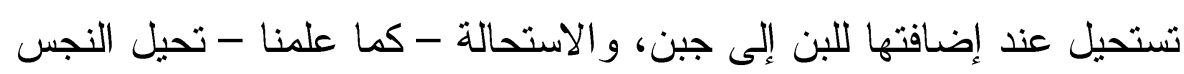

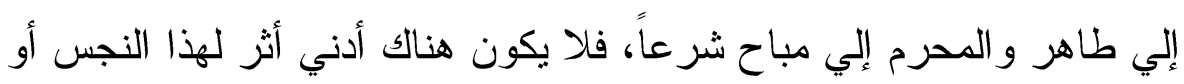

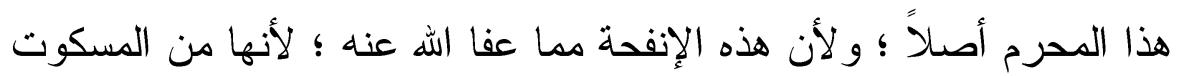

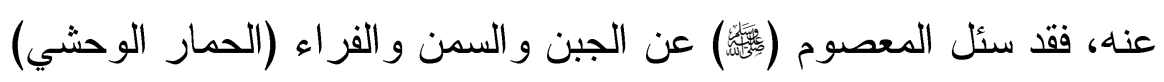

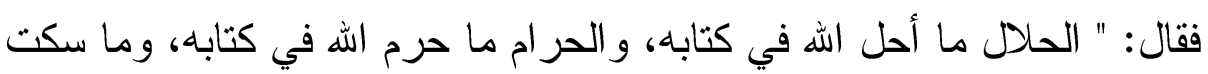
عنه فهو عفو "(410).

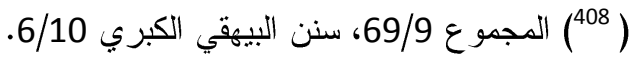

$$
\begin{aligned}
& \text { (409) المصدر السابق 7/10، رقم (20186). }
\end{aligned}
$$

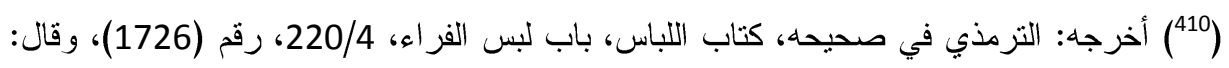

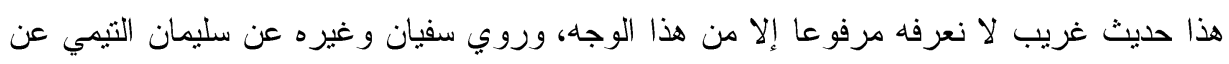

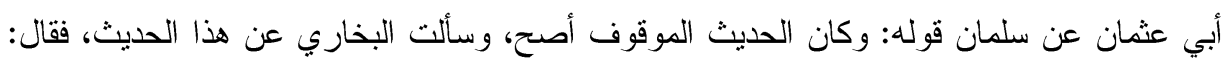

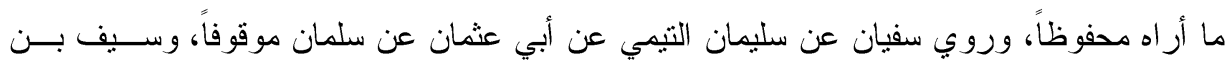

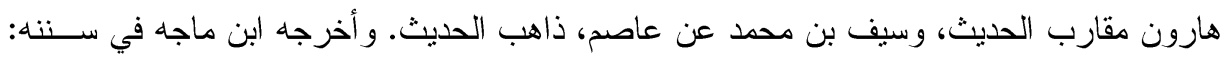
doi: 10.12816/0004230 
وقد صدرت نوصية عن الندوة الفقهية الطبية الثامنة للمنظمة الإسلامبة

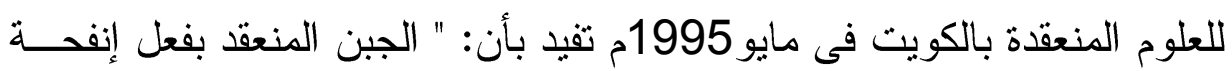

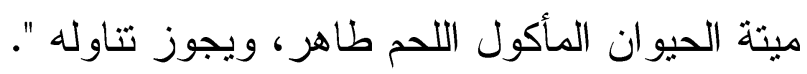
الفرع الثاني

استحالة جلد الميتة بالاباغ وما يترتب عليه من آثار في الفقه الإسلامي

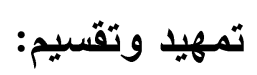

الدبغ في اللغة: مصدر (دبغ) يقال: دبغ الجلد دبغاً ودباغة، أي: عالجه بمــا يزيل نتنه وفساده.

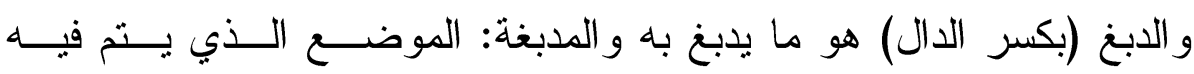
الابغ (411).

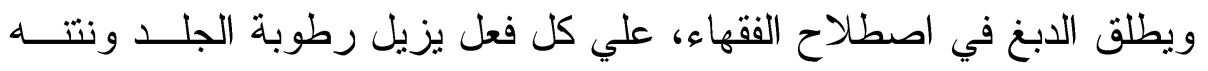

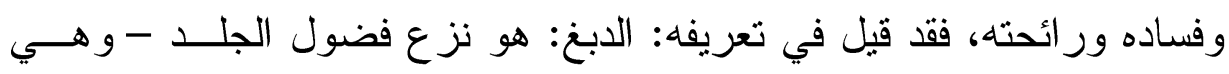

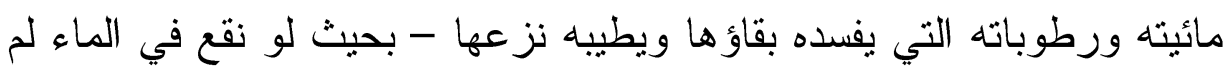
يعد إليه النتن و الفساد(412). وقيل في تعريفه أيضاً: " هو ما يعصده من النــنـائه و الفساد "(413).

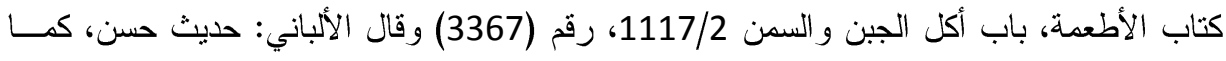

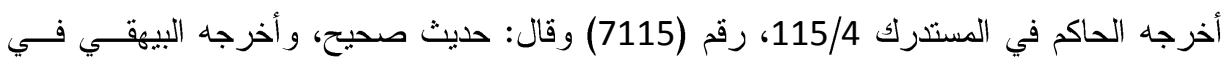

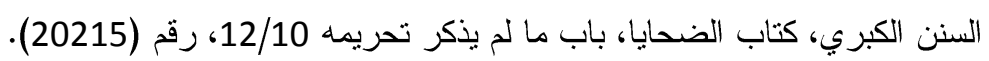

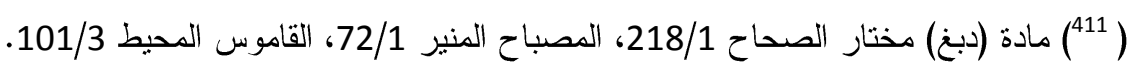

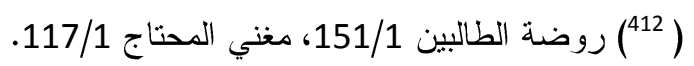

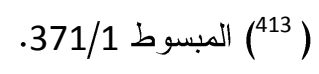


ويصح الدبغ بكل دبغ يزيل الرطوبة وينقي الخبث، ويزيل الريح و النتن مسن

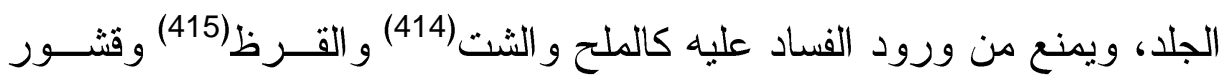

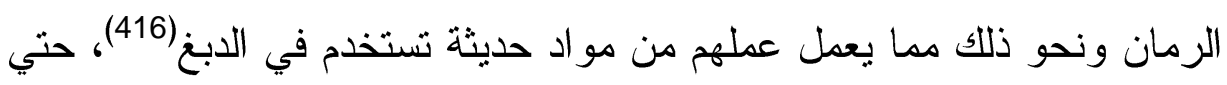
ولو كان نجساً عند جمهور الفقهاء من الحنفية والمالكية والأصح عند الثافعية دئية

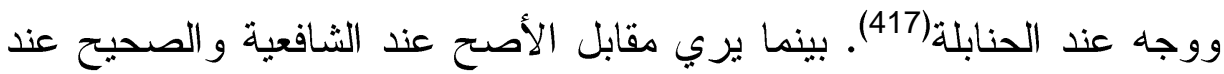

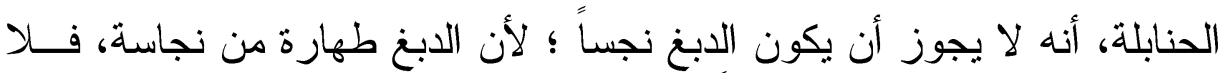
تحصل بنجس (418). و الراجح هو ذهب إليه جمهور الفقهاء ؛ لأن المقصود هو استحالة الجلد إلي

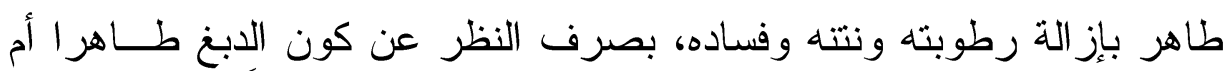
نجساً.

و لا يفتقر الدبخ إلي فعل فاعل، فإن وقع الجلد في مدبغــة فزالــت رطوبتــهـ

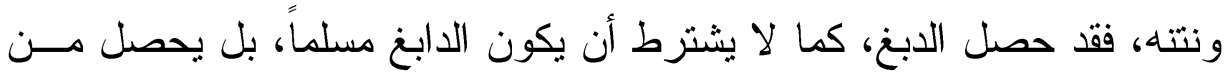

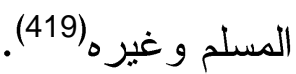

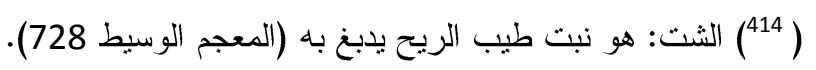

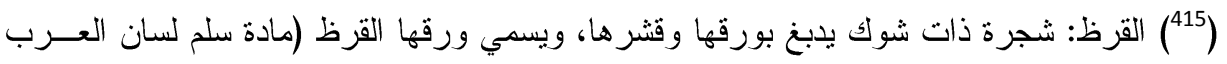
.(289/12

(146) بدائع الصنائع 86/1، شروح الهاية 83/1، حاثية ابن عابـدين 203/1، مواهــب الجليـل

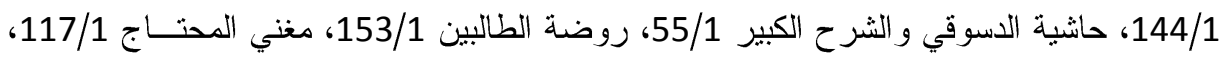

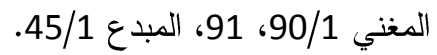

(64/17 حاثية ابن عابدين 203/1، حاثية الدسوقي و الثرح الكبير 55/1، المجموع 225/1 الحاوي الكبير 64/1، المبدع 45/1.

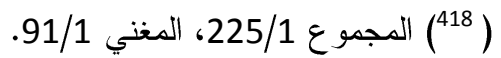
(1919) ير اجع: البدائع، شروح الهداية، حاشية ابن عابدين، مو اهب الجليل، حاشية الدسوفي و الثـــرح الكبير، روضة الطالبين، مغني المحتاج، المغني، المبدع، المصادر السئ، السابقة. doi: $10.12816 / 0004230$ 


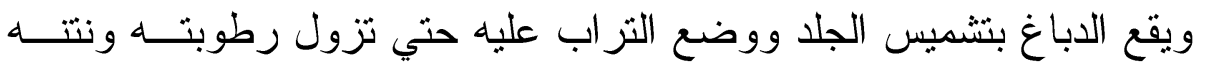

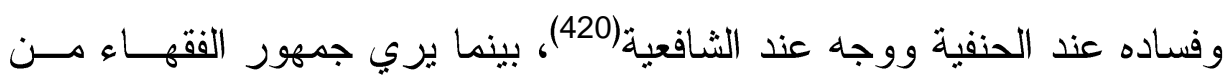

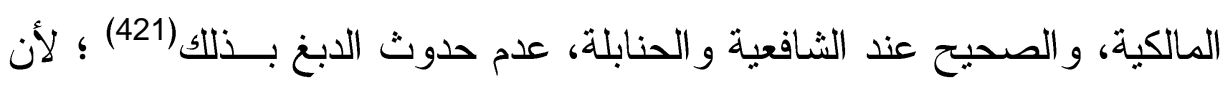
فضلات الجلد لا تزول بذلك، و إنما تتجمد فقط، بدليل أنه لو وقع الجلد في الماء عادت إليه العفونة(422. و الر اجح أنه برجع في ذلك إلي أهل الصنعة (الدباغين) فإن قالو ا بأن للتراب أو التشميس هذا الفعل (الدبخ) حصل بهما، و إلا فلا.

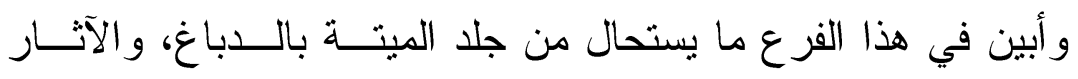
المترتبة علي ذلك في الفقه الإسلامي من خلال غصنين كالتالي: الغصن الأول

\section{ما يستحال من جلود الميتة بالدباغ في الفقه الإسلامي}

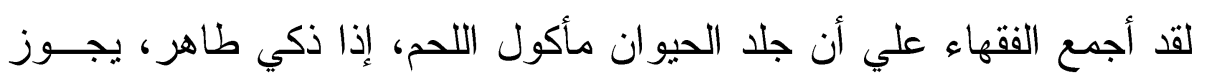
استعماله مطلقاً، دبخ أو لم يدبغ (423).

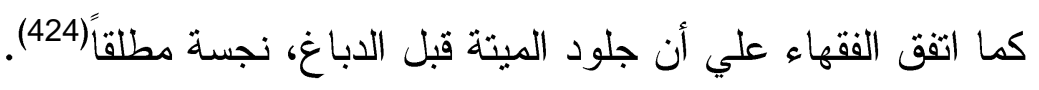

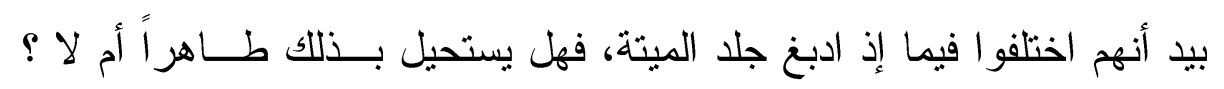
وتبلور عن ذلك ظهور ستة اتجاهات:

$$
\text { (220) شروح الهداية 83/1، المجموع 224/1. }
$$

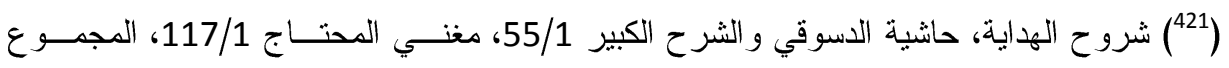

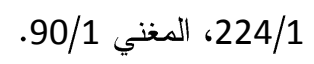

$$
\text { (222) }
$$

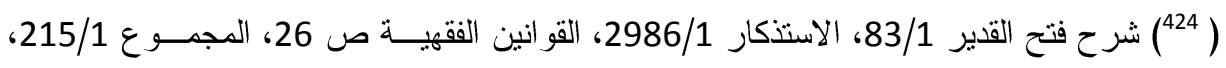


الاتجاه الأول: يري أنصاره أن جميع جلود الميتة تستحيل طاهرة بالدباغ، بما

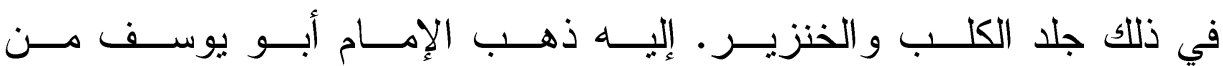

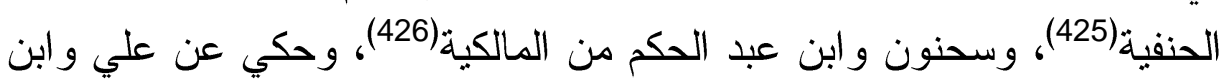
مسعود رضي اله عنهما(427). وقد استدل أصحاب هذا الاتجاه علي ما ذهبوا إليه بأدلة من السنة و المعقول. أما السنة: فأحاديث كثيرة منها:

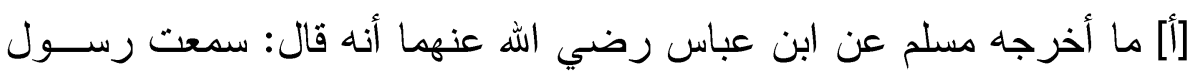

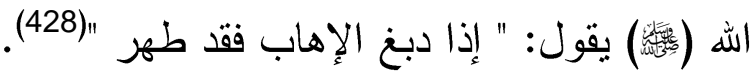

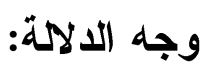

الحديث يدل دلالة و اضحة علي أن الدباغ مطهر لجلد ميتة كل حيوان، وأنـــه يطهر ظاهره وباطنه، فهو عام في جميع الجلود (429).

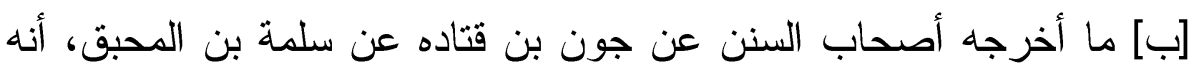

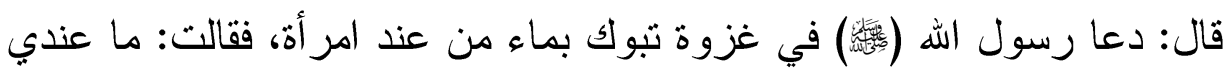

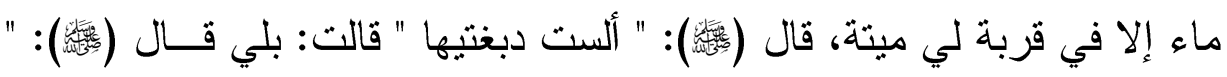
دباغها طهور ها "(430).

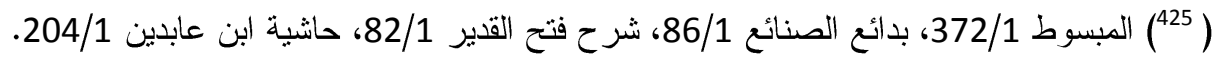

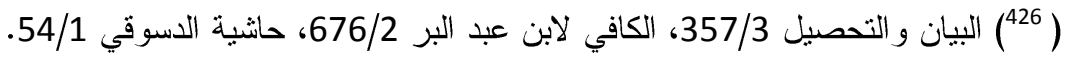

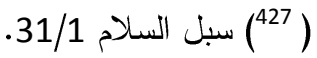
(228) صحيح مسلم، كتاب الطهارة، باب طهارة جلود الميتة بالدباغ 277/1 28/1، رقم (28/1) (366). و الإهاب: هو الجلد قبل أن يدبغ (امصباح المنير 28/1).

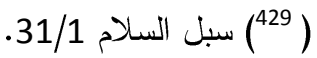

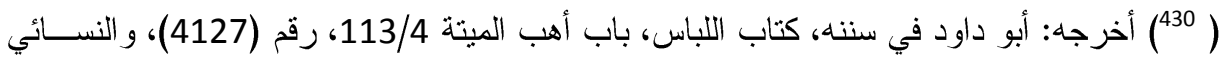

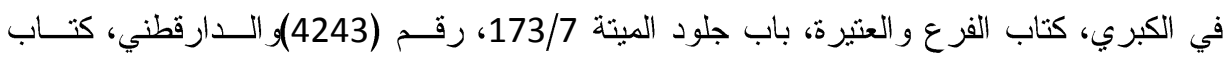

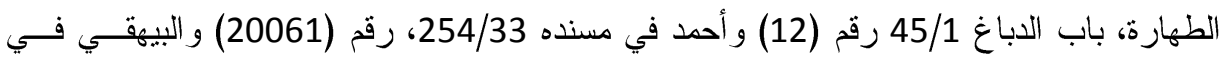

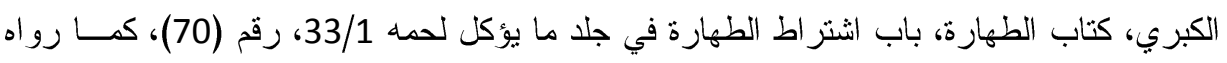
الزيلعي في نصب الراية 117/1، 118، والمقسي في ذخيرة الحفاظ، وقال: في سنده: الجون بـن قتادة وهو مجهول، كما قال أحمد و التزمذي. 


\section{وجه الدلالة:}

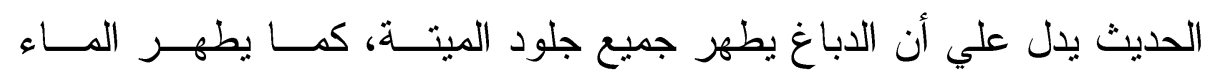

النجاسة.

[ج] ما أخرجه البخاري ومسلم (431) في صحيحيهما عن ابن عباس رضي اله اله

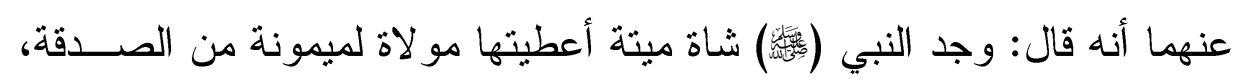

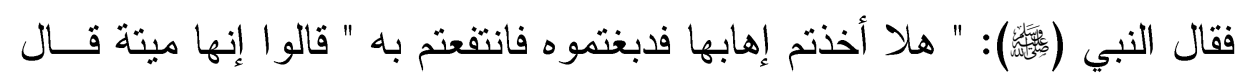

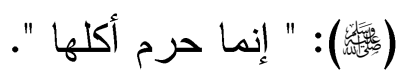

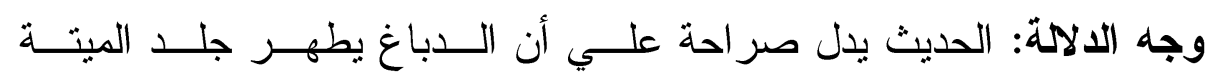
عموما، فيحل الانتفاع به.

\section{نوقش الاستدلال من السنة:}

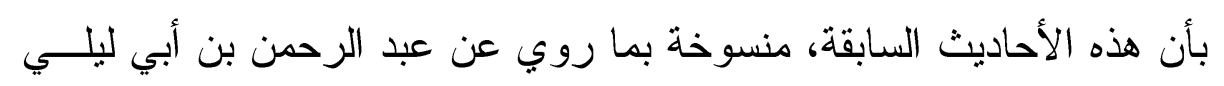

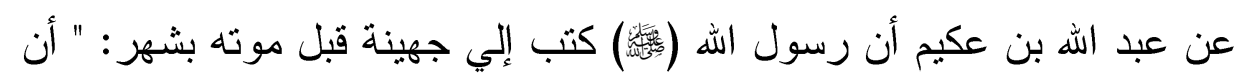

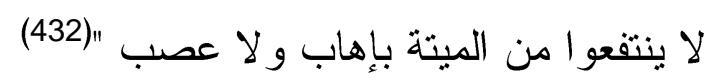

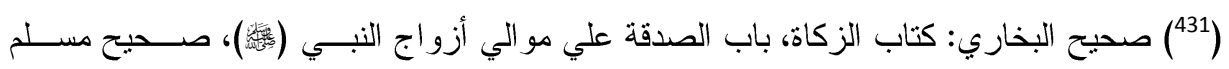

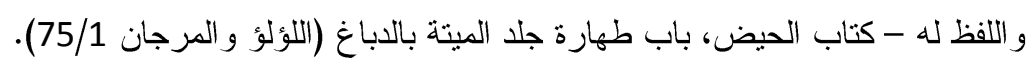

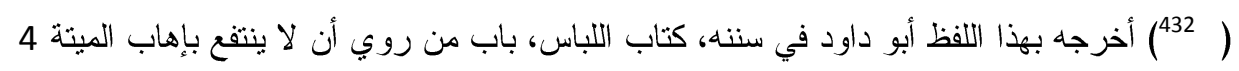

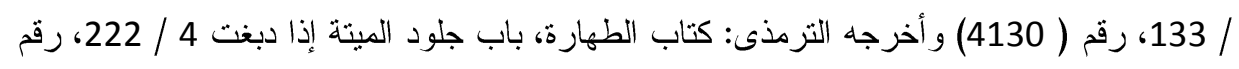

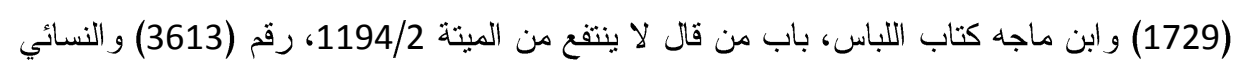

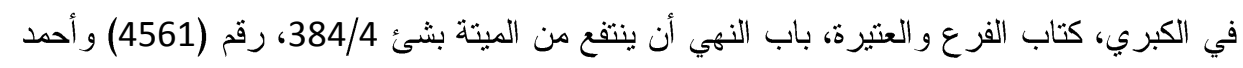

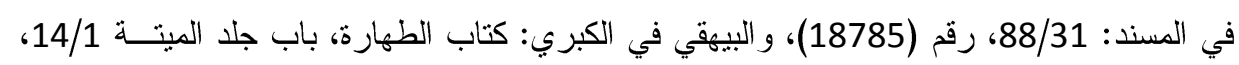

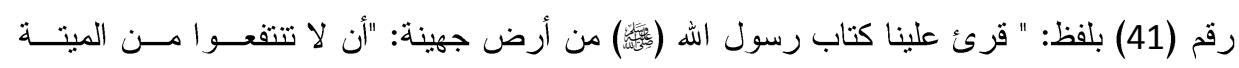

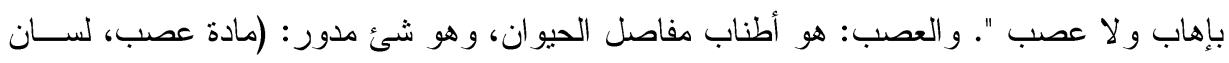

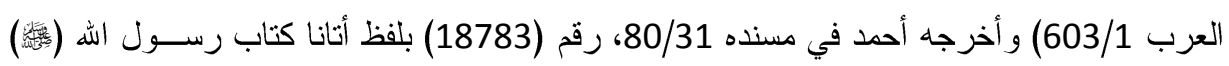

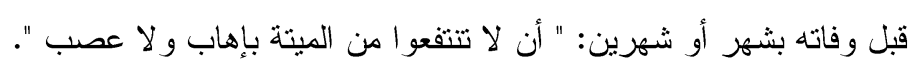


فهو ناسخ لما قبله من سائر الأحاديث الدالة علي طهارة جلود الميتة بالدباغ ؛

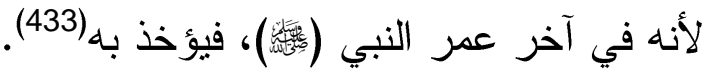

$$
\begin{aligned}
& \text { أجيب عنه من وجوه: }
\end{aligned}
$$

الوجه الأول: أن حديث عبد الله بن عكيم مرسل ؛ لأنه من كتاب لا يعـرف

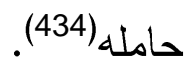

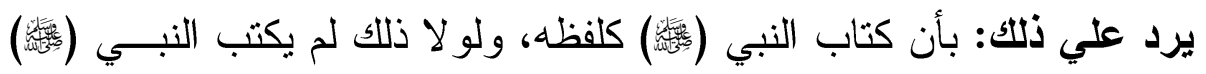

إلي أحد، وقد كتب إلى ملوك الأطر اف وغير هم، فلزمتهم الحجة، وحصل لــهـ

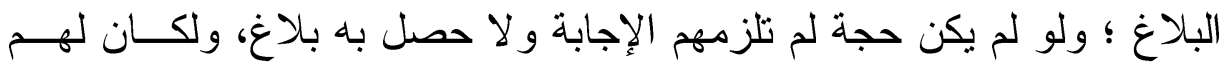
عذر في ترك الإجابة، لجهأهم بحامل الكتاب وعدالته (435).

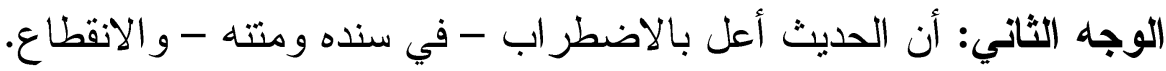

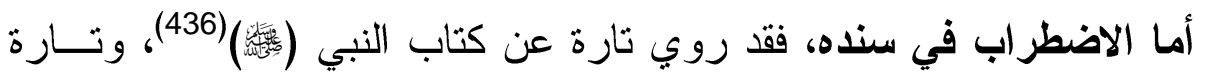
عن مشايخ من جعينة(437). أما الاضطر اب في متنه: فقد روي من غير تقييد في رواية الأكثر (438)،رووي

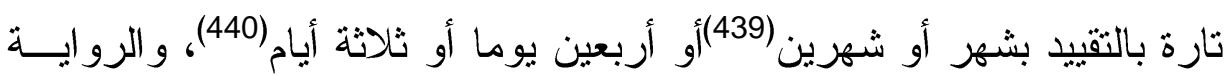

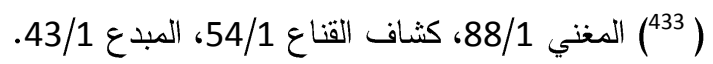
(434 المغني، المصدر السابق، نيل الأوطار 64/1 السفان

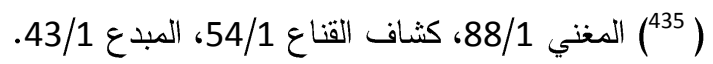

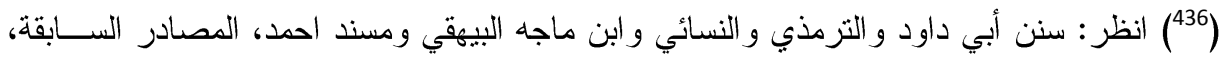

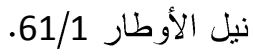

(337) سنن الترمذي، نيل الأوطار ، المصدرين السابقين.

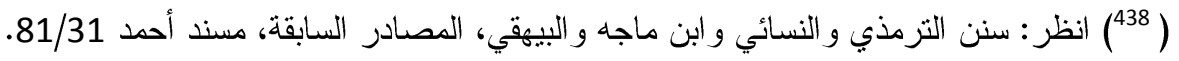

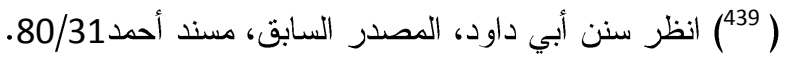

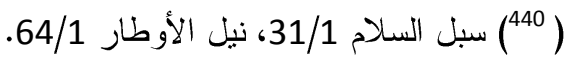


التي ذكرت التاريخ إنما رويت عن خالد الحذاء، وقد خالفه شعبة، وهو أحفــ منه، وشيخهما و احد (441).

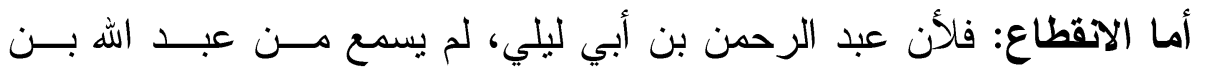

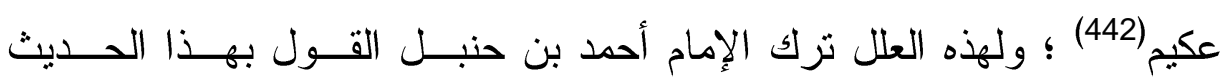
آخراً، وكان يذهب إليه أو لاً ويقول: إسناده جيد (443) الإمان. الوجه الثالث:

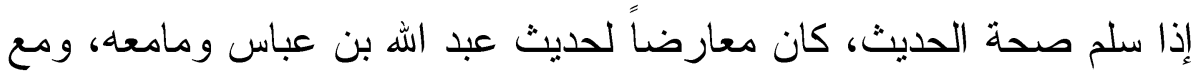

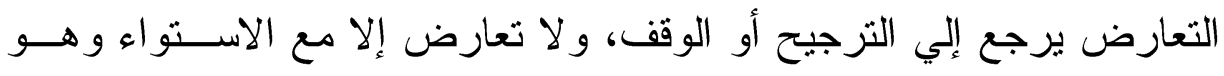

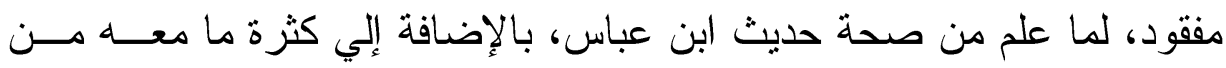
الرواة، و عدم ذلك في حديث ابن عكيم (444).

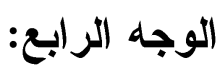

سلمنا جدلاً تأخر حديث عبد الله بن عكيم وصحته، بيد أنه مستععل علي مـــا

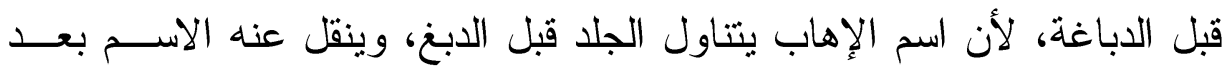

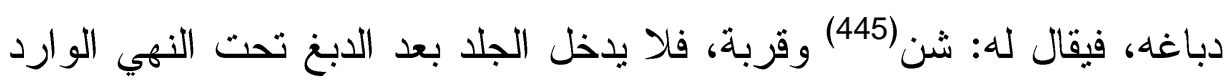
في هذا الحديث(446).

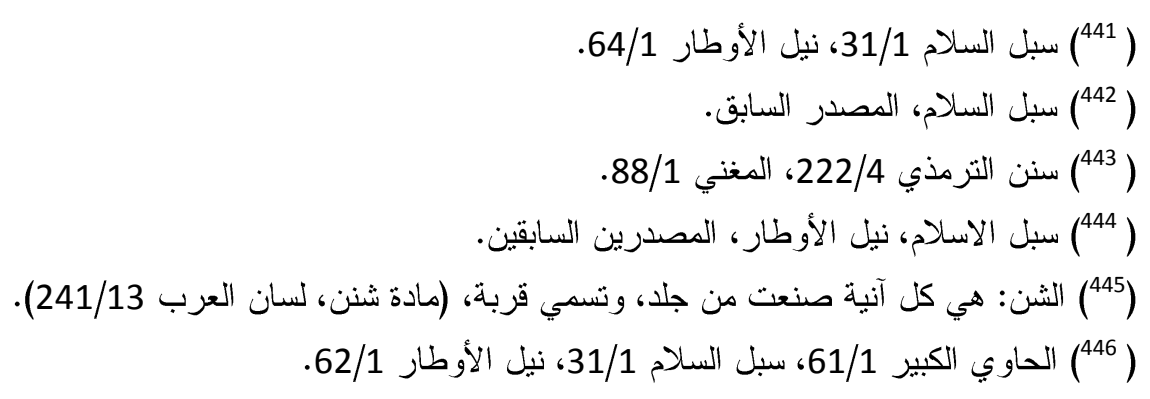




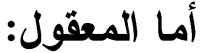

فاستدلو ا به فقالو ا: إن سبب نجاسة الجلد، هو الدماء و الرطوبات التي حلــت

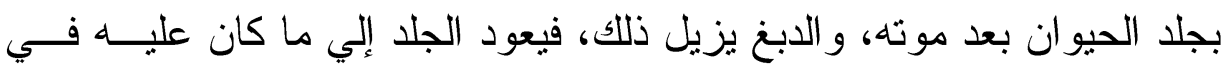
حال الحياة طاهر أ(447).

نوقش: بأن الجلد لو كان نجساً لأجل ما اتصل به من الرطوبة والـــدم، مـــا

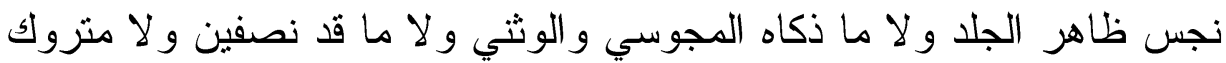

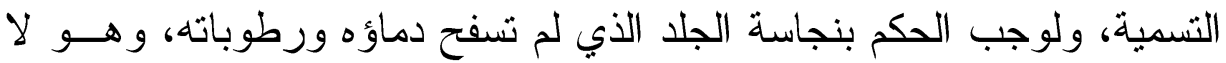
يجوز ، ومن ثم فالدليل لا يثبت مدعاكم(448).

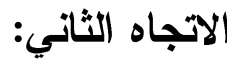

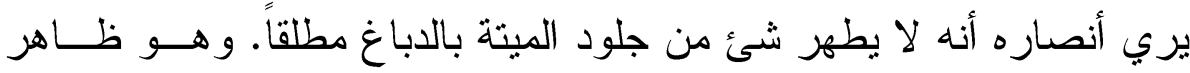

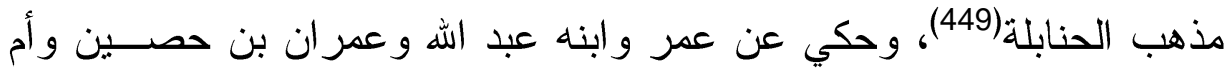
المؤمنين عائشة رضي اله عنهم(450). وقد استدل أصحاب هذا الاتجاه علي ما ذهبوا إليه بأدلة من الكتاب و الســنة

$$
\text { و أما الكتول. }
$$

فقوله تعالي: " حرمت عليكم الميتة "(451).

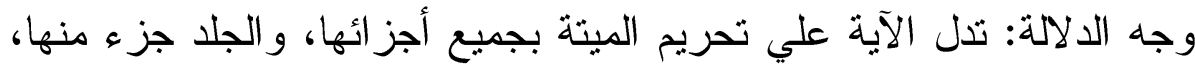

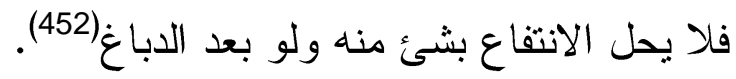

$$
\begin{aligned}
& \text { 88/1 المغني }
\end{aligned}
$$

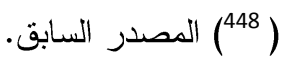

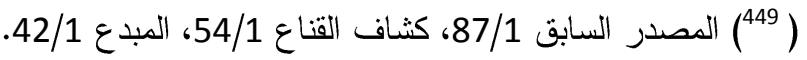

$$
\begin{aligned}
& \text { (87/1، 87/4 نيل الأوطار 61/1. } \\
& \text { (451) سورة المائدة، بعض الآية (35) نيل الاطنار (35). } \\
& \text { (53/1) الحاوي الكبير (53/1) }
\end{aligned}
$$


نوقش: بأن هذه الآية مخصوصة بالأحاديث الصحيحة السابقة الدالــة علــي طهارة الجلد بالدباغ(453). أما السنة:

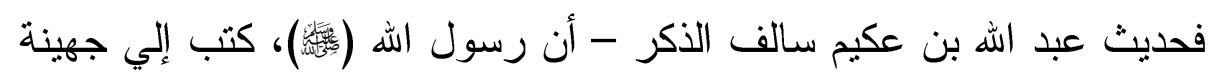

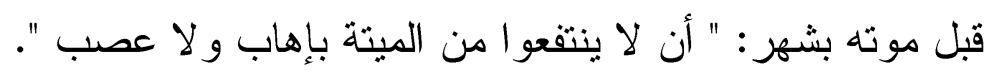

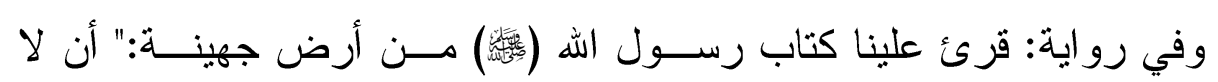

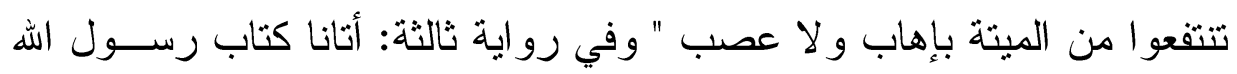

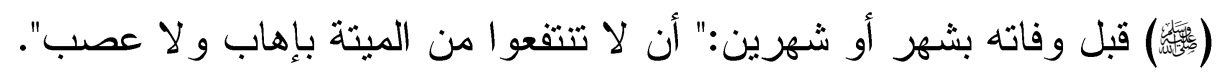

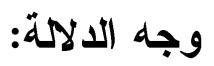

الحديث يدل دلالة واضحة، علي تحريم الانتفاع بشئ من جلود الميتة مطلقاً،

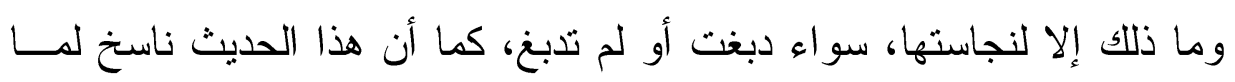

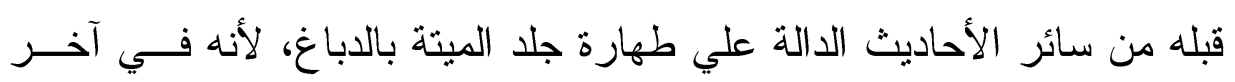
عمر النبي(

\section{يناقش هذا الاستدلال:}

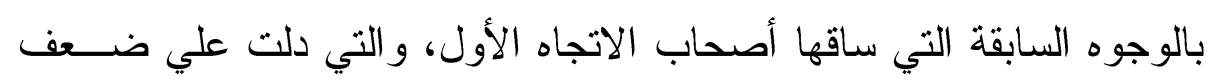

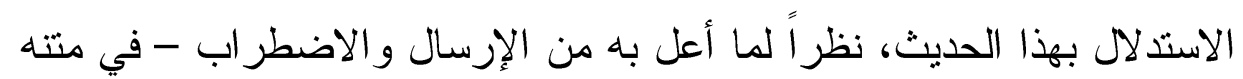

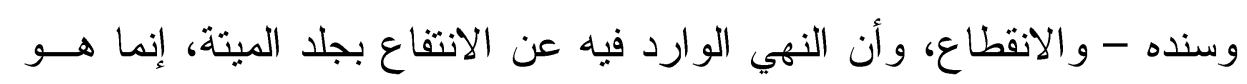
بالنسبة لما قبل الدباغ(455) و والانطاع، وان

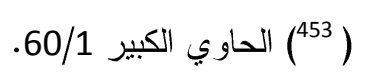

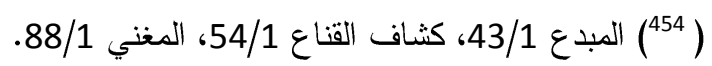
(455) ير اجع ص 334 ، 335 من هذا البحث. 


\section{أما المعقول:}

\section{فاستلالوا به من وجهين:}

الوجه الأول: أن الجلد جزء من الميتة كاللحم، فكما أن اللحم لا يطهر بشــئ،

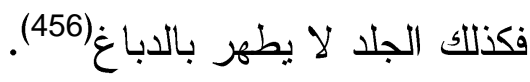

نوقش: بأن قياس الدبغ علي اللحم باطل ؛ لأنه في مقابلة نصوص، فلا يلتقت

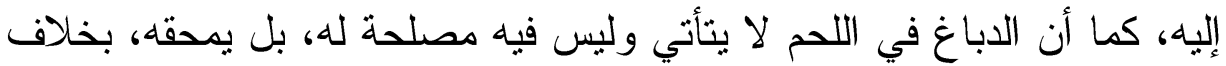
الجلد فإنه ينظفه ويطيبه ويصلبه(457). الوجه الثاني:أن العلة في نجاسة الجلد هي الموت، وهو ملهـ ملازم له، لا بــزول

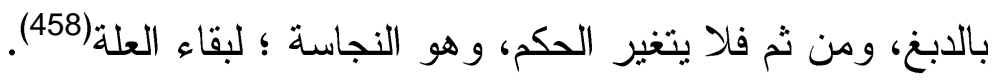

\section{نوقش:}

بأن قياس الدباغ علي الموت، قياس مع الفارق ؛ لأنه في مقابلة نصوص،فهو باطل (459).

الاتجاه الثالث: يري أنصاره أن جلود الميتة التي تستحيل طاهرة بالدباغ، هي

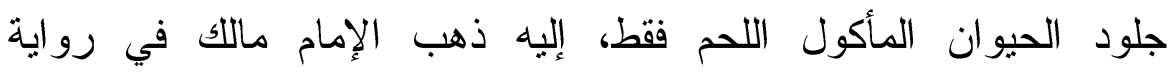

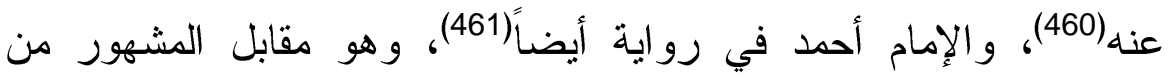
مذهب الحنابلة(462)، وقد حكي عن عمر وابن مسعود وعطاء والحسن

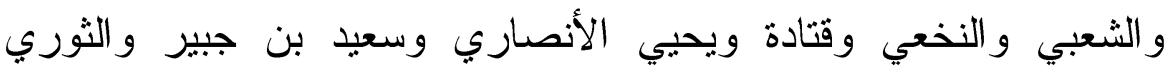

$$
\begin{aligned}
& \text { (456) المجموع 217/1، المغني 88/1. }
\end{aligned}
$$

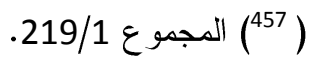

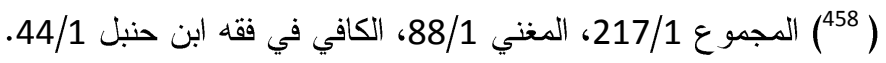

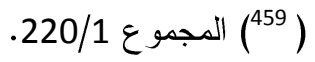

$$
\begin{aligned}
& \text { (2979/1 (460) البيان و التحصيل 220/1. الاستخكار }
\end{aligned}
$$

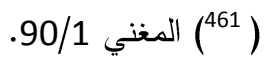

$$
\begin{aligned}
& \text { (462 المصدر السابق 87/1، المبدع 44/1، الكافي 44/1. }
\end{aligned}
$$


و الأوزاعي وأبو ثور و اللبث وأبي ثور وابن المبارك وإسحاق بن راهوية، رضي الله عنهم(463).

وقد استدل أصحاب هذا الاتجاه علي ما ذهبو ا إليه بأدلة من السنة و المعقول. أما السنة:

\section{فأحاديث كثيرة منها:}

[أ] روي عن جون بن قتادة عن سلمة بن المحبق أنه قال، قــال رســول الله

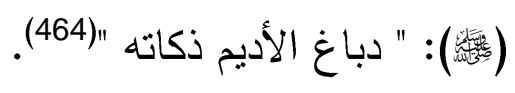

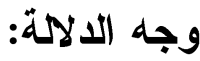

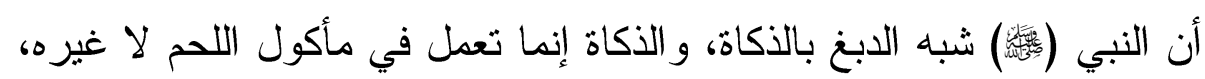

فكذلك الدباغ (465).

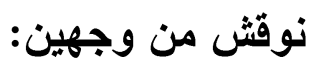

الوجه الأول: أن الحديث الذي استدلو ا به ضعيف لونه لا تقوم به حجة، لأن فــي

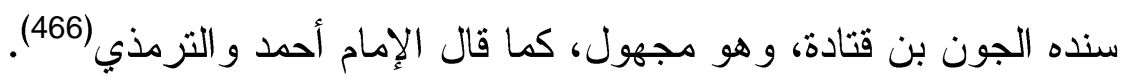

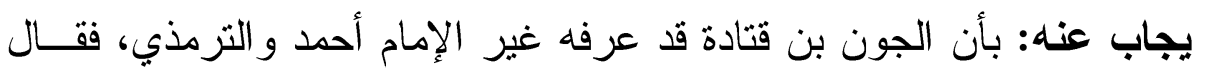

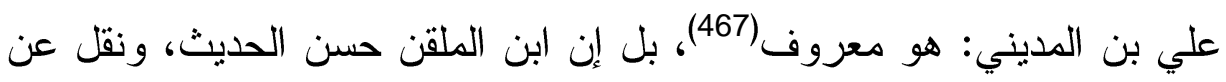
البيهقي و الدارقطي بأن إسناده حسن، ورجاله كلهم ثقات (468).

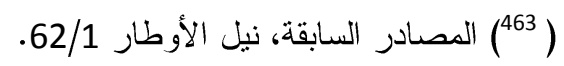

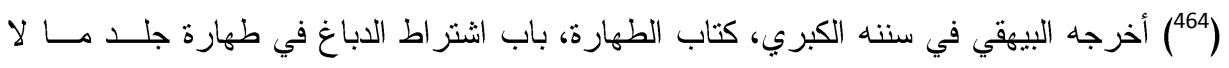

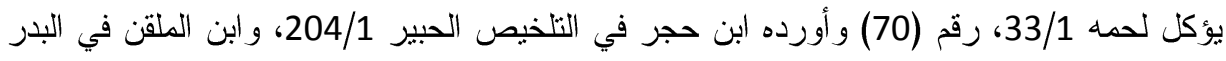
المنير 607/1، وقال: " حديث حسن، وقال البيهقي: رواته كلهم تقات، وقـــال الــارقطني: إبـــاده

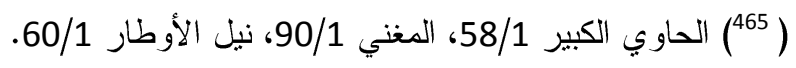

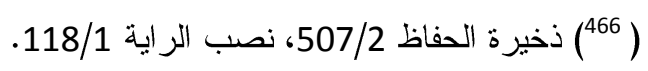


الوجه الثاني: أن المر اد بالحديث، أن دباغ الأديم مطهر له ومبيح للانتفاع به كالذكاة، فإنها تطهر اللحم و الجلد أيضاً (469).

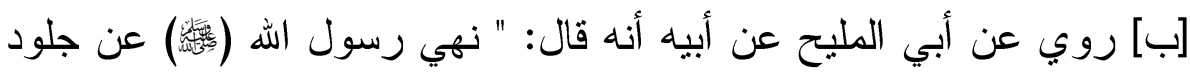
السباع أن تفرش "(470).

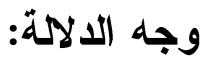

أن السباع - - وهي غير مأكولة اللحم - لو كانت تطهر بالدباغ، ما نهـي

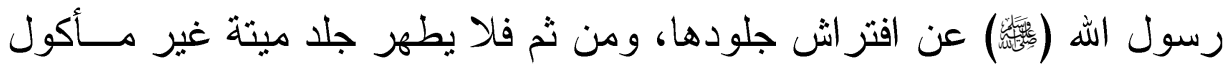
اللحم بالدباغ (471).

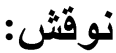

بأن النهي عن افتر اش جلود السباع محمول علي ما قبل الدباغة ؛ لأنها كانت

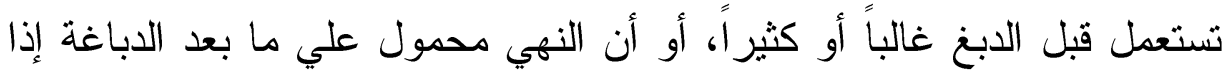

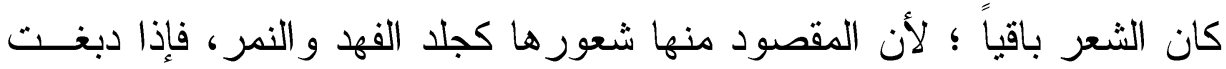

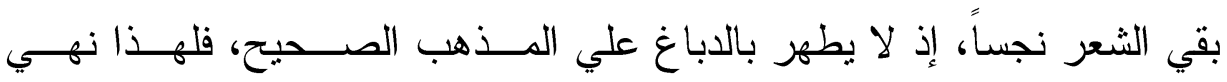
عنها (472) بقي

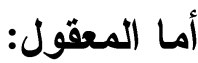

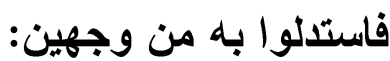

(467 (المجموع 218/1، نبل الأوطار، المصدر السابق.

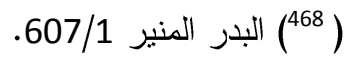

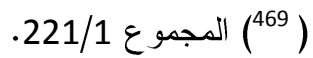
(470 أخرجه: أبو داود، كتاب اللباس، باب جلود النمور و السباع 116/4، رقم (4134) و والتزمذي،

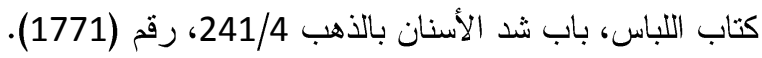

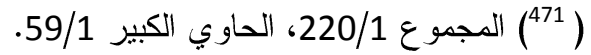

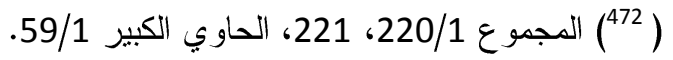


الوجه الأول: أن غير مأكول اللحم لا يطهر جلده بالذكاة، فوجب أن لا يطهر بالدباغة أيضاً كالكلب و الخنزير (473).

نوقش: بأن قياس غير مأكول اللحم علي الكلب و الخنزير، قياس مع الفارق ؛

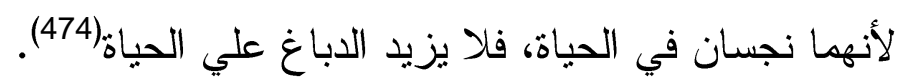

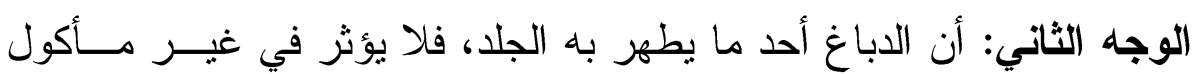
اللحم كالذكاة(475).

نوقش: بأن قياس الدبغ علي الذكاة، قياس باطل، لأن الذكاة لا مدخل لها في إز الة الأنجاس، وللاباغة مدخل في إز الة الأنجاس (476).

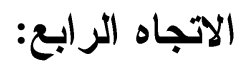

يري أنصاره أن جميع جلود الميتة تستحيل طاهرة بالدباغ عدا جلد الخنزيــر

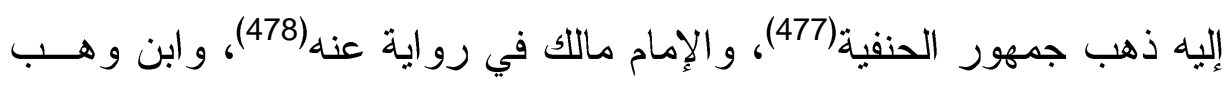
و ابن نافع من المالكية(479).

وقد استذل أصحاب هذا الاتجاه علي ما ذهبوا إليه بحديث عبد اله ابن عباس

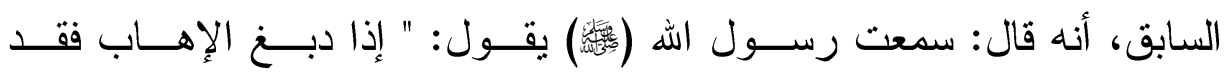

$$
\begin{aligned}
& \text { (221/1 المصدر السابق، المجموع (773) الهدرئ. } \\
& \text { (474) (المصدرين السابقين. } \\
& \text { (775) الحاوي، المصدر السابق، المغني 90/1 (474) }
\end{aligned}
$$

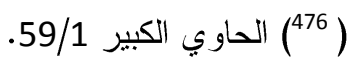

(477) المبسوط 370/1 - 372، حاشية ابن عابدين 203/1، 204، بدائع الصنائع 85/1

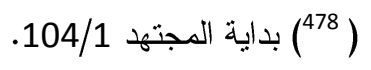

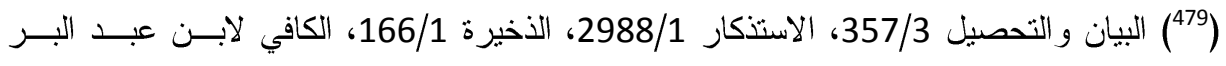


طهر "(480) وقالو أبأن هذا الحديث نص في طهارة جلود الميتة بالدباغ، وأنه

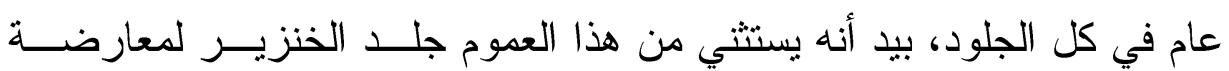

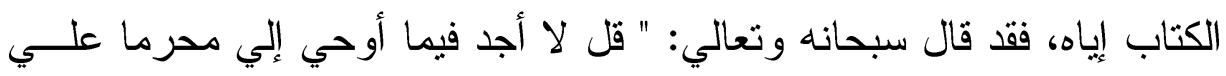

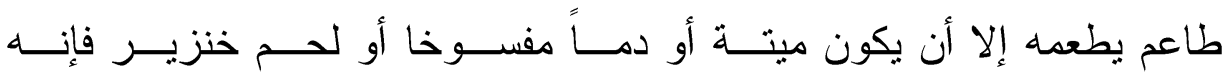

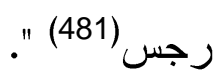

\section{وجه الالاية:}

أن الضمير في قوله تعالي: " فإنه رجس " يعود إلي المضـــاف إليــه وهــــ

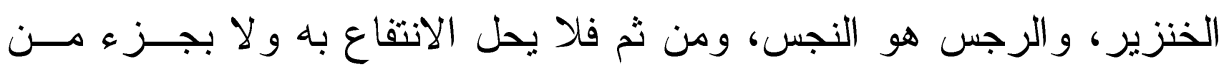

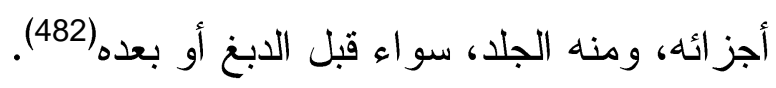
نوقش هذا الاستدلال من وجهين:

الوجه الأول: أنه يحتمل أن الضمير في قوله تعالي: " فإنه رجس " يعود إلي

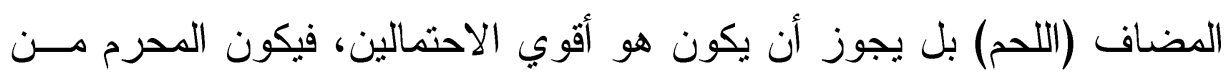

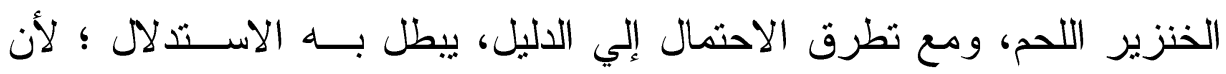

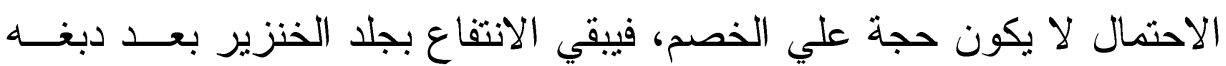
علي الإباحة(483). الوجه الثاني: أن رجسية الخنزير علي تسليم شمولها لجميعه، ربمــا تكــون مخصصة بأحاديث الدباغ (484).

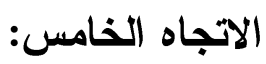


يري انصاره أن جميع جلود الميتة تستحيل طاهرة بالدباغ، عدا جلد الكلـ

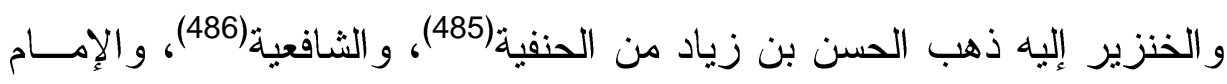

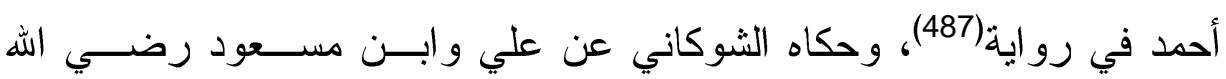
عنهما (488) وقد روي عن محمد بن الحسن أن جلد الفيل لا بطهر بالدباغ(489) وقد استل أصحاب هذا الاتجاه علي ما ذهبوا إلبه بالسنة و المعقول. أما السنة: فعموم حديث عبد الله بن عباس السابق(490)، و الدال علي طهارة جلد الميتــة

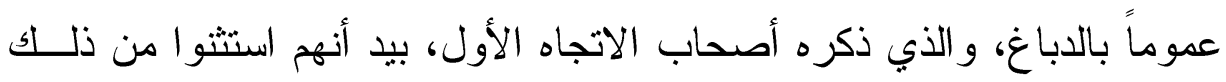
جلد الخنزير ، بما قاله أصحاب الاتجاه الرابع، وقد سبق مناقشة أدلتهم.

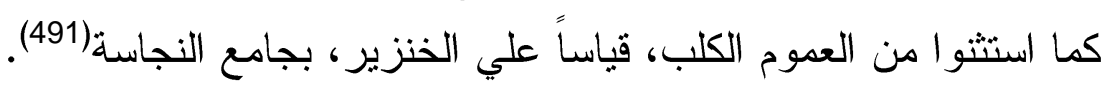

\section{وقد نوقش هذا الاستثناء:}

$$
\begin{aligned}
& \text { (885) بدائع الصنائع 85/1، شرح فتح القدير 83/1. }
\end{aligned}
$$

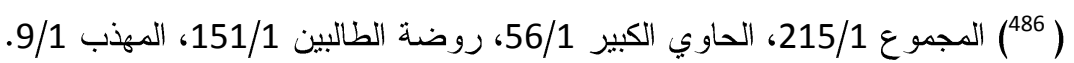

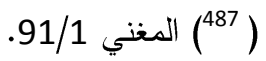

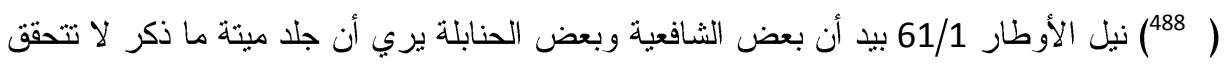

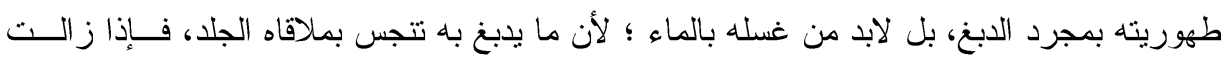

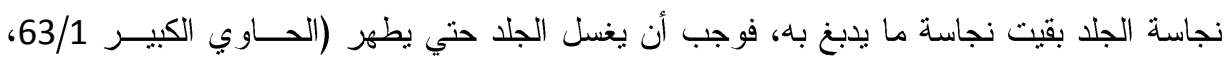

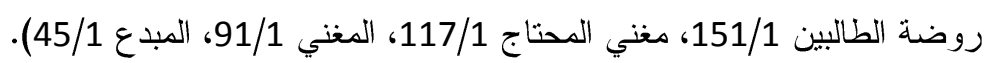

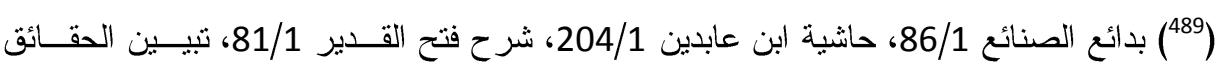


بأن قياس الكلب علي الخنزير، قياس باطل، لأن الانتفاع بالكلب مبـــاح فــي

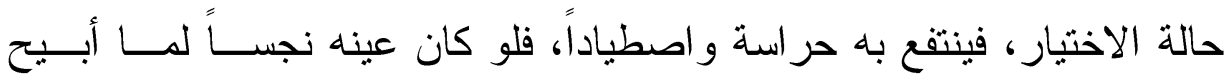
الانتفاع به، أما الخنزير فلا ينتفع به بحال، فلا يصح القياس عليه (492).

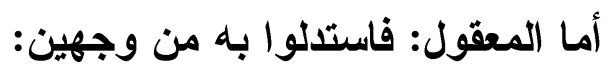

الوجه الأول: أن الحياة أقوي في التطهير من الدباغ، لتطهير ها جميع الحيوان

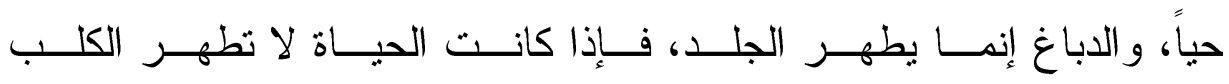
و الخنزير ،فالدباغ أولي (493، ولان.

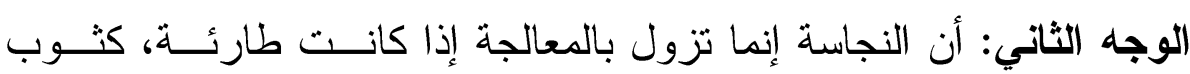

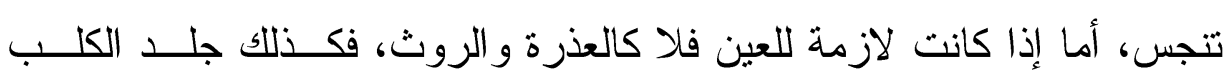

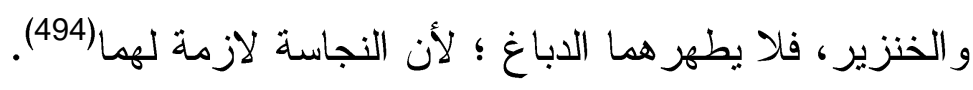

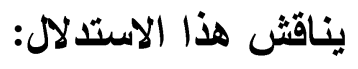

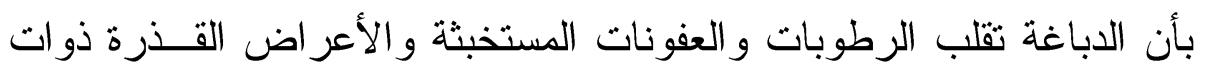

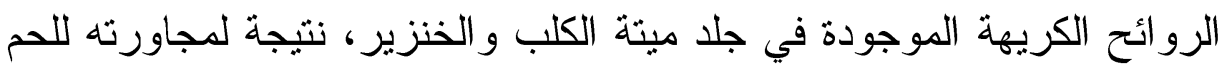

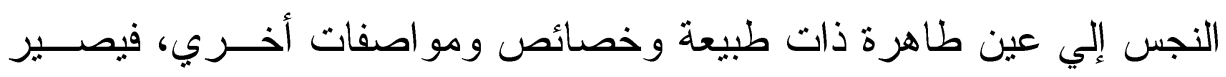
الجلد بمثابة الخمر إذا تخللت، طاهر اً ينتفع به. أما محمد بن الحسن: فقد استدل علي ما ذهب إليه من أن جلد الفيل لا بطهر بهر

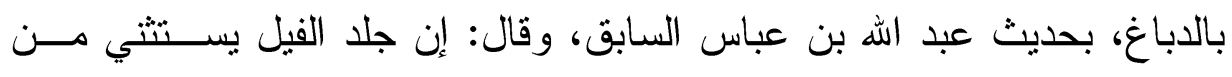
عموم الحديث ؛ لأنه نجس العين كالخنزير، فلا يطهر جلده بالدباغ(495).

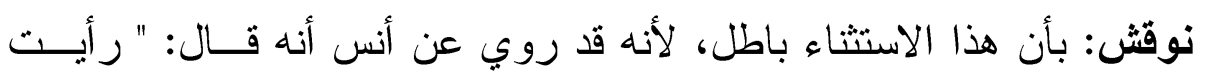

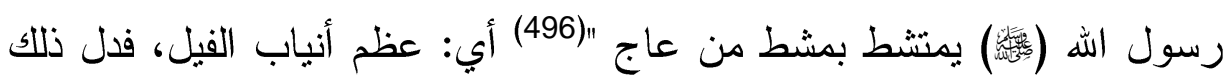

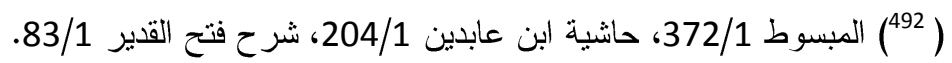
57/1 الكباو

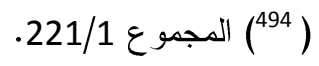
(495 المبسوط 372/1، حاشية ابن عابدين 204/1، بدائع الصنائع 86/1، شرح فتح القير 81/1. doi: $10.12816 / 0004230$ 


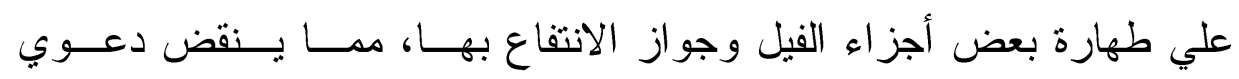
الاستثناء (497).

يجاب عنه: بأن هذا الحديث ضعيف، فقد قال البيهقي عنه: " قال عثمان: هذا منكر. قال الشيخ: في سنده بقية بن الوليد، وروايته عن شــيوخه المجهــولين ضعيفة "(498)، ومن ثم فلا تقوم بـ فيه حجة. الاتجاه السادس: يري أنصاره أن جميع جلود الميتة تستحيل طاهرة بالدباغ، لكن يطهر منها الظاهر فقط. إليه ذهب المشهور من مذهب المالكية(499). وقد استدل أصحاب هذا الاتجاه علي ما ذهبو الإليه بالسنة و المعقول.

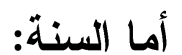

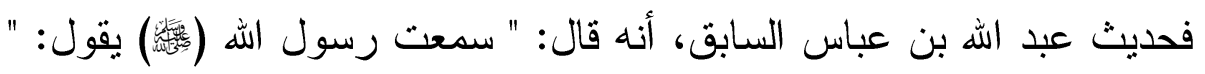
إذا دبغ الاهاب فقط طهر "(500). وجه الدلاة: الحديث يدل علي طهارة الجلد بالدباغ، بيد أن المراد بالطهارة،

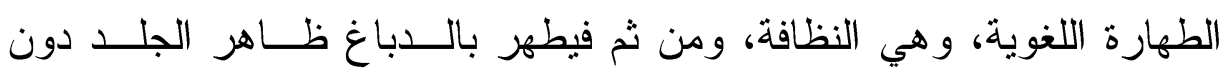
باطنه (501).

(296) أخرجه البيهقي في سننه الكبري، كتاب الطهارة، باب المنع من الإدهان في عظم الفيلة 26/1،

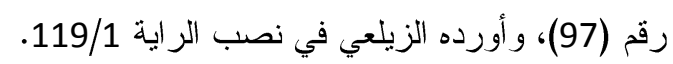

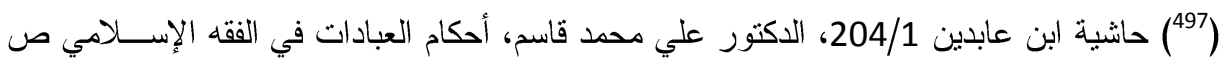

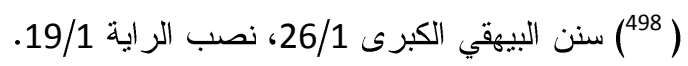

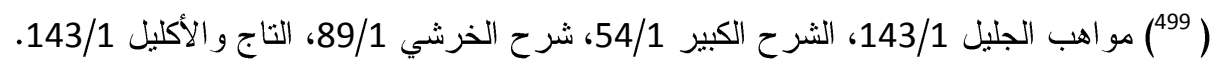

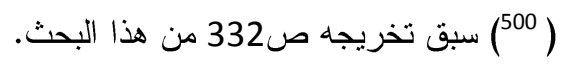
343 (501) الثرح الكبير للدردير 54/1، مو اهب الجليل 143/1، شرح الخرشي 89/1. 
يناقش: بأنه لا يسلم بأن المر اد الطهــارة اللغويــة، بــلـ الــــر اد الطهــارة

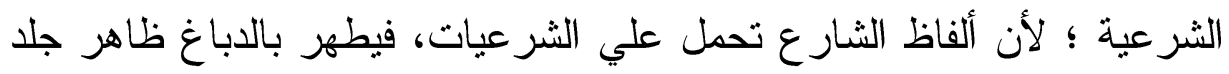

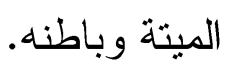
أما المعقول: - المائه وباطنه فاستدلو ابه فقالو ا: إن الدباغة لا تؤثر إلا فيما لاقته، وهوظاهر الجلد، فوجب أن يطهر بها فقط دون باطنه(502). نوقش: بأنه لا يسلم بأن الدباغة تؤثر فيما لاقته فقط، وهو ظاهر الجلد، بل تؤثر في

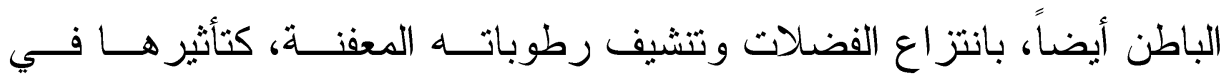
الظاهر (503). (الناطن.

\section{الاتجاه المختار:}

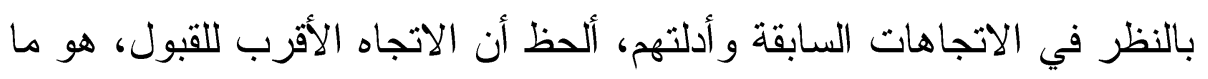

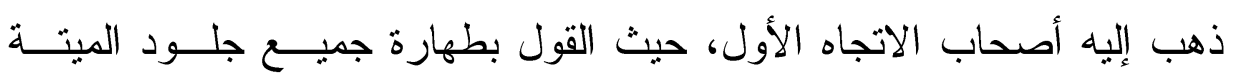

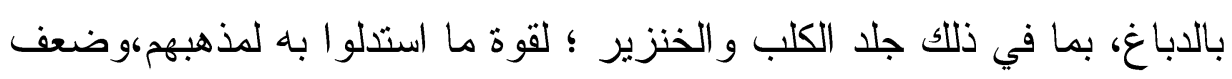

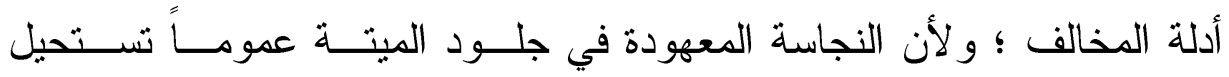

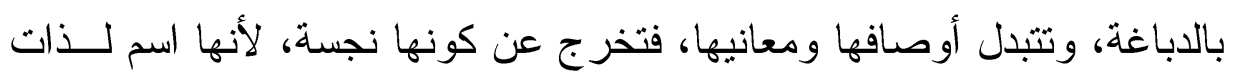

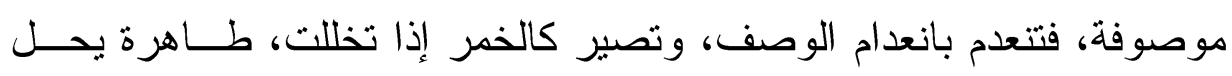
الانتفاع بها. ولهذا فإن هذا الاتجاه هو الأولي بالقبول والأحق بالتأييد و الترجيح.

$$
\begin{aligned}
& \text { (221/1 202 المجم، الحاوي الكبير 61/1. }
\end{aligned}
$$

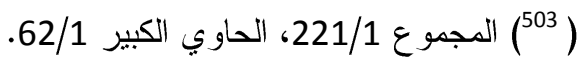




\section{الغصن الثاني}

الآثار المترتبة علي استحالة جلا الميتة بالاباغ في الفقه الإسلامي

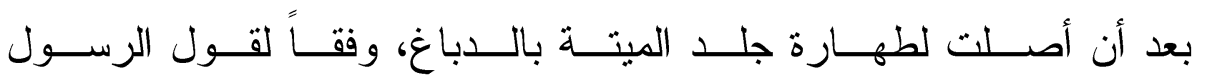
(")

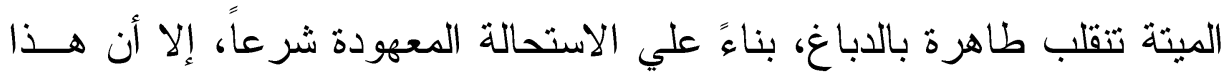

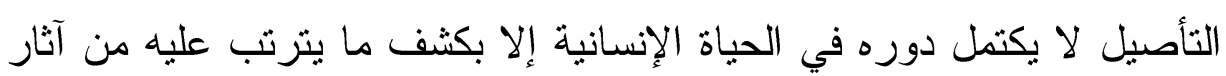

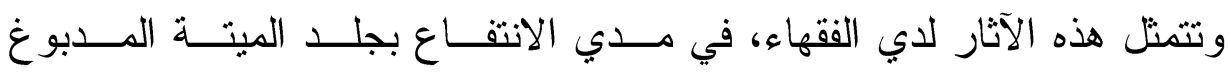

ومساحته،وقد كان هذا محل خلاف بينهم، أسفر عنه ظهور خمسة اتجاهات:

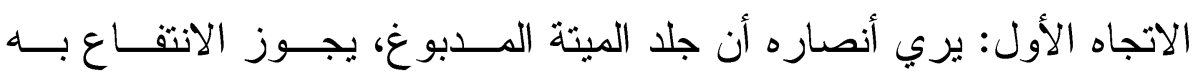

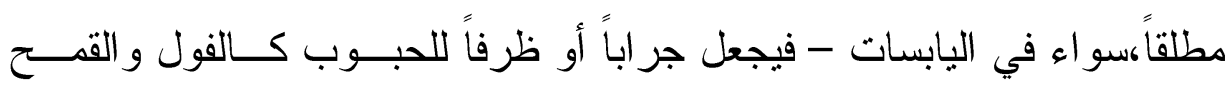
و الثعير والأرز ونحوهم - أو في المائعات - فيوعي به الماء و الزيت و اللبن

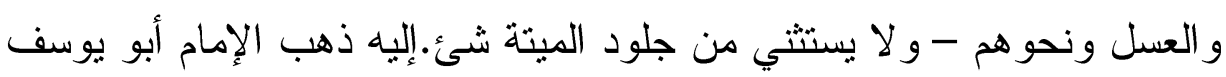

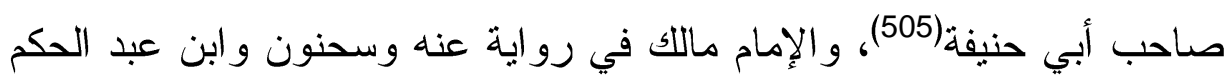

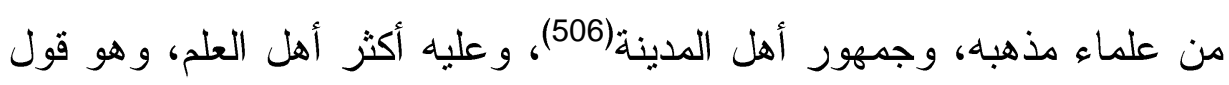

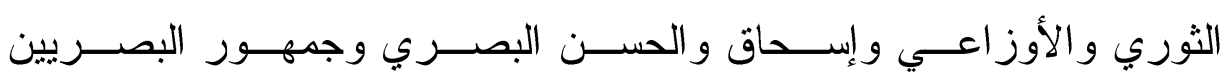
و الكوفيين (507).

وقد استدل أصحاب هذا الاتجاه علي ما ذهبوا إلبه بأدلة من السنة و المعقول.

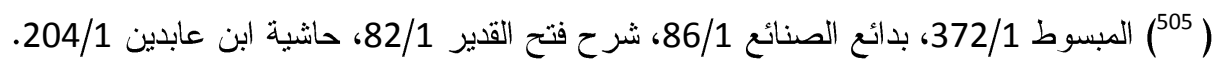

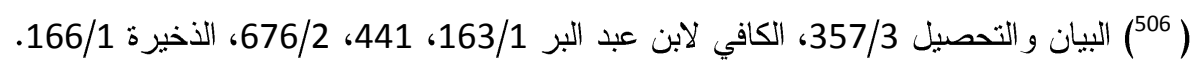
2988/1 (الاستخكار (507) 


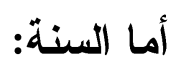

[أ] ما أخرجه الإمام مسلم عن ابن عباس رضي الله عنهما أنه قال: " سمعت

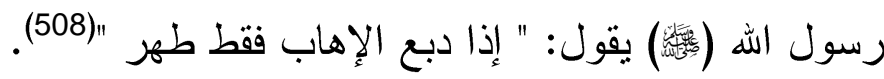

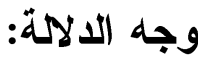

الحديث يدل علي طهارة الجلود بالدباغ، وهو عام في جميع الجلــود، وأنـــه

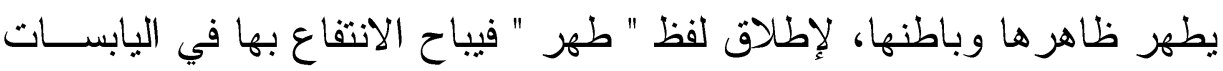
و المائعات(509).

[ب] ما أخرجه الإمام البخاري عن ابن عبــاس عــن أم المــؤمنين ســودة

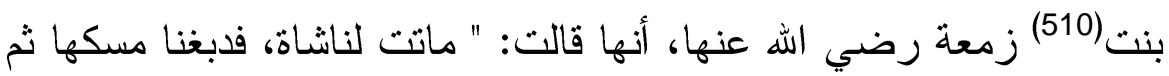

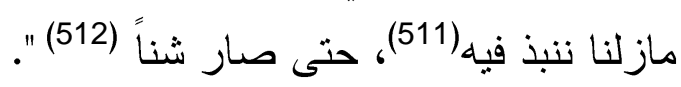

وجه الدلالة:

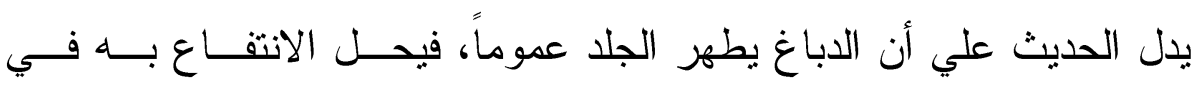

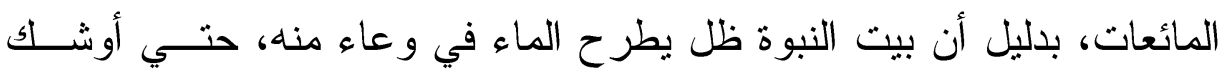

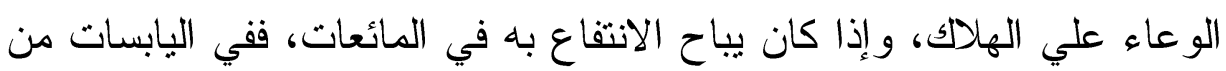

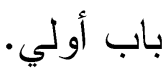

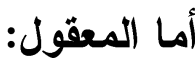

فاستدلو ابه فقالو ا: إن ما بطهز به ظاهر الجلد بطهر به باطنه، كالذكاة، فإنها تطهر ظاهره وباطنه(513).

(508) سبق تخريجه ص 332 من هذا البحث.

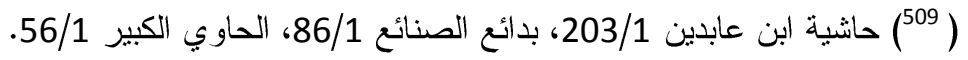

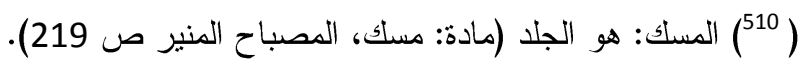

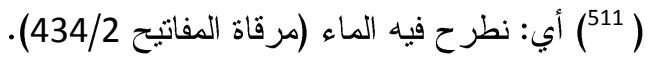

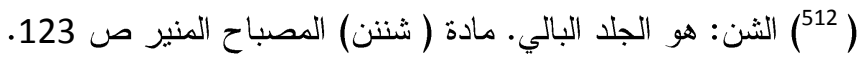
(52/1 (5213. الحاوي الكبير. 


\section{الاتجاه الثاني:}

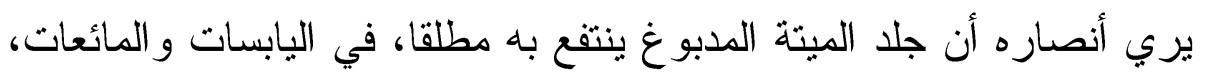

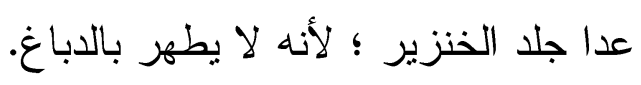

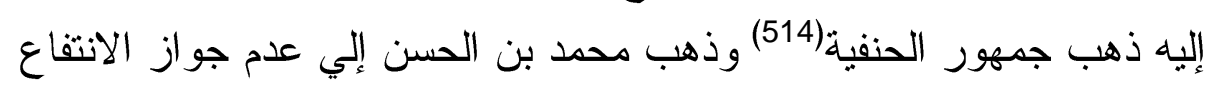
بجلد الفيل ؛ لأن جلده لا يطهر بالدباغ (515).

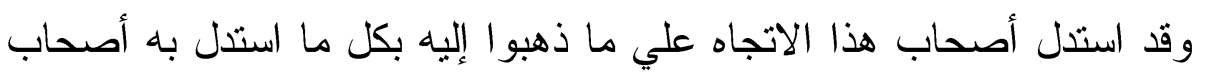

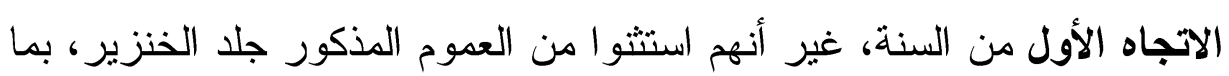

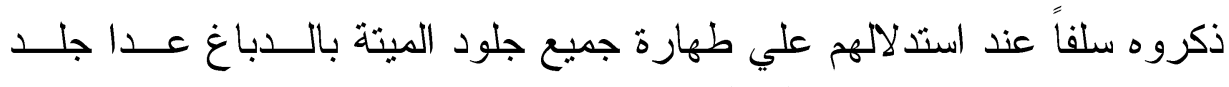
الخنزير ، وقد سبق مناقشتهم (516).

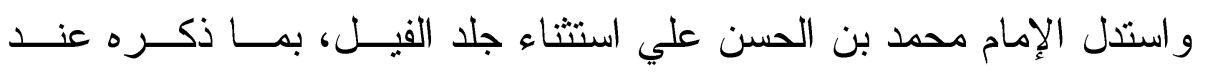

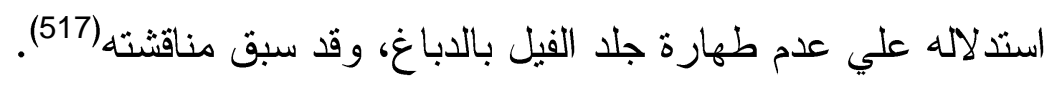

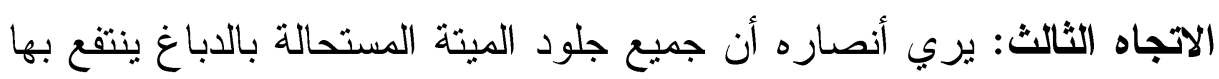

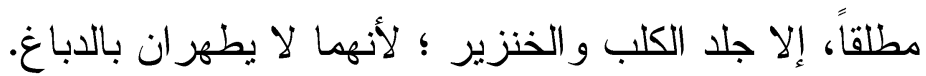

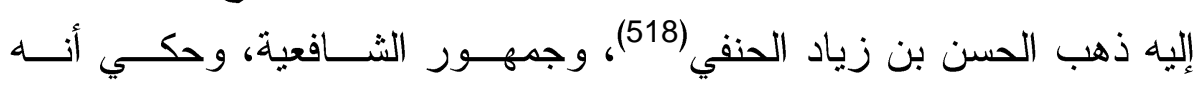
الصحيح عندهم (519). وقد استدلو ا علي ما ذهبو ا إليه بعموم الأحاديث السابقة في أدلـــة أصـــاب الـاب

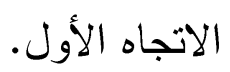

(514) المبسوط 370/1، حاشية ابن عابدين 203/1، بدائع الصنائع 86/1.

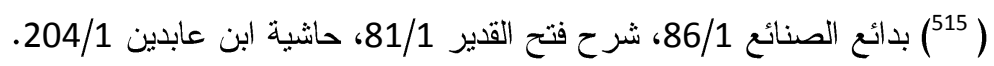

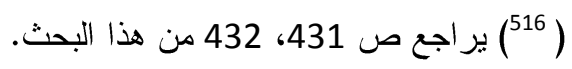

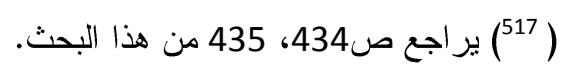

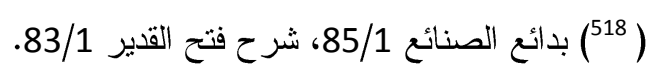




\section{أما دليلهم علي الاستثناء فبما يأتي:}

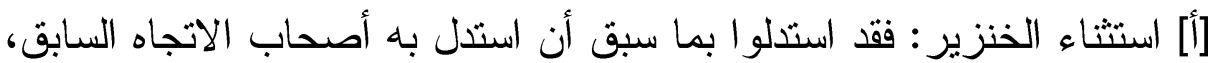
وقد سبق مناقشتهم (520).

[ب] استثناء الكلب: فقد استدلو ا بما سبق أن استدلو ا به علي طهارة جميع جلود الميتة بالدباغ عدا الخنزير و الكلب، وقد سبق مناقشهم (521).

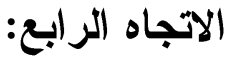

يري أنصاره عدم جواز الانتفاع بجلد الميتة المدبوغ إلإن في اليابسات فقـط.

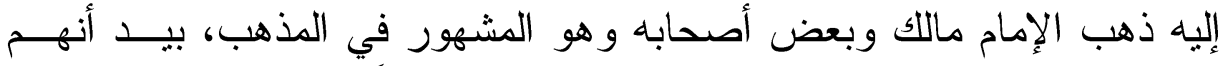
استثنوا من ذلك جلد الخنزير ، فلا ينتفع به عندهم مطلقاً علي المشهور (522).

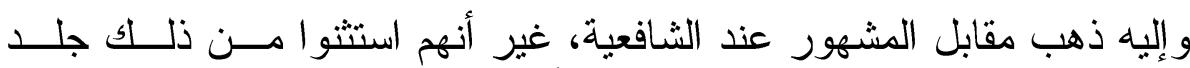
الكلب و الخنزير ، فلا ينتفع به عندهم مطلقابل (523.

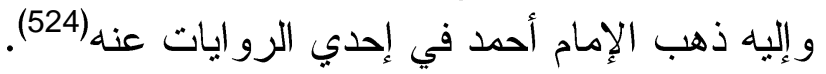

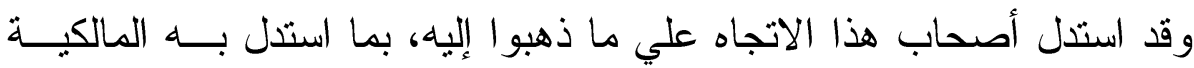

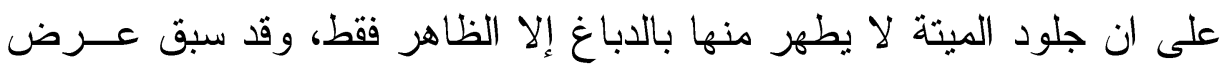

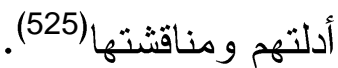
كما استدلو ا علي ذلك أيضاً بأدلة أخري من آثار الصحابة والمعقول:

$$
\text { (521) }
$$

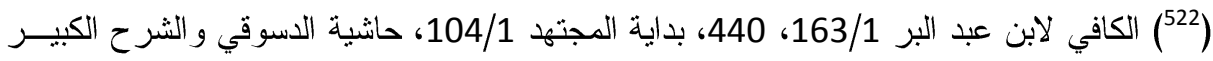

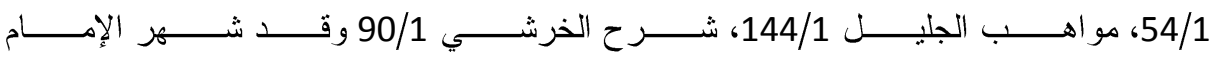

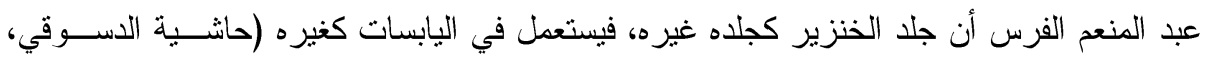

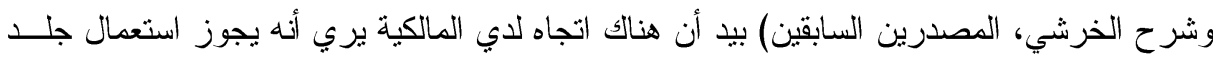

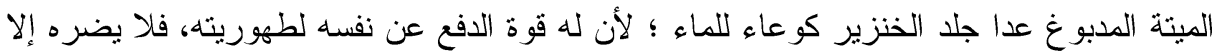

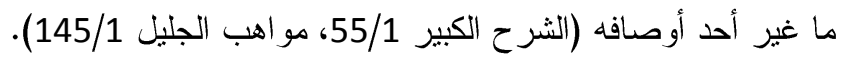

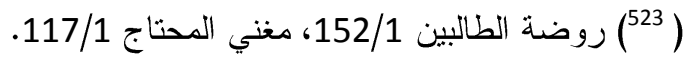

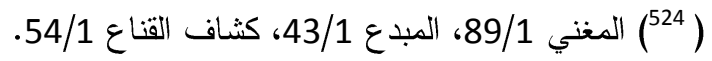
(525) ير اجع ص345، 346 من من هذا البحث. 


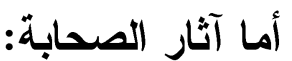

فإن الصحابة لما فتحو ا بلاد فارس، انتقعو ا بسروج دو ابهم وأسلحتهم، مع أن

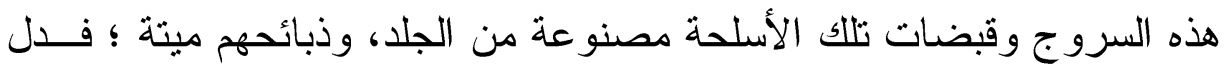

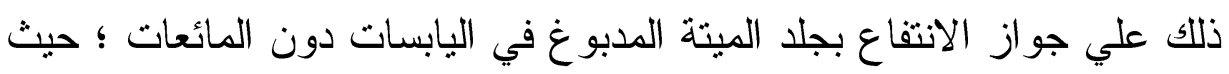
إن وجوه الاتنفاع هنا من قبيل اليابس لا المائع(526).

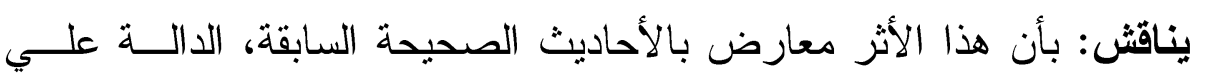
جو از الانتفاع بجلد الميتة المدبوغ مطلقاً في اليابسات و المائعات.

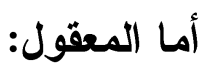

فاستدلو ابه فقالو ا: إن آلة الدبخ لا تصل إلي باطن الجلد، في المائعـات؛ لأن استعماله فيه يفضي إلي تعدي النجاسة(527).

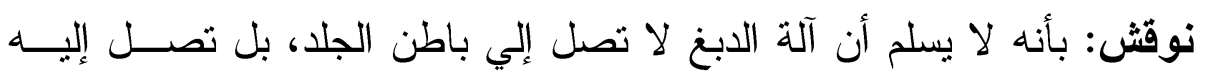
بو اسطة الماء ورطوبة الجلد (528). وقد استدل المشهور من مذهب المالكية علي استثناء جلد الخنزير بالقول بأن

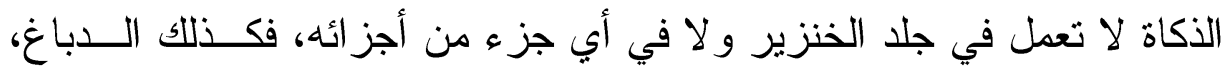
ومن ثم فلا يجوز الانتفاع به مطلقاً (529). يناقش هذا: بأن قياس الدباغ علي الذكاة قياس باطل، لأن الذكاة لا مدخل لها لها في إز الة الأنجاس، وللاباعة مدخل في إز الة الأنجاس (530).

$$
\begin{aligned}
& \text { (227) المغنى، المبدع، كثاف القناع، المصادر السابقة. }
\end{aligned}
$$

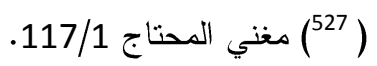

$$
\begin{aligned}
& \text { (528) (لمصدر السابق. } \\
& \text { (529) الثرح الكبير 54/1، شرح الخرشي 90/1. }
\end{aligned}
$$

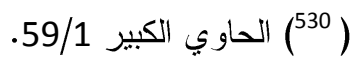




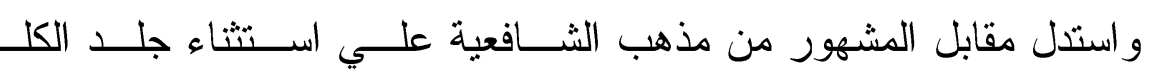

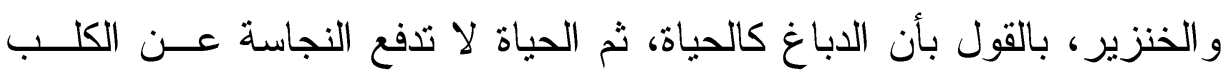

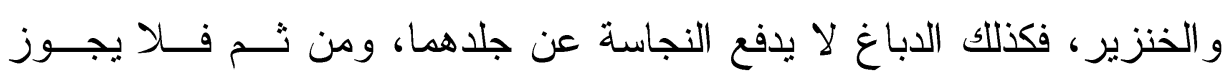
استعمالهما مطلقاً (531). يناقش هذا: بأن الدباغ يحيل الرطوبة و النتن و الفساد الموجود في جلد الكلب

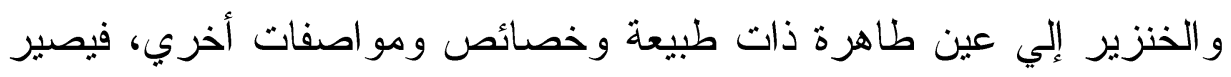
الجلد بمثابة الخمر إذا تخللت، طاهر اً ينتفع به. الاتجاه الخامس:

يري أنصاره أنه لا يجوز الانتفاع بجلد الميتة المدبوغ مطلقاً ؛ لأنه لا يطهر

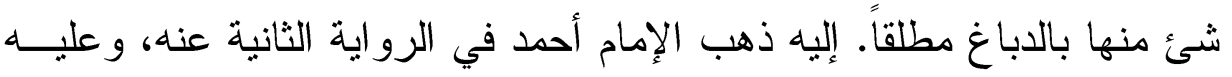
أكثر أصحابه و هو ظاهر المذهب(532.

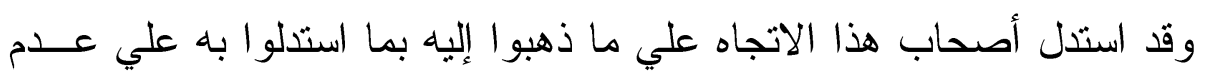

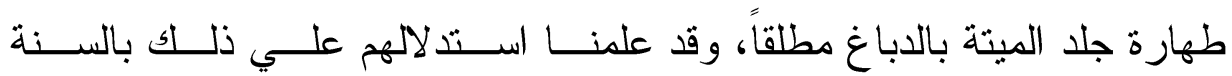
و المعقول، وسبق مناقشتهم (533).

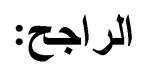

بالنظر في الاتجاهات السابقة وأدلتهم، ألحظ أن الاتجاه الأقرب للقبــول، التحاه هو ما ذهب إليه أصحاب الاتجاه الأول؛ حيث القول بجواز الانتفاع بجلد التهات الميتة

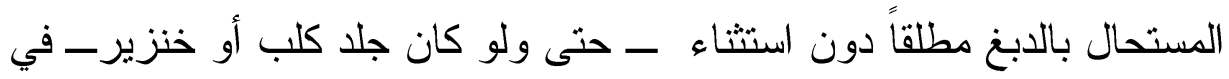

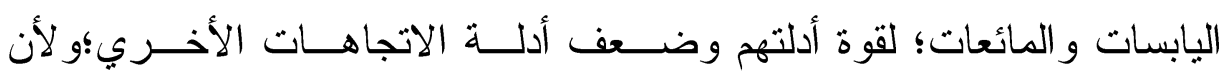

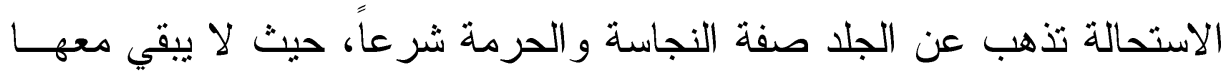

(531 المهذب 9/1، المجموع 214/1، 215، الحثاوي الكبير 56/1، 56/1، 57.

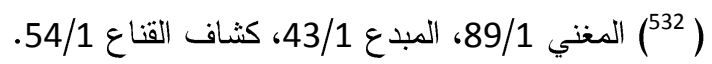
(533) ير اجع ص336 (332) ـ 338 من هذا البحث. 
من خصائص وصفات العين المحرمة أو النجسة شئ يمكن أن يوصف بالحرمة

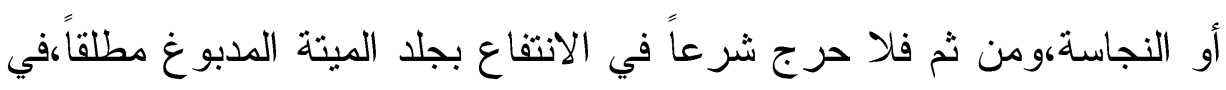
اليابسات و المائعات، وكذا استعمال الأشياء المصنو عة فئه منه كالملابس و الحقائب الأحذية و المفروشات و عجل السيارات ونحو ذلك.

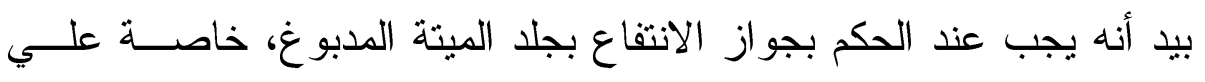

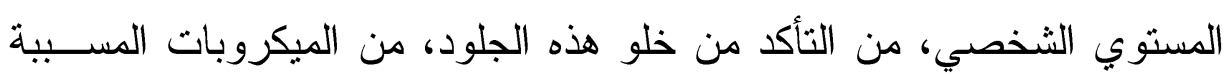

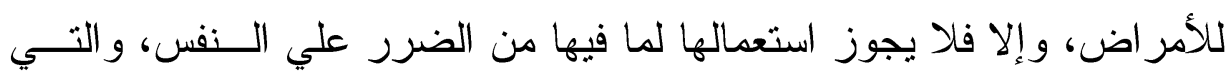

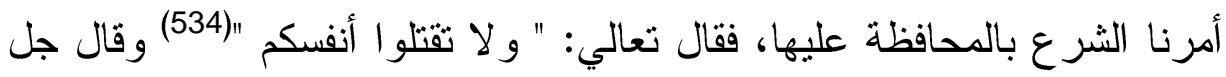

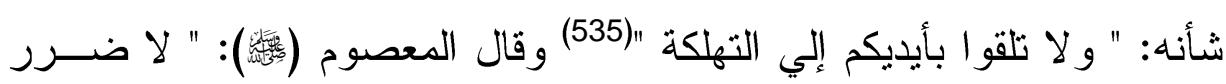

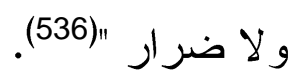

\section{المطلب الثالث}

موقف الفقه الإسلامي من الاتتفاع بالخنزير فيما سوي اللحم

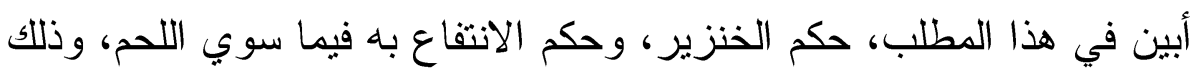
من خلال فرعين كالتالي: ين فئ

\section{الفرع الأول \\ حكم الخنزير}

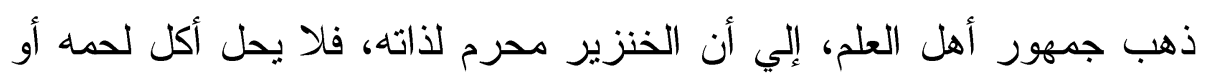

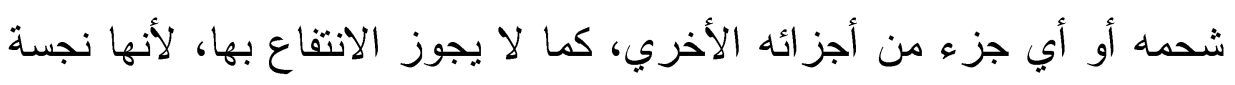




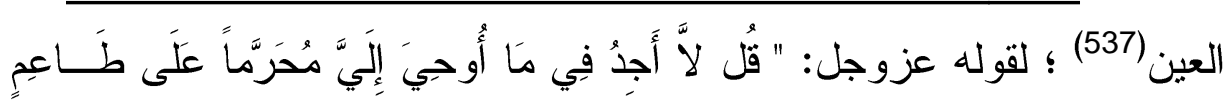

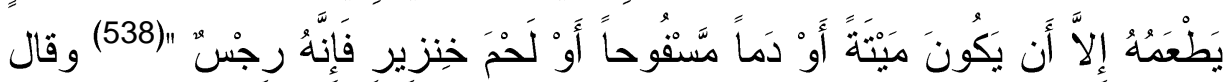

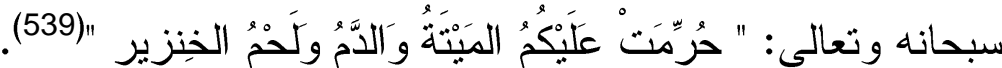

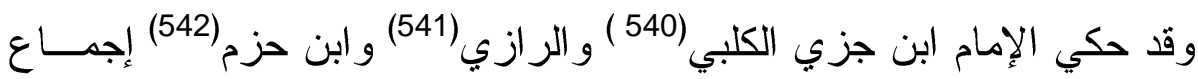
علماء الأمة علي ذلك.

بيد أن العلامة الطاهر بن عاشور ، كان له في هذا التعميم نظر، حيث قال في تفسير الآية السابقة:" و إنما قال تعالي:" ولحم الخنزير" ولم يقل: و الخنزير كما قال:" وما أهل لغير الله به " إلي آخر المعطوفات، ولم يذكر تحريم الخنزير في

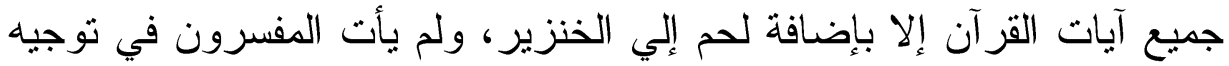
ذللك بوجه ينتلج له الصدر .. ويبدو لي أن إضافة لفظ لحم إلي الخنزير للإيماء

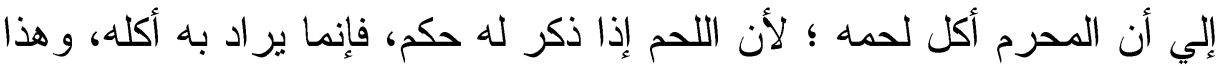

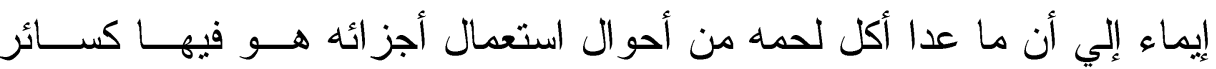

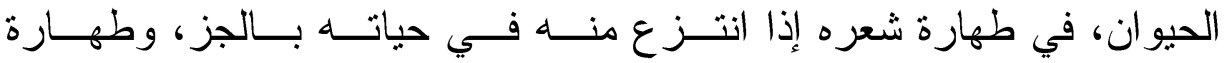

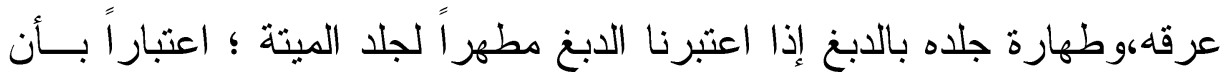

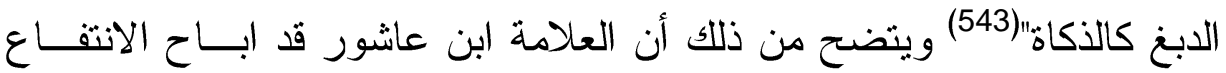

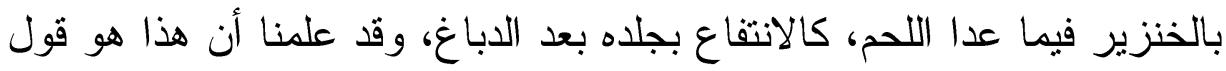

(206/1 206/ شروح الهداية 82/1 وما بعدها، الذخيرة 609/4، الكـافى لابــن

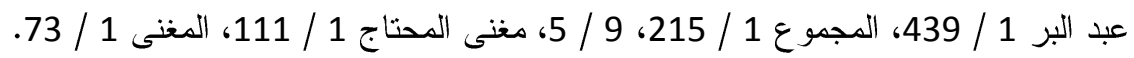

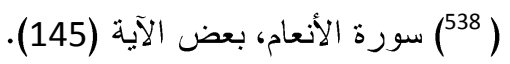

(539) سورة المائدة، بعض الآية (3).

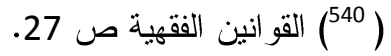

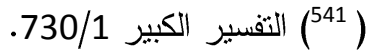
(542) مر اتب الإجماع ص 149.

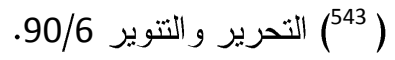




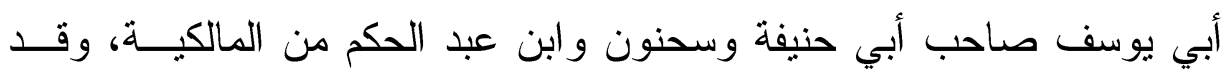
رجحه البحث، وكذا الانتفاع بشعره، مما يدل علي أن هناك مخالفــة لـدعوي الإجماع علي تحريم الانتفاع بالخنزير فيما سوي اللحم. 


\section{الفرع الثاني}

الانتفاع بالخنزير فيما سوي اللحم في الفقه الإسلامي

أعرض في هذا الفرع للانتفاع بالخنزير في الأغذية و الأدوية، و العلاج الطبي الأبياي

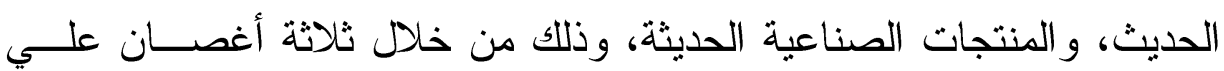

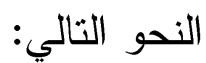

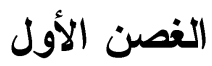

\section{الاتثفاع بالخنزير في الأغذية والأدوية}

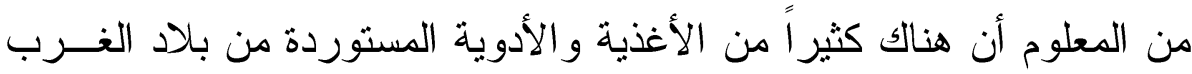

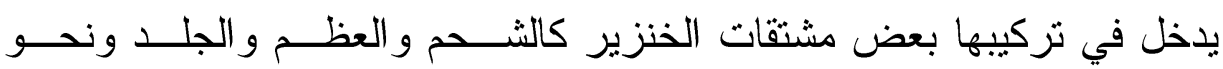

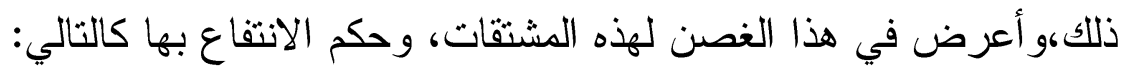

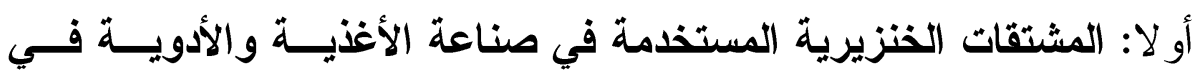

$$
\text { العصر الحديث: }
$$

\section{تتمثل أهم هذه المشتثات الخنزيرية فيما يلي:}

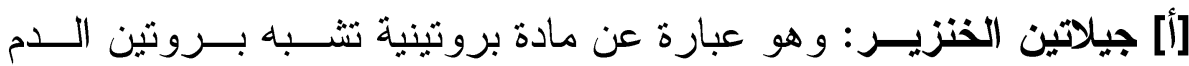

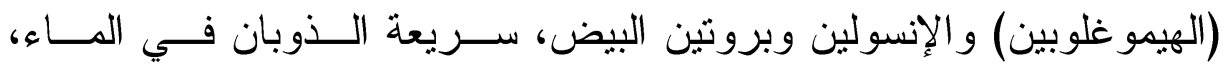
تستخلص من جلد وعظم الخنزير و البقر غالبا(544).

وتستخدم مادة الجيلاتين في كثير من الصناعات الغذائية، ومن أهمها:

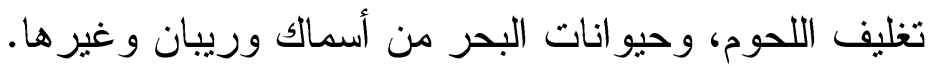
• صناعة المتلجات - كالجيلاتي و الأيس كريم و البوظة - ومنتجات الألبان. • صناعة الحلويات وبعض أنواع اللبان وحبات الحلوي الهلامية.

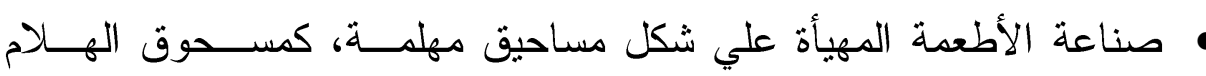
(الجيلي) و البودينغ و غير ها.

$$
\text { (544) د. دمعد الهو اري، الطعام و الثر اب بين الحلال و الحر ام ص } 8 .
$$




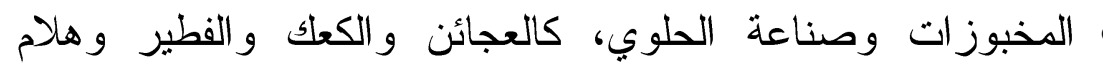
(جيلي) حفظ الفاكهة.

تجهيز أقوات المرضي الذين أجريت لهم جراحة في القناة الهضمية

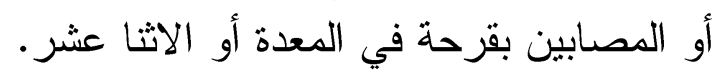

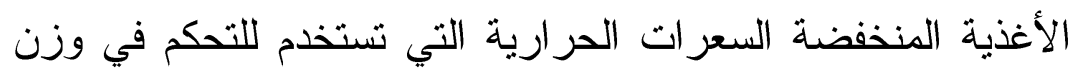

الجسم.

كما تستخدم مادة الجيلاتين في كثير من الصناعات الاوائية ومنها:

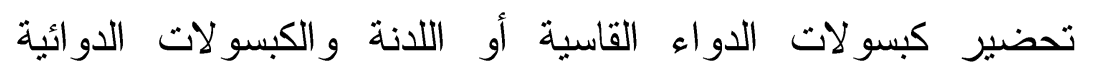

الاقيقة.

إنتاج أقراص المص القاسية أو الطرية المحلة بالفيتامينات و المواد

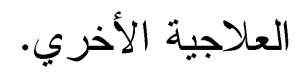

إنتاج الأقراص أو الملبسات الدوائية التي تغلف بالجيلاتين لمنع الذوبان السريع لها.

تحضير اللبوسات الثرجية والمهيلية ؛ لأنه يذوب بفعل حرارة

• يستخدم الجيلاتين كبديل أو موسع للبلازما (لاستخدامه عند الحاجة إلي تعويض حجم الدم الناقص). • يستخدم كموقف لنزيف الدم في العمليات الجراحية، وكمضاد للتهيج في الحروق و غير ها من إصابات الجلد (545).

[ب] إنفحة الخنزير: فتعقد كثير من الأجبان في العــالم الغربـي بالإنفحــة المستخرجة من معدة الخنزير ، و المعروفة بالببسين (546).

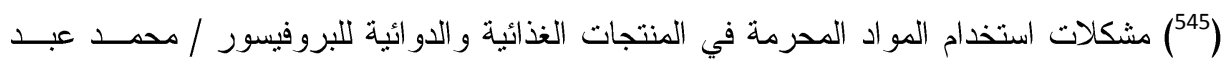

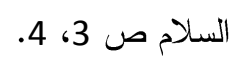
( الطعام و الثر اب بين الحلال و الحرام ص 10، 11 (10. 
[ج] مادة الكوليسترول: فتستخلص هذه المادة من الأحبال الفقرية للماشية بمــا فيها الخنزير، وكذلك من الدهون الموجودة في صوفها باستخدام المذيبات،

وتستخدم في إنتاج الكثير من الكبسولات الصغيرة لتكسبها صلابة(547). [د] مادة الليستين: فتستخلص هذه المادة من البقر و الغنم و الخنزيــر وصــفار

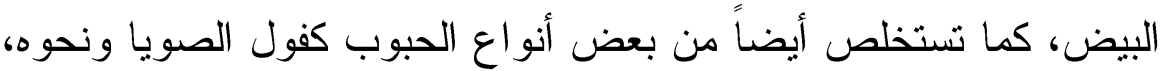

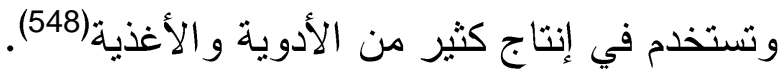

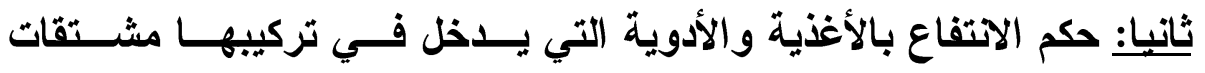

بالنسبة لحكم الجيلاتين:فنظر الما قرره المختصون من علماء الكيمياء الحيوية

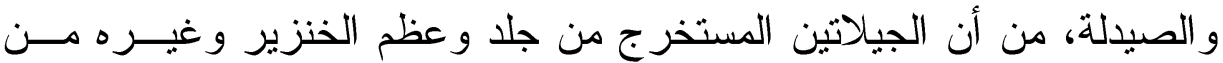
الحيو انات، تجري عليه عمليــة كيميائيــة تــؤدي إلـــي اســـــالته بـــالمعني الشرعي (549)؛ حيث تتقلب معها عين الجلا و العظم المحكوم عليـهـ بالنجاســة

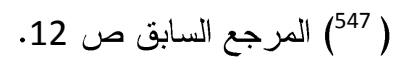

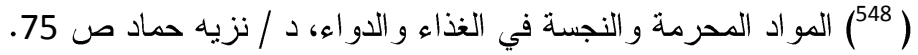

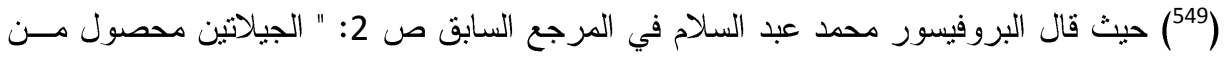

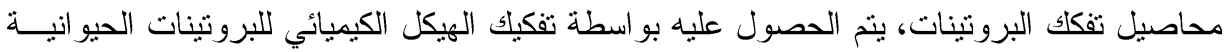

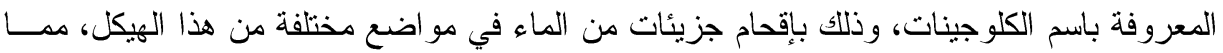

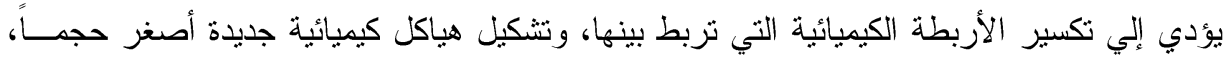

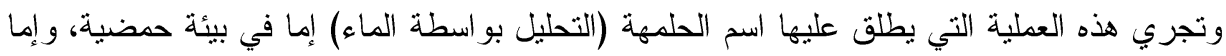

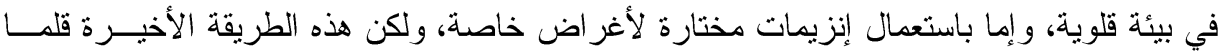

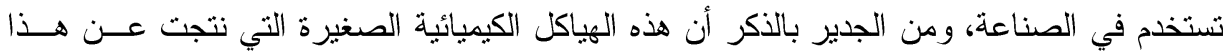

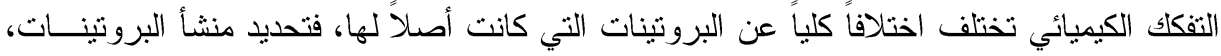

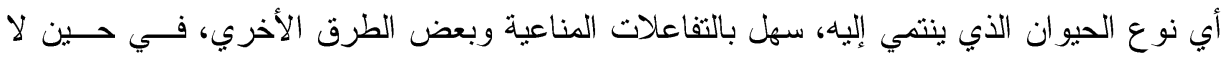

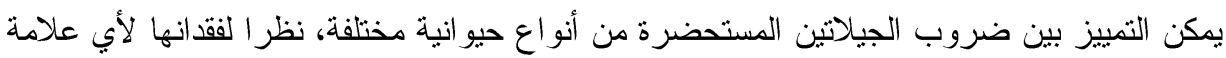

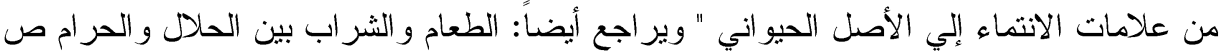




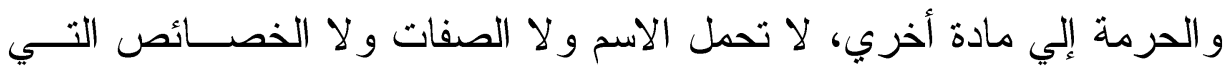

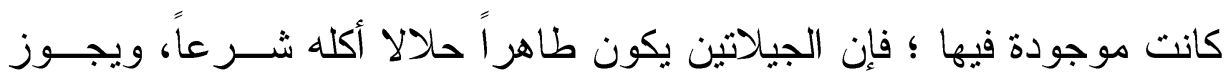

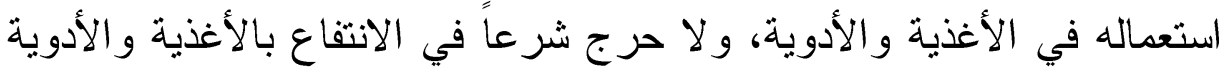

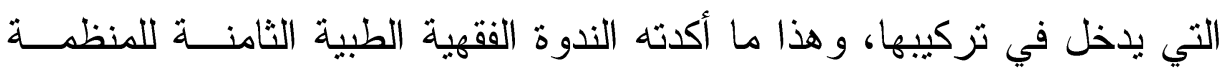

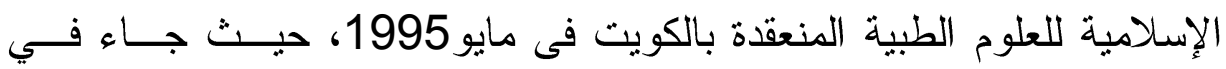

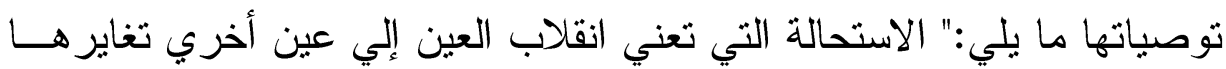

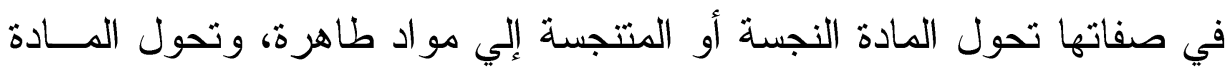

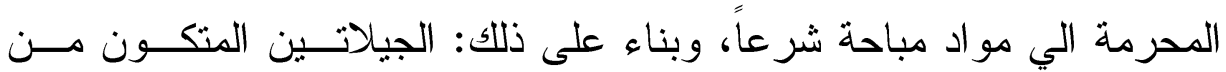

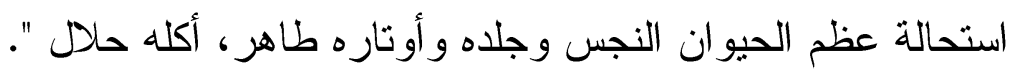

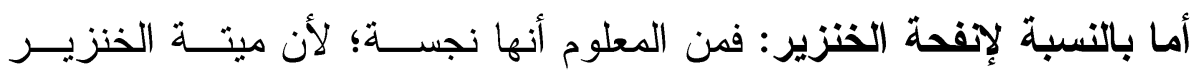

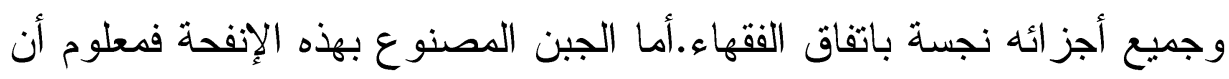

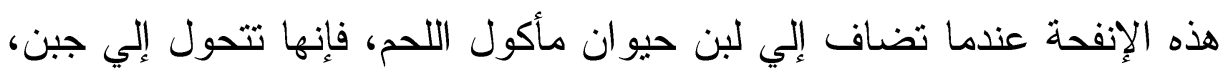

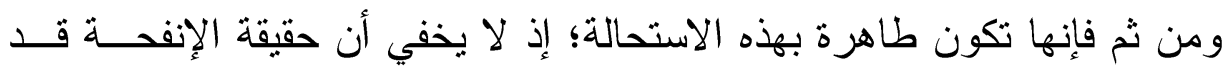

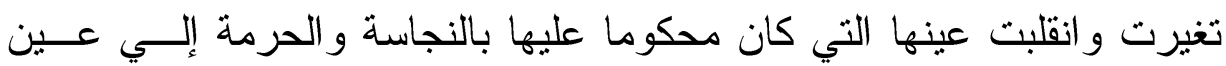

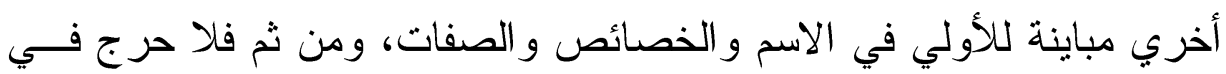
تتاول الجبن المنعقد بإنفحتها شرعاً.

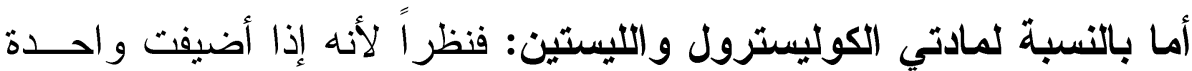

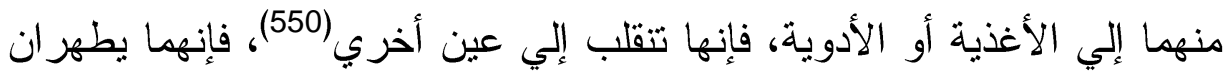

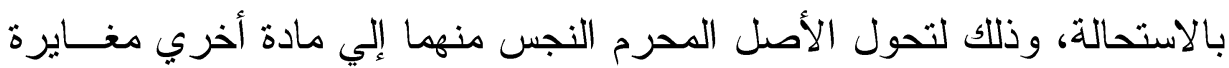

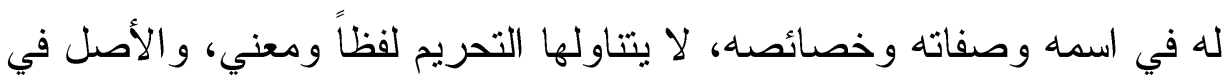

$$
\text { ( الطعام و الثر اب بين الحلال و الحرام، د. محمد الهوي ص } 10 \text { - } 12 .
$$


الأعيان الطهارة(551)، وأساس ذلك أن تحلل المواد المحرمسـة و النجســة إلــي

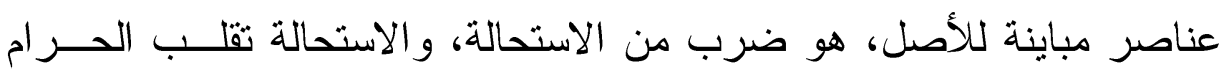

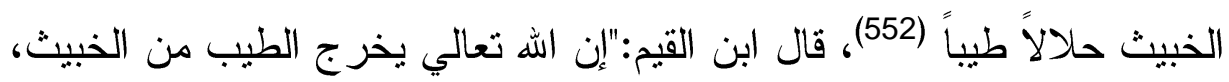
و الخبيث من الطيب، ولا عبرة بالأصل، بل بوصف الشئ نفسه، ومن الممتنع بقاء حكم الخبيث، وقد زال اسمه ووصفه، و الحكم تابع للاسم، دائر معه وجوداً و عدما "(553).

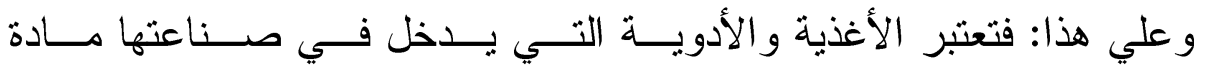
الكوليسترول أو الليستين حلال طاهرة مباحة شرعا. وقد صدرت توصية من الندوة الفقهية الطبية التاســعة للمنظمـــة الإســـلامية

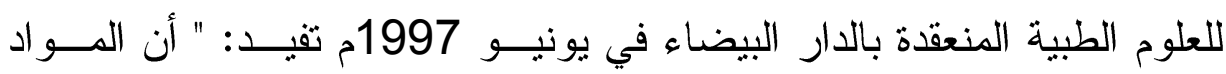

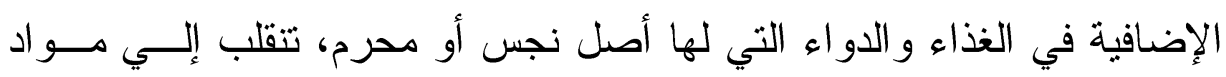
مباحة شر عاً بالاستحالة". الغصن الثاني

\section{الاتتفاع بالخنزير في العلاج الطبي الحديث}

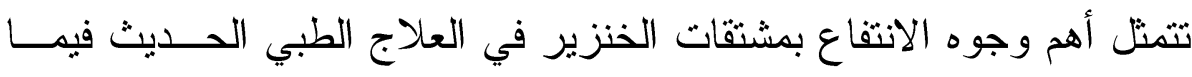
يلي:

\section{[أ] الاتتفاع بإنسولين الخنزير لعلاج مرضي السكر:}

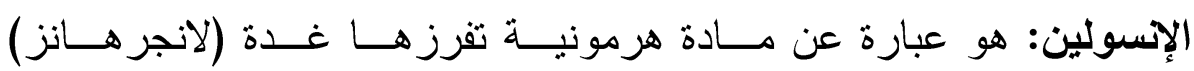
بالبنكرياس، وتقوم هذه المادة بحرق المو اد الكربو هيدر اتية وتحويلها إلي ثــاني

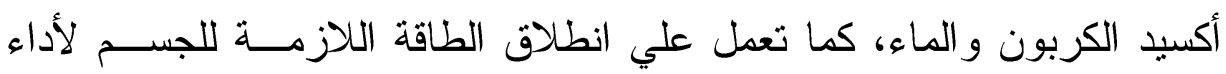

$$
\begin{aligned}
& \text { (551) مو اهب الجليل 122/1. }
\end{aligned}
$$

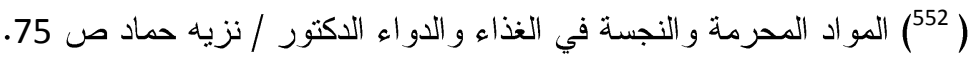

$$
\begin{aligned}
& \text { (14/2) إعلام الموقعين. }
\end{aligned}
$$


وظائفه، ويترتب علي فقدان هذه المادة أو نقصانها عن الكمية اللازمــة إلـي

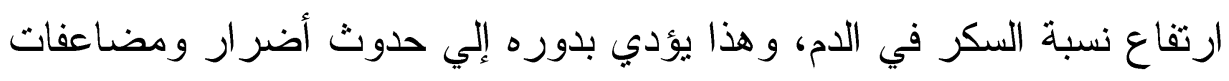

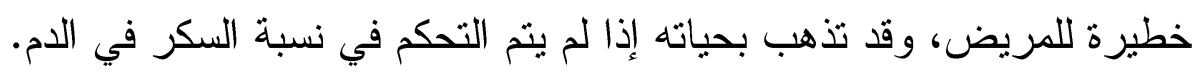

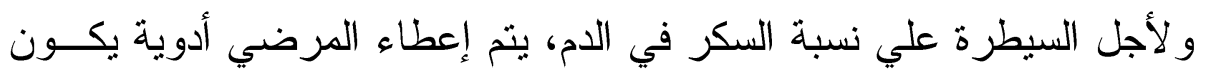

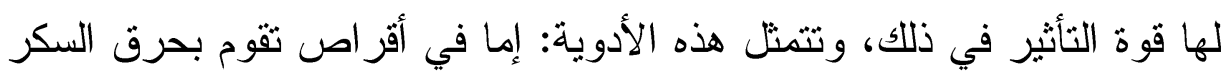

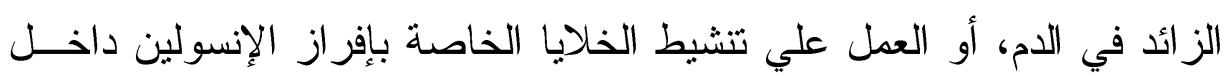

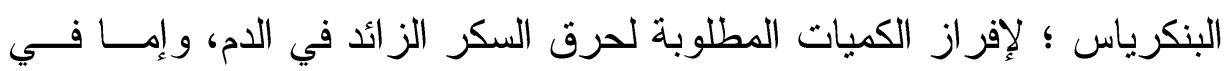
مادة الإنسولين التي تتناول بطريق الحقن تحت الجلد، ويتم استخر اج هذه المادة من غدة بنكرياس الخنزير، وقد تم في الآونة الأخيرة تحضير إنسولين بثــري

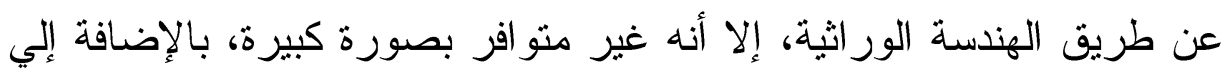
ارتفاع ثمنه(554).

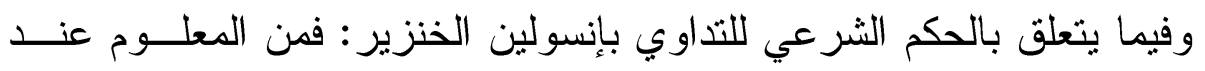

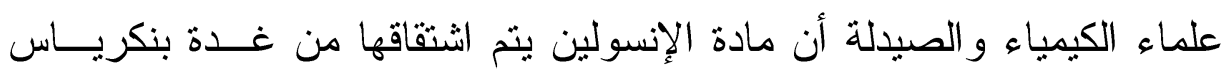

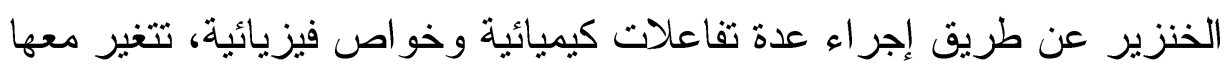

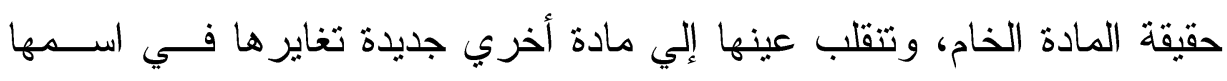

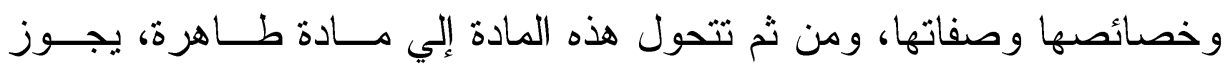
التداوي بها شرعاً. قال ابن حزم: " الحرام إذا بطلت صفاته التي بها سمي بذللك الاسم الذي بـــه نص علي تحريمه، فقد بطل ذلك الاسم عنه، و إذا بطل ذللك الاسم سقط التحريم ؛ لأنه إنما حرم ما يسمي بذلك الاسم "(555).

$$
\begin{aligned}
& \text { (554) المو اد المحرمة والنجسة في الغذاء و الدواء، د / أحمد رجائي الجندي ص 1010، 1017، } 15 \text { (105 . }
\end{aligned}
$$

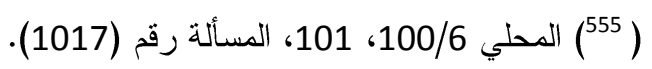


وقد صدرت توصية من الندوة الفقهية الطبية الثامنة للمنظمة الإسلامية للعلوم

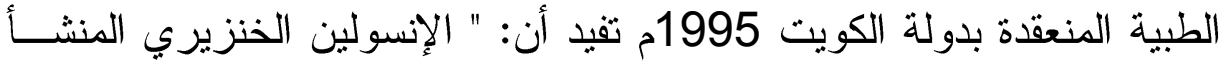
يباح لمرضي السكر التداوي به للضرورة وبضو ابطها الشرعية " بيد أنني أتفق

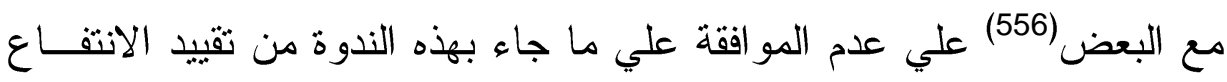
بالإنسولين الخنزيري بحالة الضرورة ؛ إذ لا يوجد ما يدعو إلي منّل هذا التقييد بعد تحقق الاستحالة بمفهومهما الثرعي، في اثــقاق الإنســولين مــن غــدة

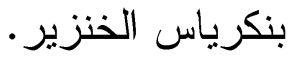

\section{[ب] الاتتفاع بجلد الخنزير في عمليات الترقيع الجلدي:}

قد يحدث أن يفقد شخص جزءاً من جلا جســمه نتيجــة استنئســال الأورام الجلدية أو الالتهابات الشديدة، أو بسبب تعرضه لحــادث سـيارة أو حريـق، وتتطلب مثل هذه الحالات تغطية أكبر مساحة ممكنة من القدر المفقــود مــن الجلد، و هوما يعرف بالترقيع الجلدي ؛ لحمايته من التلوث، ومنع تبخر السوائل منه، و إلا تعرض المصاب - خاصة في حالة الحريق - لأضرار ومضاعفات خطيرة قد تؤدي بحياته(557). و إذا كان الأمر كذلك، فما هو الحكم الشرعي في ترقيع الجلا في مثل هـــه

$$
\text { الحالات بجلد الخنزير ؟ إن }
$$

أقول: إذا وجدت رقعة جلدية مباحة شرعاً، كتلك التي يتم نقلهــا مــن بـــن المصاب إلي الموضع أو المو اضع المصابة من بدنه، أو التي يتم نقلها من بدن شخص متبرع إلي بدن المصاب، فإنه لا يجوز في هذه الحالة اســتخدام جلــد

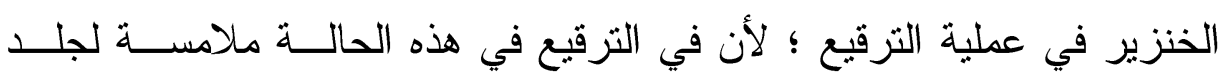

$$
\text { ( المو اد المحرمة و النجسة في الغذاءو والدو اء، د. نزيه حماد ص 786 75، } 79 .
$$

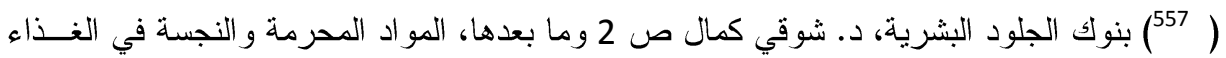

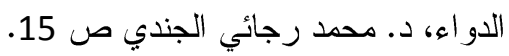


الخنزير ، و هو نجس باتفاق الفقهاء كما بينت قــبلاً (558)، ولا يجــوز ملامســة النجاسات لبدن المسلم.

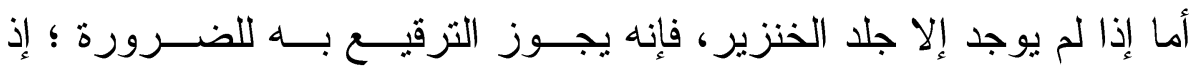

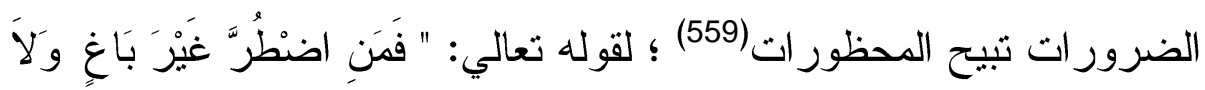

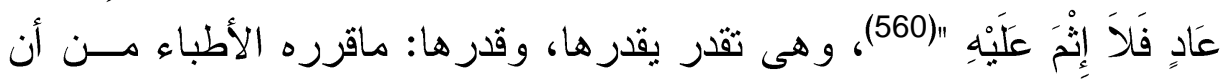

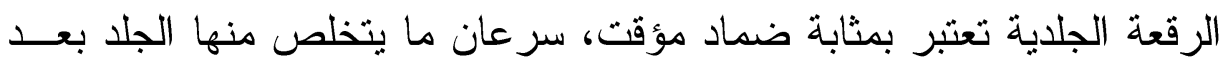

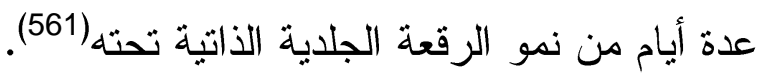
يؤكد ذلك ما جاء في توصيات الندوة الفقهية الطبية الثامنة للمنظمة الإسلامية

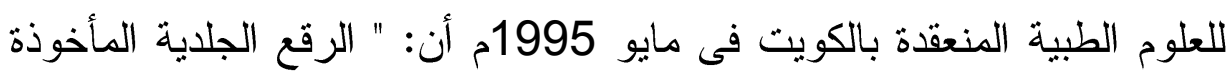
من الكلب أو الخنزير لا يجوز استخدامها إلا عند عدم وجود البــديل الجـائز شرعاً، وعند الضرورة، شريطة أن تكون مؤقتة ". الغصن الثالث

\section{الاتتفاع بالخنزير في المنتجات الصناعية}

أعرض لذلك من خلال المسائل الآتية: [أ] الانتفاع بجلا الخنزير المدبوغ:

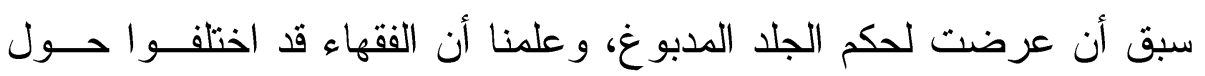

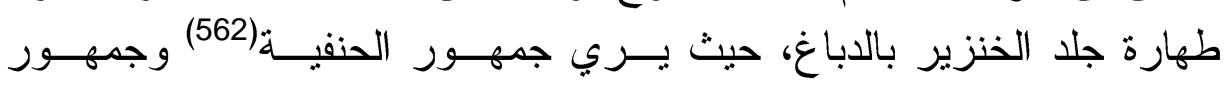

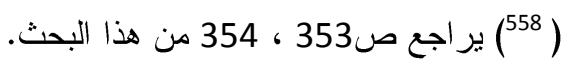

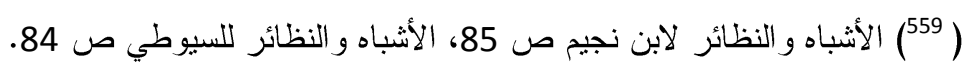

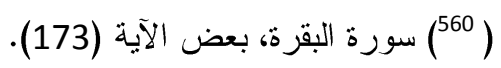

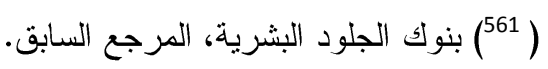

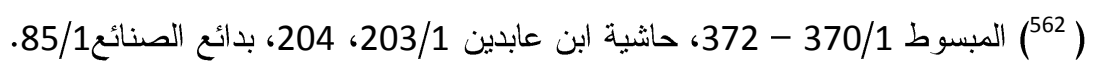


المالكبة(563)، و الثافعية(564)، و الحنابلة(565)، أن جلد الخنزير لا يطهر بالدباغ مطلقا، وقد سبق عرض أدلتهم ومناقشتها(566). ويري أبو يوسف صاحب أبي حنيفة(567)، وسحنون و ابن عبد الحكــم مسنـ

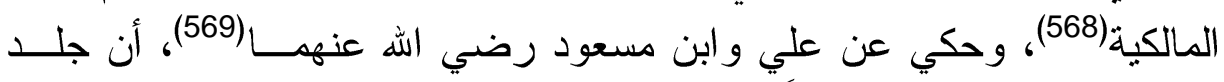
الخنزير يطهر بالدباغ مطلقا، وقد سبق عرض أدلتهم(570)، وهو الرأي الراجح كما بين البحث سلفاً (571). كما عرضت قبلاً - أيضًا - لحكم الانتفاع بالجلد المدبوغ، و علمنا أن الفقهاء

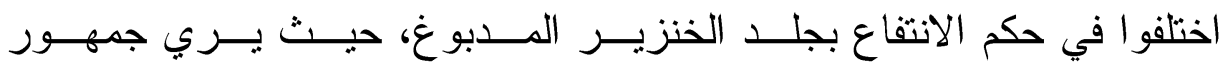
الحنفية(572)، و المشهور عند المالكية(573). و الشافعية(574)، و الإمام أحمد في رواية وظاهر المذهب(575)، أنه لا يجـــوز الانتفاع بجلد الخنزير المدبوغ مطلقا، وقد سبق عرض أدلتهم ومناقشتها(

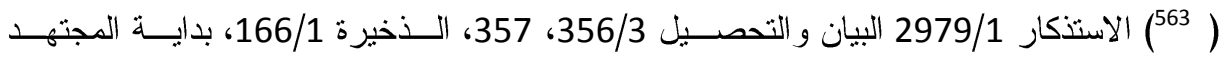
$.104 / 1$

(564) المجموع 215/1، الحاوي الكبير 56/1، روضة الطالبين 151/1، 151/، المهذب 9/1،

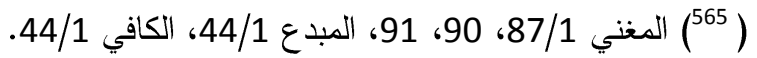
(566)

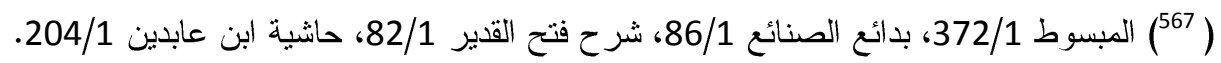

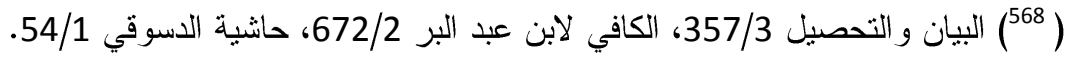

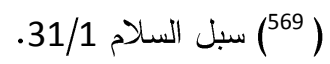
(570) (ير اجع ص 332 - 336 من هذا (البحث.

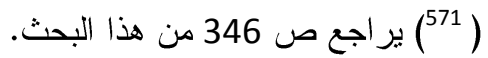

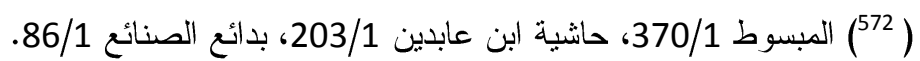

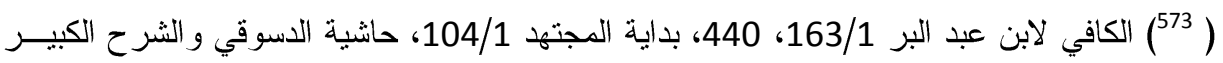

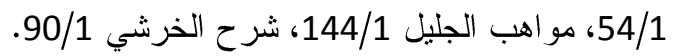

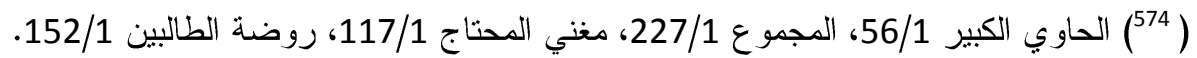

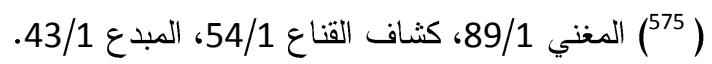

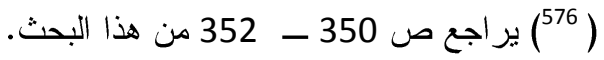




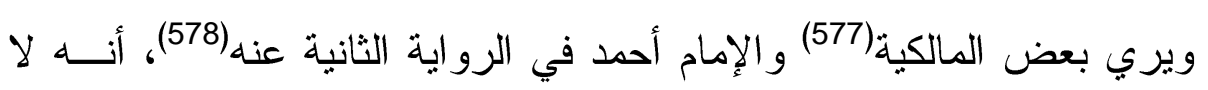
يجوز الانتفاع بجلد الخنزير المدبوغ إلا في البابسات فقط، وقد سبق عــرض أدلتهم ومناقشتها(579). ويري أبو يوسف صاحب أبي حنيفة(580)، و الإمام مالكك فــي رو ايـــة عنــه،

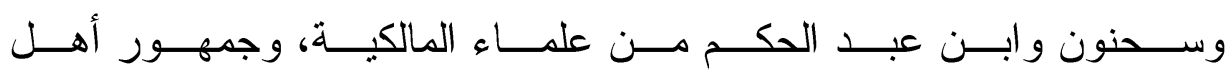
المدينة(581)، و الثوري و الأوز اعي و إسحاق بن راهوية و الحسـن البصــري، واءكن وجمهور البصريين و الكوفيين (582)، أنه يجوز الانتفاع بجلد الخنزير المــدبوغ مطلقا سواء في البابسات أو في المائعات - وقد سبق عرض أدلتهم(583) وهو الر أي الراجح كما بين البحث سلفاء(584). وبناءً علي ذلك: فلا حرج شرعاً في الانتفاع بجلد الخنزير المدبوغ مطلقـاً،

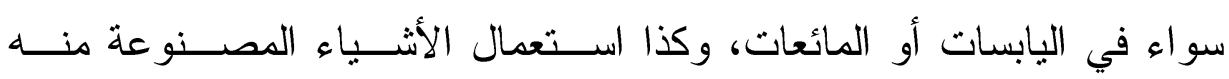
كالملابس و الحقائب و الأحذية و المفروشات و عجل السيار ات ونحو ذلك.

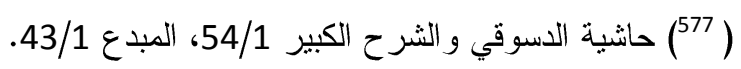
(578) (المغني، كثاف القناع، المبدع، المصادر السابقة.

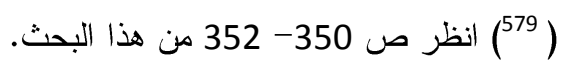

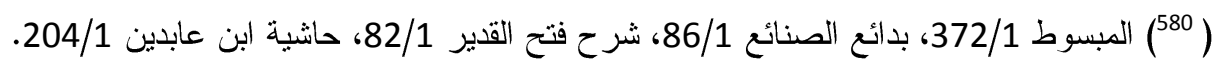

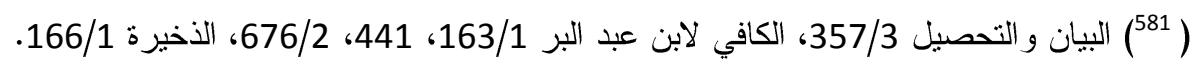

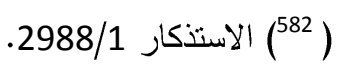

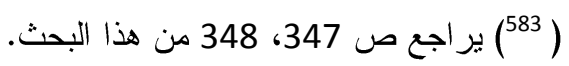
(584) بر اجع ص 352، 353 من صن هذا البحث. 


\section{[ب] الاتتفاع بشعر الخنزير:}

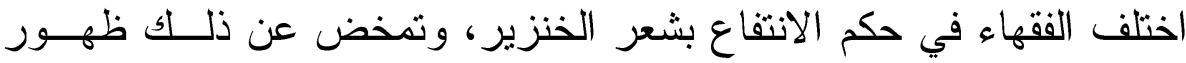

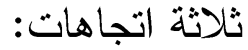

الاتجاه الأول: يري أنصاره أنه يجوز الانتفاع بشعر الخنزير للخرز فقط.

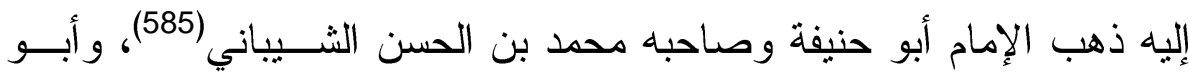

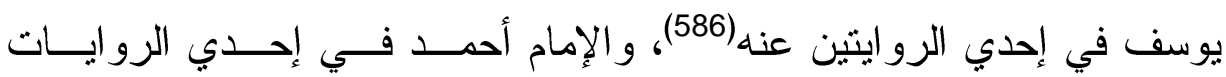
عنه(587)، وحكي عن الإمام الأوز اعي (588).

وقد استخل أصحاب هذا الاتجاه علي ما ذهبو ا إليه بالمعقول من وجهين:

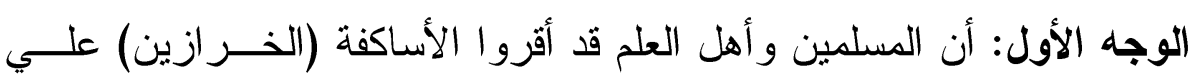
استعمال شعر الخنزير في الخرز، من غير نكير ظهر منهم عليهم، فكان هـــا إجماعاً نهم علي جواز الانتفاع به علي هذا الوجه (589).

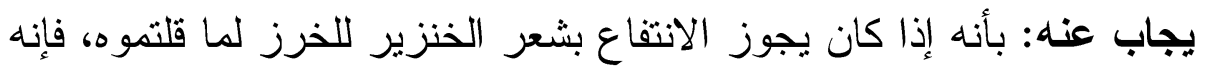

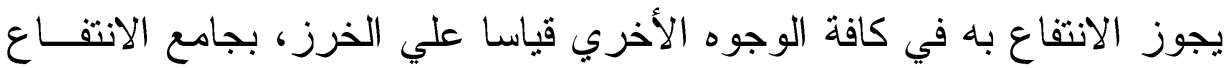
في كل.

الوجه الثاني: أن الحاجة ماسة إلي الخرز بشعر الخنزير ؛ لأن غيره لا يقوم

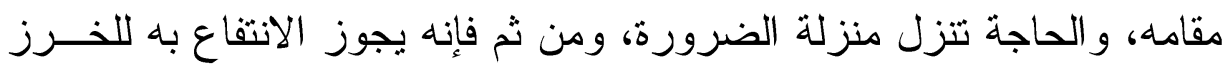
فقط

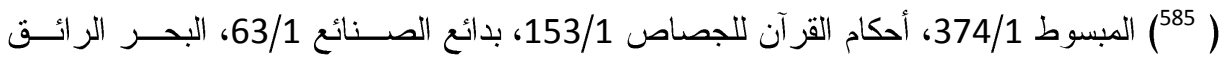
113/1، حاشية ابن عابدين 206/1.

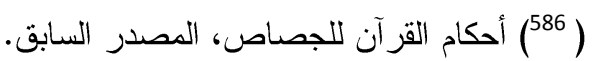
(587) أحكام القر آن للجصاص، المصدر السابق، تفسير الفخر الرازي 730/1.

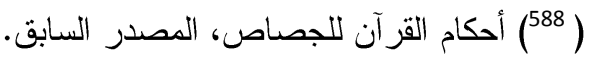
(589) أحكام القرآن للجصاص، المصدر السابق، تفسير الفخر الرازي 730/1.

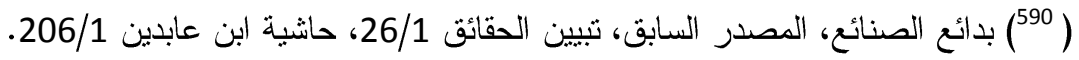
doi: 10.12816/0004230 
يناقش: بأن الناس في زماننا استغنوا عن شعر الخنزير في الخرز، ومن ثم

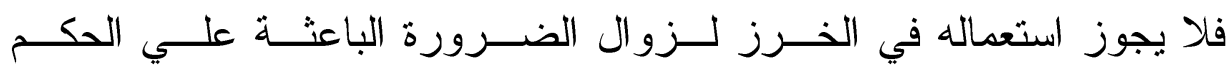
بطهارته (591).

\section{الاتجاه الثاني:}

يري أنصاره أنه يجوز الانتفاع بشعر الخنزير مطلقاً ؛ لأنه طاهر، سواء جز الاهز

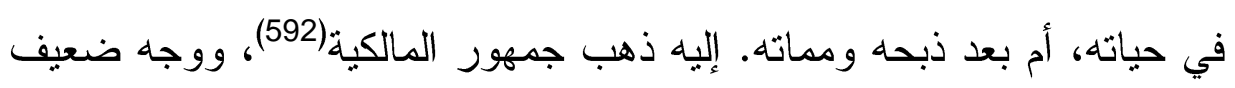

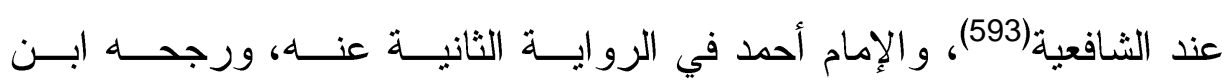
تيمية(594).

\section{وقد استدل أصحاب هذا الاتجاه علي ما ذهبوا إليه بــالمعقول، فقـالوا: إن}

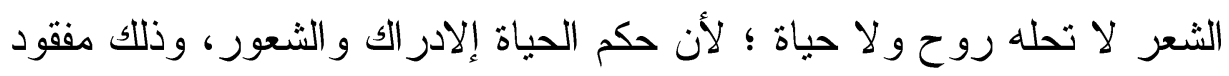

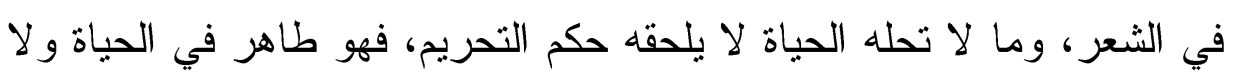

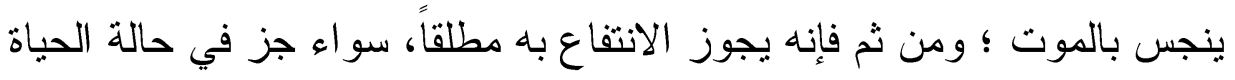

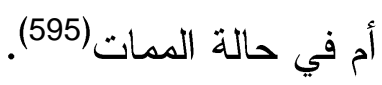
الاتجاه الثالث: يري أنصاره أنه لا يجوز الانتفاع بشعر الخنزير مطلقاً. إليه

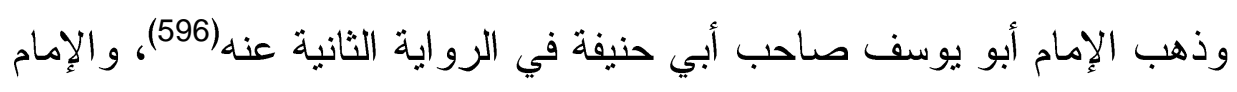

\footnotetext{
(1) (لاثية ابن عابدين، كالمصدر السابق.

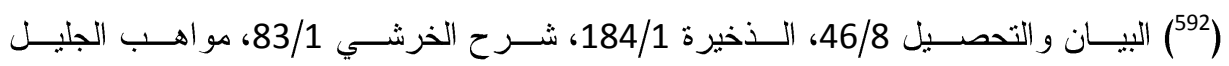
125/1، التاج و الإعليل 126/1.

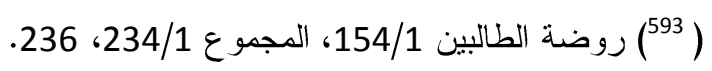

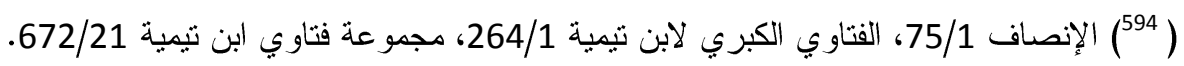

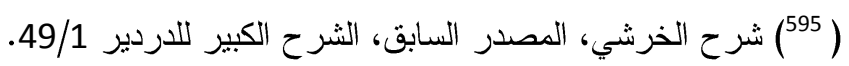

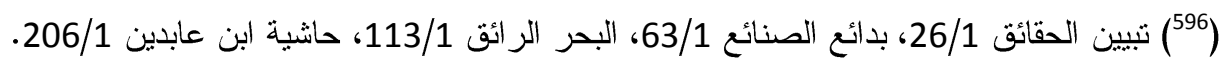
365
} 


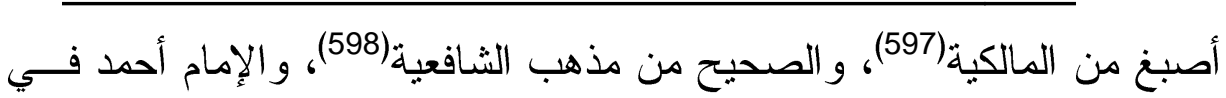

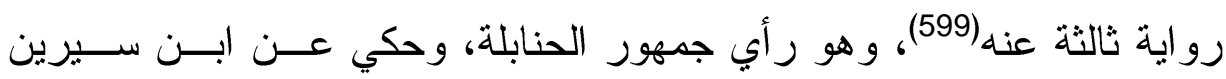
و الحكم وحماد و إسحاق (600).

وقد استدل أصحاب هذا الاتجاه علي ما ذهبوا إليه بــالمعقول، فقــالوا: إن

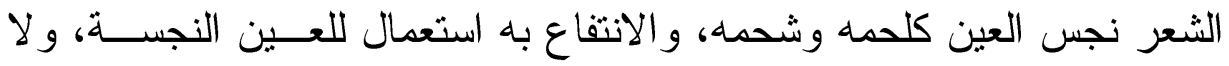
يسلم من التجيس بها، فحرم الاتثفاع بها كجلده(601).

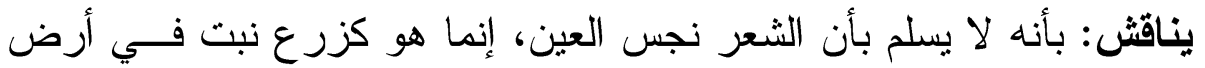

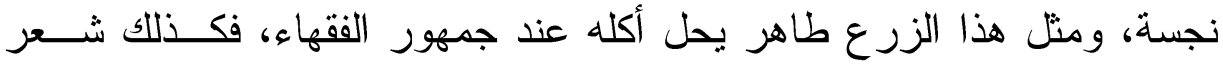
الخنزير يحل الانتفاع به مطلقاً.

الاتجاه الراجح: بالنظر في الاتجاهات السابقة وأدلتهم، ألحظ أنه لا يوجد دليل

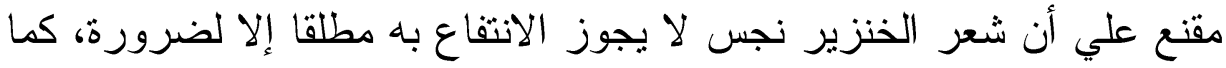

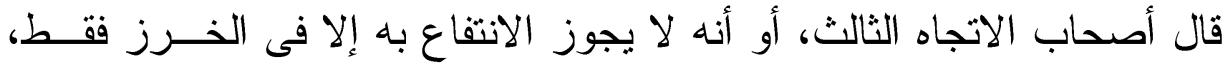

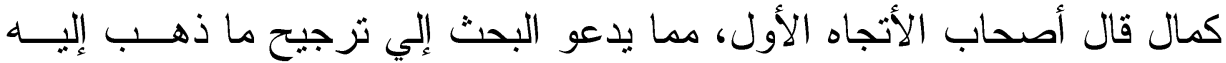
أصحاب الاتجاه الثاني ؛ حيث القول بطهارة شعر الخنزير مطلقاً، وذلك: " لأن

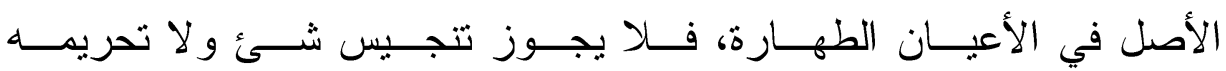
إلا بدليل "(602).

(597) البيان و التحصيل، الذخيرة، المصدرين السابقين.

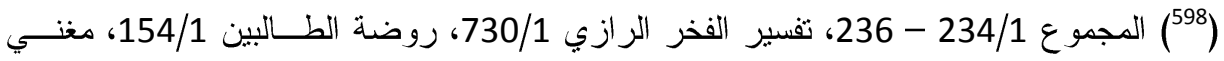

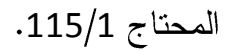

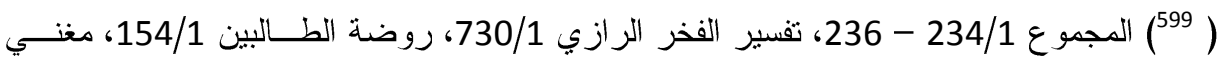
المتاج 115/1.

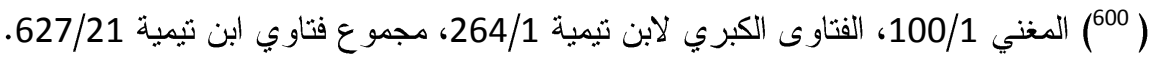

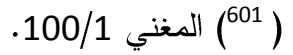
(3602) الفتاوي الكبري لابن تيمية، مجمو عة فتاوى ابن تميمة، المصدرين السابقين. doi: 10.12816/0004230 
مجلة الدراسات التربوية والانساتية _ كلية التربية ـ جامعة دمنهور ـ المجلد الخامس العدد(4)- الجزعالثالث- لسنة 2013

ومن ثم: فشعر الخنزير وجميع المنتجات التي استخدم فيها، يجوز الانتفـــاع

بها شر عاً. 


\section{[ج] الاتتفاع بالصابون المصنوع من شحم الخنزير:}

من المعلوم دخول الزيوت و الثحوم في صناعة الصابون، وقد دعا انخفاض بون

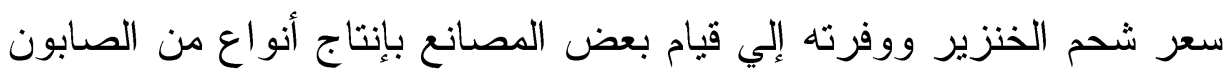
أضيف إليه شحم الخنزير (603). وقد بينت قبلاً أن شحم الخنزير نجس كلحمه باتفاق الفقهاء، أما عن استخدامه

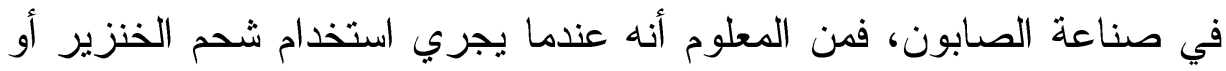
الميتة في صناعة الصابون، تجري عليه عملية استحالة بالمعني الشرعي،حسب لهب ما ذكره البحث في تكييف الاستحالة فقها. - حيث تتغير حقيقة الثحم المحــرم

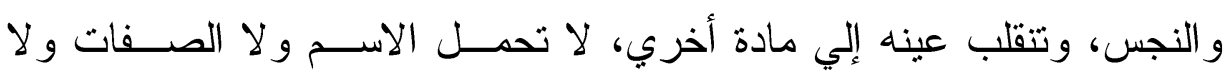
الخصائص التي كانت موجودة فيه، وبناءً علي ذللك: فالصابون المتكون مسنـ لهن استحالة شحم الخنزير طاهر ، جائز استعماله شرعاً. وقد أدرك ابن عابدين هذا المعني فقال: " لو وقع كلب في قــدر الصــــابون فصار صابوناً، يكون طاهراً، لتبدل الحقيقة "(604). وحكي ابن نجيم في بحره الرائق أن: " جعل الدهن النجس في صابون يفتي

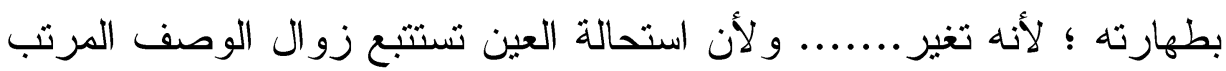
عليها "(605).

وجاء في زاد المعاد، أن الإمام مالك أجاز عمــل الصــابون مــن الزيــــ النجس (606). كما أفتي بذلك أيضاً شيخ الإسلام زكريا الأنصاري، حيث قــال: " ويجــوز اتخاذ الصابون من الزيت النجس "(607).

$$
\begin{aligned}
& \text { (003) مشكلات استخدام المو اد المحرمة في المنتجات الغذائية و الدو ائية ص } 2 \text { - } 4 . \\
& \text { 316/1 310. }
\end{aligned}
$$

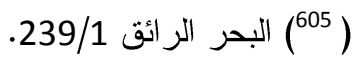

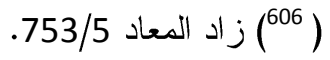

$$
\begin{aligned}
& \text { doi: } 10.12816 / 0004230
\end{aligned}
$$


ومن ثم: فالصابون المصنوع من شحم الخنزير أو من شحوم الميتة طـــاهر ،

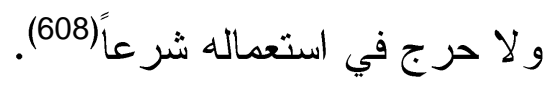

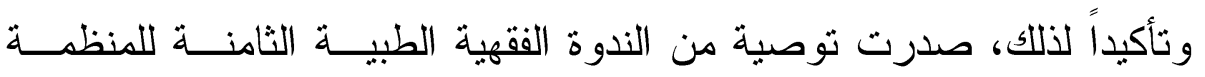

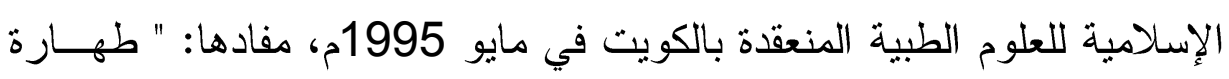

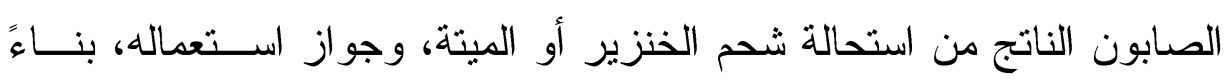

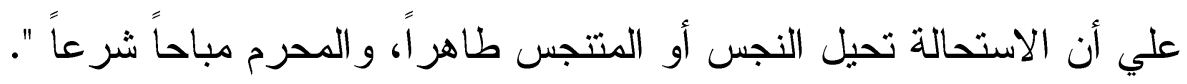
[د] الانتفاع بمعجون الأسنان الأي يدخل في تركيبه شحم الخنزير:

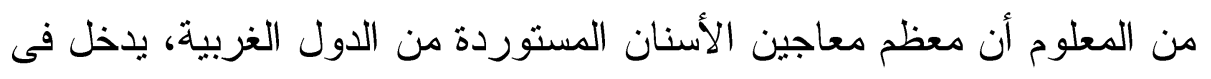

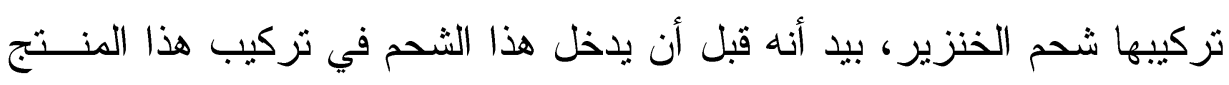

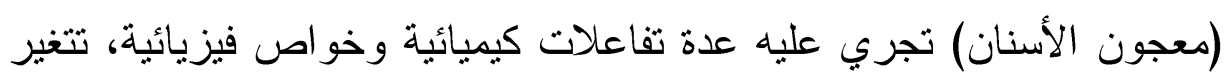

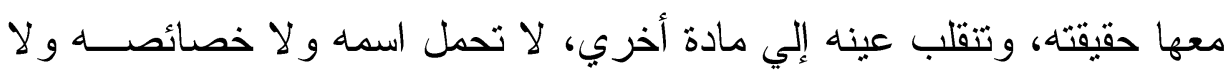

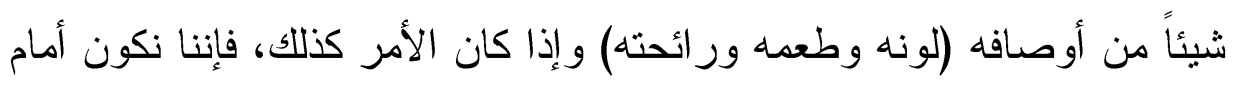

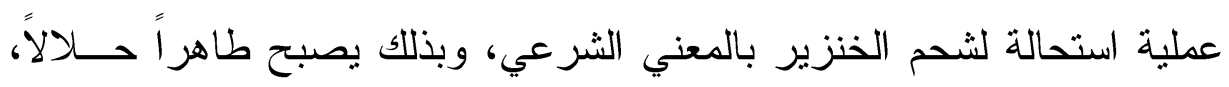
بعد أن كان نجساً محرماً.

قال ابن حزم: " إذا استحالت صفات عين النجس أو الحرام، فبطل عنه الاسم

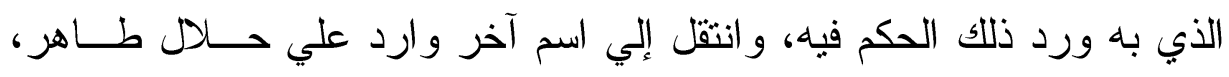
فليس هو ذلك النجس و لا الحر ام، بل قد صار شيئًا آخر ذا حكم آخر "(609).

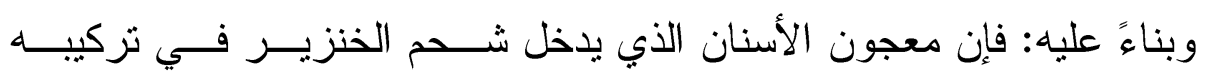

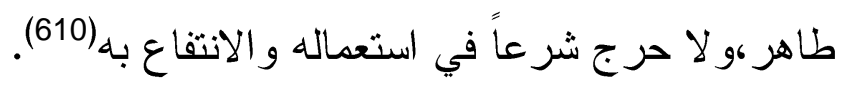

$$
\begin{aligned}
& \text { (607) (أسني المطالب (608/1) }
\end{aligned}
$$

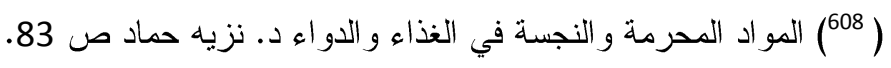

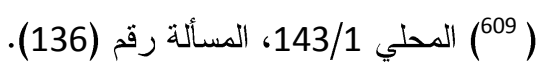




\section{[هـ] الانتفاع بالمر اهم والكريمات المتضمنة لشحم الخنزير:}

من المعلوم أن بعض المر اهم والكريمات المستوردة من البلدان الغربية يدخل في تركيبها شحوم الخنزير. فإذا كان الشحم عند إدخاله في هذه المنتجات، ينم

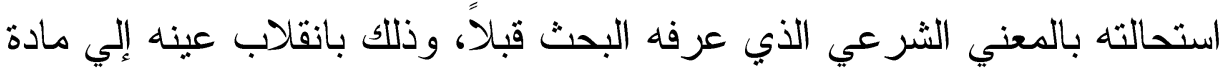

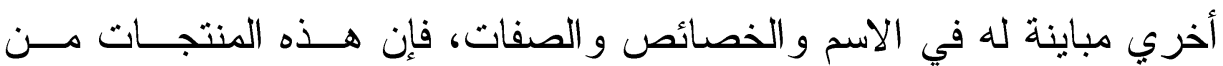

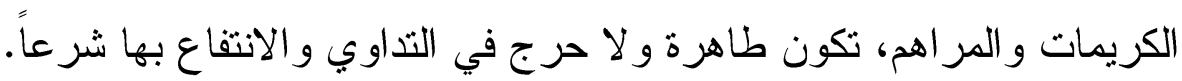

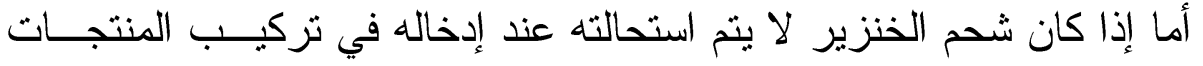

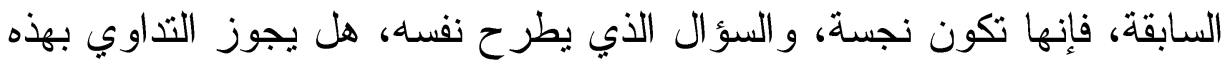

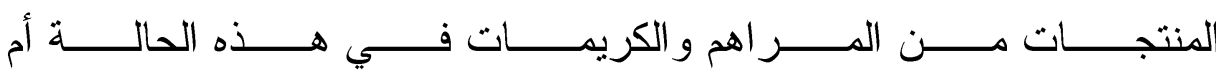

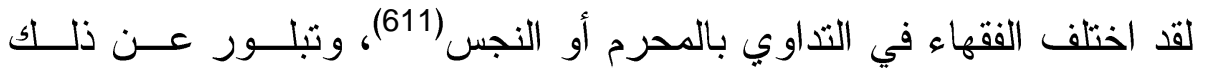
ظهور ثلاثة اتجاهات: - اتهاء

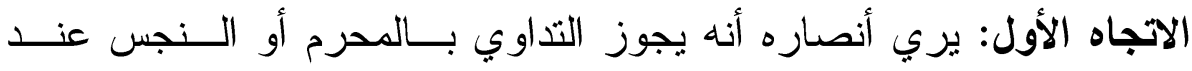

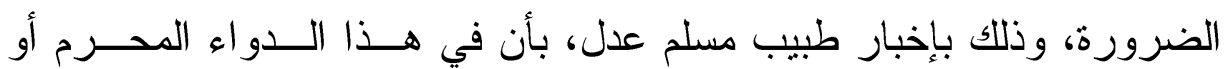
النجس شفاء للمريض، وعدم وجود ما يقوم مقام هذا الدو اء من الطاهر ات. إليه ذهب بعض الحنفية(612)، و الصحيح عند الثافعية وبه قطع جمهور هم (613). وقد استدل أصحاب هذا الاتجاه علي ما ذهبوا إليه بالسنة النبوية المطهرة، و هو ما أخرجه الإمام مسلم عن أنس بن ماللك رضي الله عنه، أنه قال: إن ناساً

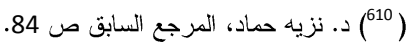
(611) سأتعرض لحكم النداوي بالنجس ماعدا المسكرات ؛ لأن الأخيرة لا ندخل في إطار البحث.

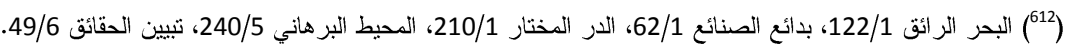

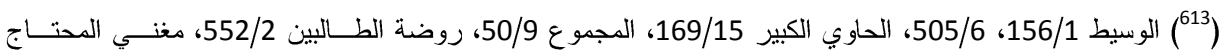
234/4، و هناك وجه شاذ: يرى أنه يجوز التداوي بأبو اب الإبل خاصة، لحديث العرنيين (المجموع، روضـــة الطــالبين،

doi: $10.12816 / 0004230$

(المصدرين السابقين). 


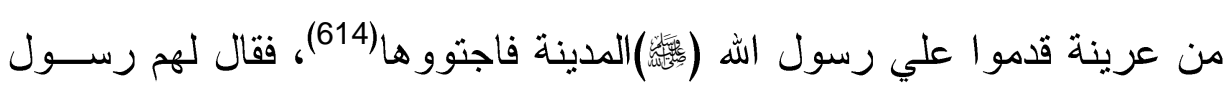

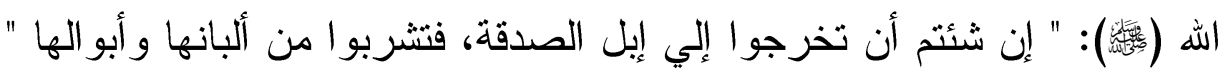
فقعلو ا، فصحو الم (615).

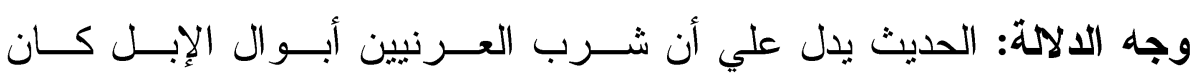

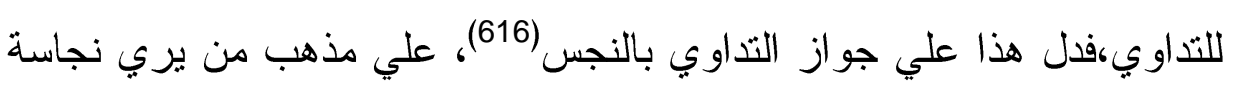

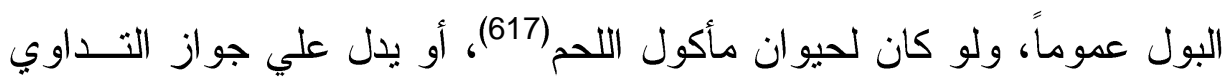

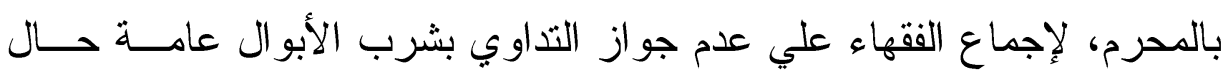
السعة و الاختيار (618).

\section{نوقش هذا الاستدلال من وجوه:}

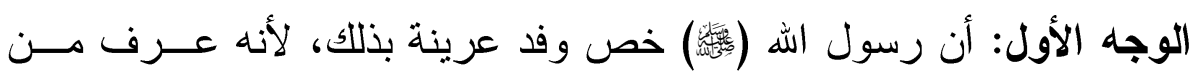
طريق الوحي أن شفاءهم فيه، و لا يوجد مثله في زماننا، وهو كما خص وله الذه الذبير

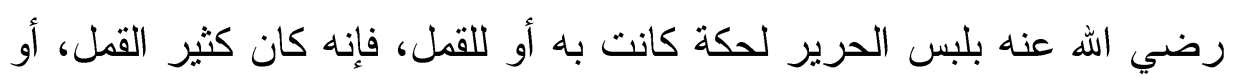

(14) أي: كرهو ها لسقم أصابهم، وهو مشتق من الجوي، أي: داء في الجوف (شرح النــوي علــي صحيح مسلم 154/11). (1269/3) رحيح مسلم، كتاب القسامة و المحاربين و القصاص و الدية، باب حكم الدحساربين و المرتـدين 1269/3، رقم (1671).

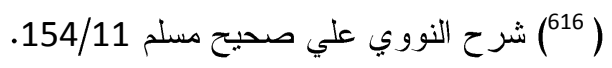
(617) وهم: الإمام أبو حنيفة و أبو يوسف (المبسوط 95/1) و الإمام الثافعي (الحاوي الكبير 243/2)

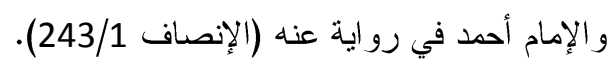

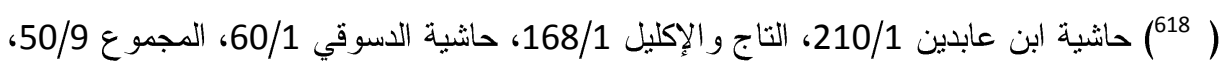
كثاف القناع 200/6. 


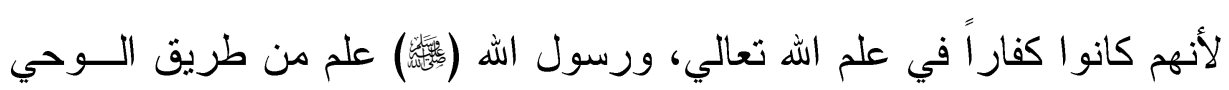
أنهم يموتون علي الردة، و لا يبعد أن يكون شفاء الكافر بالنجس ألهاب (619).

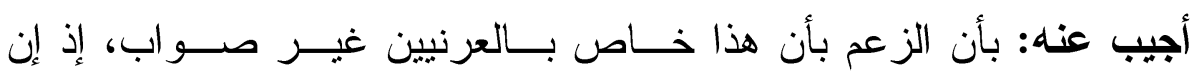

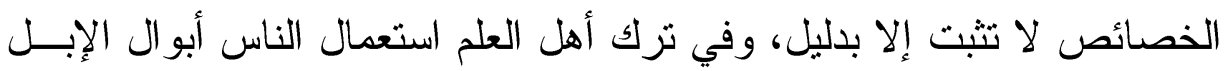
في أدويتهم من غير نكير دليل علي طهارتها(620).

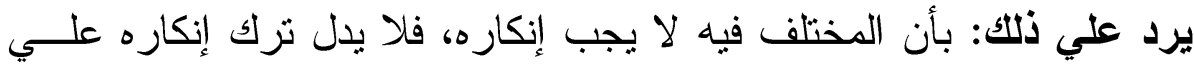
جوازه، فضلاً عن طهارته (621.

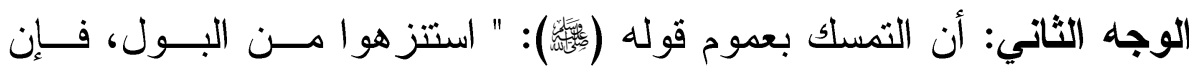

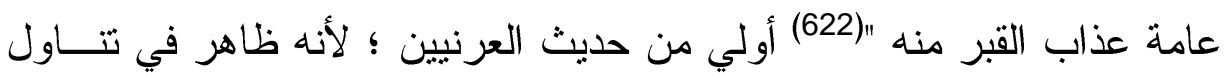

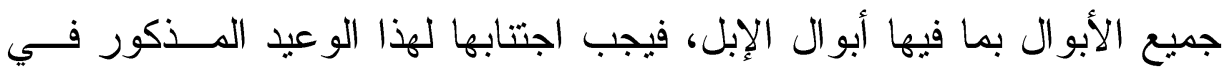
الحديث(623).

الوجه الثالث: إن حديث العرنيين رواه قتادة عن أنس بن مالـــك، وفيـهـ: أن

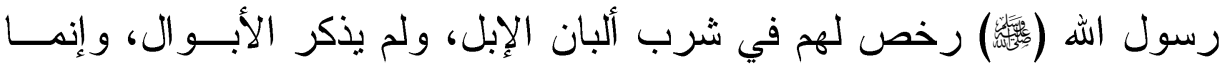

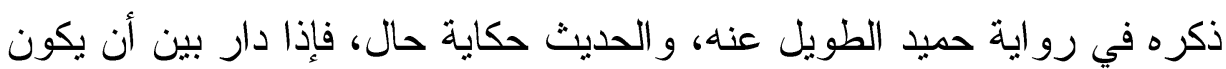

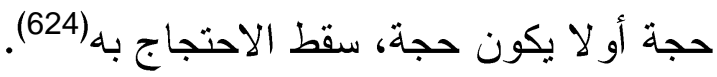

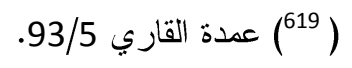

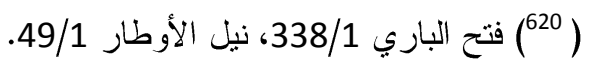
(621) (20) فتح الباري، المصدر السابق.

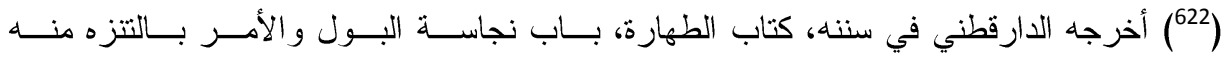

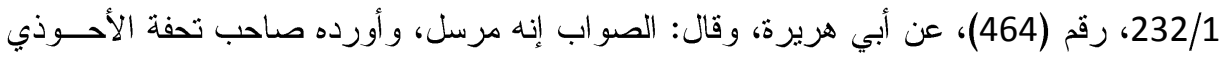

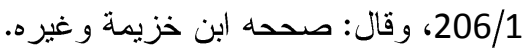
(203/5) عمدة القاري (524) (2024) (المصدر السابق. 
الاتجاه الثاني:

يري أنصاره أنه يجوز التداوي بالمحرم أو النجس في ظاهر الجسد فقط. إليه

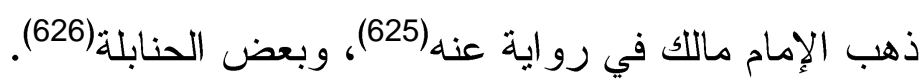

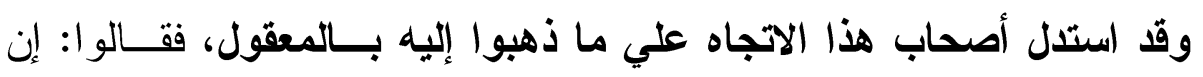

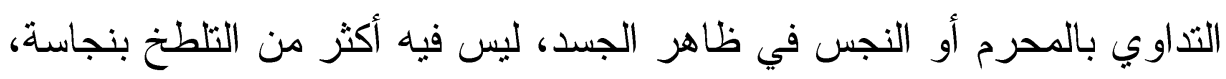
يقدر علي إز التها بعد انقضاء الغرض منها، ومن ثم فيجوز (627).

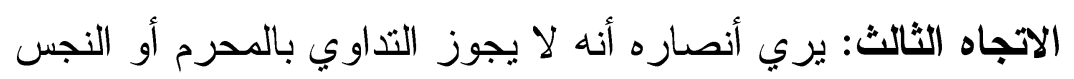

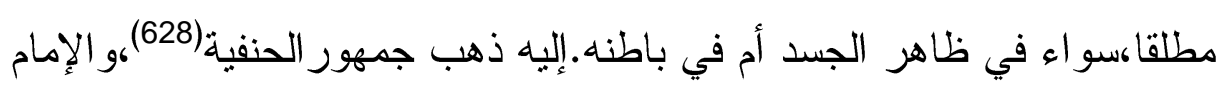

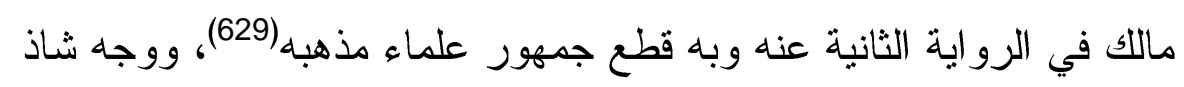
عند الشافعية(630) وجمهور الحنابلة، وهو المعتمد عندهم (631). وقد استدل أصحاب هذا الاتجاه علي ما ذهبوا إليه بأدلة من السنة وأثار الصحابة و المعقول.

(610/2 ) مو اهب الجليل 170/1، التاج و الإكليل 168/1، شرحى ابن نـاجي وزروف علـي الرســالة

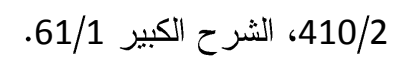

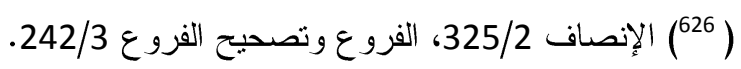

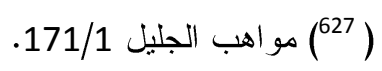

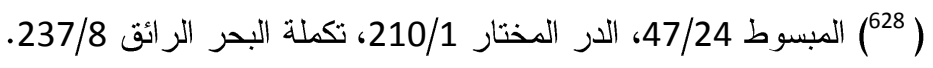

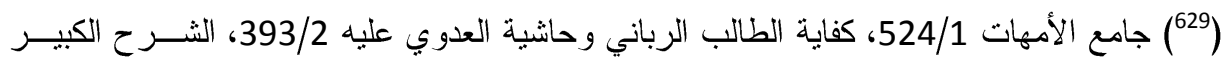

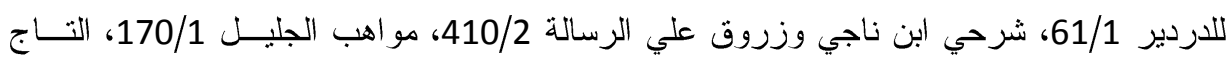
و الإكليل 168/1.

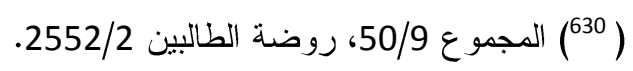
(531) المغني 536/10، الإنصاف 30/2 روضة 325/2، الفروع وتصحيح الفروع 242/3، زاد المعاد 156/4. 373 


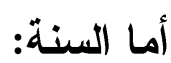

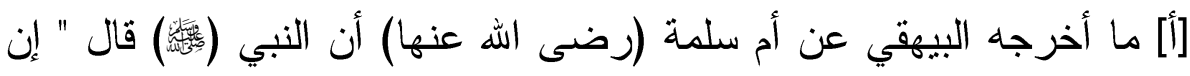
الله لم يجعل شفاءكم فيما حرم عليكم "(632).

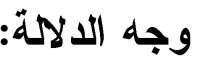

الحديث يدل دلالة واضحة علي أن المحرم أو النجس ليس فيه شفاء للناس ؛ لأن الله تعالي لم يجعله دواء، ومن ثم فلا يجوز التداوي بها. وقد اعترض علي هذا الاستدلال بالاعتر اضات الآتية:

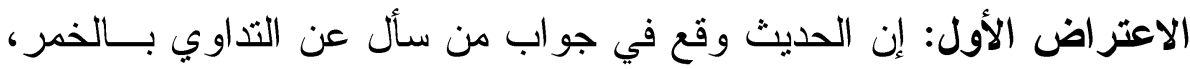
و لا يجوز إلحاق غير المسكر به من سائر النجاسات ؛ لأن شرب الأبن المسكر يجر

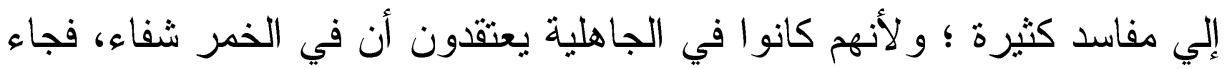
الشر ع بخلاف ذلك (633)

\section{أجيب عنه من وجهين: - أنزا:}

أ-أن دعوي الخصوصية بالخمر في الحديث لا دليل عليها، ومــن ثــــــا فــا تشمع (634).

ب-أن قصر التداوي بالمحرم في الحديث علي الخمر فقط، قصر للعام علـي السبب بدون موجب، و العبرة بعدوم اللفظ لا بخصوص السبب(

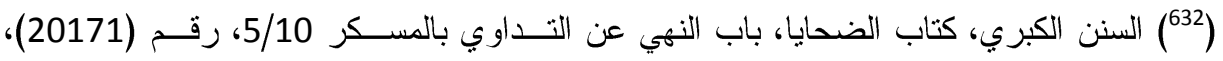

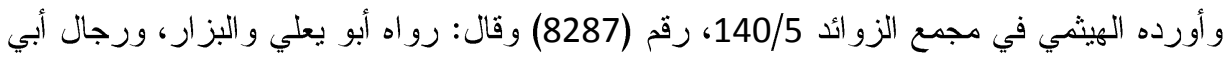

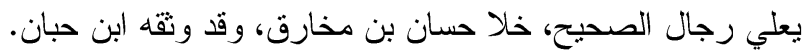

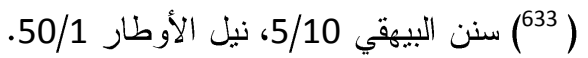

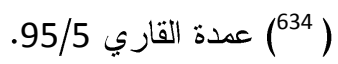

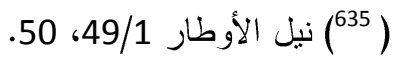




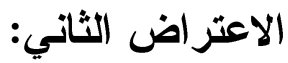

لا نسلم أن معني الحديث كما قلتم، بل معناه: أن ما فيه شفاؤكم منـــه حــرم

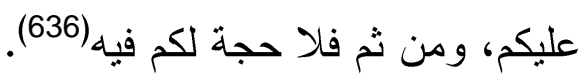
الاعتراض الثالث: أن هذا الحديث إن صح، فإنه يحمل علي التداوي بالمسكر

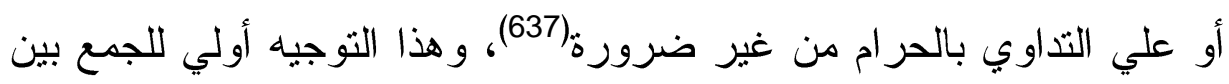

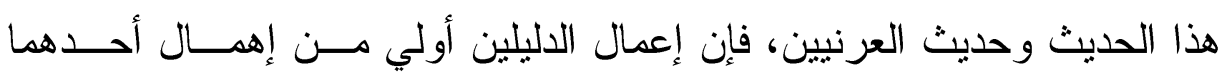
و إعمال الآخر (638).

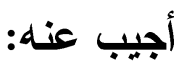

بأنه لا يخفي ما في هذا الجمع من التعسف، فإن الخصم يمنع اتصاف أبوال

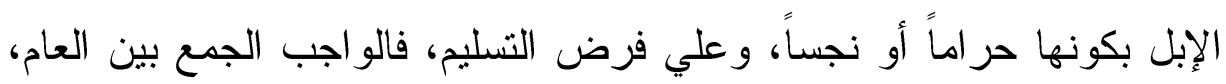

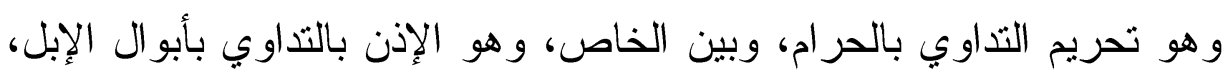

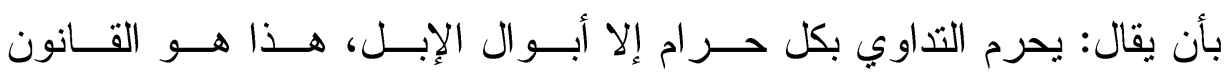
الأصولي (639).

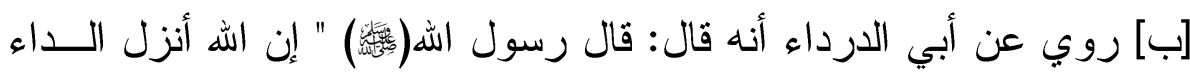
و الدو اء، وجعل لكل داء دو اءً، فتداوو ا، و لا تداوو البه بحر ام" (640).

170/15. الحاوي الكبير (636) (537) سنن البيهقي الكبرى 5/10، المجموع 50/9، الحاوي الكبير 170/15 نيل الأوطـــار 49/1،

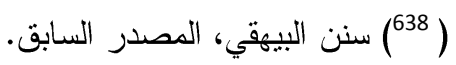

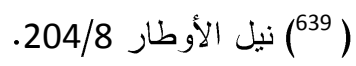

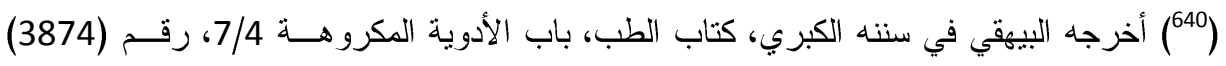

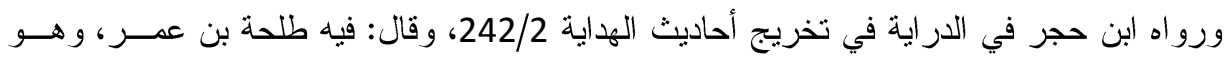


وجه الالاية: الحديث فيه أمر ونهي، فالأمر بالتداوي من الداء، و النهي إنمـــا

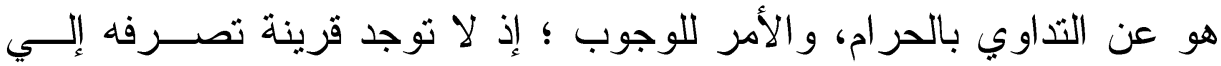
الندب و النهي يقتضي التحريم ؛ إذ لا توجد قرينة تصرفه إلي غيره، فدل ذلك علي عدم جواز التداوي بالمحرم أو النجس. وقد اعترض علي هذا الاستدلال باعتر اضين:

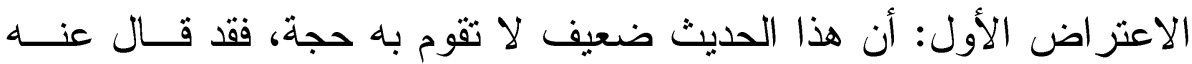

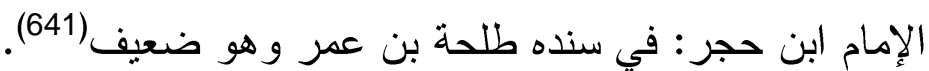

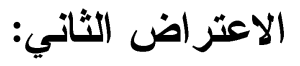

اعترض علي هذا الحديث بنفس الاعتر اض الثالث علـي حــديث أم ســلمة

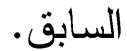

وأجيب عنه: بما أجيب عن الاعتر اض علي حديث أم سلمة.

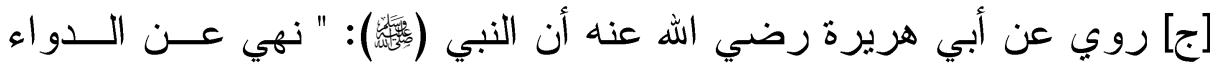
الخبيث "(642).

وجه الدلالة: الحديث يدل دلالة واضحة علي حرمة التداوي بالدواء الخبيث،

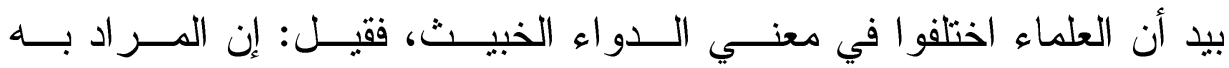

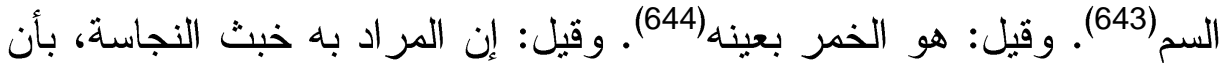

(641) الدراية في تخريج أحاديث الهواية، المصدر السابق.

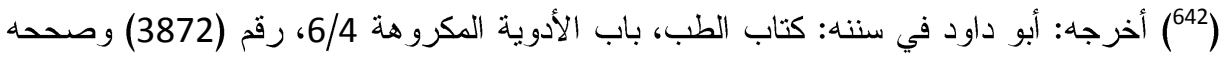

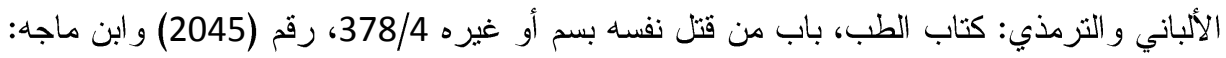

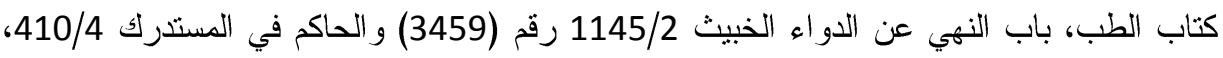

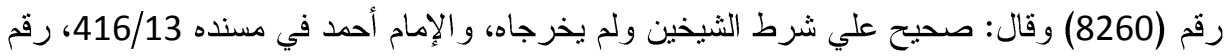

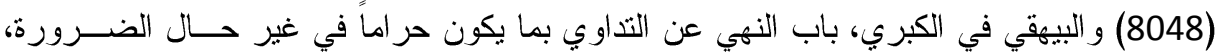

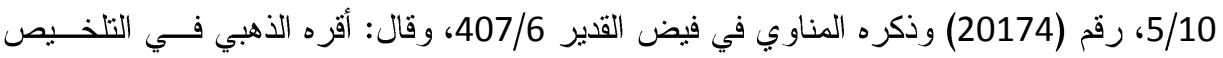
وقال في المهذب: إسناده صحيح.

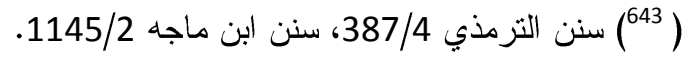




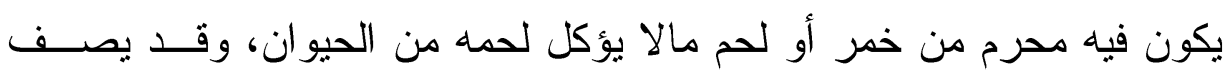

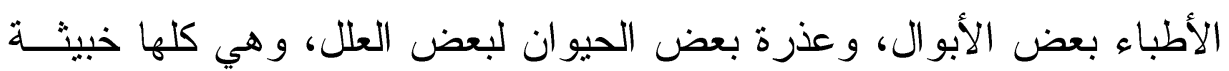

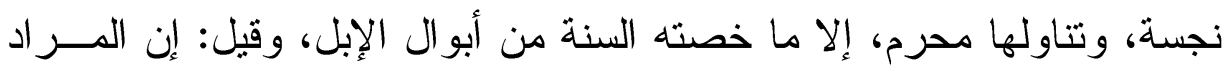

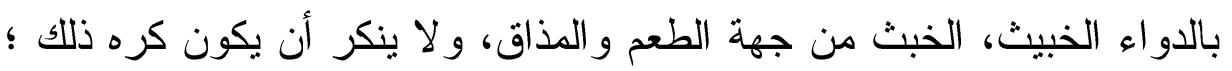

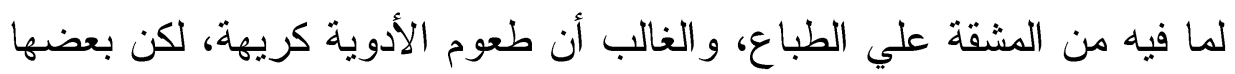

$$
\text { أيسر احتمالا و أقل كر اهية(645). }
$$

بنفس الاعتر اض الثالث علي حديث أم سلمة السابق. وأجيب عنه: بما أجيب علي الاعتر اض علي حديث أم سلمة.

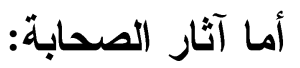

[أ] أخرج البخاري في صحيحه عن عبد الله بن مسعود رضي الله عنه أنــهـ

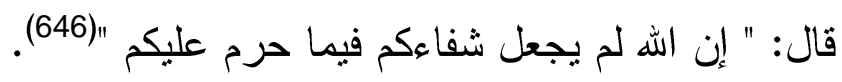

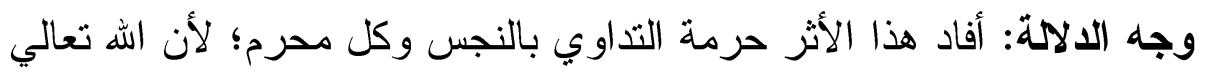

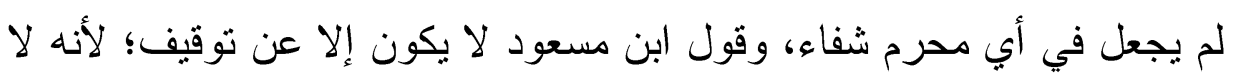
مجال للر أي فيه(647).

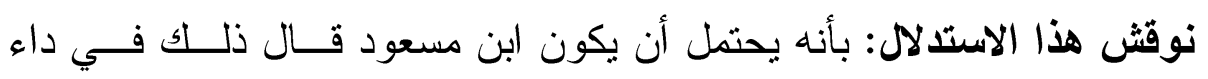

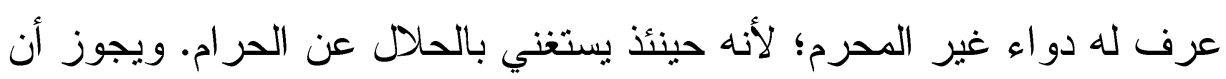

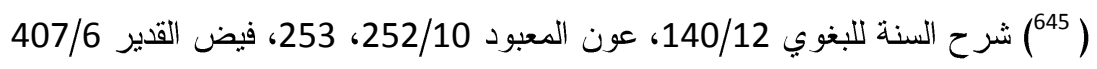

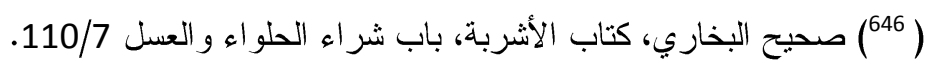

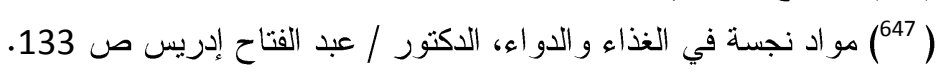




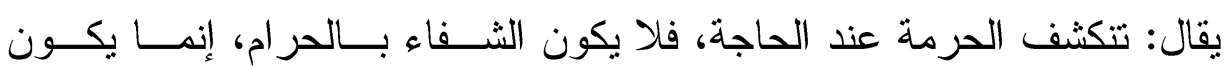
بالحلال (648).

[ب] أخرج البيهقي في سننه أن عبد ربه بن سعيد حدث أنه سمع نافعاً يقول: "

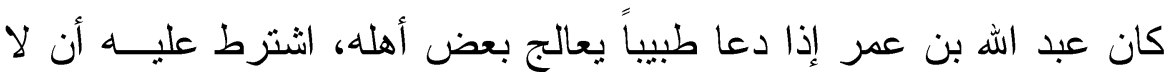
يداوي بشئ مما حرم الله عزوجل "(649).

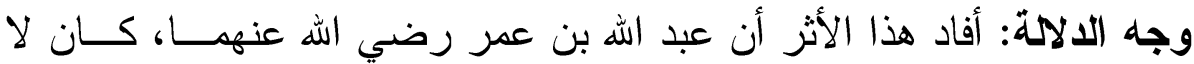

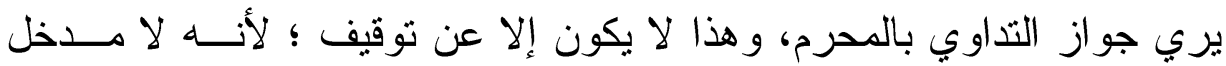
للر أي فيه(650). أما المعقول: فاستدلو ا به من وجوه:

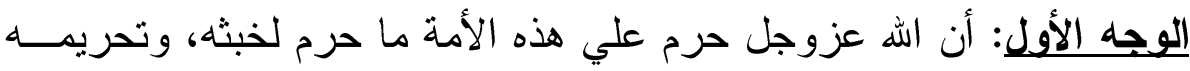
له حماية لهم، وصيانة عن تناوله، فلا يناسب أن بطلب به الثفاء من الأســقام

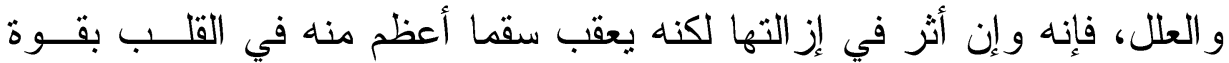

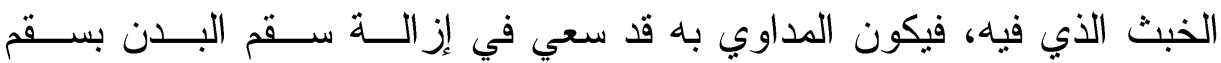
(651) القلب

الوحه الثاني: أن تحريم الثئ يقتضي تجنبه و البعد عنه بكل طريق، وفـي

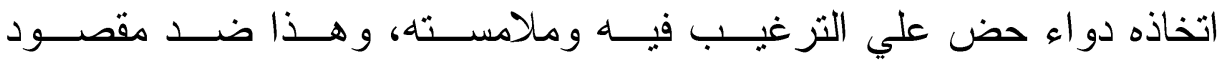

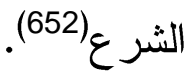

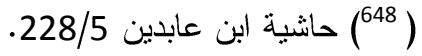

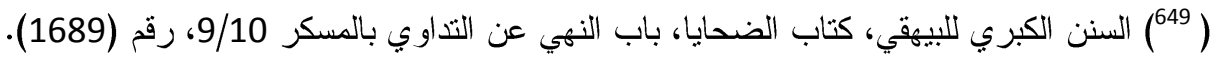

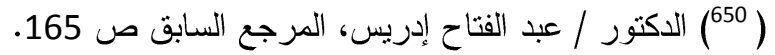

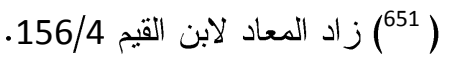

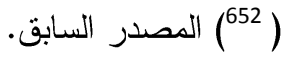

$$
\begin{aligned}
& \text { doi: } 10.12816 / 0004230
\end{aligned}
$$


الوحه الثالث: أن الدواء المحرم أو النجس يكسب نفس المتداوي بــه صــفة

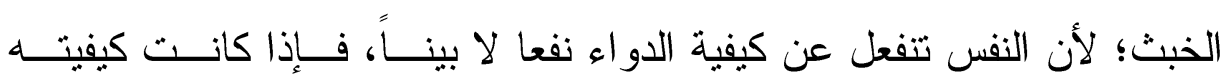

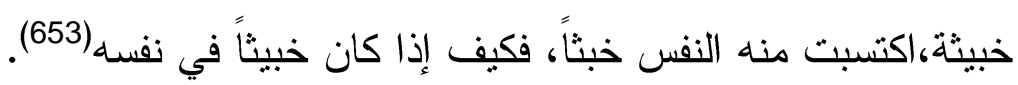

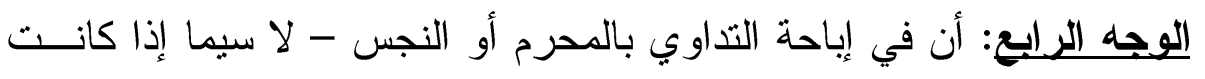

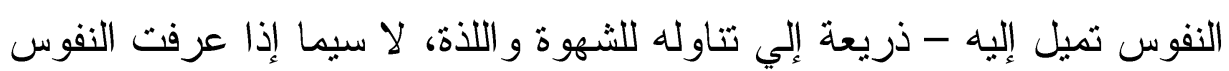

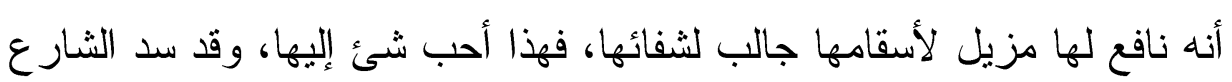

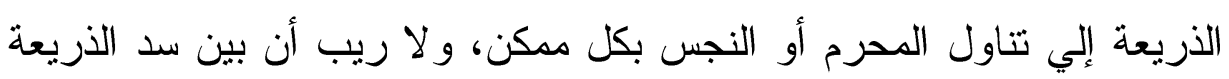

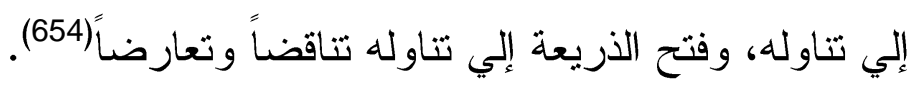

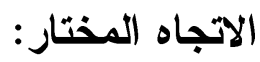

بعد النظر في الاتجاهات السابقة وأدلتهم، تبين لي أن الاتجاه الأول، وهو أنه

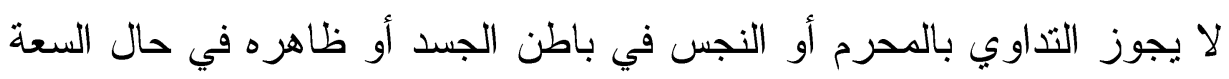

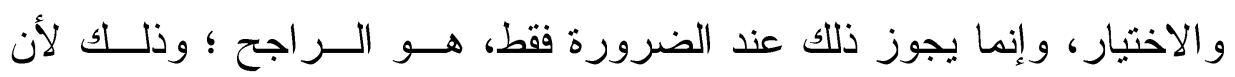
الضرورة تبيح المخطورة كأكل الميتة للمضطر . فئل

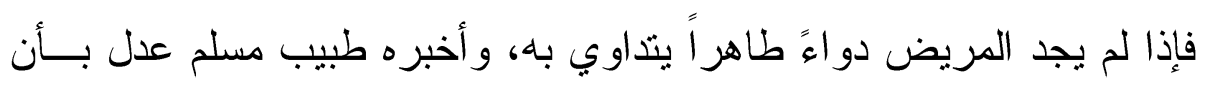

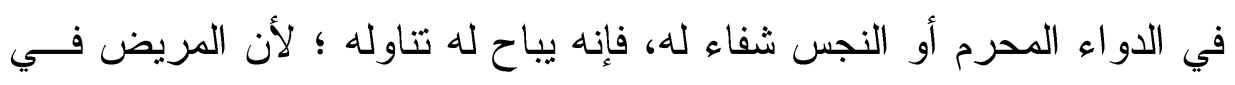

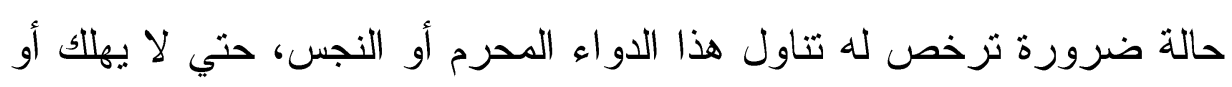
بصاب بضرر بالغ.

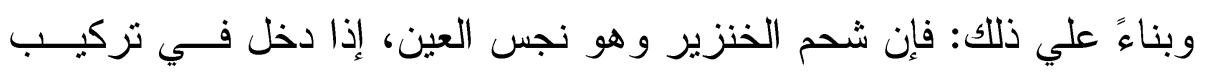

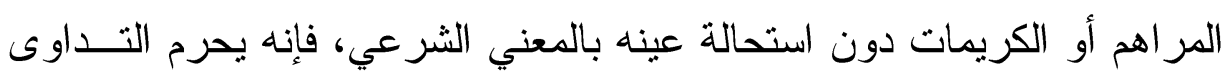

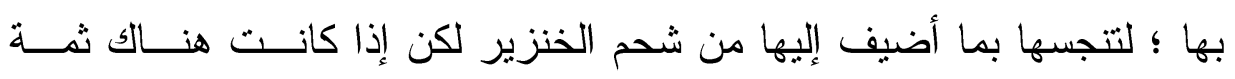


ضرورة تدعو إلي التداوي بهذه المنتجات، فلا حرج في التداوي والانتفاع بها شرعاً للضرورة. وقد جاء في توصيات الندوة الفقهية الطبية الثامنة للمنظمة الإسلامية للعلــوم الطبية المنعقدة بدولة الكويت في مايو 1995م: " أن المر اهم و الكريمات ومو اد اد التجميل التي يدخل في تركيبها شحم الخنزير، لا يجوز استعمالها إلا إذا تحققت

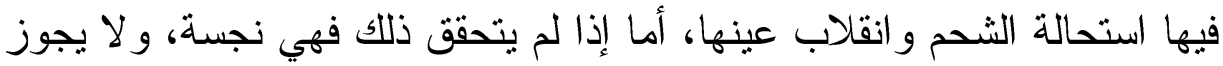
استعمالها شرعاً " أي: في حال السعة و الاختيار .

\section{المطلب الر ابع}

\section{موقف الفقه الإسلامي من الاتتفاع بالام المسفوح}

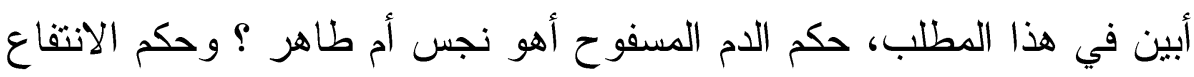
به، وذللك من خلال فرعين كالتالي:

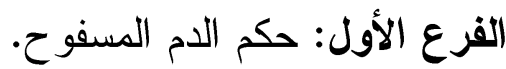
الفرع الثاني: حكم الانتفاع بالدم المسفوح ح.

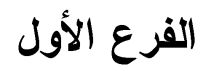

\section{حكم الام المسفوح}

المر اد بالدم المسفوح في هذا المقام: الدم الذي يجري أو يسيل من الحيــوان

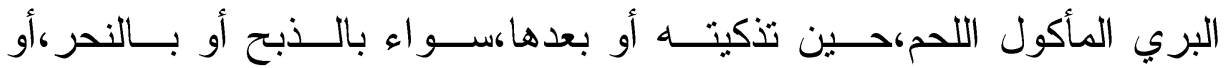

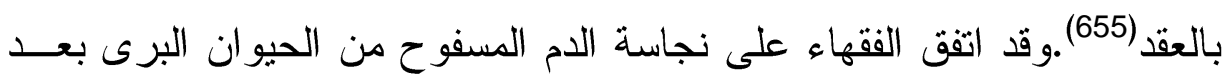
تذكيته(656) وقد استدلو العي ذلك بأدلة من الكتاب و الإجماع.

$$
\text { (655) حاثية الاسوقي و الثرح الكبير 52/1، مو اهب الجليل 135/1. }
$$

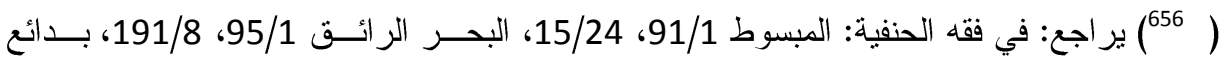

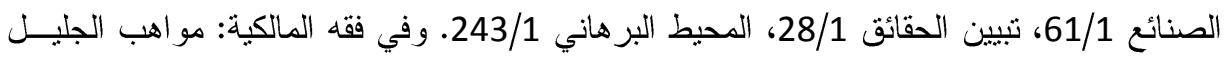

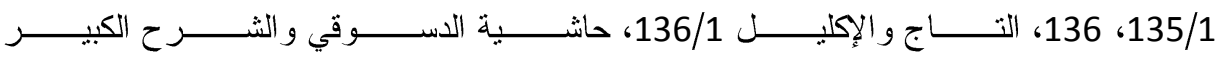

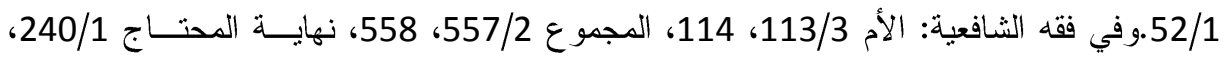
doi: $10.12816 / 0004230$ 


\section{أما الكتاب:}

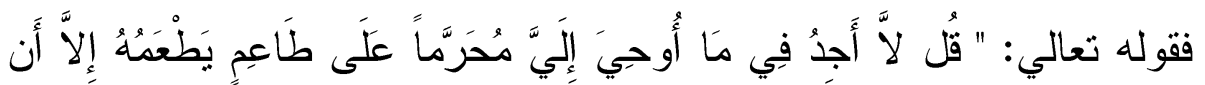

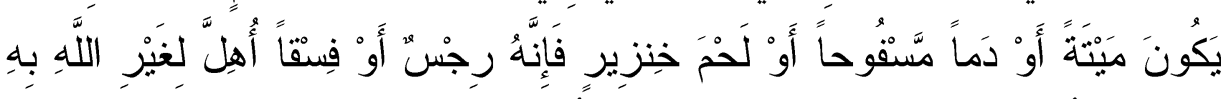

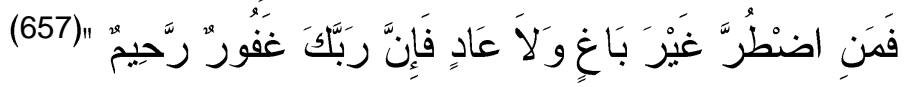

\section{وجه الدالةة:}

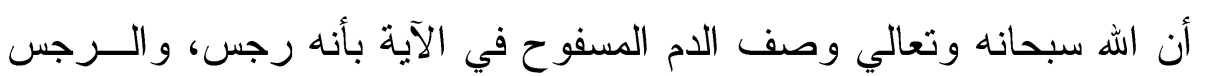

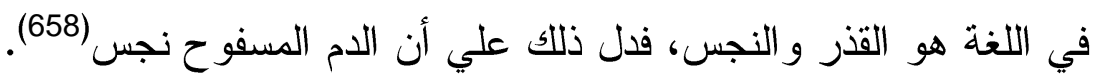

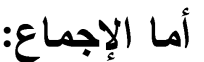

فقد حكي الإمام ابن رشد (الحفبد) إجماع العلماء علي نجاســة دم الحيــوان

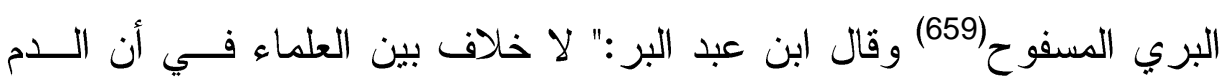

$$
\text { أمسفو ح رجس نجس" (660. }
$$

فاستدلوا به فقالو ا: إن الدم المسفوح نجس العين بنص القرآن الكريم، فأشـــبه

$$
\text { الميتة ولحم الخنزير (661). }
$$

مغني المحتاج 112/1. وفي فقه الحنابلة: الإنصاف 235/1، الكافي في فقه ابـن حنبـل 153/1، 153/1،

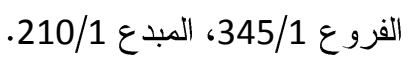

$$
\text { (145) (1457) سورة الأنعام، بعض الآند }
$$

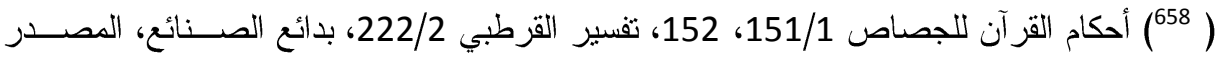

$$
\begin{aligned}
& \text { (601/1 (659) بداية المجتهد } \\
& \text { (606/1 (660) }
\end{aligned}
$$

153/1 (الكافي في فقه ابن حنبل (601) 


\section{الفرع الثاني \\ حكم الاتتفاع بالام المسفوح}

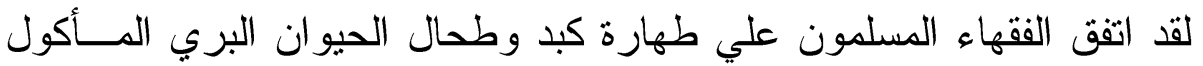

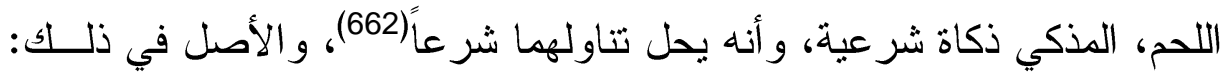

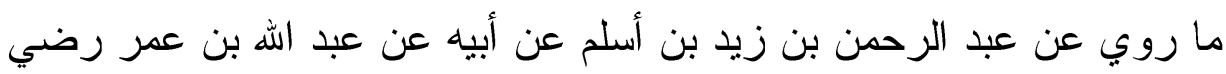

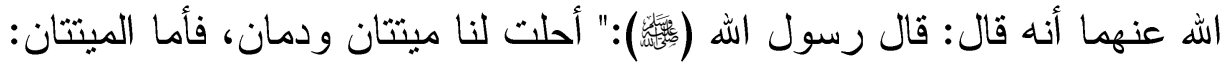
فالجر اد و الحيتان، و أما الدمان: فالكبد و الطحال "(663.

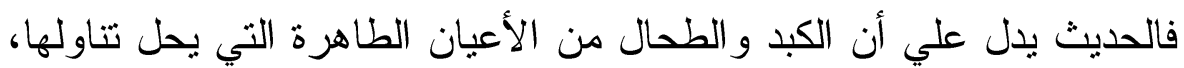

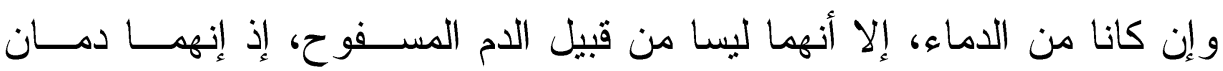
متجمدان، فهما طاهر ان، يحل تتاولهما شر عاً، يشهد بذلك العيان (664).

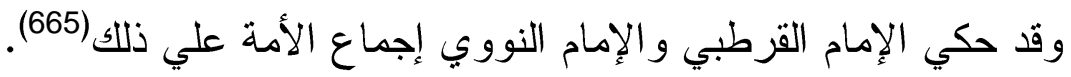

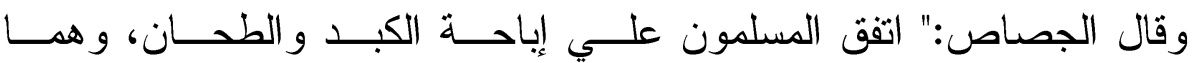
دمان"(666)وبمثل ذلك قال المرداوي الحنبلي (667).

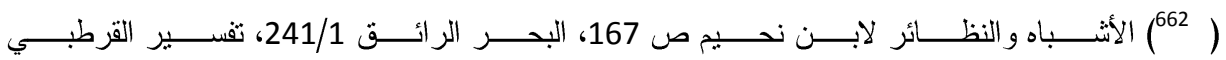

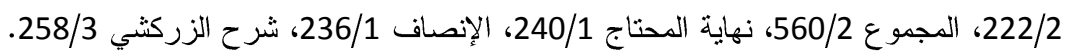

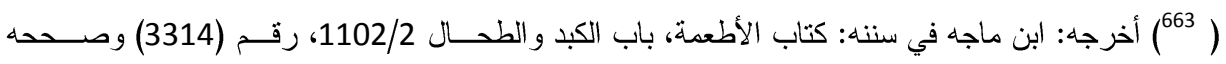

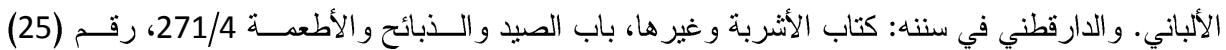

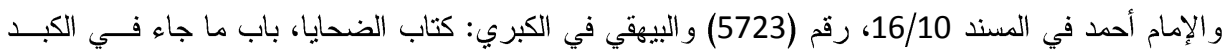

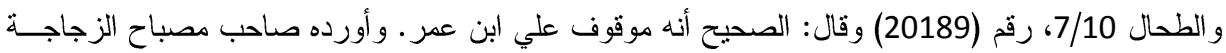

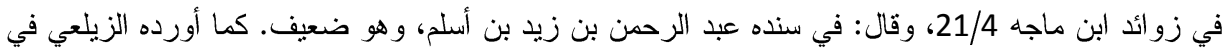

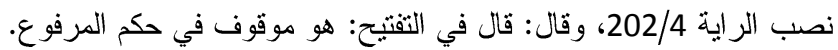

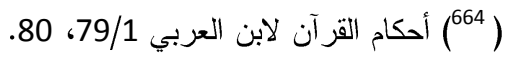
(665) (كتسير القرطبي، المجموع، الصصدرين السابقين.

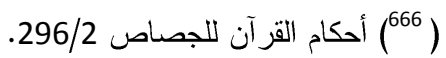

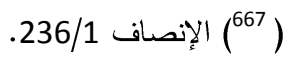


كما أنه لا خلاف بين الفقهاء، علي أن الدم المسفوح مــن الحيــوان البــري

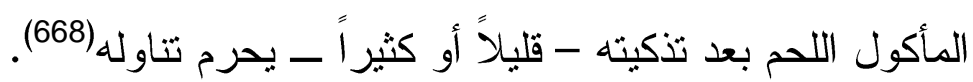

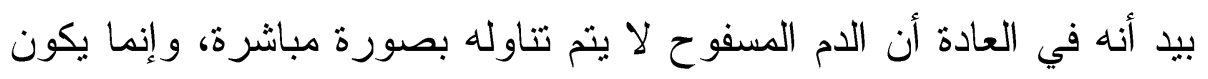

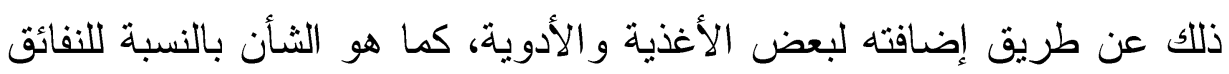

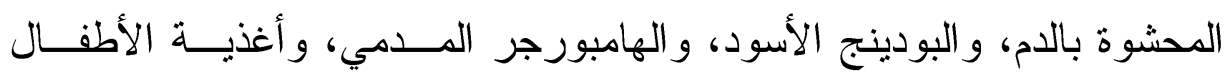
المحنوية علي الدم، وعجائن الدم، و الحساء بالدم ونحو ذللك (669).

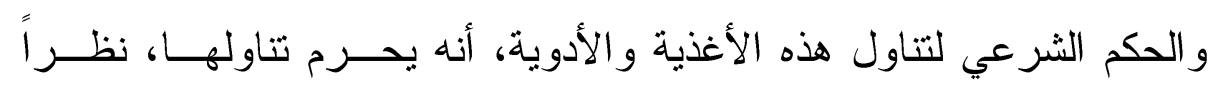

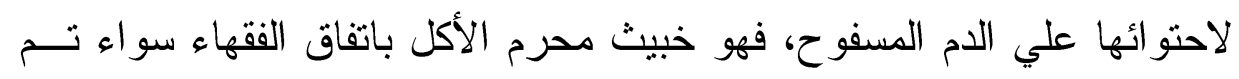

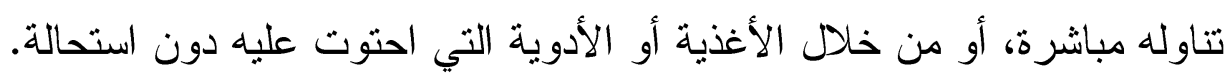

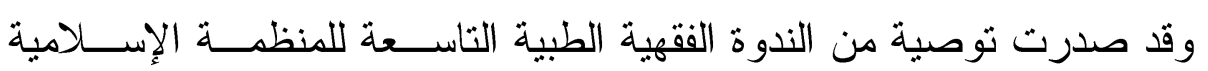
للعلوم الطبية المنعقدة بالدار البيضاء في يونيو 1997م، مندة مفادها أن:" المركبات

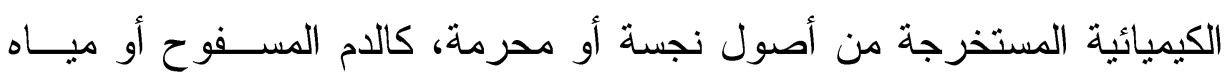

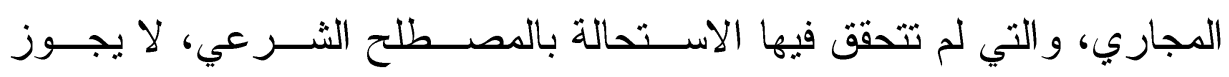

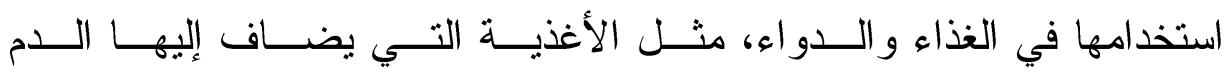

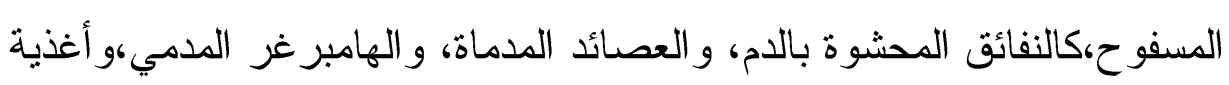
الأطفال المحتوية على الدم، وعجائن الدم، والحساء بالدم ونحوها، تعتبر طعاماً

(668) المبسوط 91/1، 15/24، البحر الرائق 95/1، 135/1، 191/8، بدائع الصنائع 136/1، 61/1، تبيين الحقائق

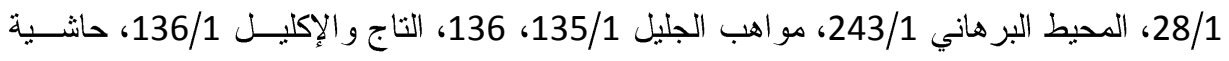

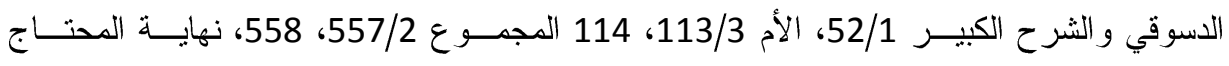

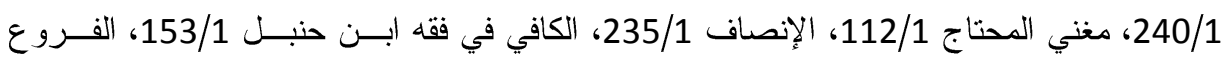
345/1، المبدع 210/1، 210/. (669) مشكلة استخدام المو اد المحرمة في المنتجات الغذائية و الدو ائية، بروفسور محمد عبد الســام

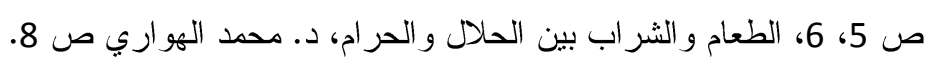




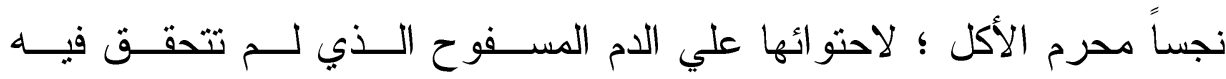

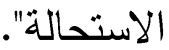

لكن قد لا يستخدم الدم المسفوح في صـــناعة الأغذيــة و الأدويــة بصـــورة

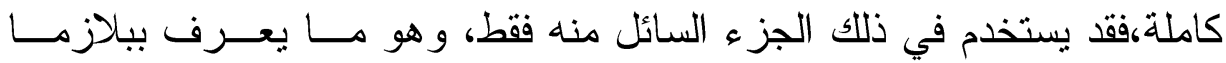

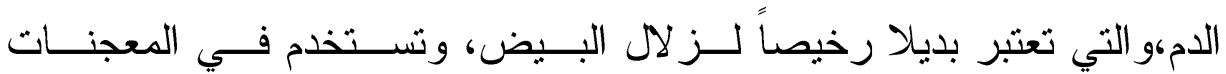

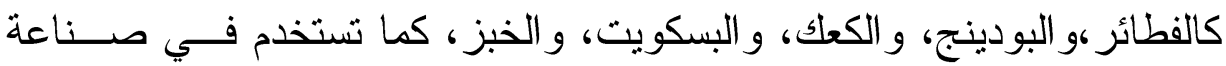
أدوية الأطفال و أغذيتهم، وصناعة منتجات الألبان. وقد يستخرج من بلازما الدم المسفوح ومن الغبرين الموجود في جلطات هذا

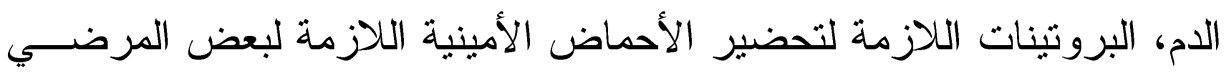

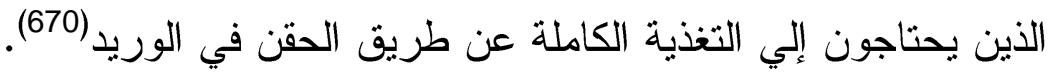
والحكم الثرعي لتناول هذه الأغذية والأدوية:

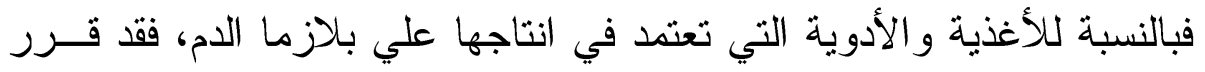

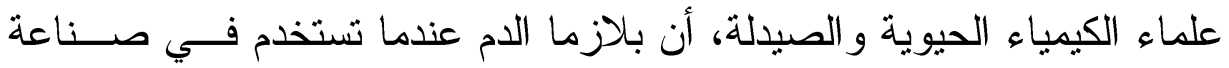

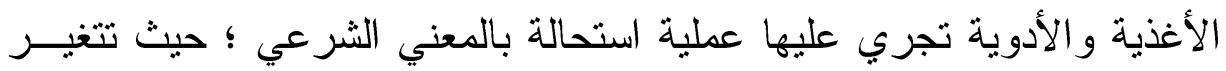

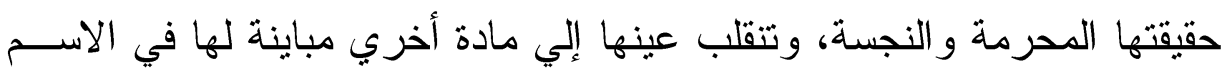
و الخصائص و الصفات(671).

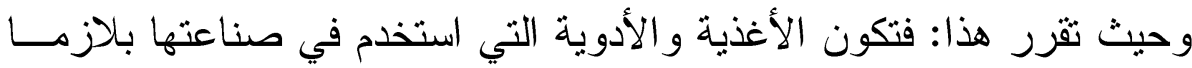
الدم المسفوح طاهرة حلال أكلها والانتفاع بها شرعاً. جاء في الروضة الندية شرح الدرر البهية: " الاستحالة مطهرة، و الأولي أن

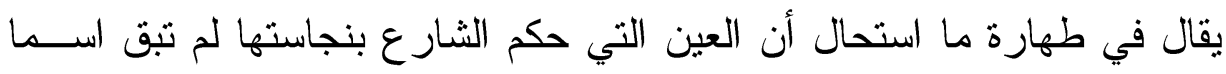

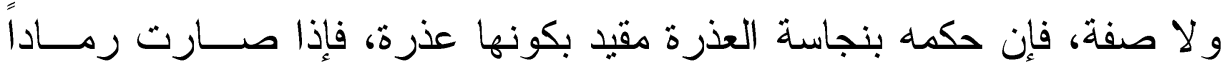

(670) المرجعين السابقين، المو اد المحرمة والنجسة في الغذاء و الدواء، د. نزيه حماد ص 87، 88.

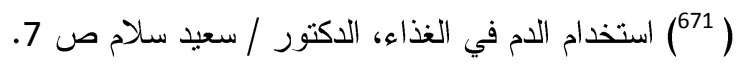




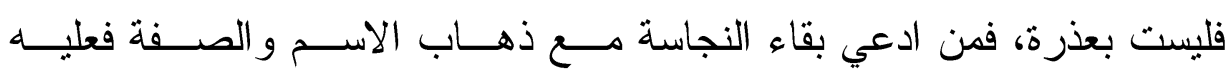
الدليل"(672).

وقد جاءت توصية من الندوة الفقهية الطبية التاسعة للمنظمة الإسلامية للعلوم الطبية المنعقدة بالدار البيضاء في يونيو 1997م، مفادها " أما بلازما الـدم -

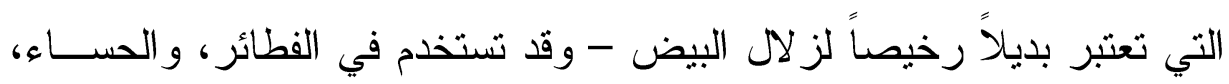
و العصائد (البودينج) و الخبز، ومشتقات الألبان، و أدوية الأطفال و أغذيتهم،و التي

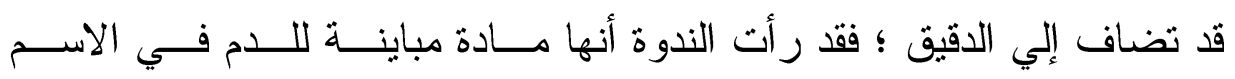
و الخصائص و الصفات، فليس لها حكم الدم، وإن رأي بعض الحاضرين خلاف الف ذللك". "و لا يختلف الحكم بالنسبة للبروتينات المستخرجة من بالزما الدم المسـفوح

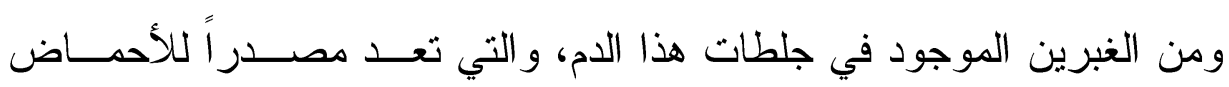
الأمينية اللازمة لتغذية بعض المرضي عن طريق الحقن فـي الوريــد، فهـــا

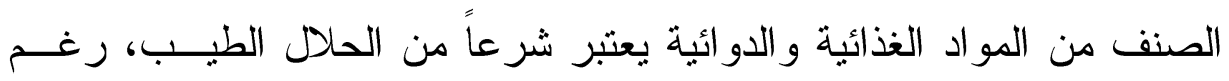

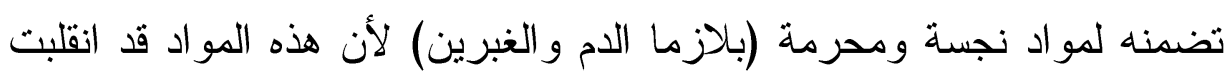

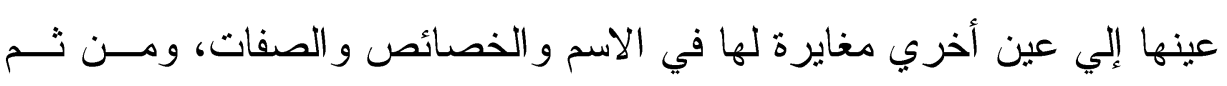
تكون الأغذية و الأدوية التي دخلت هذه المواد في صناعتها طــاهرة، يجــوز

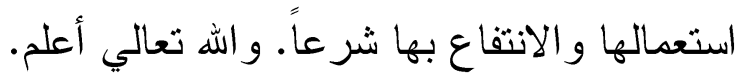




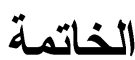

وبعد الوقوف على جزئيات هذا البحـــث المتـــاثرة، وجمعهــا فــى كتــاب

و احد،أعود فألخص أهم النتائج التى توصلت إليها بإيجاز فى النقاط التالية:

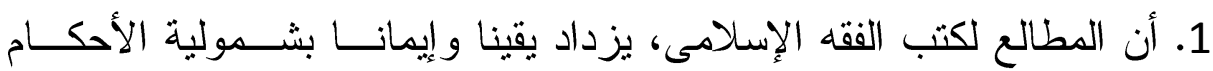
الشرعية، ووفائها بجيمع متطلبات البشرية، وقدرتها التامة على تتظيم حياة الناس تتظيما دقيقا، عادلاً متقنا، وفى ذلك رد على على المدعين قصور الأحكام الشرعية و عجز ها عن مسايرة ركب الحضارة ومستجدات العصر .

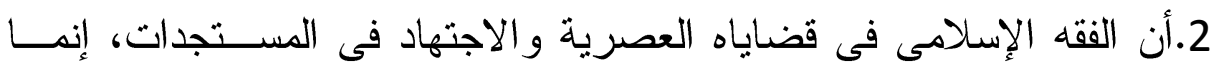

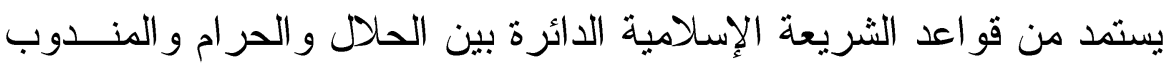
و المباح، وعليه فالفقه الإسلامى هو الجانب التطبيقى للأدلة التفيلية فـى الإسلى الشريعة الإسلامية، مما يؤكد توثيق العلاقة بين الفقه و الثريعة الإسلامية.

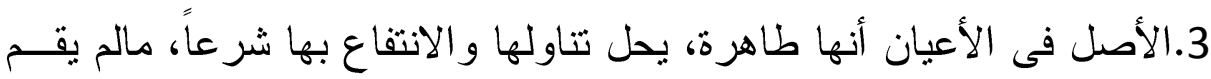
دليل شرعى معتبر على نجاستها.

4.للطهارة أهية كبرى فى الإسلام، وهى فى الفقه الإسلامى نوعان: طهارة

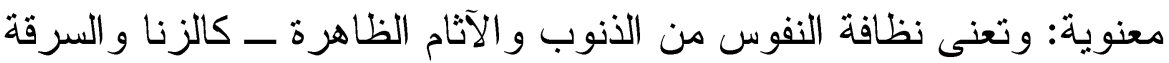

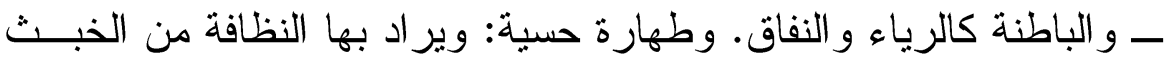
و الحدث، و هى الطهارة الفقهية التى تر اد للصلاة. 5.الطهارة التحسينية من مقاصد الثريعة الإسلامية، وتعنى: النظافة الشخصية الدائمة للإنسان من حيث بدنه وثوبه ونعله ومكانه و البيئة المحيطة به ونحو ذللك. ويقصد بهاخلو الإنسان وبيئته من الأدناس و الأقذار.

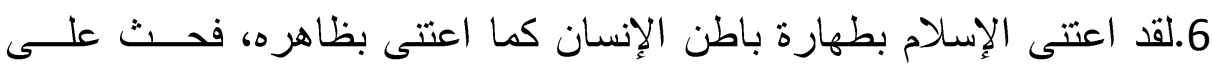

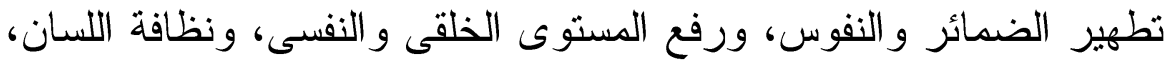
و استبعاد قالة السوء من المجتمع المسلم. 
7.الاستحالة: هى تحول العين النجسة إلى عين أخرى، بمكن معها الانتفاع بها

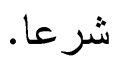

8.التكييف الفقهى للاستحالة، يعنى أن العين النجسة أو المحرمسـة التتــاول إذا

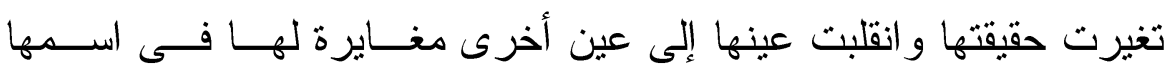
وخصائصها وصفاتها، فإنها تصير طاهرة طيبة يحل تناولها و الانتفاع بها

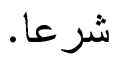

9.بناء على الاتجاه الراجح فى الفقه الإسلاهى، فإن المياه النجسة أو المتتجسة

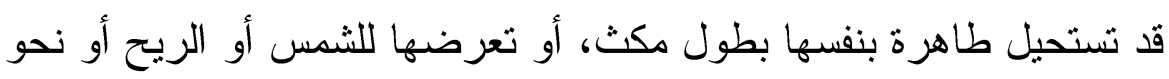
ذللك، كما تستحيل طاهرة بعدة طرق تقليدية كالمكاثرة و النزح و الإضــافة.

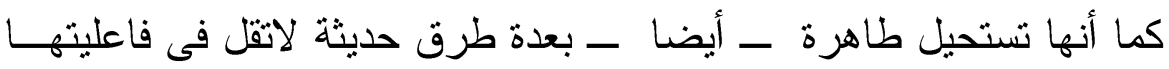
و إمكان التطهير بها عن نلاك الطرق التقليدية التى ذكرها الفقهاء.

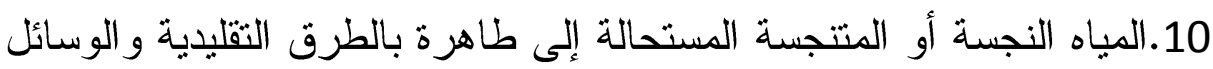

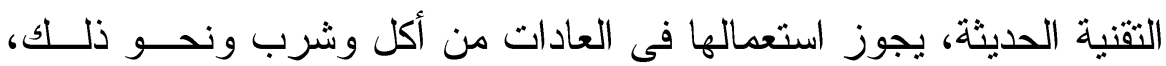
وفى العبادات كالوضوء و الغسل، وفى مجالات الزر اعة و الصناعة، وأشهر

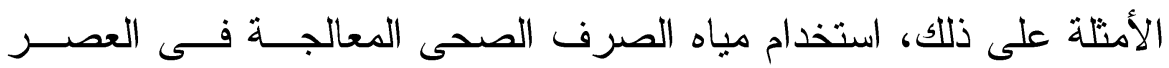
الحديث فى كافة الدجالات. 11.يجوز - طبقا لأرجح الأقوال ـ سقى وتسميد وتغذية النباتسات و الثــار بالنجاسات، ويجوز تبعاً لذلك تناولها و الانتفاع بها شرعا، مالم يظهر أثــر النجاسة فيها، ومالم يثبت ضرر ها على الصحة.

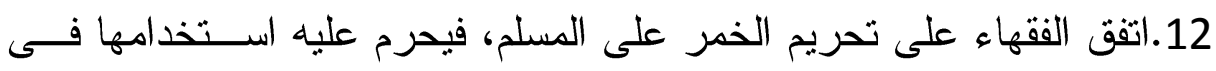

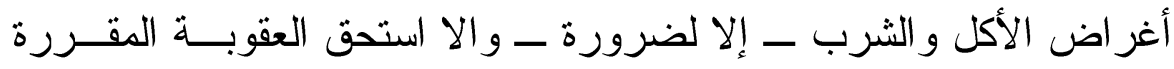

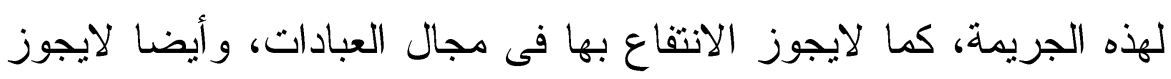


الاتتفاع بها فى الأغراض الأخرى كسقى الدواب و التذاوى بها عند جمهور الفقهاء.

13.اتفق الفقهاء على أن الخمر إذا استحالت خلا بنفسها من غير فعل فاعـل،

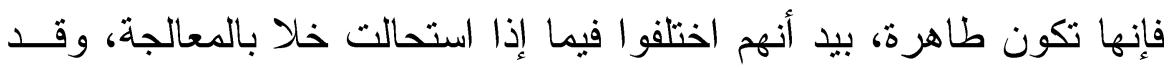

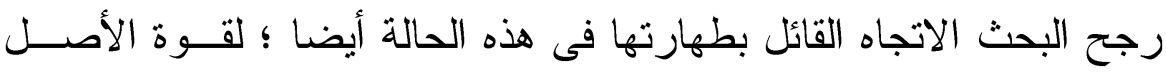
الذى بنى عليه هذا الاتجاه، وهو أن العلة فى نجاسة الخمر هى الإسكار،وهد

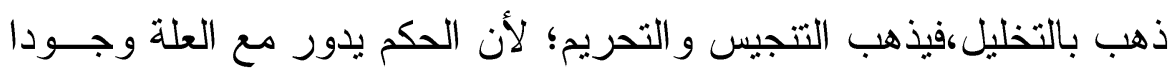
و عدما.

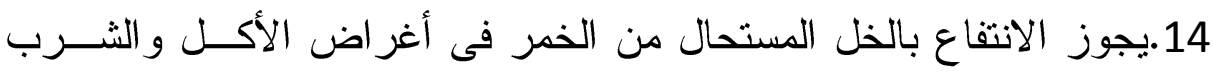

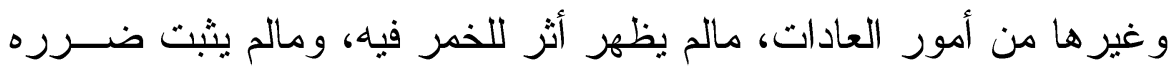

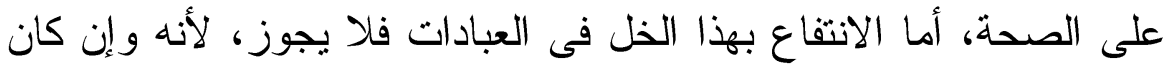

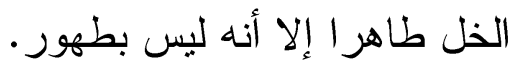

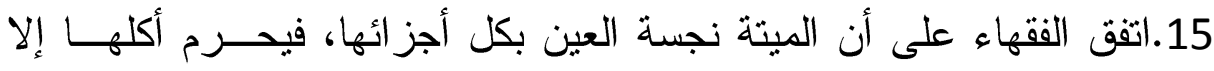
ل لضرورة.

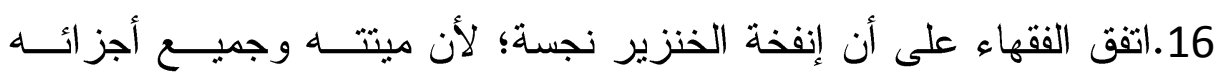

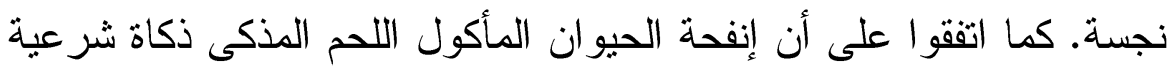

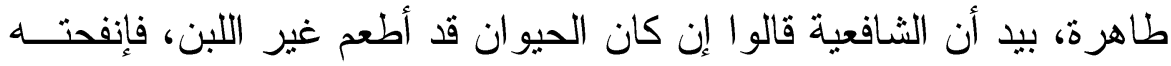
نجسة. أما إنفحة ميتة غير الخنزير و المذكى ذكاة غير شرعية، فهى نجسة النها

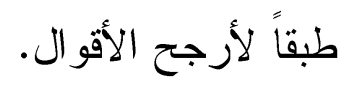

17.اتفق الفقهاء على أن الجبن المصنوع بإنفحة الحيوان المأكول اللحم المذكى

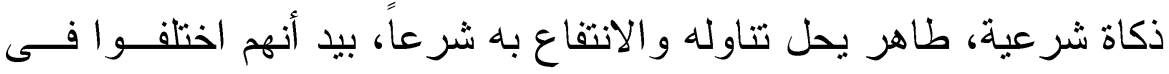

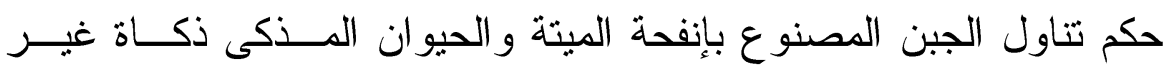

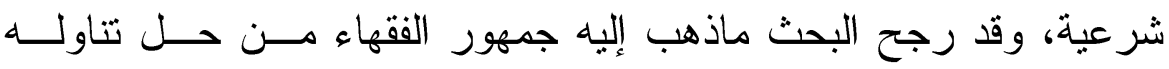

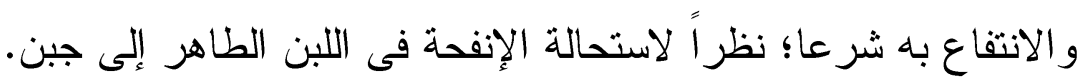


18.إذا دبخ جلد الميتة بما فى ذلك جلد الكلب والخنزير، انقلب طاهراً بالدباغ،

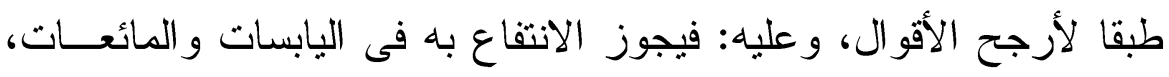

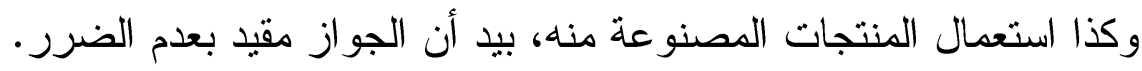

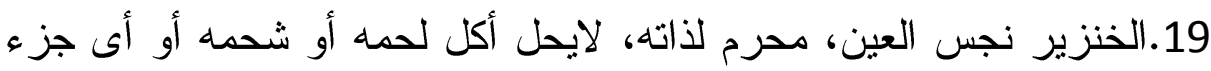

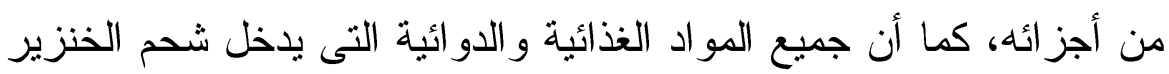

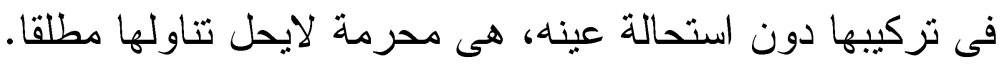

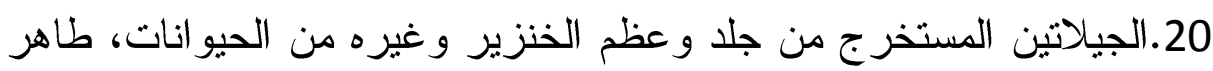

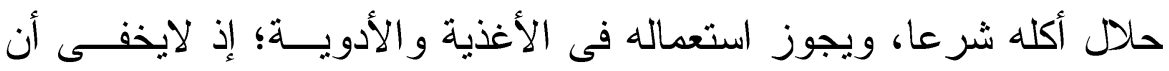
الجيلاتين تجرى عليه عملية استحالة كيميائية تؤدى إلى استحالته بـــالمعنى ولئه

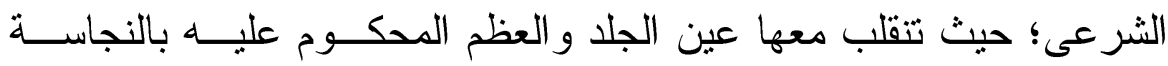
و الحرمة إلى مادة أخرى مباينة لأصله فى الاسم و الخصائص و الصفات.

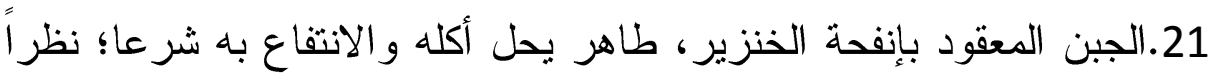
لتحول الأصل (الإنفحة) النجس المحرم إلى عين أخرى (الجبن) لايتتاولها

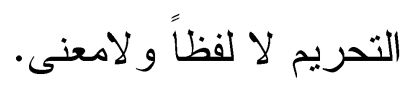

22.الأغذية و الأدوية التى يدخل في تركيبها مادتا الكوليسـترول و الليسـتين المشتقتات من أنسجة الخنزير وغيره من محرم الأكل، تعتبر طاهرة طيبة لأنية مباحة شر عا للاستحالة. 23.الإنسولين المشتق من غدة بنكريـــاس الخنزيـــر، يعتبـــر مــن الحـــلال

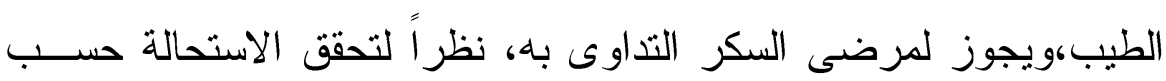
تكييفها الفقهى عند استخلاص هذه المادة.

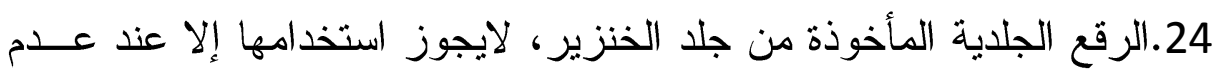
وجود البديل الجائز شرعاً وعند الضرورة، شريطة أن تكون مؤقتة. 
25.شعر الخنزير- طبقا لأرجح الأقو ال ـ طاهر مطلقاً، وبناء عليــه: فإنـــه يجوز الانتفاع به وبجميع المنتجات التى استخدم فيها شرعاً. 26.26الصابون ومعجون تتظيف الأسنان الناتج من استحالة شحم الخنزير أو

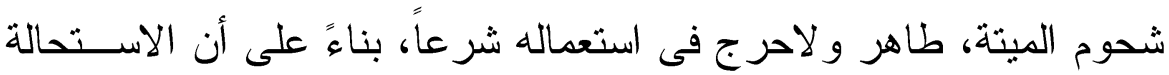
تحيل النجس أو المتنجس طاهراً، و المحرم مباحاً شرعا.

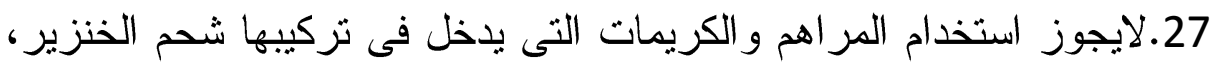

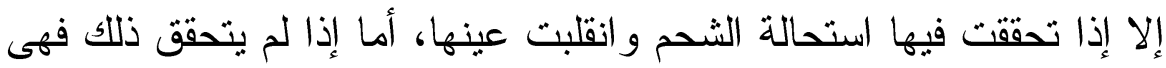
نجسة - طبقا لأرجح الأقوال ـ فلا يجوز استخدامها إلا عند الضرورة. 28.الدم المسفوح من الحيوان البرى المأكول اللحم بعد تذكيته نجـس باتة التــاق

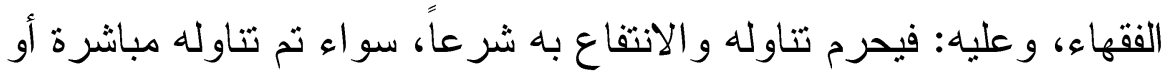
عن طريق إضافته إلى بعض الأغذية و الأدوية دون استحالة، كما هو الثأن

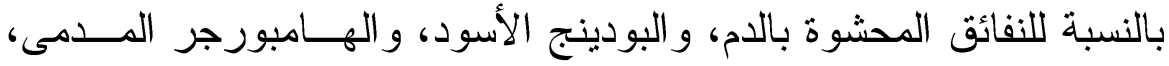

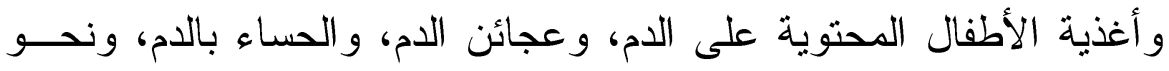
ذلك.

29.بلازما الدم - التى تعتبر بديلاً رخيصاً لصفار البيض - و التى تســتخدم

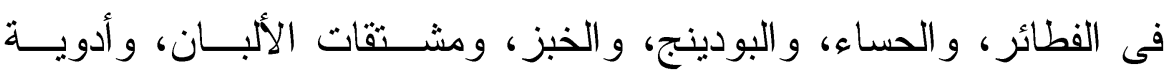
الأطفال و أغذيتهر، و التى قد تضاف إلى الدقيق، تعتبر طيبة حلال التناول ؛ نظر اً لاستحالتها فى الطاهر المباح.

30.نظر اً لتحقق الاستحالة فى البروتينات المستخرجة من بلازما الدام المباح المسفوح ومن الغبرين الموجود فى جلطات هذا الدم، فإنها تعتبر طيبة طاهرة شرعاً،

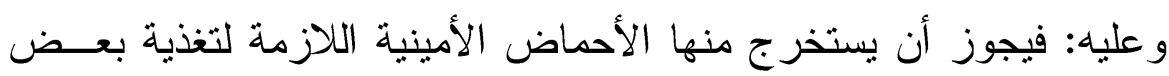

$$
\text { و اله تعالى أعلم، و ولاحرج فى ذلك شرعاً. }
$$


وبعد: فإن هذا مايسر الله عز وجل لى كتابته فى هــذا الموضــوع، وهـــا

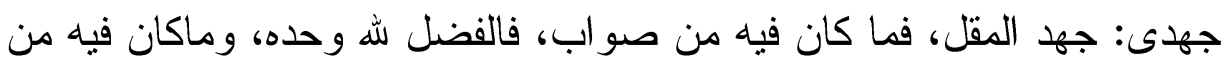

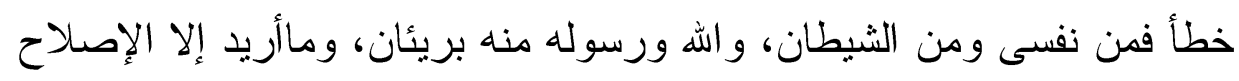
ماستطعت، وماتوفيقى إلا باله، عليه نوكلت و إليه أنيب.

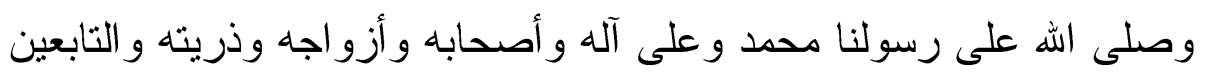
لهم باحسان وسلم تسليماً كثير أ إلى يوم الدين. والحمد الله رب العالمين

دكتور

عبده السيد الشريف 
استحالة النجس إلى طاهر للانتفاع به فى الفقه الإسلاهى د.عبده السيد أحمد الثريف

\section{فهرس بأهم المصادر والمراجع(673)}

أولا: القرآن الكريم : تنزيل من رب العالمين .

\section{ثانيا: كتب التفسير وأحكام القرآن :}

1 ـ أحكام القرآن ، لأبى بكر أحمد بن على الرازى (المعروف بالجصاص) المتوفى سنة (370) هـ ، تحقيق : محمد قحاوى،طبعة دار إحياء

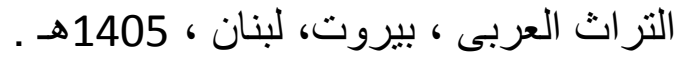

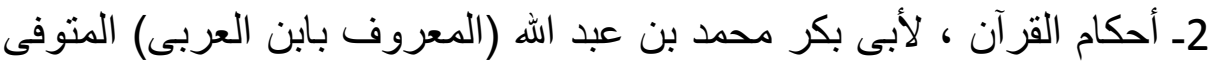

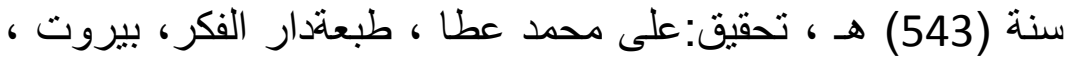

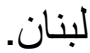

3ـ التحرير و التتوير ، لفضيلة الثيخ محمد الطاهر بن عاثور، دار النشر : دار

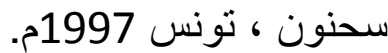

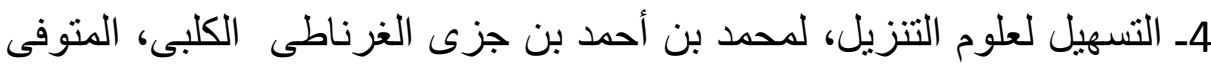

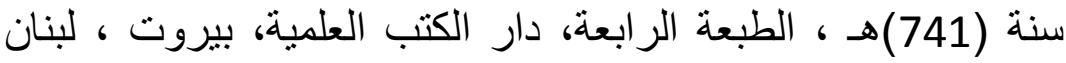

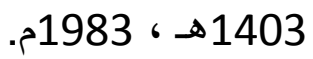

5- تفسير ابن كثير، للإمام إسماعيل بن عمر بن كثير الدمشقى، المتوفى سنة (774) هـ ، تحقيق : سامى سلامة ، نشر دار طيبة، الطبعة الثنانية

$$
\text { 1420هـ - 1999م. هـ ، }
$$

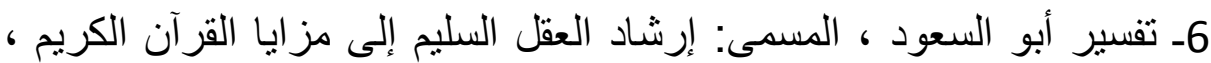

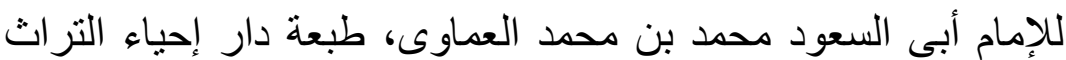

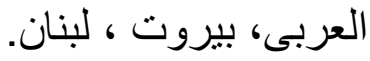

(673) رتبت المراجع حسب الترتيب الهجائي ، مع عدم الاعتداد بأداة التعريف . 


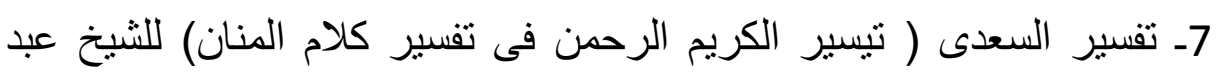

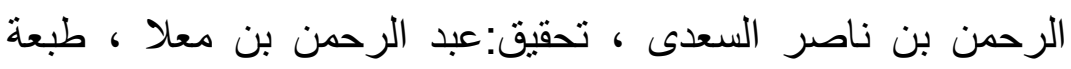

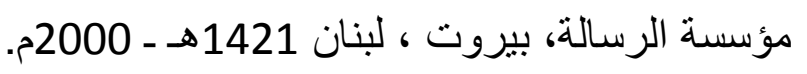

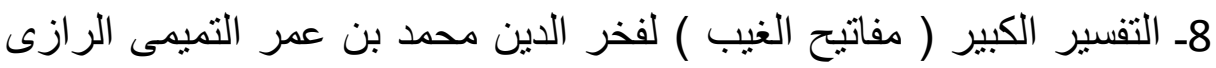

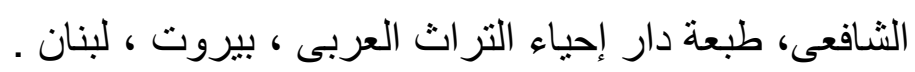

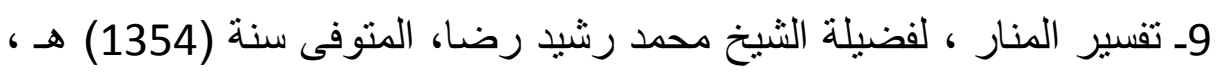

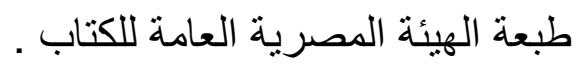

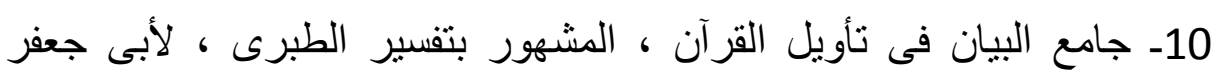

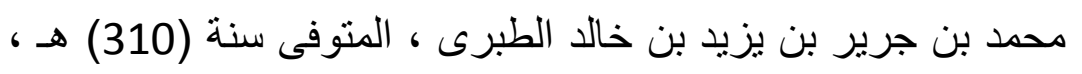

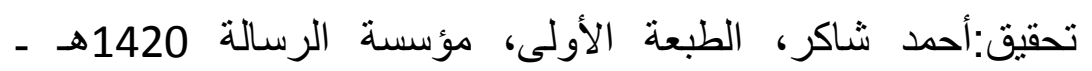
2000م.

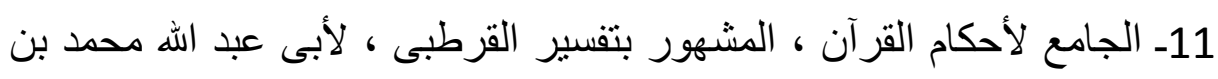

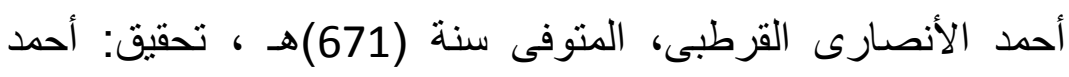

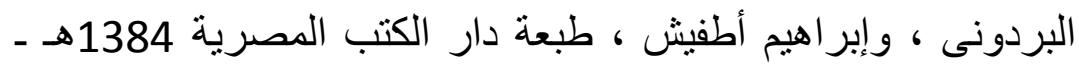
1964م.

12- روح المعانى فى تفسير القرآن العظيم و السبع المثانى، لأبى الفضل محمود

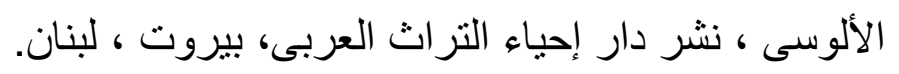

13 ـ الفتح القدير الجامع بين فنى الرواية والدراية ، المعروف بتفسير الثوكانى

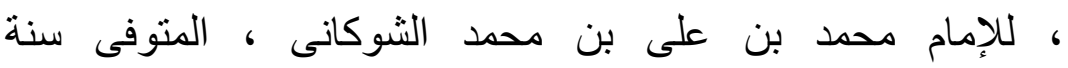

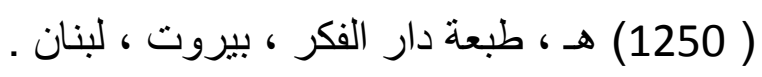

14 - فى ظلال القرآن ، لفضيلة الإمام الثهيد سيد قطب ، الطبعة السابعة عشر دار

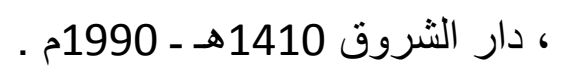

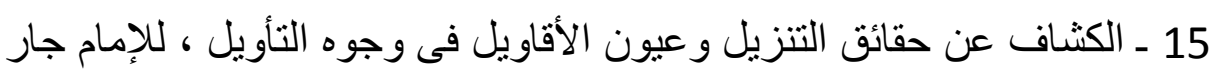

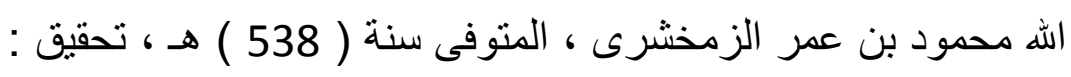
393 
عبد الرزاق المهدى ، طبعة دار إحياء التراث العربى ، بيروت ،

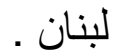

ثالثا: كتب الحديث وعلومه: - مان

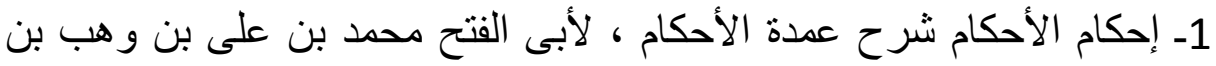

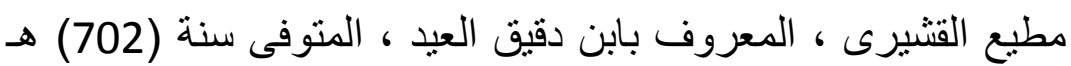

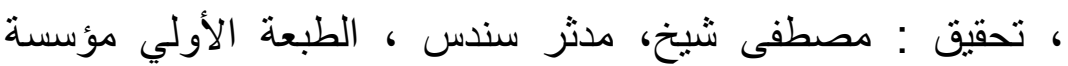

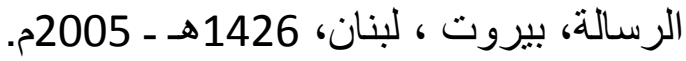

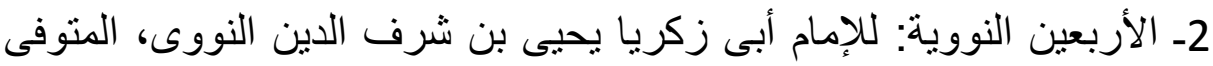

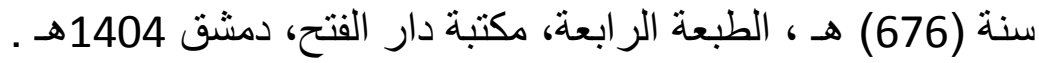
3- إرشاد السارى لثرح صحيح البخارى، لأحمد بن محمد بن أبى بكر بن عبد المبا

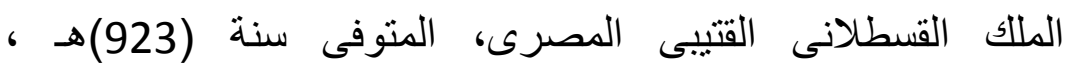
المطبعة|لكبرى الأميرية بمصر، الطبعة السابعة 1323هـ. 4- إرواء الغليل فى تخريج أحاديث منار السبيل، للشيخ محمد ناصر الدين

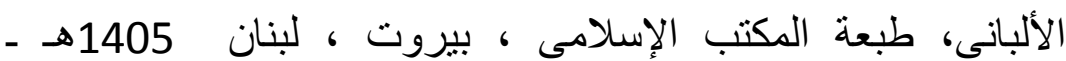

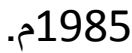

5- البدر المنير فى تخريج الأحاديث والآثار الواقعة فى الثرح الكبير، لأبى

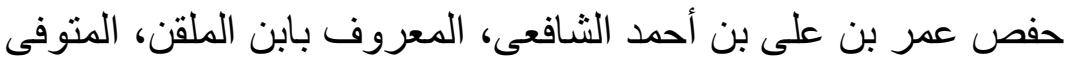

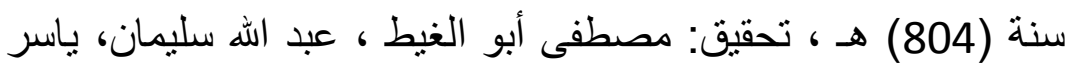

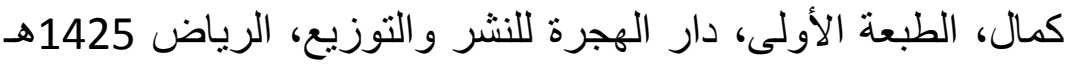
2004 -

6- بلوغ المرام من أدلة الأحكام ، للحافظ أحمد بن على بن حجر العسقلانى، المتوفى سنة (852) هـ ، بدون.

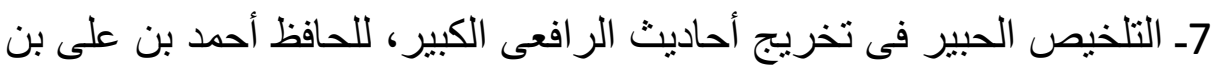

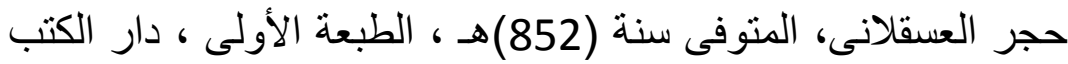

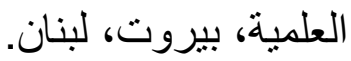




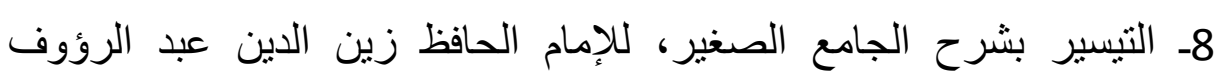

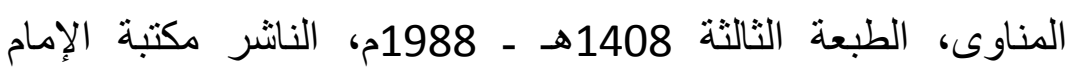
النشافعى ، بيروت ، لبنان.

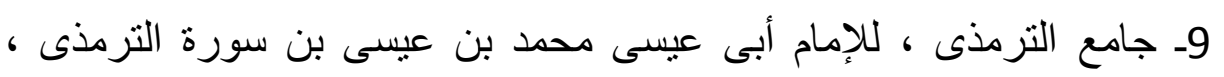

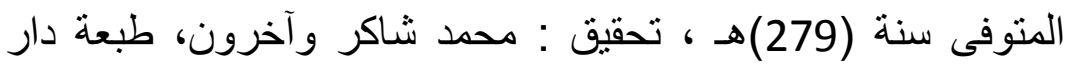

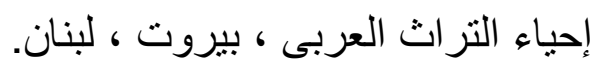

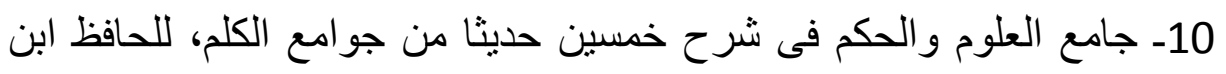

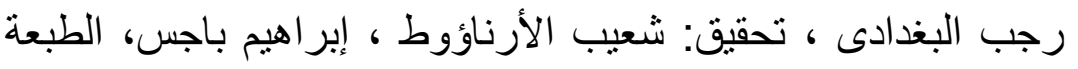

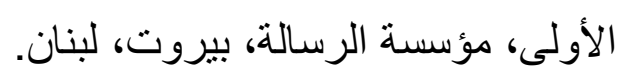

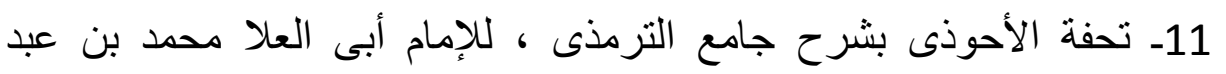

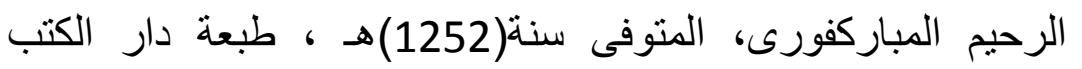

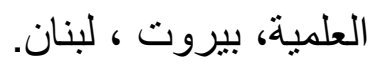

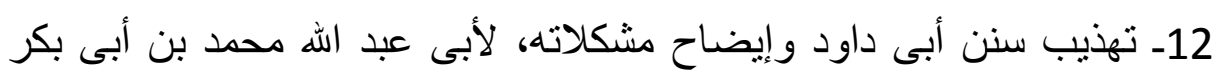

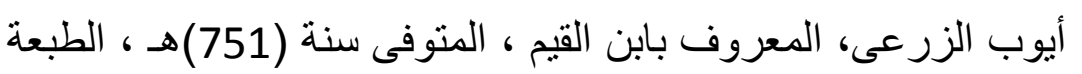

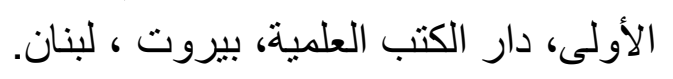

13 ـ الدراية فى تخريج أحاديث الهداية، للحافظ ابن حجر العسقلانى، تحقيق:

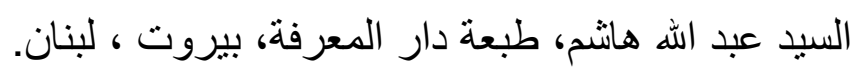

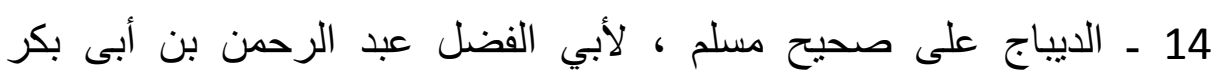

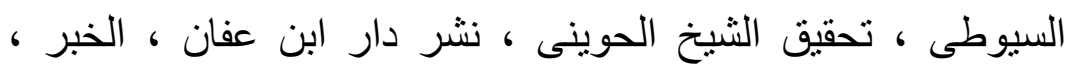
السعودية 1416 هـ - 1996 م .

15 ـ ذخيرة الحفاظ ، للإمام محمد بن طاهر المقدسى ، المتوفى سنة (507) هـ

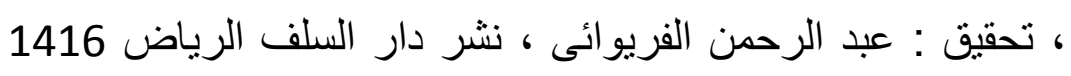

هـ - 1996 م ـ لهيف 
16- رياض الصالحين ، للإمام يحيى بن شرف النووى، المنوفى سنة (676)هـ ، تحقيق : الدكتور ماهر الفحل، بدون.

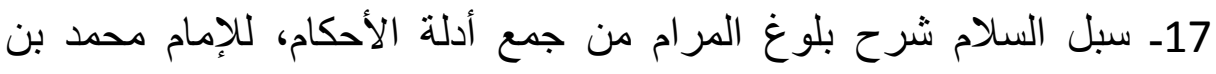

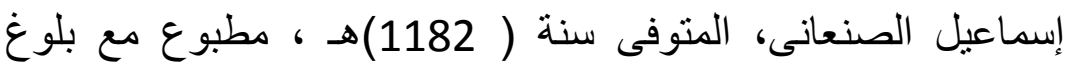

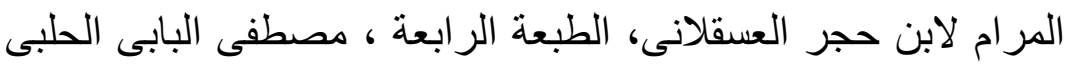

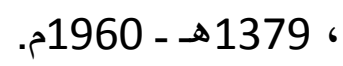

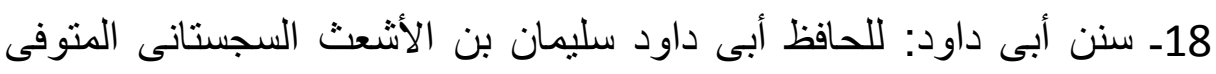

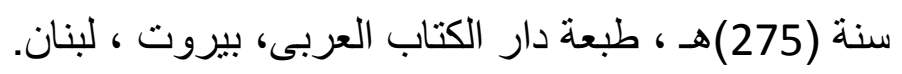

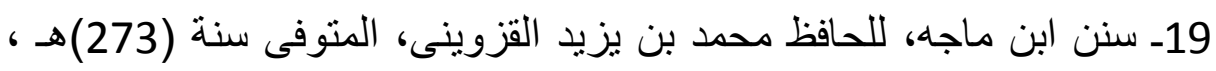

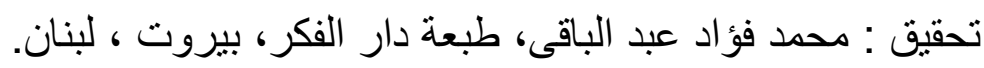

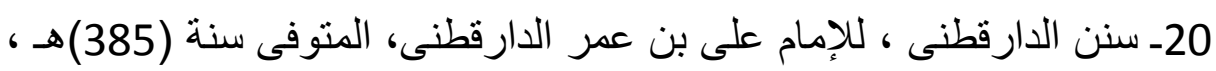

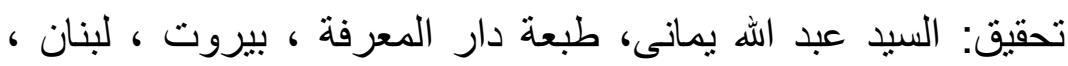
1386هـ - 1966م.

21- سنن الدارمى، للإمام الحافظ عبد الله بن عبد الرحمن بن الفضل بن بهرام

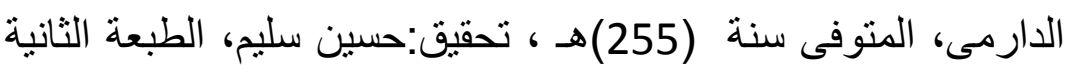

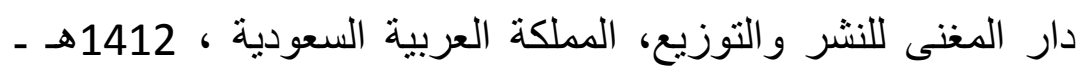
2000 2000

22- السنن الكبرى، للحافظ أبى بكر أحمد بن الحسين البيهقى،المتوفى سنة

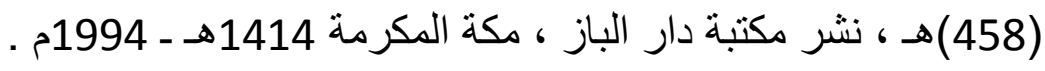

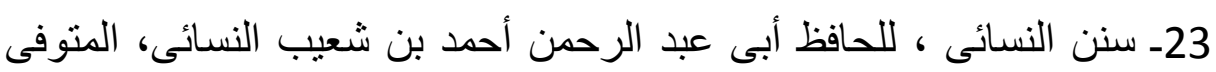

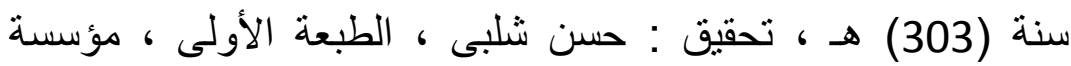

$$
\text { الرسالة 1421 14هـ - 2001م. }
$$

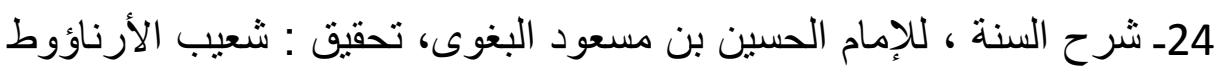

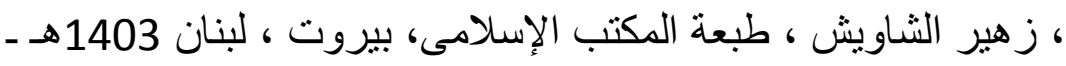


25- شرح صحيح البخارى، لأبى الحسن على بن خلف بن عبد الملك بن بطال

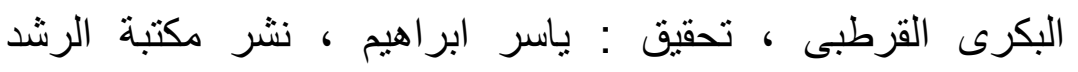

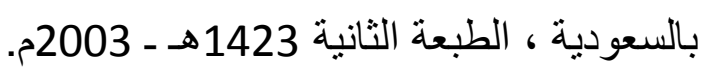

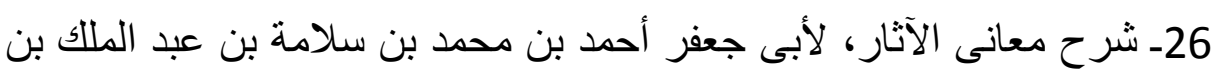

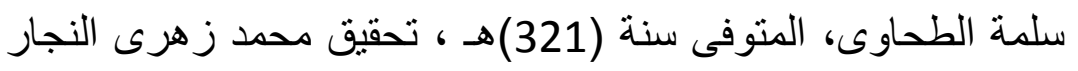

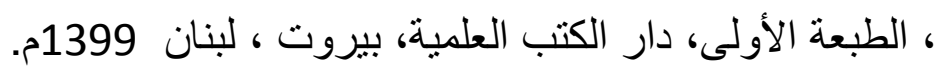

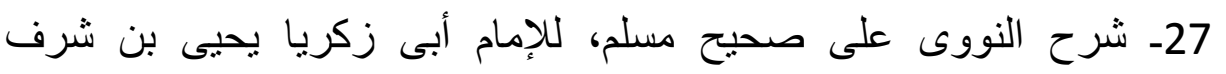

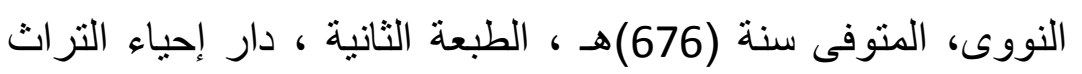

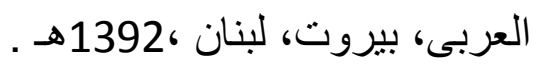

28- شعب الإيمان ، للبيهقى، تحقيق : محمد زغلول ، الطبعة الأولى، دار الكتب العلمية ، بيروت 1410 14هـ.

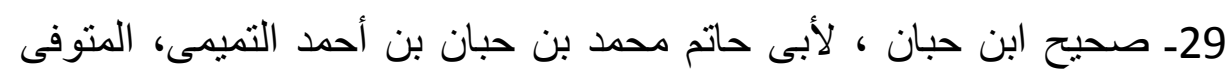

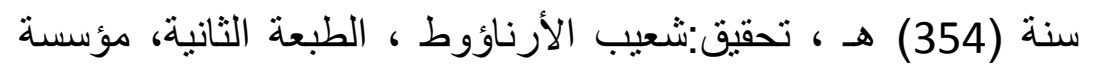

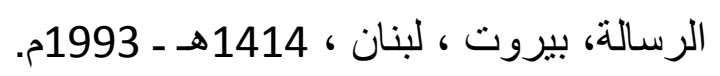

30ـ صحيح البخارى ، للإمام الحافظ محمد بن إسماعيل البخارى، المتوفى سنة

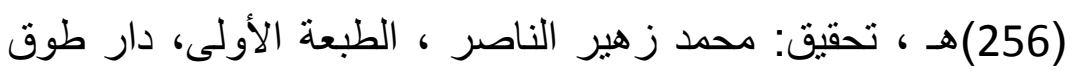
النجاة ، 1422هـ .

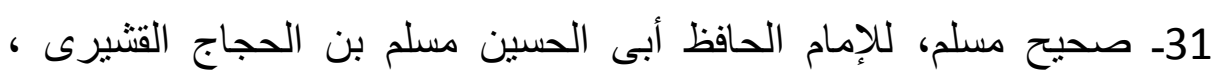

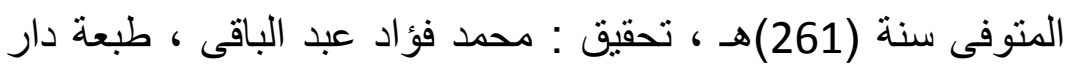
إحياء التراث العربى ، بيروت (261) ، لبنان.

32- عارضة الإحوذى شرح سنن الترمذى ، لابن العربى ، مطبعة الصاوى ، إهـ ،

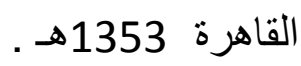

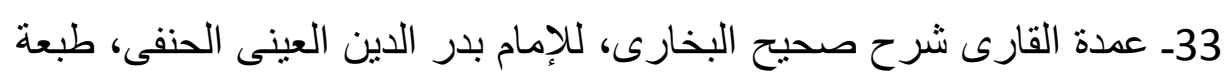
دار الكتب العلمية ، بيروت ، لبناح لبنان. 
34- عون المعبود شرح سنن أبى داود ، للإمام محمد شمس الحق العظيم أبادى،

الطبعة الثانية، دار الكتب العلمية، بيروت ، لبنان 1415هـ.

35- فتح البارى بشرح صحيح البخارى، للحافظ أحمد بن على بن حجر

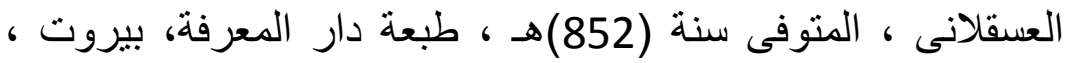

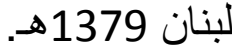

36- فيض القدير شرح الجامع الصغير، للثيخ عبد الرؤوف المناوى ، الطبعة الأولى ، دار الكتب العلمية ، بيروت ، لبنان 1415هـ - 1995م.

37- كنز العمال فى سنن الأقوال والأفعال، لعلاء الدين على بن حسام الدين المتقى الهندى، المتوفى سنة (975)هـ ، تحقيق : بكرى حياتى، صفوة السقا، نشر مؤسسة الرسالة، الطبعة الخامسة 1401هـ ،

1981

38ـ اللؤلؤ و المرجان فيما اتفق عليه الثيخان ( البخارى وسلم ) وضعه: محمد فؤاد عبد الباقى، طبعة دار إحياء الكتب العربية ، عيسى البابى الحلبى البه

$$
\text { وشركاه. }
$$

39- مجمع الزوائد ومنبع الفوائد ، للإمام على بن أبى بكر الهيثمى، المتوفى سنة (807)هـ ، طبعة دار الفكر ، بيروت لبنان 1412هـ.

40ـ درقاة المفاتيح شرح مشكاة المصابيح، للشيخ على بن سلطان محمد القارى المتوفى (1014)هـ ، تحقيق : محمد غيثانى ، الطبعة الأولى، دار الكتب العلمية، بيروت ، لبنان 1422هـ ـ 2000م .

41- در اسيل أبى داود ، تحقيق : شعيب الأرناؤوط ، الطبعة الأولى ، مؤسسة

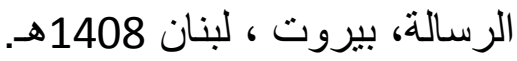

42ـ المستدرك على الصحيحين ، لأبى عبد الله محمد بن عبد الله ، النيسابورى ، المعروف بالحاكم، المتوفى سنة (405)هـ ، تحقيق: مصطفى عبد

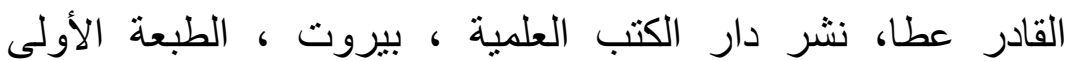

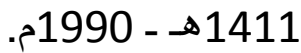


43- مسند الإمام أحمد ، لإمام المحدثين أبى عبد الله أحمد بن محمد بن حنبل

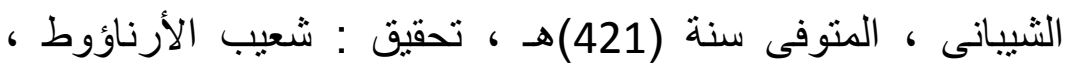

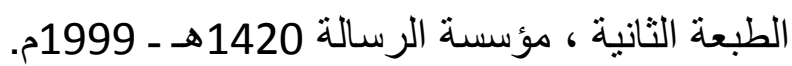

44- مصباح الزجاجة فى زوائد ابن ماجه، لأحمد بن أبى بكر بن إسماعيل

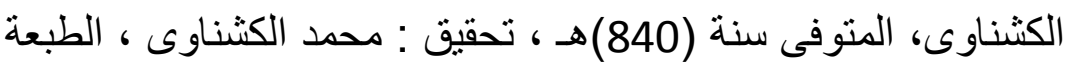

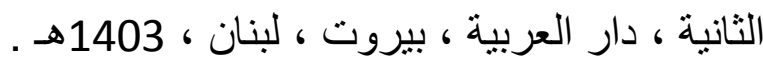

45- معالم السنن (للإمام أبى سليمان حمد بن محمد الخطابى ، المتوفى سنة

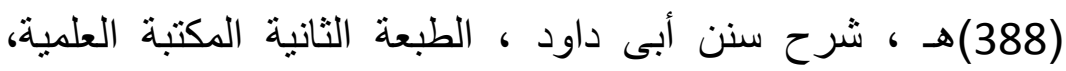

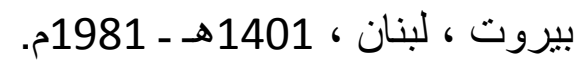

46ـ المعجم الأوسط، لأبى القاسم سليمان بن أحمد بن أيوب الطبرانى ، تحقيق :

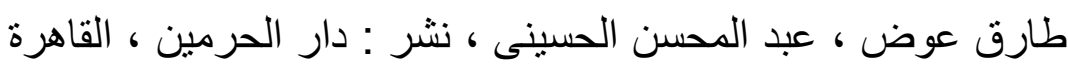
1415هـ .

47- المعجم الكبير ، للطبرانى ، تحقيق : محمد عبد المجيد ، الناثر: مكتبة

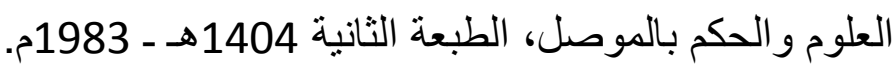

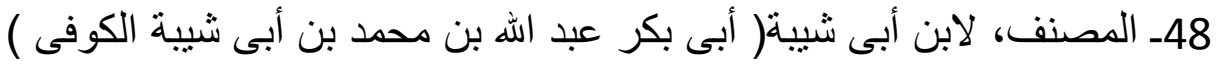

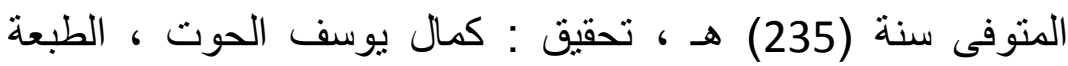

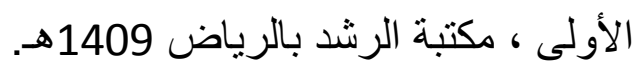

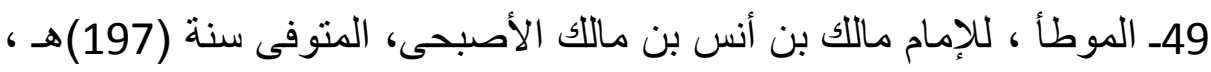

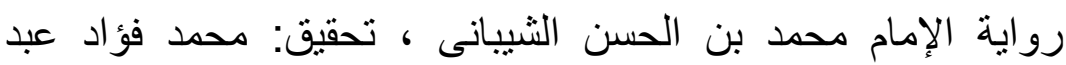

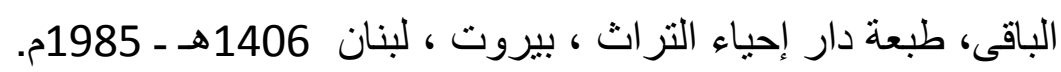

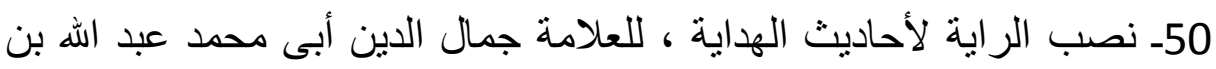

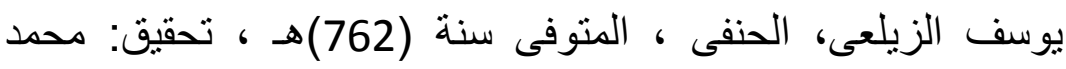

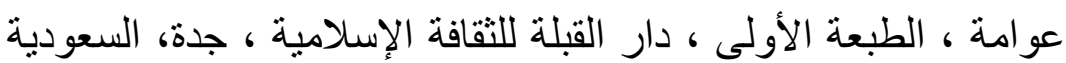

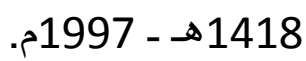




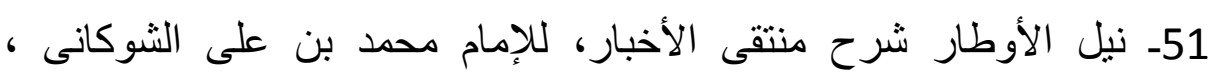

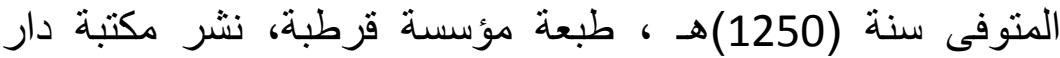

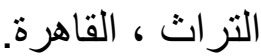

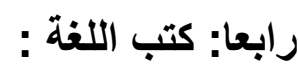

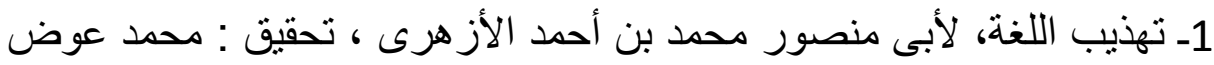

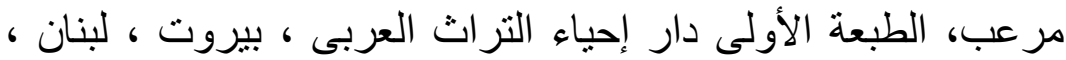

2001

2- القاموس المحيط ، لمجد الدين محمد بن يعقوب الفيروز أبادى الثيرازى،

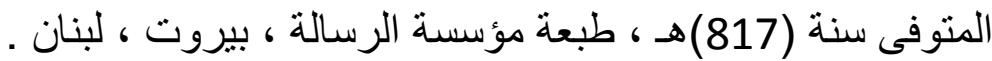

3ـ لسان العرب ، لمحمد بن مكرم بن منظور الإفريقى المصرى، المتوفى سنة

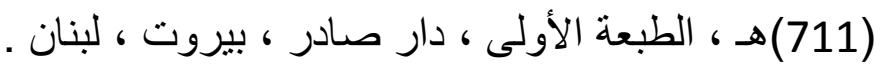

4ـ مختار الصحاح، لمحمد بن أبى بكر بن عبد القادر الرازى ، تحقيق : محمود

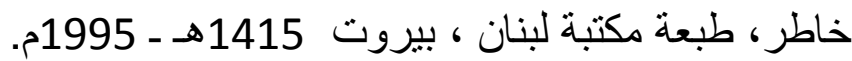

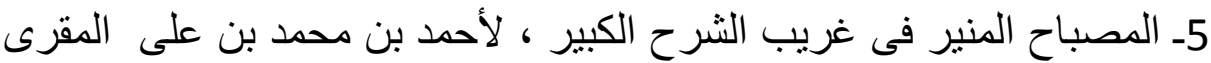

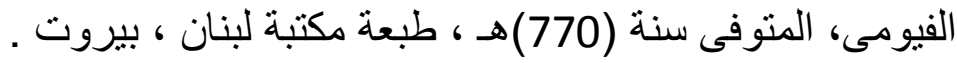

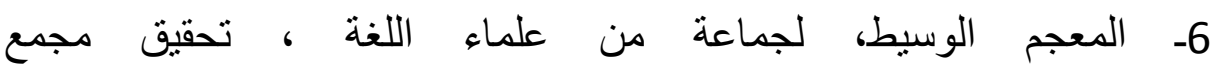
اللغة العربية ، نشر دار الدعوة ، القاهرة.

خامسا : كتب أصول الفقه :

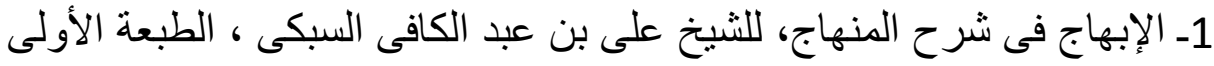

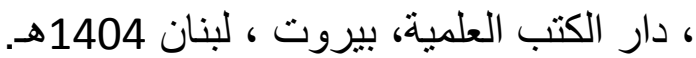

2- إرشاد الفحول إلى تحقيق الحق من علم الأصول، للشيخ محمد بن على بن

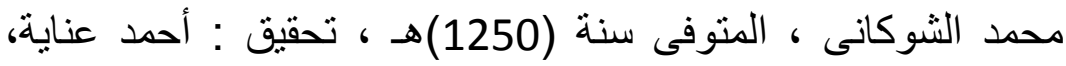

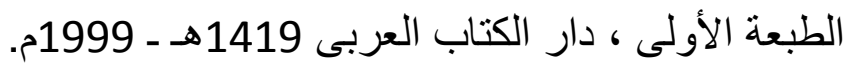


3- البحر المحبط فى أصول الفقه ، لبدر الدين محمد بن بهادر بن عبد الله

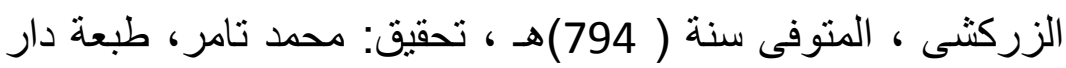

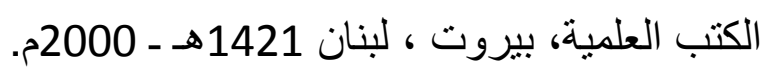

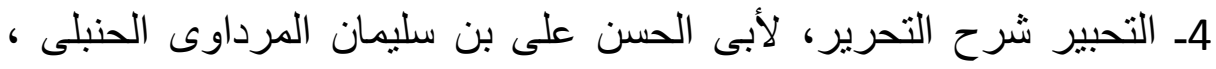

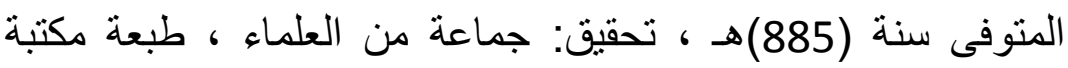

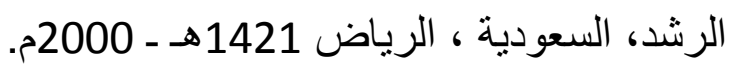

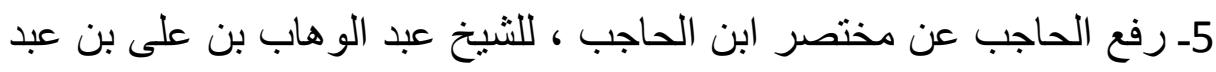

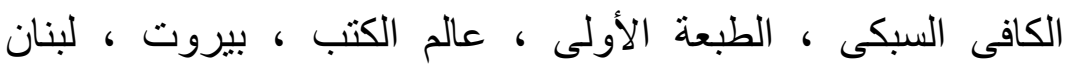

$$
\text { 1419هـ - 1999م. }
$$

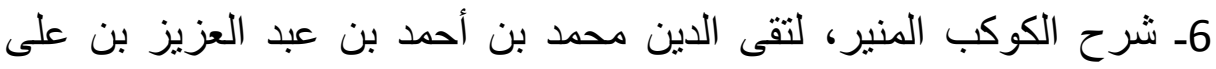

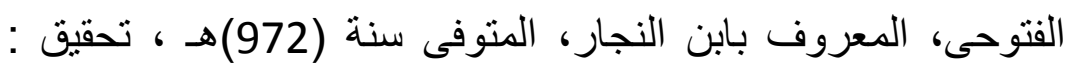

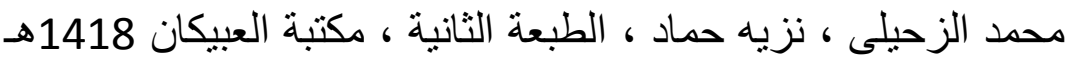

$$
\text { 1997 - م⿳⺈ - }
$$

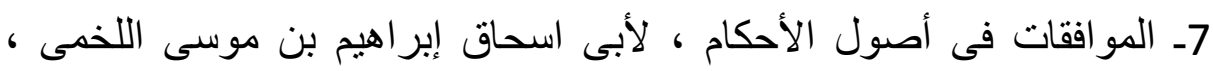

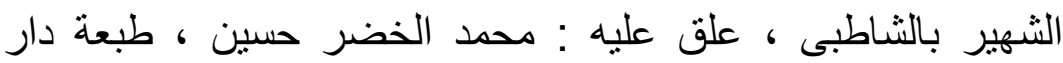
الفكر.

8- نهاية السول ، للإمام جمال الدين بن عبد الرحيم بن الحسن الإسنوى،

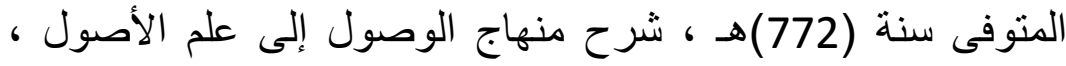

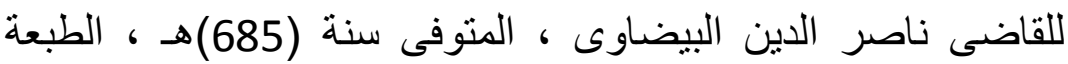
الأولى، دار الكتب العلمية ، بيروت ، لبنان ، 1420هـ ـ 1999 1920م. 


\section{سادسا : كتب المذاهب الفقهية

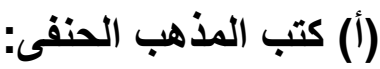

1- الاشباه و النظائر ، للإمام زين العابدين بن إبراهيم بن نجيم، المتوفى سنة

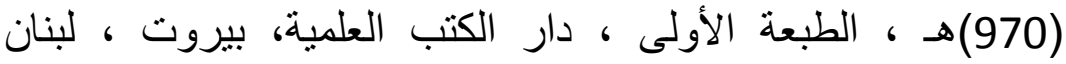

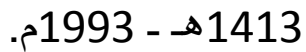

2- البحر الرائق شرح كنز الدقائق ، لابن نجيم، تقدم ذكره، وتكملته لمحمد بن

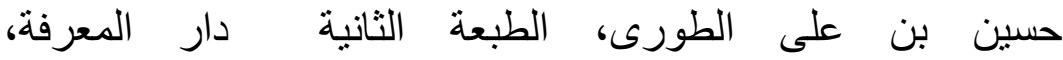

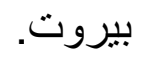

3- بدائع الصنائع فى ترتيب الثرائع ، للإمام علاء الدين أبى بكر بن مسعود

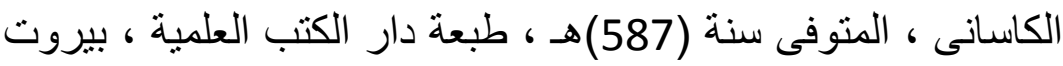

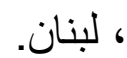

4- تبيين الحقائق شرح كنز الدقائق ، لفخر الدين عثمان بن على الزيلعى ،

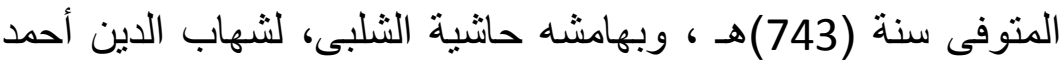

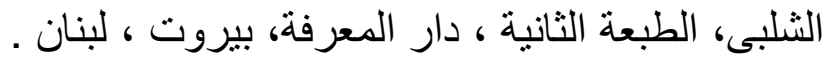
5- حاثية سعد الله بن عيسى المفتى، الثهير بسعدى جلبى، المتوفى سنة

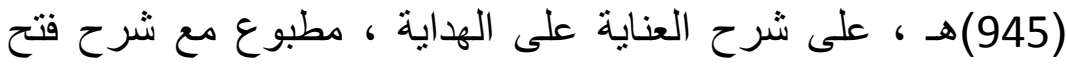
القدير، طبعة دار الكتب العلمية، بيروت ، لبنان.

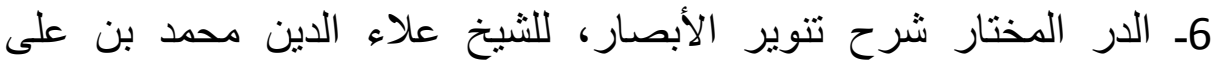

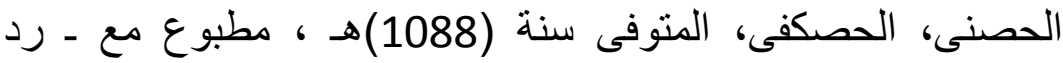
المحتار لابن عابدين، طبعة دار الفكر، 1412هـ ـ 1992م.

7- رد المحتار على الدر المختار شرح تنوير الأبصار، للعلامة محمد أمين بن

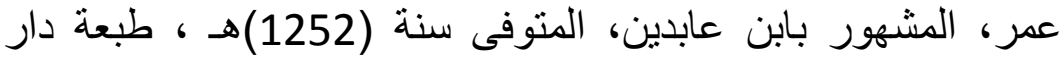

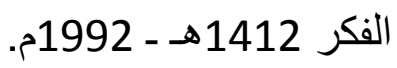

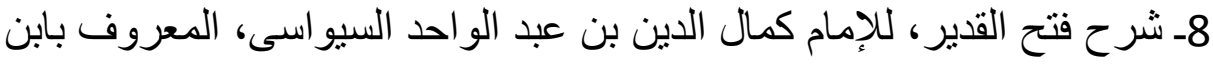

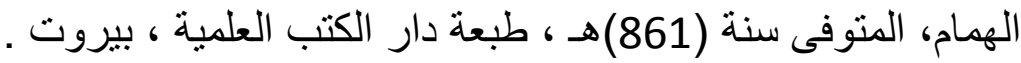


9ـ العناية على الهداية ، لأكمل الدين محمد بن محمو د البابرتى، المتوفى سنة

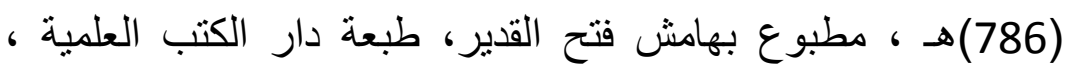

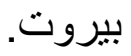

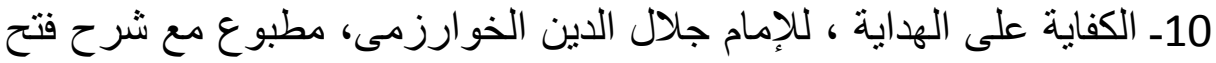
القدير، طبعةدار الكتب العلمية، بيروت ، لبنام البنان.

11- كنز الدقائق ، للإمام عبد الله بن أحمد النسفى ، المتوفى سنة (710)هـ ،

$$
\text { مطبوع مع شروحه. }
$$

12- المبسوط ، للإمام شمس الدين محمد بن أحمد بن أبى سهل السرخسى ،

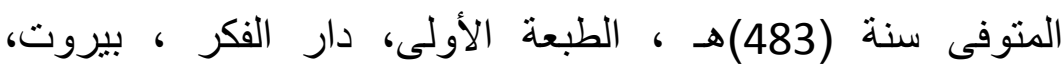

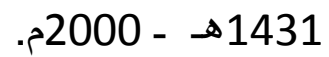

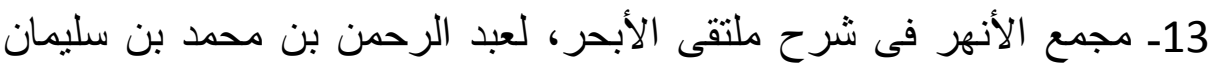

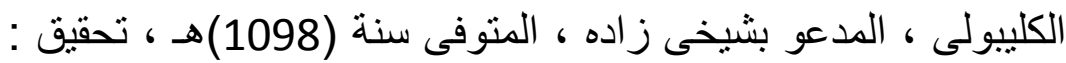
خليل عمران منصور ، طبعة دار الكتب العلمية، بيروت ، لبنان

$$
\text { 1419هـ - 1998م. }
$$

14- الهداية شرح بداية المبندى ، لثيخ الإسلام برهان الدين على بن أبى بكر

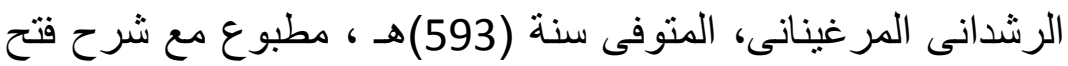

القدير ، طبعة دار الكتب العلمية ، بيروت ، لبنان.

$$
\text { (ب) كتب المذهب المالكى : (ب) }
$$

1- الاستذكار لمذاهب علماء الأمصار ، لأبى عمر يوسف بن محمد بن عبد البر

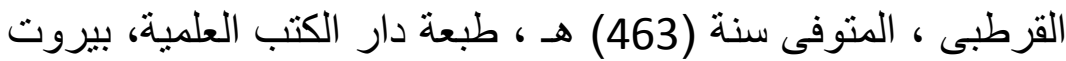

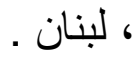

2- إعداد المهج للاستفادة من المنهج فى قو اعد الفقه المالكى، للشيخ محمد بن مختار الشنقيطى ، طبعة دولة قطر سنة 1403هـ. 
3- أقرب المسالك إلى مذهب الإمام مالك، لأبى البركات أحمد بن محمد بن أحمد

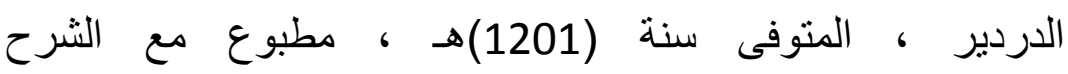
الصغير ، طبعة المعاهد الأزهرية.

4- بداية المجتهد ونهاية المقتصد، لمحمد بن أحمد بن محمد بن رشد (الحفيد)

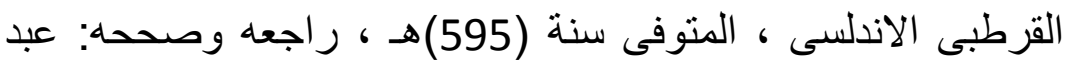
الحليم محمد عبد الحليم ، عبد الرحمن حسن محمود ، مطبعة حسان ، القاهرة.

5- البيان و التحصيل و الثرح و التوجيه لمسائل المستخرجة ، لأبى الوليد محمد

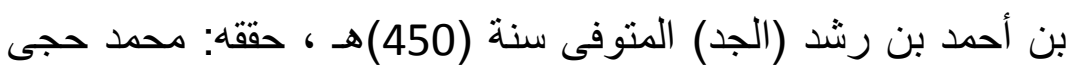

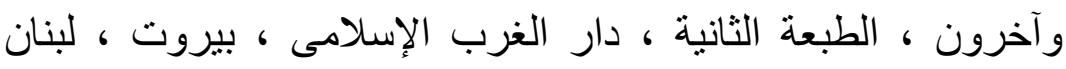

$$
\text { 1408هـ - 1998م. }
$$

6- التاج و الإكليل، لأبى عبد الله محمد بن يوسف بن أبى القاسم العبدرى ،

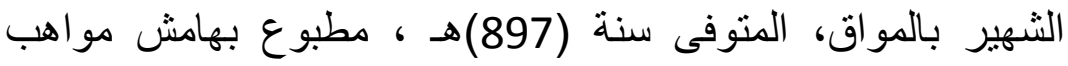

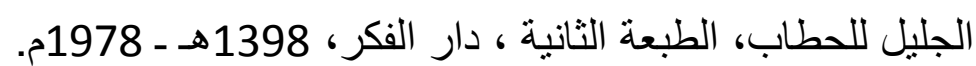

7- التلقين فى الفقه المالكى، للقاضى أبى محمد عبد الوهاب بن على بن نصر البغدادى ، تحقيق:محمد ثالث سعيد الغانى، طبعة دار الفكر ، بيروت

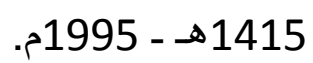

8- التمهيد لما فى الموطأ من المعانى والأسانيد ، لابن عبد البر ، تحقيق : مصطفى العلوى ، محمد البكرى ، نشر مؤسسة الرسالة، بيروت.

9- جامع الأمهات ، للثيخ جمال الدين بن عمر بن الحاجب ، المتوفى سنة

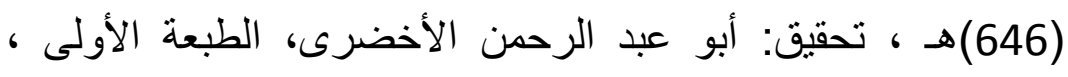
اليمامة، دمشق ، بيروت هـ

10- حاثية الدسوقى على الثرح الكبير، للثيخ محمد بن أحمد بن عرفة الدسوقى ، المتوفى سنة (1230)هـ ، مطبوع مع الثرح الثر الكبير للاردير ، طبعة دار إحياء الكتب العربية، عيسى البابى الحلبى. 
11- حاثية العدوى على الخرشى ، للثيخ على الصعيدى العدوى، المتوفى سنة

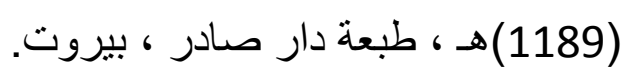

12- حاثية العدوى على كفاية الطالب الربانى، طبعة مصطفى البابى الحلبى

$$
\text { 1357هـ - 1938م }
$$

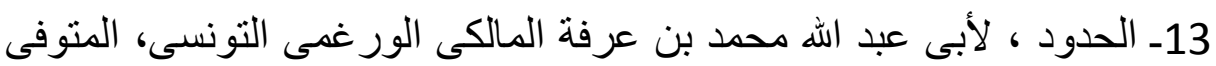

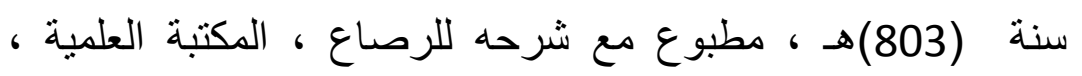
تونس.

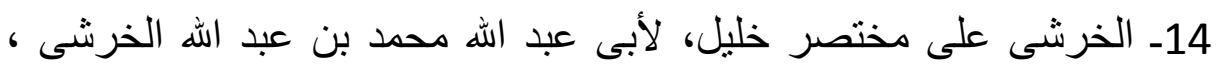

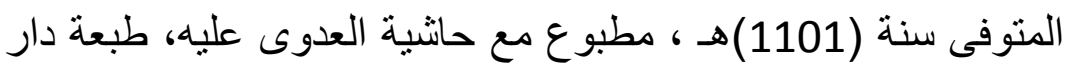

$$
\text { صادر ، بيروت . }
$$

15- الذخيرة ، للقر افى ، تحقيق: محمد حجى ، طبعة دار الغرب الإسلامى ،

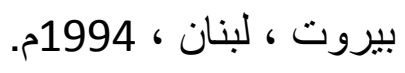

16- الرسالة، لأبى محمد عبد الله بن ابى زيد القيروانى، المتوفى سنة (386)هـ

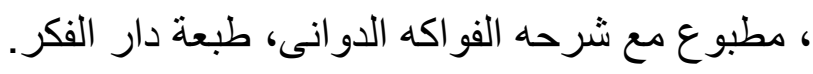

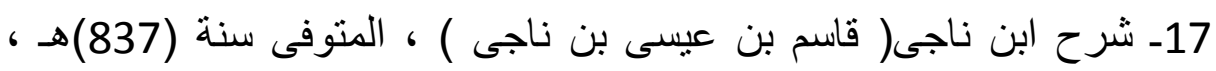

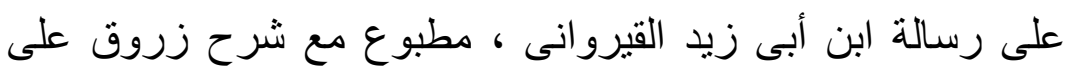

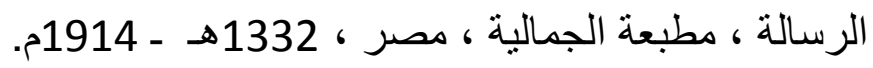

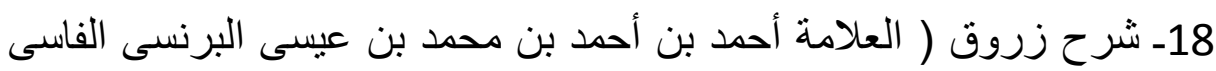

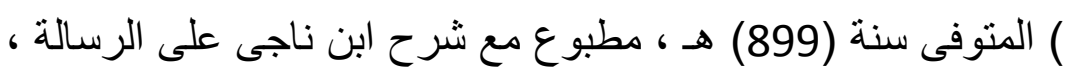

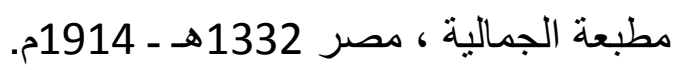

19- الثرح الصغير على أقرب المسالك إلى مذهب الإمام ماللك ، لأبى البركات

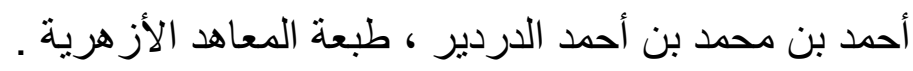

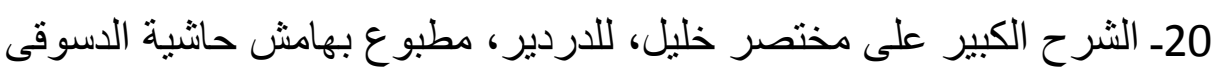
عليه، طبعة دار إحياء الكتب العربية، عيسى البابى الحلبى. لإئ. 


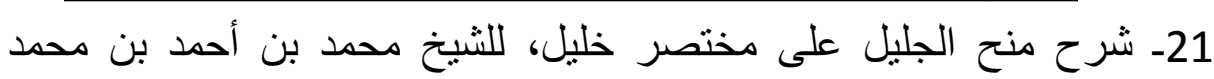

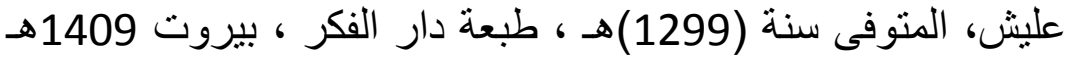

1989 -

22- الفواكه الدوانى على رسالة القيروانى، للشيخ أحمد بن غنيم بن سالم بن

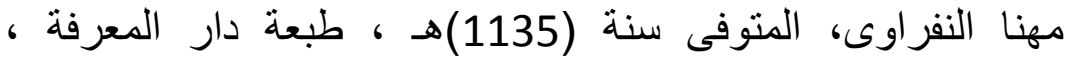

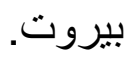

23ـ القوانين الفقهية، لأبى عبد الله محمد بن أحمد بن محمد بن جزى الكلبى

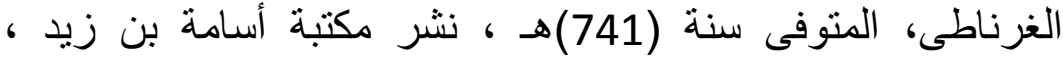

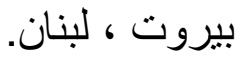

24- الكافى فى فقه أهل المدينة، لأبى عمر يوسف بن عبد الله بن عبد البر، المنوفى سنة (463)هـ ، الطبعة الأولى ، دار الكتب العلمية، بيروت ،

$$
\text { لبنان. }
$$

25- كفاية الطالب الربانى لرسالة ابن أبى زيد القيروانى، للإمام أبى الحسن

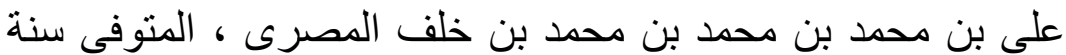

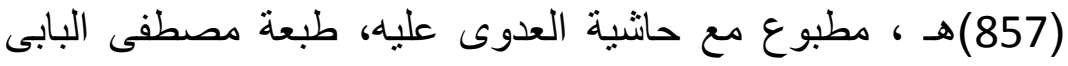

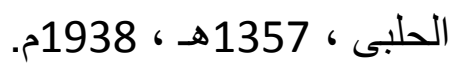

26- المختصر ، للشيخ خليل بن إسحاق بن موسى الجندى ، المتوفى سنة (776)هـ ، مطبوع مع شروحه السابقة.

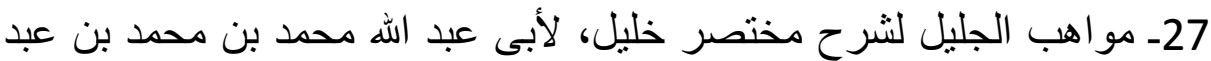
الرحمن المغربى، المعروف بالحطاب، المتوفى سنة (954)هـ ، وبهامشه التاج و الإكليل للمواق، الطبعة الثانية ، دار الفكر ، 1398هـ الفهرفي 1978 (ج) كتب المذهب الثافعى : (ج)

1- أسنى المطالب شرح روض الطالب، للثيخ زكريا الأنصارى، تحقيق : د.

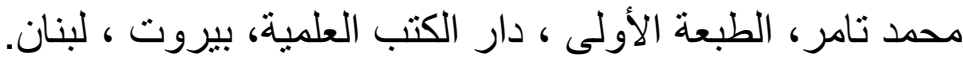




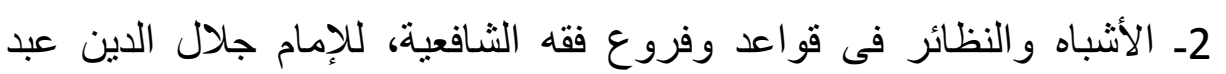

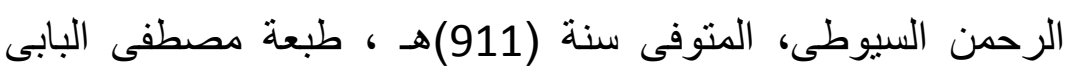
الحلبى ، طبعة أخيرة 1378هـ - 1959م. 1959.

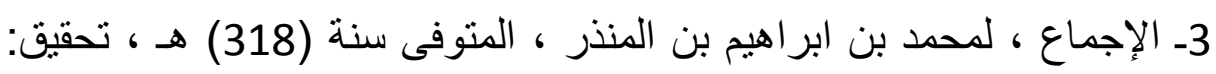

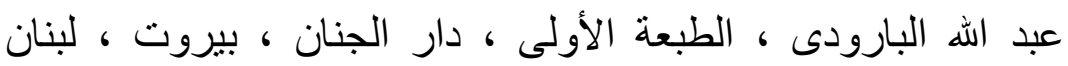

$$
\text { 1406هـ - 1986م. }
$$

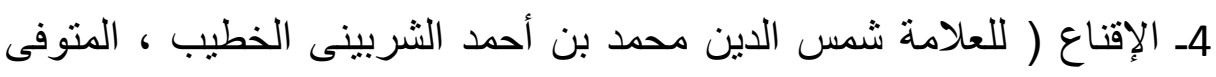

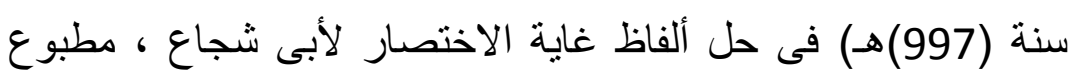

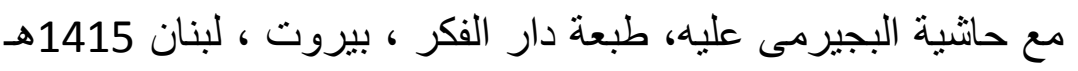

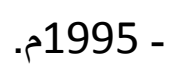

5- الأم ، للإمام الثافعى، طبعة دار المعرفة، بيروت ، لبنان 1292هـ.

6- حاثية بجيرمى على الخطيب، المسماة بتحفة الحيبب على شرح الخطيب ،

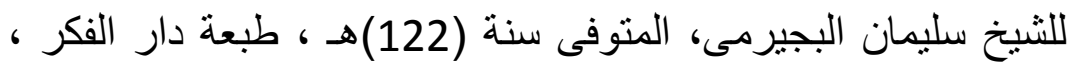

$$
\text { بيروت 1415هـ - 1995م. }
$$

7- حاثيتا شهاب الدين القليوبى والثيخ عميرة، على شرح العلامة جلال الدين

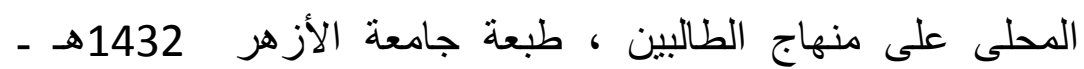
2011

8- حاثية الثيخ سليمان الجمل على شرح المنهج،للثيخ زكريا الأنصارى، طبعة دار الفكر، بيروت ، لبنان لبنان.

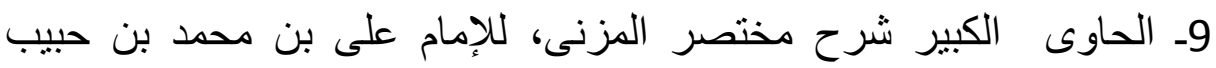

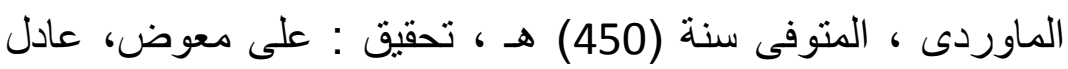

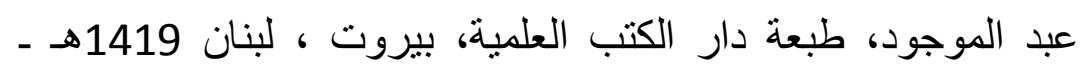


10- روضة الطالبين، للإمام أبى زكريا يحيى بن شرف النووى، المتوفى سنة

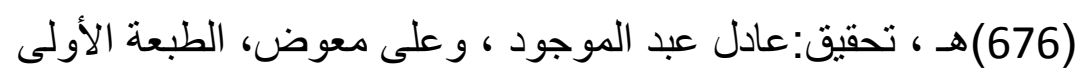
، دار الكتب العلمية، بيروت ، هاع، 1412هـ - 1992م.

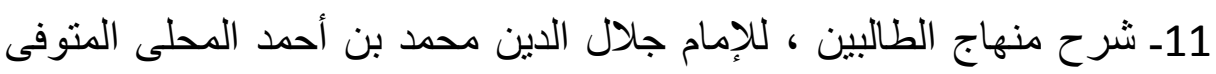
سنة (864)هـ ، مطبوع مع حاثيتى قليوبى وعميرة عليه، طبعة

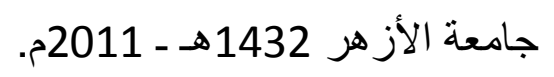

12- فتح العزيز شرح الوجيز، لأبى القاسم عبد الكريم بن محمد الرافعى، الـه المتوفى سنة (623)هـ ، مطبوع مع المجموع للنووى، طبعة دار الفكر، بيروت ، لبنان.

13- فتح الوهاب بشرح منهج الطلاب، لشيخ الإسلام زكريا الأنصارى ، طبعة عيسى البابى الحلبى وشركاه.

14- قو اعد الأحكام فى مصالح الأنام، للإمام أبى محمد عز الدين عبد العزيز بن عبد السحام، المتوفى سنة (660) هـ ، طبعة مؤسسة الريان ، بيروت،

$$
\text { لبنان 1410 14هـ - 1990م. }
$$

15ـ المجموع شرح المهذب، للإمام أبى زكريا يحيى بن شرف النووى، المتوفى (هرى

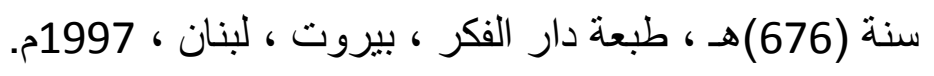

16- مختصر المزنى، للإمام أبى إبراهيم إسماعيل بن يحيى المزنى ، المتوفى سنة (264)هـ ، مطبوع مع الحاوى الكبير للماوردى ، الطبعة الأولى الكي

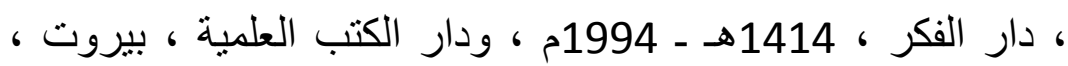

$$
\text { لبنان 1419 هـ - 1999م. }
$$

17- مغنى المحتاج إلى معرفة معانى ألفاظ المنهاج، للثيخ محمد الثربينى الخطيب :، المتوفى سنى (997)هـ ، طبعة دار الفكر، بيروت ، معنى 1415هـ - 1995م. - 195 


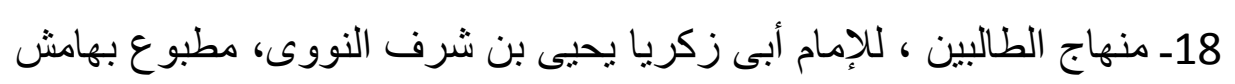

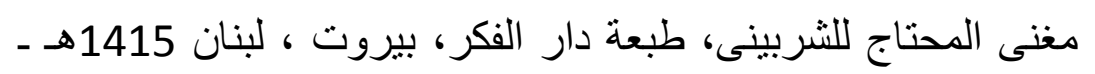
1995م.

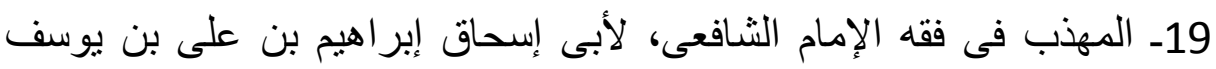

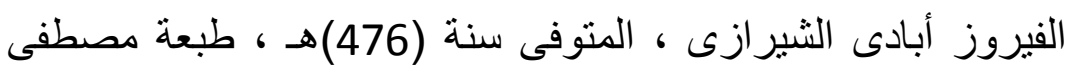

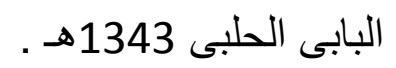

20- نهاية المحتاج إلى شرح المنهاج، للإمام شمس الدين محمد بن أحمد بن

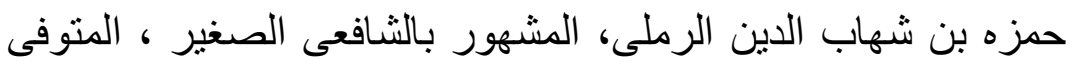

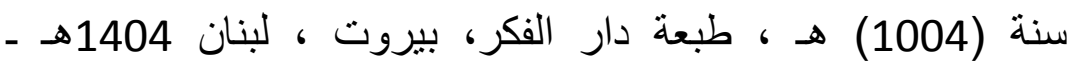
1984م.

21- نهاية المطلب فى دراية المذهب ، لإمام الحرمين عبد الملك بن عبد الله بن

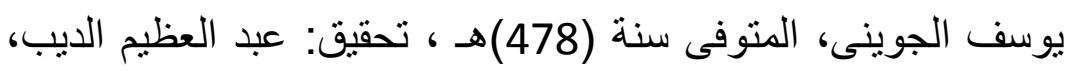
الطبعة الأولى ، دار المنهاج 1428هـ ـ 2007م. لمنئ.

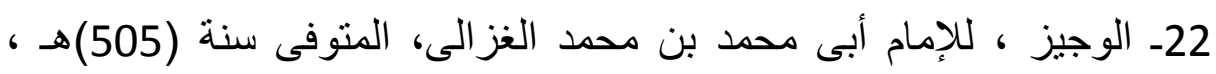

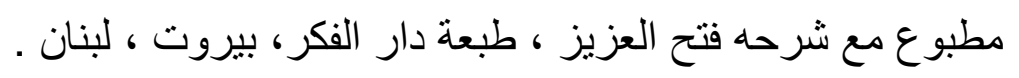

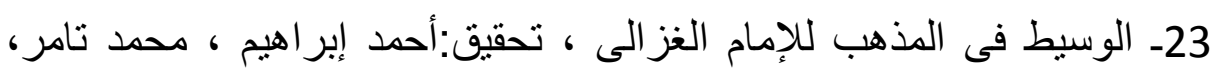

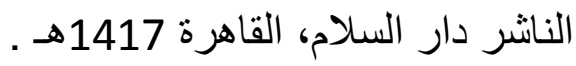

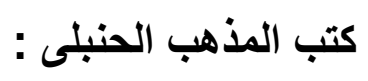

1- الآداب الثرعية و المنح المرعية، لبر هان الدين بن محمد بن عبد الله بن مفلح ، المتوفى سنة (884هـ) ، طبعة مؤسسة قرطبة.

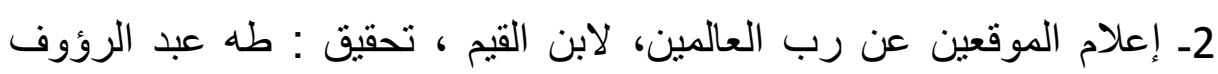

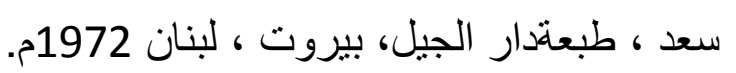


3 - الاقناع ، لأبى النجا موسى بن أحمد بن موسى بن سالم الحجاوى المقدسى ،

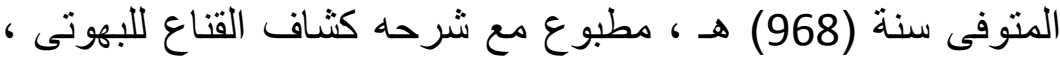

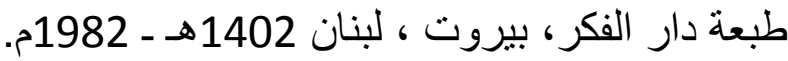

4ـ الإنصاف فى معرفة الراجح من الخلاف على مذهب الإمام أحمد بن حنبل، للثيخ علاء الدين أبى الحسن على بن سليمان المرداوى، المتوفى سنة التهاء

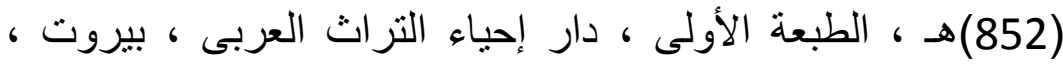
لبنان ، الطبعة الأولى 1419هـ الطعة الاولى داري

5- تحقيق المطالب بشرح روض الطالب، لأبى المنذر محمود بن محمد بن

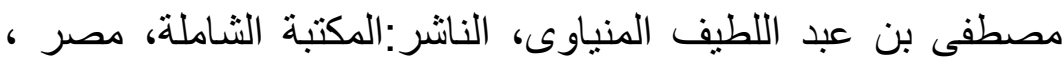

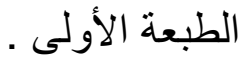

6ـ تصحيح الفروع، لأبى الحسن على بن سليمان المرداوى ، مطبوع مع الفروع لابن مفلح الآتى ذكره.

7- الروض المربع بشرح زاد المستقنع ، للشيخ منصور بن يونس بن إدريس

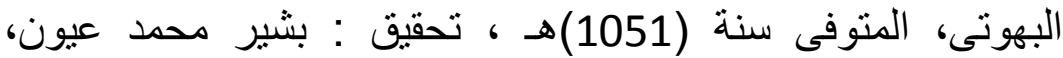
الطبعة الثانبة ، مكتبة دار البيان، دمثق ، بيروت 10514هـ 1414هـ - 1993م.

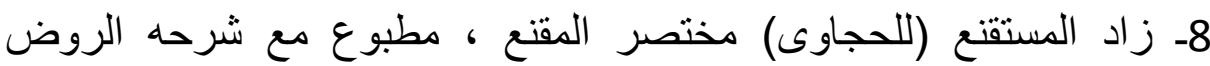

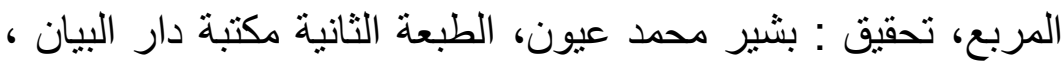

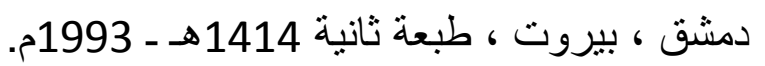

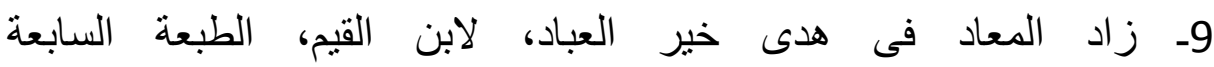
و العشرون ، مكتبة المنار الإسلامية ، الكويت ، ومؤسسة الرسالة،

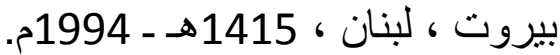

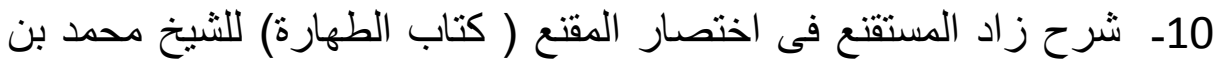

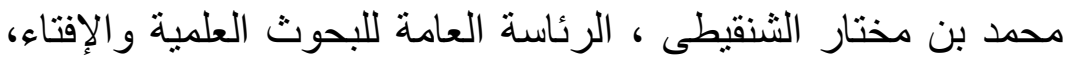

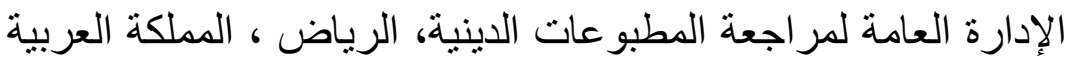
السعودية، الطبعة الأولى 1428هـ ـ 2007م. 
11- شرح الزركثى على مختصر الخرقى، لشمس الدين محمد بن عبد الله

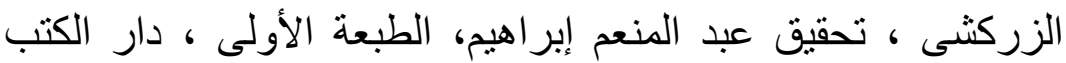

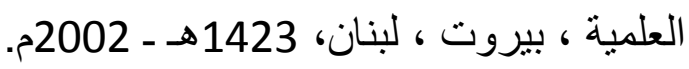

12- الثرح الكبير ، لثمس الدين عبد الرحمن بن محمد بن أحمد بن قدامة

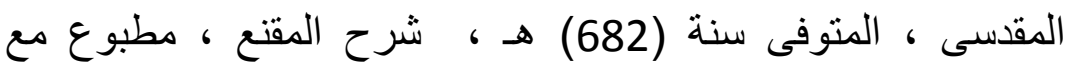
المغنى، طبعة دار الغد العربى.

13- شرح منتهى الإر ادات للبهونى، طبعة دار الفكر ، بيروت ، لبنان.

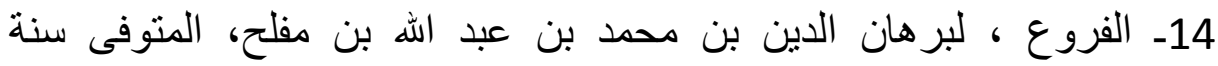

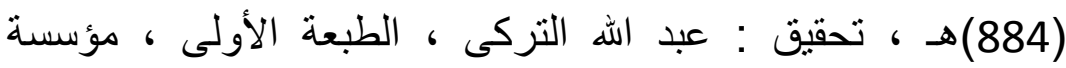

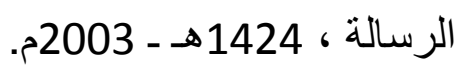

15- الكافى فى فقه الإمام أحمد بن حنبل ، لأبى محمد عبد الله بن أحمد بن محمد

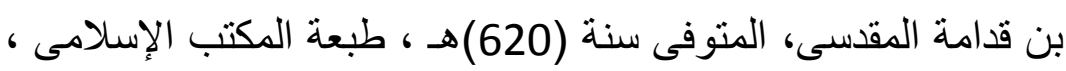

$$
\text { بيروت ، لبنان. }
$$

16- الفتاوى الكبرى، لأبى العباس أحمد بن عبد الحليم بن تيمية

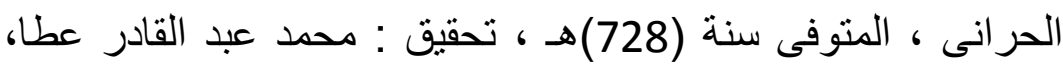

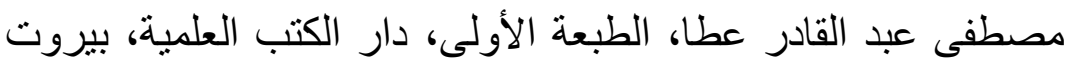

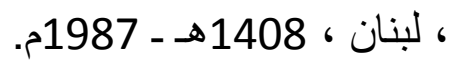

17- كتب ورسائل وفتاوى، شيخ الإسلام أحمد بن تيمية ، تحقيق: عبد الرحمن

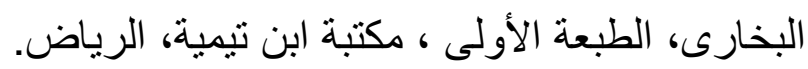

18- كثاف القناع عن متن الإقناع، للشيخ منصور بن يونس البهونى ، راجعه

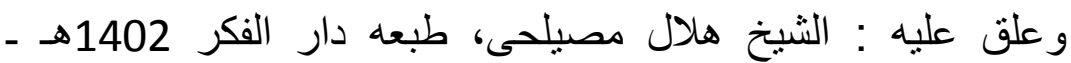




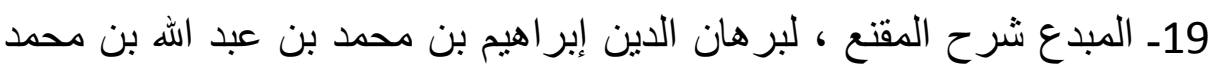

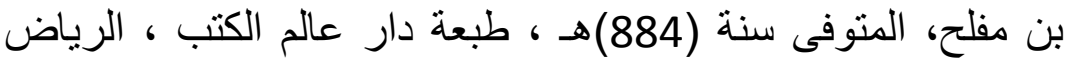

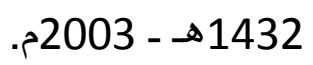

20- مختصر الخرقى ( لأبى القاسم عمر بن الحسين بن عبد الله بن أحمد الخرقى ) المنوفى سنة (334)هـ ، مطبوع مع شرحه الابه المغنى ، طبعة

$$
\text { دار الغد العربى. (القي. }
$$

21- المستدرك على مجموع الفتاوى، لثيخ الإسلام أحمد بن تيمية، جمع

وترتيب : محمد بن عبد الرحمن بن قاسم، الطبعة الأولى 1418هـ ـ.

22- مطالب أولى النهى فى شرح غاية المنتهى، للشيخ مصطفى السيوطى

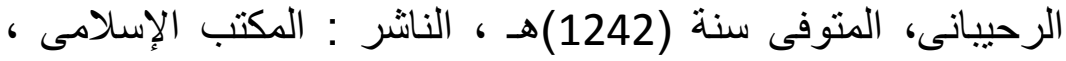

$$
\text { دمثق 1961م. }
$$

23ـ المغنى على مختصر الخرقى، لموفق الدين أبى محمد عبد الله بن أحمد بن

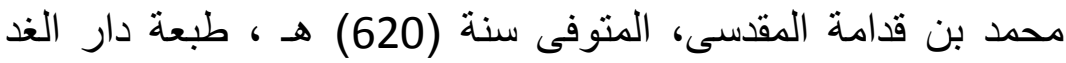

$$
\text { العربى. }
$$

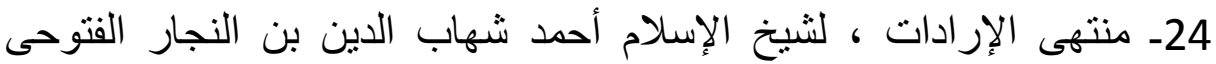

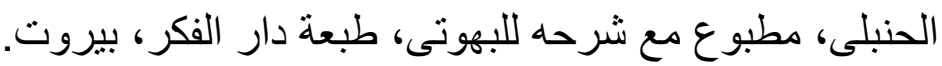

25- المنثور فى القواعد، للإمام محمد الزركثى ، تحقيق: د. تيسير محمود،

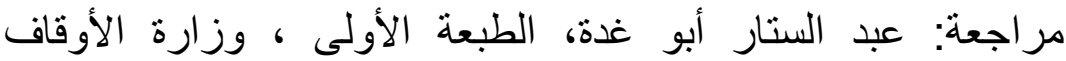

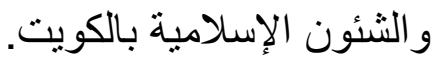

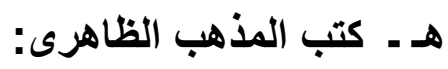

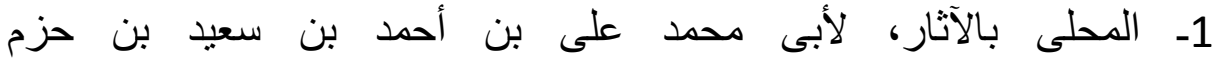

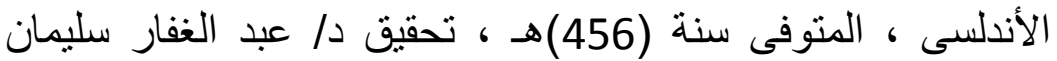
البندارى، طبعة دار الفكر، بيروت ، لبنان. 2- مر اتب الإجماع فى العبادات و المعاملات و الاعتقادات لابن حزم ، طبعة دار الكتب العلمية، بيروت ، لبنان البان. 


\section{وـ كتب مذهب الثيعة الزيدية:}

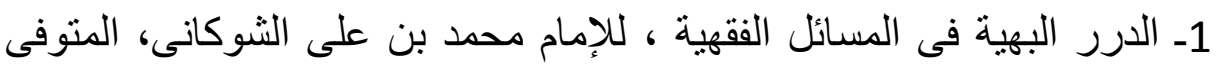
سنة (255)هـ ، مطبوع مع شرحه الروضة الندية.

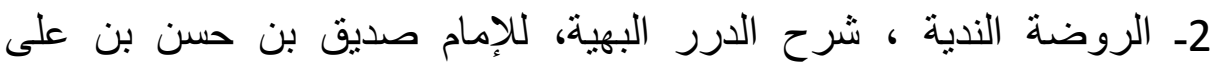

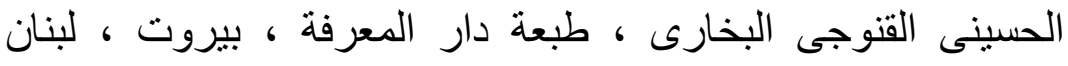
1398هـ - 1978م.

3ـ السيل الجرار المتدفق على حدائق الأزهار، للإمام الثوكانى، تحقيق: محمود

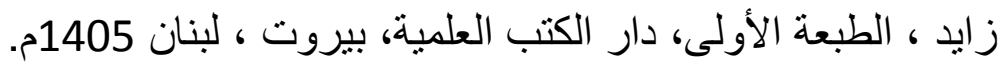

\section{سابعا: الموسوعات العلمية والمراجع والبحوث المتخصصة:}

1- استحالة النجاسات وعلاقة أحكامها باستعمال المحرم و النجس، للاكتور محمد

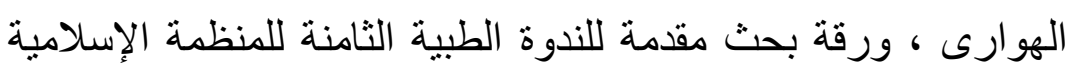

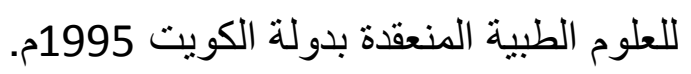

2- استخدام الدم فى الغذاء ، للاكتور سعيد سلام، ورقة بحث مقدمة للندوة الطبية التاسعة للمنظمة الإسلامية للعلوم الطبية المنعقدة بالدار البيضاء

3- استعمال مياه الصرف الصحى المعالجة للأغراض الزراعية، د. عبد الله

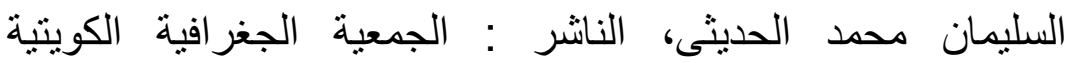

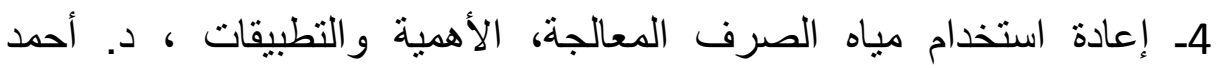

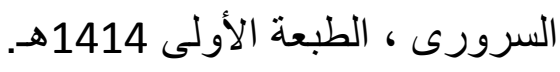

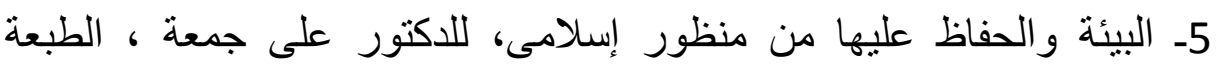

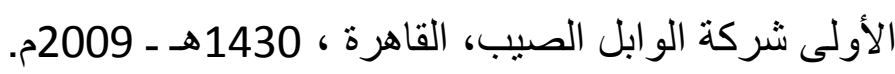
6ـ تلوث البيئة، د. شفيق يونس، الناشر: دار الفرقان ، الطبعة الأولى420 هـ . 
استحالة النجس إلى طاهر للاتثفاع به فى الفقه الإسلامى د.عبده السيد أحمد الثريف

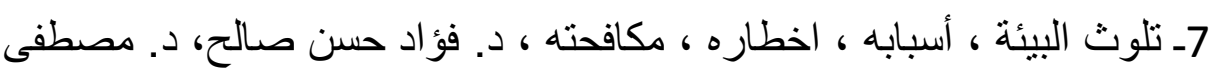

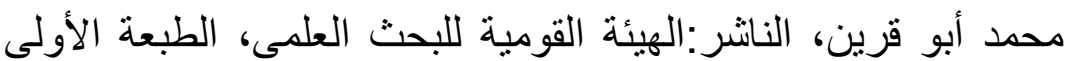

8- الطعام و الثراب بين الحلال والحرام ، للاكتور / محمد الهوارى ، بحث

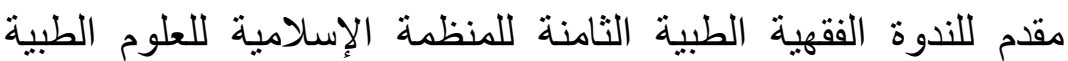
المنعقدة بالكويث ، 1995م.

9ـ المدخل إلى العلوم البيئية ، د. سامح غرابية، د. يحيى الفرحان، الناشر: دار

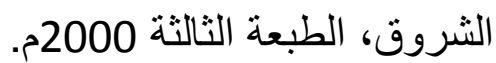

10ـ مشكلات استخدام المو اد المحرمة فى المنتجات الغذائية ، للبروفيسور محمد

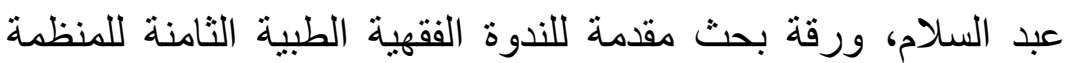

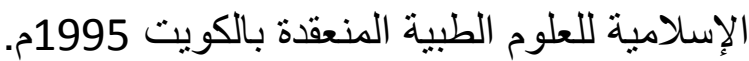

11- معالجة المياه ـ م عبد الكريم درويش ، الطبعة الأولى ، دار المعرفة ، لئه

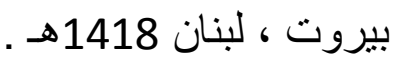

12 ـ معالجة مياه الصرف الصحى ، بحث منشور فى مجلة العلوم و التقنية ،

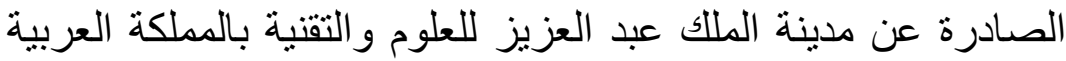

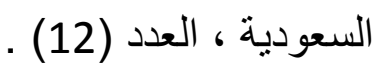

13ـ المو اد المحرمة والنجسة فى الغذاء و الدواء، د. أحمد رجائى الجندى، ورقة بحث مقدمة للندوة الطبية الثامنة للمنظمة الإسلامية للعلوم الطبية المنعقدة بدولة الكويت سنة 1995م. للنة الطنة

14ـ المو اد المحرمة و النجسة فى الغذاء و الدواء بين النظرية و التطبيق ، للاكتور نزيه حماد، الطبعة الأولى ، دار القلم، دمشق ، 1432هـ - 2011م.

15- مو اد نجسة فى الغذاء و الدواء ـ د. عبد الفتاح محمود إدريس ، الطبعة

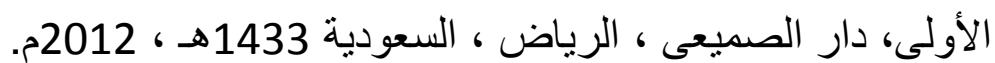




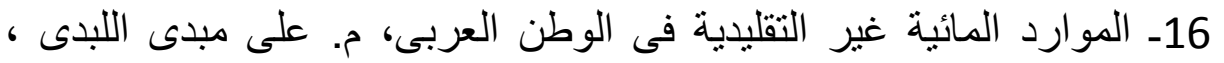

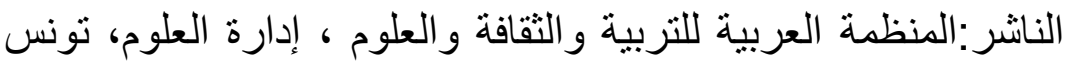

$$
\text { 1998م. }
$$

ثامنا: الرسائل العلمية:

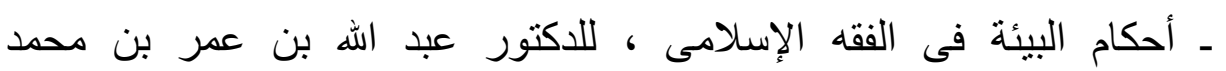

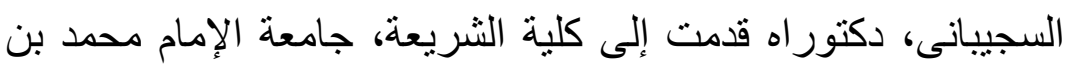

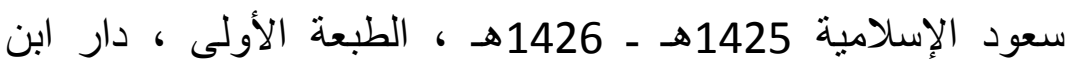
الجوزى 1429هـ - 2008م. 
فهرس الموضوعات

\begin{tabular}{|c|c|}
\hline 223 & \\
\hline 225 & خطة البحث........... \\
\hline 227 & 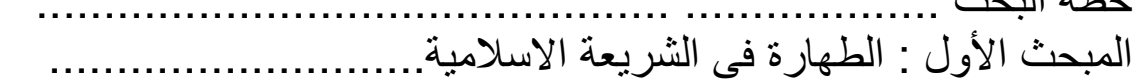 \\
\hline 228 & 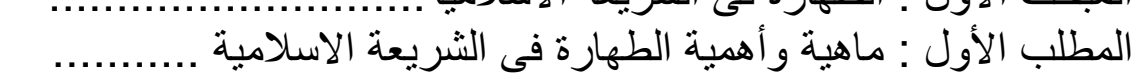 \\
\hline 228 & 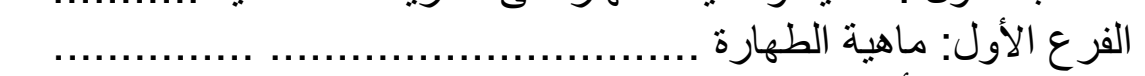 \\
\hline 233 & 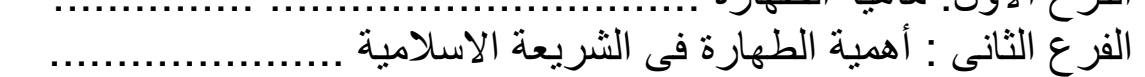 \\
\hline 237 & 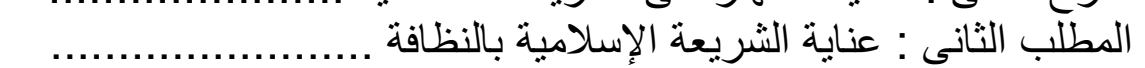 \\
\hline 246 & 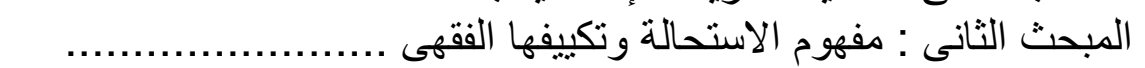 \\
\hline 246 & 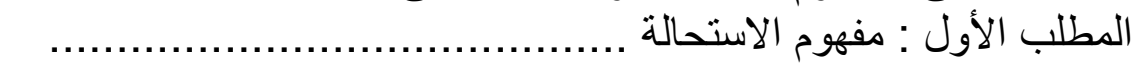 \\
\hline 248 & 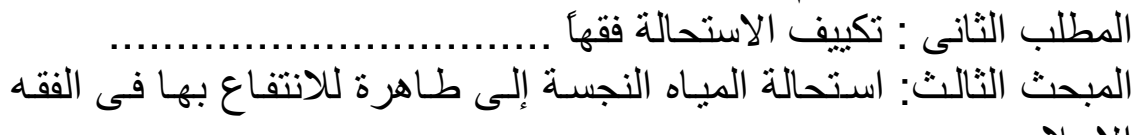 \\
\hline $\begin{array}{l}256 \\
256\end{array}$ & 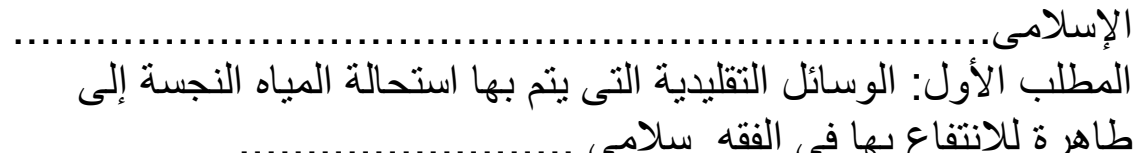 \\
\hline 260 & الفرع الأول: ( الوسيلة الأولى ) استحالة الماء النجس إلى طاهر بنفسه \\
\hline 260 & 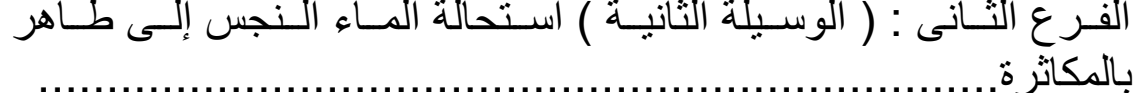 \\
\hline 264 & 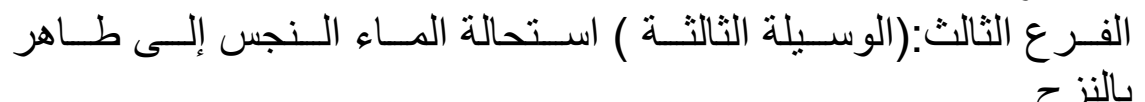 \\
\hline 271 & 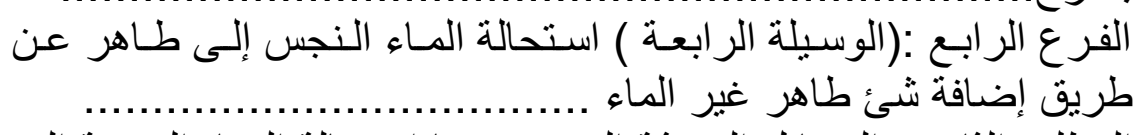 \\
\hline 275 & 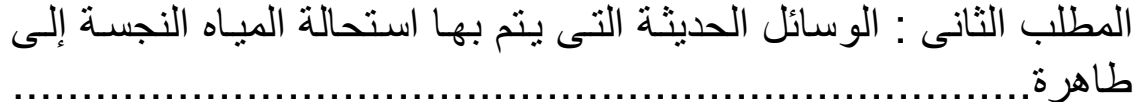 \\
\hline 280 & الحديثة فى منظور الثالث: أوجةه الانتفاع بالمياه النجسة المستحالة إلى طاهرة بالطرق \\
\hline 293 & المبحث الر ابع : استحالة الأعيان النجسة إلى طاهرة للانتفاع بها فى الفقه \\
\hline & \\
\hline & \\
\hline
\end{tabular}




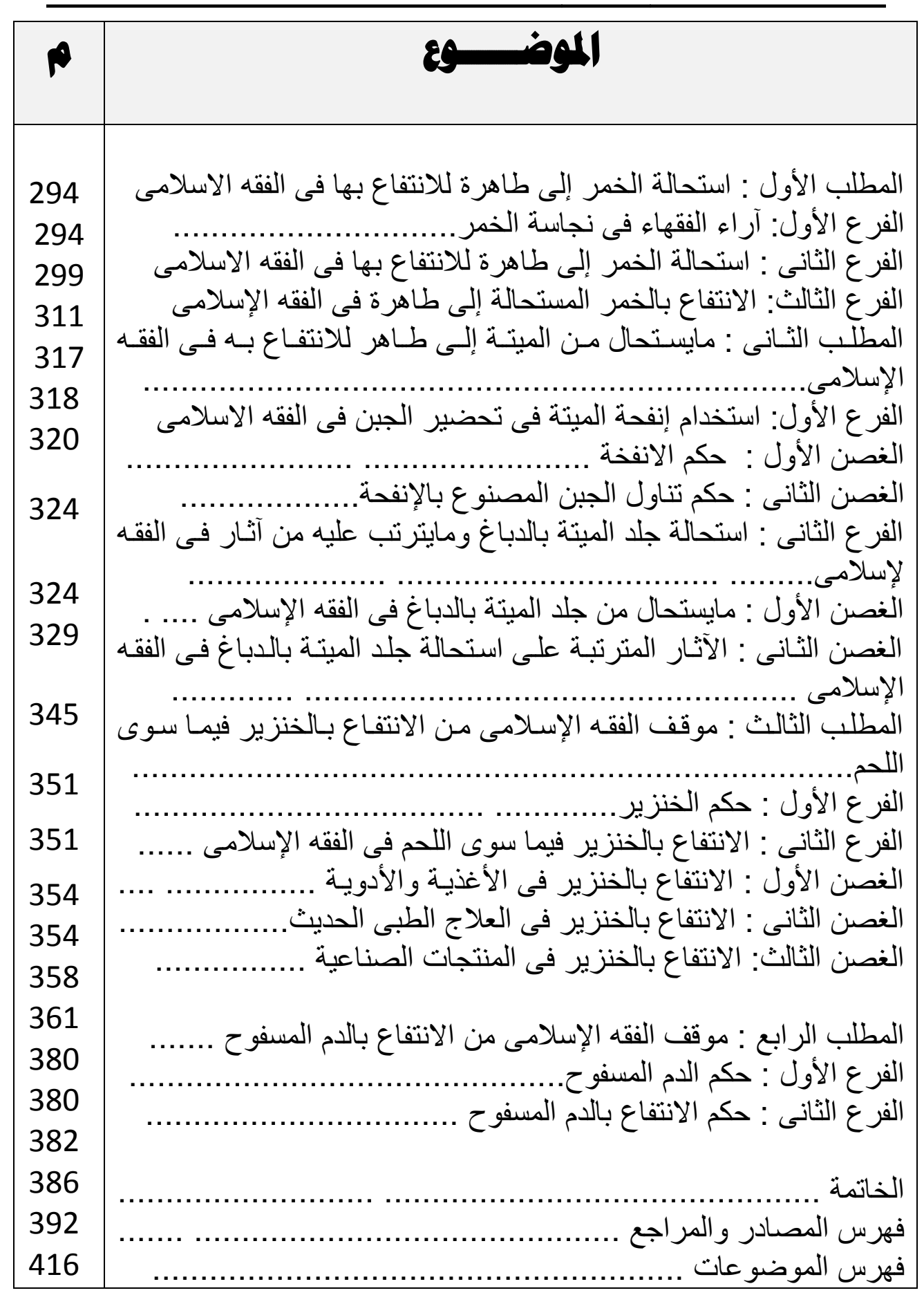


استحالة النجس إلى طاهر للاتفاع به فى الفقه الإسلاهى د.عبده السيد أحمد الثريف 